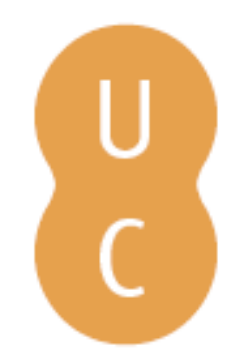

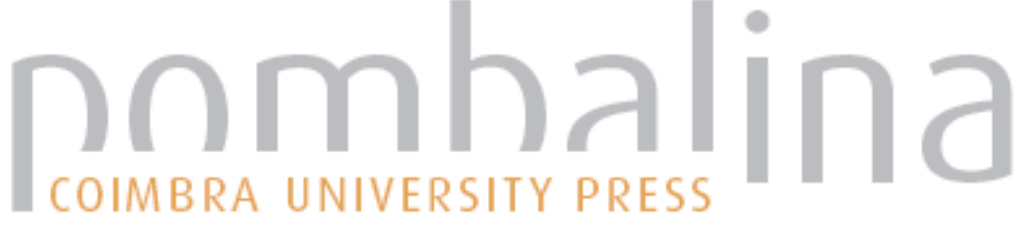

\section{Ésquilo: o primeiro dramaturgo europeu}
Autor(es): $\quad$ Silva, Maria de Fátima Sousa e
Publicado por: Imprensa da Universidade de COimbra
URL
persistente:
URI:http://hdl.handle.net/10316.2/2912
DOI:
DOI:http://dx.doi.org/10.14195/978-989-26-0379-7

Accessed : $\quad$ 26-Apr-2023 13:27:00

A navegação consulta e descarregamento dos títulos inseridos nas Bibliotecas Digitais UC Digitalis, UC Pombalina e UC Impactum, pressupõem a aceitação plena e sem reservas dos Termos e Condições de Uso destas Bibliotecas Digitais, disponíveis em https://digitalis.uc.pt/pt-pt/termos.

Conforme exposto nos referidos Termos e Condições de Uso, o descarregamento de títulos de acesso restrito requer uma licença válida de autorização devendo o utilizador aceder ao(s) documento(s) a partir de um endereço de IP da instituição detentora da supramencionada licença.

Ao utilizador é apenas permitido o descarregamento para uso pessoal, pelo que o emprego do(s) título(s) descarregado(s) para outro fim, designadamente comercial, carece de autorização do respetivo autor ou editor da obra.

Na medida em que todas as obras da UC Digitalis se encontram protegidas pelo Código do Direito de Autor e Direitos Conexos e demais legislação aplicável, toda a cópia, parcial ou total, deste documento, nos casos em que é legalmente admitida, deverá conter ou fazer-se acompanhar por este aviso.

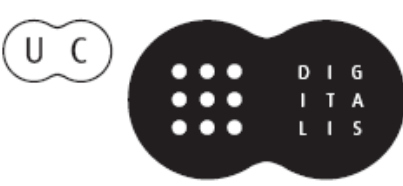


MARIA DE FÁTIMA DE SOUSA E SILVA

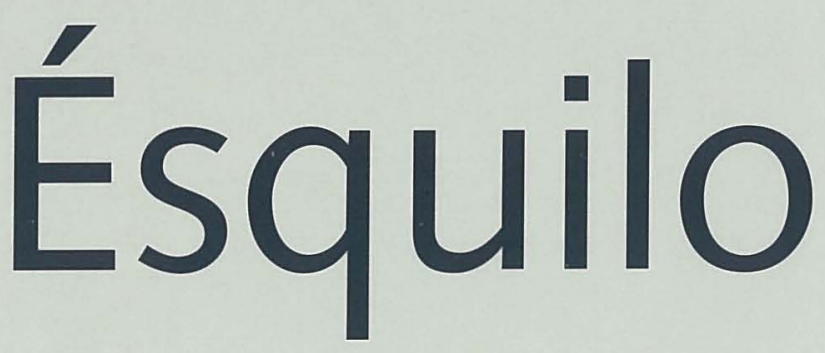

O primeiro dramaturgo europeu 
(Página deixada propositadamente em branco) 
MARIA DE FÁTIMA DE SOUSA E SILVA

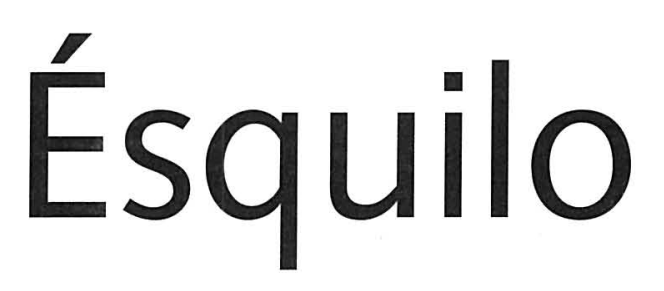

O primeiro
dramaturgo europeu 
COORDENAÇÃO EDITORIAL

Imprensa da Universidade de Coimbra

\section{CONCEPÇÃo GrÁfICA}

António Barros

PAGINAÇÃO

SerSilito - Maia

EXECUÇÃO GRÁFICA

SerSilito - Maia

ISBN

$972-8704-61-5$

DEPÓsITO LEGAL

234729/05

(C) Outubro 2005, Imprensa da Universidade de Coimbra 


\section{ÍNDICE}

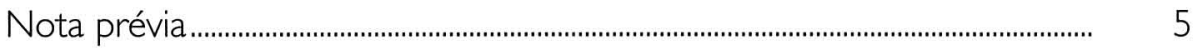

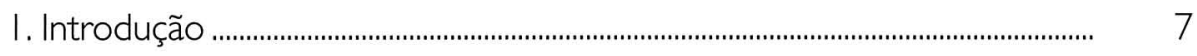

2. Coro

Coros de mulheres........................................................................................................ 17

Coéforas - o ritual fúnebre............................................................................... 17

Coros de suplicantes .......................................................................................... 18

Coros de velhos ................................................................................................................. 28

Coros de divindades............................................................................................................. $\quad 40$

3. Personagens

A expressão do transcendente em cena .................................................................... 5 I

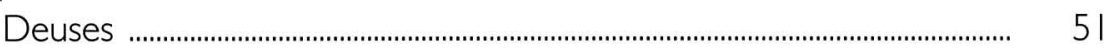

Possuídos pelos deuses ................................................................................. $\quad 66$

Fantasmas ......................................................................................................

Os homens...................................................................................................................... 87

Imagem do poder - o soberano ................................................................... 87

A mulher no poder .............................................................................................. 108

Figuras menores............................................................................................. 119

O Vigia............................................................................................................. 120

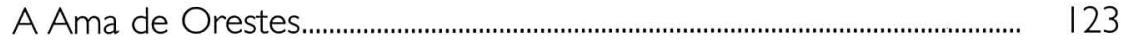

Os bárbaros ........................................................................................................ 125

4. Estratégias teatrais

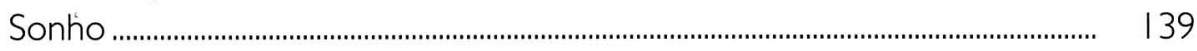

Silêncio ................................................................................................................... $\mid$

Reconhecimento ...................................................................................................... 150

Morte ….............................................................................................................. $\mid 54$

5.Ésquilo autor de dramas satíricos .................................................................. 167

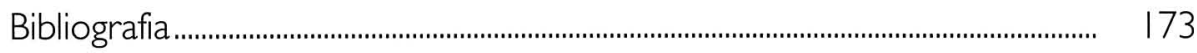


(Página deixada propositadamente em branco) 


\section{Nota prévia}

A reflexão que propomos sobre o teatro de Ésquilo, sem escamotear alguns dos problemas interpretativos mais relevantes na sua produção, é sobretudo a que merece um mestre de cena. Coros e personagens, como também recursos dramáticos, são avaliados na perspectiva técnica que consagrou Ésquilo como o detentor incontornável do trono de honra que distingue, para a eternidade, a tragédia ateniense.

Este texto foi concebido para figurar, como o capítulo dedicado a Ésquilo, na História do Teatro que as Éditions Champion programam para breve, sob a coordenação, no que respeita ao teatro grego, do Professor Pascal Thiercy, responsável também pelo Departamento de Estudos Gregos da Universidade de Brest. À amável autorização das Éditions Champion, como do coordenador do projecto, se deve a possibilidade de servir também, com a publicação autónoma deste volume, um público especificamente português, onde se incluem todos aqueles que fazem do teatro um objectivo e uma paixão. Por esta generosidade aqui deixo expresso o meu reconhecimento.

Igualmente grata me dirijo ainda à Imprensa da Universidade de Coimbra e ao seu Director, o Professor Doutor Fernando Regateiro, por ter entendido integrar, sem reservas ou adiamentos, este volume num projecto editorial, com que vem servindo, de uma forma honrosa e distinta, o nome da Instituição a que pertence. Que este título cumpra, enfim, a missão que o inspirou, de informar, mas sobretudo de estimular curiosidades e interesses por aquilo que, na existência humana, são referências eternas. 
(Página deixada propositadamente em branco) 


\section{INTRODUÇÃO}

Ésquilo, como em geral os grandes dramaturgos que marcam etapas decisivas na história do teatro, não se limitou a ser autor de textos, mesmo sendo esse já por si um mérito destacado. A sua tarefa de criador foi muito mais além: produzir e ensaiar, supervisionar todas as tarefas, do movimento de cena à dicção, gestos, cenários, adereços, música e coreografia, ou mesmo participar na representação por dentro na qualidade de actor, constituíram também atributos seus no objectivo final da execução de uma acção (drama) e na produção de um espectáculo (theatron). Para além de impressionar, à distância, um leitor, o seu propósito mais directo e imediato foi atingir uma audiência, pela mente e pelos sentidos. Toda uma techne, para além da capacidade poética, se impôs, dentro desta perspectiva, como um traço distintivo da criação dramática.

Nascido em ano próximo de 520 a. C., a sua carreira de dramaturgo inicia-se nos primeiros anos do séc. $\vee(499$ a. C.) e ao longo de quase meio século de actividade vai acumulando seis dezenas de tragédias e uma vintena de dramas satíricos. Devemos a Ésquilo aquela que é a primeira peça trágica conservada da Antiguidade, os Persas, apresentados em 472 a. C. A tragédia com que este êxito esquiliano conviveu era já um género desenvolvido e sofisticado, a que Ésquilo veio trazer o contributo próprio de quem, antes ainda do fim do século, se viria a consagrar como um clássico, o detentor por muito tempo incontroverso do trono de honra da tragédia, na versão famosa de Rãs de Aristófanes. Para este ascendente difícil de derrubar contribuíram qualidades de excelência, que criaram, membro a membro, o primeiro grande dramaturgo grego: uma inexcedível finura e criatividade poética, uma noção clara da harmonia a obter dos diversos recursos do teatro, e um sentido apurado do que são as aspirações, os temores e as limitações da vida humana. Com este conjunto de méritos, Ésquilo conquistava, de uma só vez, um prémio 
de excelência, concedido pelos seus contemporâneos, e de perenidade, atribuído sem cansaço pelos vindouros.

Utilizaremos como um guia para a avaliação do teatro esquiliano aquele que foi um dos seus primeiros críticos, accionando critérios que constituíam a chave de leitura do público a quem Ésquilo dedicou a sua produção. Refiro-me naturalmente a Aristófanes e ao já mencionado agôn de Rãs, que é o primeiro documento abonatório da arte paradigmática de Ésquilo. Porque contemporâneo e também ele um homem de teatro, Aristófanes detinha credenciais específicas para validar a sua avaliação, mesmo se envolvida nas linhas deformadoras de uma caricatura.

Um princípio de base estabelece o perfil do tragediógrafo. Morto há mais de 50 anos à data de Rãs, Ésquilo ocupa, sem contestação, o lugar de honra do género entre os mortos; e será preciso que Eurípides e Sófocles baixem também ao Hades para, pela primeira vez, a concorrência se tornar possível entre os que encarnaram, na opinião dos Atenienses da época clássica, o papel dos melhores na produção trágica. Mas mais do que colocar os grandes no pedestal da imortalidade, Aristófanes avaliou neles as razões da excelência. Desmontou então as estruturas de sustentação e os nervos da sensibilidade que compõem o corpo perfeito de uma criação trágica e desvendou-lhe, por dentro, os segredos do sucesso.

No que constitui uma espécie de prelúdio a este combate de poetas é feita uma caracterização global da produção de cada um dos contendores (Rãs 8|4-829). A insistência na expressão do peso, do ruído, do brilho ofuscante, de uma certa agressividade primitiva e visceral exprime as linhas de força do teatro esquiliano. A linguagem com que o poeta contextualiza a aç̧ão é de um tom empolado, sonoro e estranho, com que se harmoniza todo o resto: a preferência pelos ambientes ruidosos e violentos do combate, a grandiosidade da acção e dos gestos, o distanciamento de tudo que é vulgar e próximo. Deste conjunto de elementos resulta a que é talvez a característica mais óbvia do teatro esquiliano, uma majestade inigualável. A culminar essa impressão, Ésquilo insiste, como termo comum nas sete tragédias conservadas, num tema responsável pelo tom ético que impregna as suas peças: a justiça divina e a infalibilidade do castigo sobre os erros humanos são a chave da arquitectura dos dramas esquilianos. Face ao poder do destino, o ser humano e a sua existência interessam em função das leis superiores que sobre eles exercem a sua força, como elementos de uma ordem universal em que o homem tem de 
integrar-se. Mas a presença e a intervenção soberana do destino não aniquila a livre determinação das personagens ou a sua responsabilidade, de modo a convertê-las em simples marionetas superiormente manipuladas. $\bigcirc$ homem actua como um ser livre na construção do seu destino, mas a sua actuação independente com frequência conflui e conspira com a vontade soberana que rege o mundo. $O$ desfecho resulta então numa estranha harmonia, duramente conquistada à custa de violência e de sofrimento, entre todas as forças activas no universo, humanas e divinas. Por outro lado, este padrão temático desenvolve-se por linhas de acção que primam pela concentração e pela simplicidade. E, como toda a dispersão é posta de lado, o conflito ganha uma força máxima para que colaboram todos os movimentos, mesmo se contidos, da estrutura dramática. Em cena, o contacto entre os dois planos da acção exprime-se com aparato. Os deuses ou as forças sobrenaturais estão, de uma forma mais ou menos concreta, presentes; como eles, também os mortos se manifestam ou aparecem. Ou pelo menos, se não visíveis, a sua intervenção é patente numa multiplicidade de sonhos, presságios ou visões. Por todos estes meios, um conflito de natureza cósmica ganha contornos materiais diante dos espectadores.

À grandeza natural da produção de Ésquilo veio associar-se um refinamento e subtileza que constituíram um passo em frente no percurso de um género que se encaminhava para a perfeição. Atónitos, os espectadores, pouco afeitos ainda aos requintes da arte depois de uma fase de simplicidade quase arcaica, eram tomados de surpresa (Rãs 909-910). Para além dos temas, a proporção praticada entre os agentes convencionais da intriga - coro e actores - veio dar também ao tom geral um contributo decisivo. A imobilidade e o mutismo de uma única personagem, sentada em cena e de rosto velado, sugerem uma estratégia dramática em que Ésquilo primou (Rãs 9| |-9|3). Para além da sugestão de um número mínimo de personagens, esta referência à exploração dos famosos silêncios na abertura de uma peça tornou-se, para os críticos contemporâneos do poeta, o símbolo de um potencial emotivo em que a incapacidade de comunicação de alguém sob a pressão extrema do sofrimento contagia, de angústia e de ansiedade, o mundo em redor. Como bem comenta J. de Romilly!, 'na cena de Ésquilo é fácil de registar como a angústia e o patético estão ligados ao próprio gesto'. Com este comentário, a

\footnotetext{
I L'évolution du pathétique d'Eschyle à Euripide (Paris 196I) 16.
} 
conhecida autora insiste numa característica que parece incontroversa na produção esquiliana: a procura deliberada de efeitos espectaculares em cena. Através das suas figuras silenciosas e enigmáticas, Ésquilo desafiou os espectadores surpreendidos e de olhos fixos na sua cena; para os deixar confusos e perturbados, à espera de penetrar e de compreender uma vivência estranha à sua experiência do quotidiano.

A austeridade destas figuras estava de acordo, no entanto, com o carácter quase hierático de uma tragédia ainda pouco movimentada. A redução de personagens em número e em capacidade de acção proporcionava, em contrapartida, ao coro ocasião para longas expansões líricas encadeadas sem intervalo nem pausa (Rãs 9|4-9|5). De resto, no que se refere à competência tradicional do coro - o lirismo do seu canto e a estética da coreografia -, Aristófanes não hesita em considerar Ésquilo como um artista de excelência e sem rival (Rãs 1251-1260). Esta proporção relativa do papel amplo destinado ao coro em contraste com a interferência proporcionalmente reduzida dos actores estabelece um período dentro da evolução da tragédia, ainda próximo das suas origens. Ao abordar esta questão fundamental na concepção de um modelo trágico, a proporção e a conexão entre actores e coro, Aristófanes deixa também patentes outros aspectos fundamentais no efeito geral de uma criação. Antes de mais a ordem segundo a qual os materiais a utilizar são dispostos; a interacção entre os diversos momentos do percurso dramático tem de obedecer a uma sequência estudada com vista ao efeito de conjunto. Depois o ascendente dado ao coro, em nítida desproporção com a personagem, impede a variedade, o movimento ou a complexidade da acção. Mas esta mesma paralisia é o segredo de uma tensão profunda que, como nenhum outro dramaturgo grego, Ésquilo soube criar no seu teatro.

Só depois de valorizar os momentos de espectáculo que criam o ambiente de cada peça, Aristófanes aborda a questão do texto. Em conformidade com o aparato solene de certas figuras e cenas, a linguagem que enfim soava tinha o tom do bombástico e do incompreensível, na visão risonha da comédia (Rãs 924-926); o que alude aos neologismos, estudados e solenes, característicos do estilo poético deste autor. Mas como contributos para o mesmo exotismo invulgar que caracterizou, aos ouvidos incautos dos espectadores, a linguagem de Ésquilo, Aristófanes acrescenta estranhas e insistentes alusões geográficas, a que cenários ou personagens estrangeiros 
eram propícios. Além disso, a poesia épica foi sempre uma fonte vital de inspiração para Ésquilo, como para as suas palavras insólitas. $\bigcirc$ ambiente bélico, com a força do colorido do armamento, deu à pena poderosa do trágico matéria para alguns dos seus momentos mais vistosos. Os sons do combate, a desordem dos movimentos no campo de batalha, os metais fulgurantes que recobrem os guerreiros são traços constantes nos seus versos.

Com esta cadência vocabular muito própria, Ésquilo dava voz a histórias que, por sua vez, se afastavam da experiência imediata dos Atenienses do seu tempo. Descobrir, sob os enigmas da acção, confluências com a sua própria vivência custava aos espectadores de Ésquilo um esforço de leitura e de compreensão. Os seus temas ascendiam a um passado heróico e movimentavam gerações de homens e de mulheres de antanho, cobertos de uma superioridade e grandeza que a distância consagrava. Não havia originalidade nesta preferência, porque afinal as lendas de que se servia eram tradicionais e conhecidas de todos. $\mathrm{O}$ que importava porém, para o poeta e para o seu público, era sobretudo a forma, essa sim original em cada nova versão, como a história era recontada e os processos accionados para a converter em drama. Como muito a propósito afirma Taplin 2: 'É de facto na dramatização que a arte reside; não na história, mas em como ela se converte em drama'.Também nesta perspectiva a tradição impunha regras e convenções na maneira de organizar a aç̧ão, de representar em cena um conflito, de dar expressão a sentimentos através de atitudes e de gestos. Mas a cada poeta cabia, mesmo assim, uma margem de identidade própria e de criação original. A imagem de marca das produções de Ésquilo são os seus guerreiros orgulhosos, sobre imponentes montadas, de arreios ornados de campainhas, mergulhados num mundo de trombetas e de lanças, que respira a violência primária de uma guerra empreendida por heróis do passado que, à primeira vista, deixam no auditório a impressão de uma galeria envelhecida e ultrapassada. Mesmo quando se trata de mitos que sobretudo valorizam crimes de família e tensões domésticas, o poeta faz reviver determinadas figuras de heróis que, nos seus defeitos e virtudes, deixam transparecer um código de valores que regeu o mundo guerreiro do passado. Pela insistência nos temas bélicos, a majestade do teatro esquiliano ganha novos contornos.

2 Stagecraft, 27. 
Do Hades de Rãs, o próprio poeta aponta os Sete contra Tebas e os Persas como duas das suas criações mais características e que melhor representam um certo tipo de preferência (1019-1027).Tomadas do sopro de Ares, elas são dois exemplos da sua preocupação em interferir pedagogicamente sobre um público que deseja valente e superior na sua dedicação à pátria. Dioniso porém, o árbitro da contenda e o símbolo por excelência da qualidade crítica do espectador, traz ao comentário do poeta uma achega importante para a nossa perspectiva (Rãs 1028-1029). Dos Persas não foi a mensagem veiculada pelo texto que perdurou na sua memória; o que o deus reteve foi o efeito de cena e aquele inesquecível momento em que o seu teatro se encheu do ruído dos lamentos e do movimento lutuoso das mãos de um coro de velhos; a cena vibrava então de uma imagem de angústia que separava um passado de prosperidade de um futuro incerto. Com esta preferência, o deus do teatro valorizava, acima do sentido geral de uma produção, alguns traços felizes da representação, capazes de exprimir ou de dramatizar o sentimento subjacente a cada episódio. Deste exemplo padrão citado dos Persas avultam, antes de mais, as potencialidades de exploração de comportamentos rituais em cena. Decalcados sobre a vida real, os rituais criam em cena solenidade $e$ consciencializam sentidos ou emoções que lhes são intrínsecos. À ideia de um contexto ritual associam-se efeitos cénicos poderosos; as palavras e os gestos multiplicam-se como contributos eficazes à expressão de conjunto. A imobilidade contraposta ao movimento, ou o silêncio em contraste com a palavra são processos que transmitem um código de sinais muito expressivo e de há muito fixado. A cada um deles estão subjacentes convenções de estratégia e de efeito teatral. $\bigcirc$ respeito estrito por esses códigos ou a interferência ou a quebra da convenção, de acordo com o potencial criador do artista, são no teatro, em todos os tempos, condições de eficácia nunca esgotadas. Por fim, ao elemento ritual e à impressão profunda do movimento e do gesto, Dioniso, no seu apreço pelo coro de Persas, acrescenta ainda o factor de exótico que advém da qualidade de estrangeiro deste grupo. Deste conjunto de elementos só podemos subscrever a opinião do deus: a cena que a sua memória reteve era, em todas as suas componentes, profundamente esquiliana, para além de corresponder a um Ésquilo no seu melhor. Mas pela nossa memória, muito mais limitada do que a de Dioniso perante o espólio estreito que conservamos, perpassam outros quadros paradigmáticos da produção de Ésquilo que ostentam traços paralelos: o kommos ritual sobre o 
túmulo de Agamémnon, em Coéforas, com a participação de um coro de cativas troianas; ou a actuação das Erínias, em Euménides, exibindo a sua estranha natureza de deusas das trevas em pleno ritual de maldição. Em todos estes momentos o rito, o gesto e o exótico constituem a mola propulsora de enormes momentos de espectáculo. Mas uma observação se impõe acrescentar a este propósito; de 'espectáculo' não deve inferir-se a ideia de uma exploração meramente superficial ou exterior. Para além da vibração visual, cada uma destas cenas contém um sentido profundo, posto ao serviço da essência do drama respectivo, em nome de uma coesão dramática que Ésquilo nunca pôs em causa.

No desenvolvimento agonístico de Rãs, Ésquilo defende, por fim, uma teoria de coerência interna da obra dramática (eikós, v. 1060) muito apoiada pela crítica antiga ${ }^{3}$. Do ponto de vista técnico, o tom da linguagem que usou pretendeu ser conforme à categoria semidivina das personagens e à solenidade dos trajos. Curiosamente dos diversos efeitos materiais que poderia valorizar é ao trajo que cabe a preferência, sem dúvida porque detinha, no conjunto das imagens de cena, uma visibilidade maior. Está-lhe associada a caracterização das personagens, por estatuto social, idade ou mesmo proveniência. A par destes pressupostos, acrescem os factores de mudança no trajo ao longo da representação, das vestes faustosas para os farrapos por exemplo, que acompanham o evoluir da acção e de um destino. $O$ que quer dizer que o trajo vive da coerência com a personagem que o usa e com a cena em que se enquadra; a sua mudança será sempre um contributo adequado, dentro da mesma teoria da coesão dramática, à mudança profunda nos acontecimentos que sustentam a linha de acção. A coerência impõe-se então a todos os níveis, poético, dramático e cénico. Neste equilíbrio reside o segredo de uma grandiosidade e de um impacto eternamente válidos.

${ }^{3}$ Cf. a sua teorização posterior em Aristóteles, Poética 1456a 24 sq., a respeito da intriga dramática. 
(Página deixada propositadamente em branco) 
O Coro 
(Página deixada propositadamente em branco) 


\section{Coros de mulheres}

\section{Coro de Coéforas. O ritual fúnebre}

A caracterização do coro de Coéforas - fúnebre e suplicante - é verbalizada, desde logo no monólogo de abertura, por uma testemunha oculta em cena: Orestes, que acaba de regressar de um longo exilio. Estranho à situação actualmente vivida em Micenas, o filho de Agamémnon, tal como os espectadores, regista sinais e arrisca para eles uma interpretação hesitante ( 10 -21). Atrai-lhe o olhar, antes de mais, um cortejo feminino, grupo lento e solene no seu caminhar, envolto em longos véus negros de luto. A rigidez do movimento, como o tom sombrio das vestes, exprimem a presença da morte. Pela reflexão de Orestes, também o público se interroga sobre a especificidade do mal: luto recente ou ainda a homenagem devida à vítima de um crime, cuja mancha não redimida continua a pesar sobre os destinos do palácio? As libações que transportam, como a presença de Electra que com elas avança, resolvem as últimas dúvidas. A filha de Aigamémnon partilha com as mulheres do coro a lentidão do passo como os amargores do sofrimento. É o rei assassinado o destinatário desta homenagem fúnebre, que mobiliza os filhos juntamente com os elementos de uma comunidade que se lhe mantêm fiéis. Sob a convenção do cortejo fúnebre e hierático, Orestes percebe o sabor vago ainda, mas firme, de uma vingança que a profundidade do luto reclama. A aproximação do túmulo denuncia também uma atitude previsível, a da súplica, que deverá ganhar, da parte do morto, adesão e patrocínio para a acção humana que se prepara.

O párodo complementa, com a actuação do coro, a situação antes sugerida (23-83). À evidência de que tem um sentido fúnebre o ritual que a nossos olhos se prepara, acresce a ideia de uma ordem que projecta para fora de cena a iniciativa; sobre a mobilização dos presentes impera um encargo, 
que acrescenta ao sentimento de muitos a necessidade que o temor impôs a outros: Antes que este impulso ganhe forma - como ritual de purificação ou de profilaxia de um pesadelo que perturba Clitemnestra - oferece-se à nossa vista o impacto do ritual. Às oferendas junta-se a vibração dos movimentos. $\bigcirc$ público é chamado a observar a convicção de cada gesto: o bater insistente dos braços, os sulcos ainda vivos de sangue que lavram as faces das mulheres, os soluços e lágrimas audíveis e insistentes. No que é uma bela imagem do envolvimento pleno das coéforas, o linho das vestes parece gritar em uníssono com as suas portadoras, decerto por efeito sonoro da agitação do movimento, mas não menos porque mãos sofridas as transformaram numa imagem de dor, reduzidas a farrapos. Os trajos ganham assim um sentido complexo, na capacidade que possuem de exprimir, pela cor, material, forma e estilo, todo um conjunto de nuances, que vão da condição social a um certo estado de espírito que exige exteriorização vigorosa.

Se um sentimento une todas as forças que executam este ritual, esse é, sem dúvida, o medo: o daqueles que temem a vingança que se anuncia sobre o crime que cometeram, e o dos que, alinhados do lado da justiça, aguardam, também eles trémulos, a hora desejada em que um novo golpe virá saldar a dívida em aberto. Sob a evidência do gesto, o coro oculta a força dos sentimentos que, em palavras tímidas, exprime como uma confissão do invisível: as lágrimas que, no segredo dos véus, a alma verte e aquele luto que, debaixo do negrume exterior, congela o coração. Para estas mulheres as palavras e os gestos são ditados pelo ritual; mas sob a convenção, o desespero que eles exprimem é autêntico e tem uma implicação muito pessoal.

Informação e emoção, em progresso equilibrado do prólogo para o párodo, definem a actuação deste grupo de mulheres que é, por enquanto, a delineação vaga mas verdadeira de tudo o que constitui a essência da peça.

\section{Coros de suplicantes}

Os coros femininos de Sete contra Tebas e de Suplicantes partilham os traços de um certo padrão que tem a súplica como sua marca convencional. O sentimento principal que continua em causa é o medo, mas em consequência de um perigo palpável e iminente. A presença de uma ameaça próxima, de um lado, e a esperança de um refúgio ou auxilio seguro, do outro, justificam 
emoções e gestos de um grupo de mulheres que, num permanente crescendo, tende a atingir os níveis de uma quase histeria. São características comuns neste tipo de coro uma energia inabalável, o sentimento que lhes determina a resistência, mas acima de tudo uma confiança firme e intuitiva nos deuses.

O cenário exigido por este motivo pressupõe a existência visível de um $a^{a} t a r^{4}$ e de estátuas de deuses, diante dos quais as mulheres se prostram e para que dirigem gestos repetidos de apelo. $\bigcirc$ fr. 379 Radt, de uma tragédia não identificada de Ésquilo, descreve com precisão o movimento de um coro súplice, quando alguém recomenda: 'Perfilem-se em torno deste altar, numa formação circular, e façam as vossas preces'. Não menos interessante é a observação feita por $\bigcirc$. Taplin ${ }^{5}$ a propósito da coreografia convencional que corresponde à entrada do coro. A existência de uma prática mais ou menos constante permite ao poeta sugerir um contexto dramático particular, sempre que o párodo se processa de modo irregular ou desordenado. Esta sugestão é especialmente oportuna no que se refere a coros de suplicantes. No caso particular de Sete, o efeito da entrada agitada do coro beneficia ainda do contraste flagrante com a segurança disciplinada que constitui a mensagem transmitida pelo soberano no prólogo. Expresso em docmíacos, o párodo da peça tebana não deixa dúvidas sobre 0 tom altamente emotivo que nesse momento se instala em cena. A chegada das Danaides, que constitui a abertura de Suplicantes, é um ponto de partida para os movimentos determinantes de toda a peça: um primeiro que é de refúgio num lugar sagrado, seguido do que será o abandono desse lugar depois de conquistado o acolhimento pleno da cidade. Logo este quadro de súplica é crucial como ponto de partida, como é seguro que toda a coreografia, nos anapestos iniciais como no canto estrófico que se lhes segue, deve ser expressiva do voo das Danaides em fuga como da sua busca ansiosa de um refúgio.

Pelo contexto particularmente agitado em que se enquadram, estes episódios de súplica tendem a combinar, num estranho efeito de piedade e de insegurança, gestos que correspondem ao convencionalismo hierático da prece com atitudes que traduzem o excesso emotivo a que estão sujeitas as almas dos mais fracos ou mais sensitivos (Sete 78-180, Suplicantes 1-175).

${ }^{4}$ Sobre a existência e a localização em cena de um altar nas peças de suplicantes, cf. R. Rehm, 'The staging of suppliant plays', GRBS 29.3 (1988) 263-307.

5 The stagecraft of Aeschylus (Oxford reimpr. 1989) 141. 
A expressão eficaz do medo em cena mobiliza recursos de texto, de atitude e de movimento. Repetir palavras que exprimam a ideia de 'medo, tremor, pavor', com a agudeza de um grito (cf. Sete 78, 'este é o brado do meu medo'), produz uma certa tonalidade e um envolvimento adequado a um episódio que é particularmente sonoro na sua expressão. Diante dos altares dos deuses, o grito espavorido cede lugar à prece; mas a própria indecisão sobre que deuses invocar, ou a necessidade de mobilizar para uma causa todas as forças divinas, estimula a corrida veloz, de estátua para estátua, em busca de um socorro que parece difícil de precisar.Abatidas pelo pavor e pelo esforço, as mulheres caem, prostradas e rendidas, braços estendidos ou enlaçados em torno das imagens que representam a salvação. Os lábios entoam uma cadência iónica, enquanto as unhas ferem a face e as mãos rasgam as vestes, numa atitude que é já o lamento sobre uma morte apenas anunciada (Suplicantes | | |-||4): 'Tais são as negras dores que pronunciam os meus gritos agudos, os meus soluços profundos, as torrentes das minhas lágrimas - ai, ai! - e estes brados que soam a toadas fúnebres. Viva ainda, sou eu que entoo o meu próprio luto'.

O ritmo do pavor e da súplica corre de acordo com os sinais da proximidade do perigo. Um inimigo perfila-se num horizonte exterior ao que a cena permite ver, cuja presença ameaçadora se avalia pela percepção das mulheres, aumentada pela imaginação que redimensiona o perigo; com todos os sentidos despertos, são elas que lhe captam e transmitem a presença. A sua natureza e dimensão será em cada caso diversa. As mulheres de Tebas, nos Sete, apavoram-se diante da presença de um invasor fora das muralhas, que as ameaça na qualidade de cidadãs e de mulheres livres, membros de uma população atingida pelo perigo de um ataque guerreiro e de uma possível derrota e rendição. As filhas de Dânao sofrem as penas do exilio, afugentadas da terra natal por um perseguidor que atenta contra a sua condição feminina, procurando impor-lhes pela violência um himeneu que as horroriza. Assim, a fuga das Tebanas limita-se ao percurso da cintura de muralhas que protege a sua cidade e a salvação que imploram para si próprias corresponde à da própria cidade a que pertencem. Enquanto que as Danaides percorreram um longo caminho de fuga até Argos, seguidas de um perseguidor que tenta atingi-las e a todo aquele que as proteger; logo elas representam, para a cidade a que apelam, outra ordem de interesses que, se exige o cumprimento rigoroso da divina lei da hospitalidade, é portadora de um perigo terrível e sangrento. No meio de toda a agitação que progride do exterior para abalar a 
estabilidade profunda de uma polis, só os deuses se mantêm seguros e estáveis, como detentores de um ascendente que os coloca acima de todos os conflitos; por isso, por entre o movimento da cena, são eles a única visão imóvel na solideż das estátuas que os representam.

À teatralidade que a visão do medo proporciona, corresponde uma outra não menos efectiva, que é preciso fazer vibrar do espaço extracénico. Porque pela aproximação dos ausentes se mede e justifica a emotividade reinante.

A presença do perseguidor em Sete produz a imagem de uma cidade sob invasão. Fechadas no círculo das muralhas, as mulheres não vêem o avanço inimigo; mas a sua presença, registada pela proximidade crescente dos ruídos, torna-se mais e mais palpável e cria um pavor profundo exactamente porque uma avaliação correcta se torna impossível. Primeiro à distância, o marulhar sonoro de uma enorme vaga marinha anuncia o movimento de mobilização de um enorme exército. Logo uma nuvem de poeira - 'mensageiro sem voz', 82 - oferece à vista a confirmação do som. Vem depois o ruído dos cascos que voa e traz consigo a ameaça até às muralhas de Tebas. Já sobre elas, o clamor penetra, oferecendo aos olhos da imaginação a proximidade da mancha branca dos escudos que fervilha em torno da cidade, num choque que denuncia a excitação dos invasores. Estimulada pela pressão do perigo, a mente das mulheres capta todos os sinais, numa sinestesia expressiva:'vejo este ruído' ( 103$)$, quando já o golpe dos dardos fere a resistência das defesas de Tebas. $\mathrm{Na}$ boca dos cavalos os freios ressoam, o chiar dos eixos anuncia o avanço dos carros dobrados ao peso da multidão guerreira, as pedras desabam sobre as ameias, enquanto as portas rangem sob a pressão dos escudos. Cada ruído, no pormenor, é agora perceptível, porque o inimigo se pressente a uma distância que só a barreira de muros e de portas delimita. Ao espectador não é mesmo necessário proporcionar o eco dos ruídos, que bem pode medir pelos gritos convincentes das mulheres. Com W. G. Thalmann ${ }^{6}$ se pode concluir que 'o público toma parte na criação deste efeito dramático, no momento em que a sua imaginação elabora o material que Ésquilo the fornece'.

As Danaides, igualmente atentas, adivinham por antecipação o 'enxame' dos filhos de Egipto que se aproxima, também ele um perseguidor feroz na sua insolência (Suplicantes 30-34). Mas porque, juntamente com seu pai Dânao,

${ }^{6}$ Dramatic art of Aeschylus (New Haven and London 1978) 93. 
se encontram abandonadas num universo desconhecido, têm de registar os sinais de aproximação e de interpretá-los como de amigos ou de inimigos. Repetindo palavras de Sete (cf. Sete 82, Suplicantes 180) o velho Dânao, colocado num posto de observação $(189)^{7}$, anuncia, vinda da cidade, a nuvem de poeira que se ergue nos ares, para trazer a mensagem da presença de um exército, logo confirmada pelo som das siringes. Capaz de dominar pelo olhar o espaço exterior, Dânao descreve e avalia a imagem que se desenha no horizonte: um corpo armado de escudos e de dardos, que se desloca a cavalo e sobre carros (182-183). A emotividade que a informação produz é desta vez mais controlada, porque Dânao desde logo constata que se trata de gente do lugar, que não deseja mais do que inspeccionar a presença de estranhos sem uma necessária intenção violenta. Da parte das mulheres em perigo pressentese uma mobilização não isenta de emotividade, própria de quem, numa situação de alarme, antevê uma possibilidade de socorro. Mas é apenas necessário que a convenção de uma súplica se cumpra.

Só mais tarde, quando a protecção de Argos às suplicantes tinha sido assegurada, ocorre a chegada do perseguidor. Por força da generosidade argiva, as mulheres dispunham, tal como as Tebanas de Sete, da protecção da cidade a que se tinham acolhido; mas, por enquanto, a segurança não passa de uma promessa sem que haja ainda entre elas e o inimigo a barreira física das muralhas da cidade. Nestas circunstâncias a iminência do perigo não as deixa menos susceptíveis. A estratégia dramática é, porém, outra. Colocado num ponto de observação, Dânao vê e descreve em pormenor, vinda do lado do mar, a presença do inimigo (7|3-733); ainda à distância, todos os pormenores do barco que se aproxima e do desembarque que se segue são perceptíveis. O controle visual da situação recomenda calma e prudência, porque permite a tentativa de uma estratégia de defesa adequada. Logo é outro o ponto de partida por que se irá desenvolver a reacção feminina.

Para além da presença tranquilizadora dos deuses como promessa de neutralização de uma ameaça temida e próxima, estas cenas de súplica comportam ainda um contraponto masculino de natureza diversa que, embora não constitua um perigo para as mulheres, mantém para com elas

7 Dânao menciona por duas vezes (Suplicantes 189,713) o seu ponto de observação, uma plataforma elevada, visível em cena ou apenas sugerida, que de toda a maneira assegura que os movimentos fora de cena sejam visualmente controlados por quem representa os interesses das suplicantes. 
uma relação dúbia, de solidariedade ou de contestação. Participando dos riscos que afligem o grupo feminino, este elemento masculino reage, face ao perigo, de uma forma mais regrada e racional. É por isso um contributo dramático importante na leitura da situação e, pela sua reacção, coloca-se de alguma maneira ao controle dos acontecimentos. Mas sobretudo impõe ao pavor feminino um modelo de atitude oposto, que coloca o pólo da dissidência ou a actuação adequada numa outra perspectiva.

Embora reconheça às mulheres competência e legitimidade para se solidarizarem no perigo e para se empenharem na sua neutralização ${ }^{8}$, a autoridade masculina diverge, de forma mais ou menos peremptória, do comportamento exaltado que é próprio da natureza feminina. Várias são as justificações apontadas para a reacção violenta de Etéocles perante a exuberância das Tebanas; para além de alguma animosidade espontânea para com as mulheres, que advém dos próprios condicionalismos da sua origem, factores de personalidade como a natureza militar do comandante das tropas de Tebas e a noção exacta da conveniência dos comportamentos e das palavras em hora de crise podem explicar-lhe a agressividade. Mas do mesmo Etéocles colhemos o paradigma do que deve ser o comportamento correcto de um suplicante, por isso mesmo promissor de um resultado positivo para a salvação por que se anseia (|82-186).

Expressa a divergência de posições, um diálogo epirremático faz vibrar na cena a contradição que os sexos, dentro da sociedade humana, representam. Nele se alternam censuras racionais com medos exaltados; a cada conselho de moderação, o coro responde com manifestações descontroladas de susto, súplicas exaltadas aos deuses, desorientação de palavras e de gestos. Na opinião do comandante, qualquer sinal de histeria ou de pânico, que multiplica o medo e contagia os espíritos, mesmo os mais sensatos, deve ser evitado em nome da moderação e de um sentido positivo para as palavras proferidas em tempo de crise. Que das preces se exclua a ideia de socorro, que implica perigo, para se valorizar a de aliança divina, que promete salvação. Que se não abracem os deuses, quando as palavras que se pronunciam exprimem o terror da derrota. Que aos gritos e aos gemidos selvagens se sobreponha o tom festivo de um

8 Parece consentâneo que, na versão esquiliana os sacrifícios públicos a realizar em tempo de guerra sejam competência feminina; Atossa e Clitemnestra assumem esse encargo, uma perante a derrota, outra diante da vitória. 
péan, que dá àos mortais confiança e aos deuses reserva a promessa de lealdade de uma cidade que sobrevive à angústia do perigo. Mau grado uma certa irritabilidade própria de um general que não vê as suas ordens acatadas, e por isso ele próprio fraqueja no que devia ser um comportamento estritamente racional, Etéocles não perde, pelo menos em teoria, a noção do que deve ser o tom formal e isento de emoções de uma prece aceitável e construtiva. Ao mesmo tempo, Ésquilo denuncia o que existe de incompatível entre duas mentalidades face a algo tão sensível como o culto dos deuses. Orientado por argumentos racionais, o rei é incapaz de compreender a emoção feminina e de lhe dar uma resposta eficaz; enquanto o coro, embora seja compreensível a sua reacção exaltada, não tem como refutar o ponto de vista prático do general. Por isso só o silêncio, rendido mas não vencido, sela a disputa que os separa. Cada um deles exprime uma reacção cívica diante de um invasor feroz que investe contra Tebas: a determinação competente e responsável de um chefe, diante de um grupo que encarna as instituições sociais e religiosas da polis, dotadas de uma profunda capacidade de temer e de sofrer.

Se Etéocles ganha por algum tempo o silêncio das mulheres, não thes conquista a submissão nem as faz abdicar das suas súplicas aos deuses. Mas, no primeiro estásimo (287-369), o tom muda, sobretudo porque o medo feminino ganha uma conotação reflexiva e intimista: Talvez mesmo o espaço em que o coro se passa a movimentar mude também, da cena, onde tivera lugar o conflito com Etéocles, para a orquestra, onde permanece até ao fim da peça. As preces têm agora um tom mais moderado e a comunicação que as Tebanas dão do seu estado de alma uma outra expressão; como escreve K. Valakas9', 'personagens agitadas, cujas palavras e gestos parecem fora de controle, aparecem no párodo, enquanto aqui surge um grupo que pensa por imagens'. A abertura deste estásimo é ainda o eco do canto anterior: regressam os medos que a presença audível do inimigo não tranquiliza. Dos deuses, as mulheres imploram agora, de acordo com as recomendações de Etéocles (217-222), que se ponham do lado dos defensores e não permitam que se arruine a cidade que sempre lhes foi fiel. De Tebas, o pensamento ergue-se-lhes para um plano mais alargado, onde ganha espaço a imagem

9 'The first stasimon and the chorus in Aeschylus' Septem against Thebes', SIFC 86. I-2 (1993) 61. 
universal do que é qualquer cidade sitiada, infelizmente para a Grécia de Ésquilo uma experiência recente. $\bigcirc$ tom é marcadamente épico, próprio de uma lliou persis, que se tornou convencional na literatura grega a partir do séc. $\mathrm{VI}$ a. C. (cf., e. g., Ésquilo, Agamémnon; Eurípides, Troianas). Em imaginação, as mulheres visualizam o que é, nos seus traços constantes e previsíveis, a ocupação de uma cidade: os incêndios, que destroem o que constituía a protecção da comunidade, a violência sobre as mulheres, arrastadas e violadas, depois que os heróis, defensores da cidade, perderam a vida. Mais uma vez o quadro da destruição junta às imagens o poder dos sons; o quadro enche-se dos gritos, confusos como as próprias ruínas dos edifícios, sangrentos de violência e de morte; ouvem-se os soluços surdos, que sondam as sombras do futuro que será de escravidão. Com a ressonância de um eco, os ruídos que agora penetram o âmago da cidade destruída repercutem os que anunciaram a chegada e a investida do invasor. No seu todo, a imagem que as mulheres criam da guerra é, no dizer de Gagarin ${ }^{10}$, 'especificamente feminina, onde se destaca 0 sofrimento e a destruição sobretudo no que eles representam de perigo para as mulheres, enquanto a glória da vitória ou a derrota heróica são rejeitadas'. Mas repartido entre o medo e a esperança de salvação, o canto das mulheres tem um sabor apotropaico: que a derrota não passe de uma miragem, e prevaleçam a superior vontade dos deuses aliada às forças humanas dispostas para as grandes causas.

Dânao desempenha, junto das filhas, o papel da autoridade masculina que aconselha e organiza o comportamento de um grupo feminino em fuga diante de um perigo (Suplicantes 1-40). Mas desde logo, ao contrário do que acontecia com Etéocles, a sua intervenção é aceite e consensual com os desejos e comportamentos das mulheres. Foi sob proposta sua que as Egípcias optaram pelo exilio, que escolheram Argos como o refúgio ideal pela relação de sangue que as une à cidade, e adoptaram a atitude conveniente de um bando de suplicantes, exibindo nos braços os ramos de oliveira, enlaçados em brancas fitas de lã. Dânao tem a noção exacta das conveniências que a situação do grupo que conduz exige. Apelar a um parentesco é garantir-lhe um lugar e uma justificação dentro da sociedade a que se dirigem. Tomar, por outro lado, a atitude que corresponde a um código de convivência social é sugerir à comunidade de que se aproximam o papel que se espera seja o seu. Com

10 Aeschylean Drama, 158. 
estes comportamentos, contidos nas regras da xenía, possibilita-se uma coexistência ou mesmo uma colaboração entre pessoas que não pertencem ao mesmo grupo. Só se pode, por isso, esperar dele sucesso que representa um código de respeito em relação às leis dos deuses e de cooperação entre os homens. $O$ tema aqui presente do acolhimento devido a suplicantes em fuga por parte de um governante que preza a justiça, ainda que a presença de refugiados traga inconvenientes ou riscos ao seu território, é também usado por Ésquilo em Euménides, por Sófocles em Édipo em Colono, e por Eurípides em Heraclidas e Suplicantes. Trata-se portanto de um padrão convencional, que se desenvolve através de estratégias dramáticas igualmente repetidas. Ao dar ao seu coro de suplicantes entrada em cena no próprio momento da abertura da peça, Ésquilo retrata a chegada de um grupo em fuga a um lugar sacro, o que já faz parte da convenção da súplica. $\bigcirc$ estado de espírito deste grupo de fugitivas é, de início, relativamente racionalizado, apesar de sofrer a muito curto prazo um incremento de exaltação. Hesitante ainda sobre a garantia do auxllio divino, o coro entrevê como alternativa a morte voluntária (|55-|6|), que o liberte do perigo que mais abomina, a submissão aos desejos masculinos dos seus pretendentes.

A aproximação de desconhecidos, de intenções ainda dúbias (socorro? Perigo?), aconselha moderação e rigor. Mais uma vez Dânao dita as regras que, tal como Etéocles, conhece bem e em cujo cumprimento se escuda; a convenção da súplica é então recapitulada em todos os seus pormenores (188-199): 'Mais vale, apesar de tudo, minhas filhas, sentarem-se sobre esta colina dos deuses, em assembleia. (...) Vamos, rápido, com os vossos ramos coroados de branco, atributos de Zeus protector dos suplicantes, piedosamente seguros nas mãos, respondam aos estrangeiros em termos súplices, entre gemidos e lágrimas, como convém a recém-chegados, dizendo sem demora que o vosso exilio não está manchado de sangue. Que nem um leve sinal de sobranceria se perceba na vossa voz. Que nenhum desafio, na modéstia dos vossos rostos, se possa ler nos vossos olhos'. Além de denunciadora de fragilidade, a atitude de um suplicante deve ser de modéstia e de abandono, nunca de exigência ou imposição. De facto, nas palavras de Gould "', os suplicantes devem assumir, para com aqueles de quem a sua sorte depende, uma atitude de auto-humilhação.

II 'Hiketeia', JHS 93 ( 1973$) 95$. 
Com os seus conselhos, Dânao deposita em mãos femininas a condução eficaz da súplica, e remete para estratégias líricas o processo dramático de avaliar o dilema de Pelasgo. Piedoso, o rei local não deixa de ser sensível aos deveres que dike impõe para com os suplicantes, que de resto assumem o comportamento que deles se espera. Mas, cumpridos os passos que pareciam conduzir ao acolhimento incontroverso das mulheres ameaçadas - a identificação de cada parte que é, ao mesmo tempo, a verificação de um ascendente comum -, eis que a aporia do rei Pelasgo se torna patente: obedecer às exigências da súplica, que a justiça divina protege, equivale a atrair sobre 0 povo que comanda os horrores de uma guerra violenta. A longa ponderação do problema adia, para depois da avaliação dos argumentos expressa em vários modelos de natureza lírica e epirremática, a inevitável exaltação do coro. Para além das benesses divinas, é sobretudo sobre a justiça dos comportamentos humanos que a atenção recai. A certeza do acolhimento unanimemente garantido por Argos apenas reforça, por um momento breve de alívio, o estalar da crise. Um canto de acção de graças a premiar tanta generosidade e já Dânao, do seu ponto de observação, anuncia a chegada dos perseguidores (7|0-7|4). Dois momentos simétricos suportam o desenvolvimento da acção: primeiro a vinda de Pelasgo, como uma promessa de socorro que tem de ser confirmada; para logo, assegurado esse apoio, ele ser posto à prova com uma nova chegada, desta vez do perseguidor egípcio. Por seu lado, o coro actua em conformidade; à prudência e calma com que reage diante da autoridade argiva, substitui agora, perante a violência próxima, uma reacção estimulada por temores irrefreáveis (734 sqq.). O contraponto convencional à exaltação feminina provém, neste episódio, não da repulsa ou animosidade masculina, como em Sete, mas por maior ironia da garantia de acolhimento há pouco, mas com tanta certeza, afirmada. As mulheres insistem nos perigos, a agressividade e o número dos inimigos; Dânao na decisão generosa e na capacidade de resistência dos seus aliados. À urgência do perigo, o velho pai responde com as delongas do desembarque. $O$ temor não cessa de crescer até um clímax, a que dá azo a visão tão temida do perseguidor. $O$ que as mulheres de Tebas não experimentaram a visão e a presença do inimigo - cria nas Danaides um extremo de emoção. Justifica-se assim o longo preparativo, retomado em pontos diversos da peça, da chegada do perseguidor, que oscila entre a esperança de que o perigo se afaste, seguida de uma intensificação progressiva do pavor das mulheres, que conduz à presença retardada daqueles que representam para as filhas de Dânao a razão 
palpável dos seus temores. Tudo que fora ordem e disciplina na súplica a Pelasgo dá lugar à fuga desorganizada. Sob o efeito da violência, arrancadas dos altares e forçadas a tomarem o caminho do navio, puxadas pelos cabelos, as suplicantes experimentam a amargura da rendição. Até ao momento em que a força da justiça regressa pela mão poderosa do rei pelasgo. A partir de então, os movimentos agitados do coro dão lugar a uma procissão organizada, de ritmo hierático, que conduz as suplicantes agora tranquilizadas do altar em que se abrigavam para um refúgio seguro, a cidade de Argos.

\section{Coros de Velhos}

Os coros de velhos parecem obedecer a um modelo de comportamento mais ou menos convencional. Se os considerarmos naquilo que é a competência tradicional de um coro do ponto de vista cénico - o canto e a dança -, percebemos que lhes convém, no que respeita a movimento, uma grande sobriedade. A idade física, como a condição própria da velhice, assim o impõem. Os Argivos que constituem o coro do Agamémnon exprimem, sobre a própria caracterização, palavras particularmente falantes (72-82): 'A carne velha' do seu corpo arreda-os de uma participação plena na sociedade a que pertencem, como se o pagamento de um determinado imposto, que é cobrado aos cidadãos, lhes tivesse sido já perdoado. Se comparados com a agilidade activa da juventude guerreira - a expressão madura do civismo - nada são. Da vida cumpriram quase o curriculum completo, dando agora na insegurança dos passos que precisam de um apoio a imagem da mesma fragilidade da infância. A bengala passou a ser a sua insígnia e a evidência da sua condição. Por isso a atitude coreográfica que assumem terá de ser condicionada por todas estas limitações: de mobilidade restrita, de gestos discretos, de passos lentos, como convém a quem 'erra como uma espécie de sonho visível em plena luz do dia' (8I-82). Por trás dos condicionalismos patentes na aparência física, escondem no entanto um espírito vivo, que não desmerece do dos jovens, a seiva que Ihes anima a alma é estimulante; apenas Ares não ajuda, naquele espaço onde a acção e a força, como complemento exterior da determinação íntima, são necessárias (75-77). Outros são os deuses que os patrocinam, a Persuasão, uma capacidade que radica nas fibras mais profundas e que tem por duração a própria vida (106-108). 
Os dois coros correspondentes a este padrão nas tragédias conservadas de Ésquilo são os de Persas e do Agamémnon, peças que giram em volta de campanhas militares no exterior (vide Imagem do poder). Nelas é prioritária a ideia de ausência daqueles que constituem as forças vivas da cidade - o rei e o exército sob seu comando. Nesse contexto, os velhos personificam, ao lado das mulheres, uma parte da sociedade excluída do combate. Tornam-se, por isso, representantes da componente cívica da sociedade, daquela que não pega em armas, sem deixar de ser uma vítima directa da guerra. A inactividade que Ihe é inerente num quadro activo de guerra estimula-lhe a expectativa sobre o resultado do conflito. Com a rainha a corporizar a condição feminina e os interesses familiares da comunidade, os velhos tendem a manter um diálogo dada a proximidade das suas situações. Mas ganham ainda, em consequência da mesma inibição de movimentos, uma competência própria: a de esperar, o mesmo é dizer, de gerir a angústia da espera, de lembrar o passado e de especular sobre o futuro, de ajuizar a respeito de todos os sinais contraditórios que se cruzam sobre os acontecimentos, e finalmente a de saber partilhar, com lealdade digna e sensata, os resultados. Toda esta intervenção está concentrada sobre aquela que é a sua enorme força: a da clarividência e da prudência.

Toda esta actuação sobretudo mental ganha maior significado em função de um estatuto social que lhes pode ser atribuído: o de conselheiros ou de homens de confiança do monarca. Com ele, o seu papel não se limita ao de simples observadores, mas permite-lhes uma intervenção de natureza política, que justifica uma capacidade de avaliação consagrada pelo reconhecimento da sua competência. Esta outra faceta torna-os, de legítimo direito, interlocutores da autoridade masculina do soberano, censores competentes das decisões régias e uma espécie de contraponto à actuação do monarca. Fraqueza física e força mental dão ao coro de velhos a voz da sensibilidade e da prudência, uma espécie de expressão global dos anseios de uma sociedade em todas as forças que a constituem: a da responsabilidade governativa, de que depende o equilíbrio colectivo, e a da gestão de sentimentos e afeições, que garante a felicidade e a segurança ao núcleo pessoal de cada criatura humana.

A importância, dramática e política, dos velhos conselheiros de Susa é evidente desde as primeiras palavras dos Persas. Ésquilo optou, nesta tragédia, por dar ao coro primazia absoluta, anulando o prólogo em favor da sua entrada imediata. A sua situação e condição é desde logo enunciada (I-7): os velhos são, na ausência dos combatentes na Grécia, os guardiães do palácio e 
de tudo aquilo que ele significa para a identidade, poder e riqueza do império persa. Na falta do soberano, eles são os procuradores da sua autoridade, os Fiéis, especificamente incumbidos pelo rei da salvaguarda de toda a comunidade. Estatuto político, além da condição aristocrática e da experiência de vida, dão a este coro uma auréola de superioridade. Para além da sua posição privilegiada na corte, os velhos de Susa reagem com uma profunda sensibilidade, estimulada pelos acontecimentos e por uma tremenda apreensão que o silêncio que caiu sobre os factos desperta. É sobretudo o tempo longo e a falta de notícias ou de quaisquer sinais do que possa estar a acontecer no terreno da campanha que provoca uma terrível angústia (8-|5). Os anos passaram sobre o dia da partida de tudo o que constitui o poderio persa ( | - | 2): 'a força nascida na Ásia partiu, completa'. Um extenso catálogo ( 6-58) cumpre, neste momento, uma função relevante: a de retratar o poderio ausente, aquele potencial enorme, pujante e invencível que cercava o rei na execução do seu projecto. Com esta memória, expressa em tom narrativo e tranquilo, os velhos recuperam por um instante alguma serenidade; - quadro é afinal restaurador de uma confiança que assenta na força incomparável do oriente. Assim começa a fluir o grande movimento de fundo desta tragédia, a oscilação entre esperança e temor, que inicia um processo constante de adensar de sombras e de aprofundar de certezas, a partir de um quadro de poder até à ruína total. De todo este percurso, o coro é testemunha e participante activo, como representante de um povo debaixo de múltiplas reacções. A mudança de tom do narrativo para o lírico (65- I39) corresponde a uma outra expressão do coro. Da memória objectiva de um quadro que retêm, os velhos passam para a avaliação especulativa do sentido oculto de cada decisão do invasor. Com este fluir estético, proporcionam o alargamento do cenário e da acção para além dos seus limites imediatos. Por sua intervenção o público é chamado a fazer um percurso temporal, como também uma reflexão sobre o sentido dos factos, das aparências para os conceitos que thes estão subjacentes. $O$ coro possui portanto uma visão que o coloca numa perspectiva privilegiada, de observador e de intérprete de tudo o que justifica um simples momento actual de experiência. No caso dos Persas, o coro coloca, por trás da acção, os grandes princípios que regulam o episódio central na peça: a invasão da Grécia pelo oriente. $O$ tom da linguagem muda, do descritivo para o valorativo: o exército sob o comando régio é conduzido por uma intenção, a de destruir, para além da de possuir ou conquistar; em 
nome dessa ambição, está disposto a todos os excessos, mesmo aqueles que atingem a autoridade divina, como o domínio do mar, o jugo lançado ao pescoço de Posídon. Apoiado pelos trunfos do poder, o número e a força, o monarca mergulhou numa aventura grandiosa, conduzido por ate, a irreflexão precipitada que arrasta consigo a punição divina. Cumpria, com mais esta campanha, o destino persa dentro de um lema tradicional: preserva o que herdaste e aumenta-o sempre. Não sem que a própria dimensão do projecto, voltado para as lonjuras insondáveis do desconhecido, não traga ao comportamento habitual da corte persa uma margem de risco inédita. Com esta reflexão, o coro redimensionou o acontecimento histórico numa perspectiva mais alargada, onde a condição humana se confronta com as regras superiores de um universo regido pelos deuses e pelo destino. Com este aprofundamento, os Persas trouxeram de volta à cena a angústia, quando se torna transparente, sob as suas interrogações, que a grandeza, se é até certo ponto amiga da segurança, é também, se excessiva, motivo de perigo e de punição. $\bigcirc$ tom é mesmo mais agudo, embora nada tenha entretanto mudado a não ser a consciência mais lúcida da situação (| |5-139). Por entre exclamações e perguntas emocionadas, o coro ecoa também o sofrimento de um povo, ampliando assim a repercussão de uma aventura arriscada; a sua aflição já não é apenas causada por uma expectativa que o silêncio produz, agravada pela reavaliação de um processo de guerra; ela é a expressão de um temor generalizado que aflige, de modo íntimo, cada grupo social: os combatentes, pela sua vida; os cortesãos, pelo vazio indefeso de um palácio privado de segurança; as mulheres, pelo horror da viuvez. Num párodo elaborado, o coro de Persas cumpriu uma vasta missão dramática, com tons múltiplos, em consonância com cada um dos fios sensíveis da acção.

Estabelecida a sua natureza e função, o coro actua como personagem perante as restantes personagens, em absoluta coerência com o plano traçado pelo párodo. O seu primeiro confronto é com Atossa, encarnação do poder e da sensibilidade das mães persas, símbolo dos anseios públicos e privados que se vivem no momento. Perante a rainha, o coro exibe a faceta política da sua personalidade (150-245). Prostra-se em profunda reverência diante do poder, saúda com veneração a viúva de Dario e mãe de Xerxes, a companheira de um poder que toca a condição divina. Prontifica-se a ouvir e a partilhar das apreensões régias, que são também as suas, agora fundamentadas por sinais do além, sonhos e profecias. Apressa-se, por fim, a cumprir a função de confidente 
e conselheiro, que o título de 'Fiel' Ihe exige. Com este diálogo o ambiente de tensão consolida-se. Para além de escutar com amizade, o coro sugere a actuação adequada e informa com precisão. Dentro dos limites de intervenção colocados à população que permanece na Pérsia, na ausência do monarca e suas hostes e na expectativa dolorosa de resultados, a sugestão dada aposta na súplica e na oração aos deuses e aos mortos protectores de um povo em sobressalto. Da sua parte, o coro avança agora, depois de no párodo considerar as cláusulas divinas, com outra avaliação condicionante do resultado: a identidade do inimigo terreno. Às perguntas curiosas da rainha, responde com uma precisão administrativa, sobre o número de forças, os chefes, o potencial financeiro e militar, os ideais de um adversário diferente, mas que deu já provas de uma capacidade bélica respeitável. Com esta informação objectiva, transmitida por uma esticomitia, os velhos completam o contorno de uma aventura, perigosa em todas as frentes, de que apenas falta conhecer o desfecho. Por este progresso no sentido de tornar perceptível o perigo sob a aparente estabilidade do poder, a queda da Pérsia está prevista em cena mesmo antes da chegada de notícias efectivas do exterior.

É imediata a vinda de um mensageiro que volta o movimento da cena num sentido novo, mas cautelosamente preparado: o de converter suspeitas e temores em certezas e luto. Esse volte face acontece com uma precipitação drástica, porque a mensagem abre com a menção definitiva de um resultado (255): 'O exército bárbaro foi completamente destroçado'. Com a mesma urgência, a atitude do coro muda para um modelo epirremático, em que nas falas breves e descritivas do emissário se intercalam os lamentos líricos do coro. A afirmação repetida da desgraça, produzida pelo mensageiro, suscita com a mesma cadência os soluços insistentes dos persas (256-289). Os tópicos anteriormente valorizados são repetidos: a perda total de um exército incontável, a fragilidade dos velhos que apesar de tudo sobreviveram a um golpe doloroso e mortífero, a ousadia excessiva da campanha, a potência inesperada do inimigo; apenas para enquadrarem, por entre gemidos de dor, a descrição minuciosa das baixas e dos momentos decisivos da guerra.

A este canto que introduz a narrativa da campanha, todo centrado no catálogo das forças vitimadas, corresponde, no final da fala do mensageiro (533547), um outro lamento centrado sobre os sofrimentos que recaem sobre toda a população. A prosperidade e a segurança perdidas, como o luto que atinge as familias, são agora confirmados. Avaliados os custos da aventura sobre 
os que partiram e os que ficaram, a atenção do coro recai sobre o rei, o responsável máximo por tão doloroso resultado. Tem lugar o treno por todos os que tombaram, entremeado de censuras abertas ao soberano que os condenou a uma aventura suicida (548-597). A lealdade não silencia a reprovação, o rei é acusado de leviandade e de loucura. De resto, a atitude dos conselheiros face ao poder régio abre, neste momento, uma perspectiva inovadora e essencial ao desenrolar futuro da peça. Pela primeira vez o coro compara Xerxes a Dario, seu pai e antecessor, um padrão de sensatez e de prudência política e, por isso, um espelho denunciador dos exageros imponderados de Xerxes. E teme, em queixumes profundos, que o poder real, francamente abalado, não resista e que com a derrota de uma só campanha seja todo o poder asiático que desaba. É a resposta a esta legítima preocupação que $\circ$ final da peça se encarregará de satisfazer. A grandeza persa, mesmo se atingida por um golpe duro, encontrará meio de sobreviver após o pranto pelo revés sofrido.Trata-se de uma espécie de defesa que os Persas adoptam contra as consequências futuras do desastre; reconhecê-lo, criticá-lo, pranteá-lo, para o exorcizarem e ultrapassarem ${ }^{12}$. Inabaláveis na sua fidelidade, os velhos mantêm-se solidários com a autoridade persa na superação da crise.

Juntamente com Atossa partilham de um ritual de evocação do fantasma de Dario (623-680). Este é um momento de grande emoção manifestada em brados e gestos que inicia a emotividade constante neste final: o lamento pelo desastre agora certo. Diante do fantasma de Dario, o coro dobra-se em veneração e respeito, para deixar a Atossa a condução de um diálogo que envolve o destino da Pérsia e do seu rei.

É longo o lamento que remata os Persas, um extenso canto de sofrimento, de angústia e de luto repartido, sob forma de kommos, entre Xerxes e o coro (908-1077). O filho de Dario é sobretudo saudado como o chefe de um grande exército que regressa sem os seus homens. Não há, nesse canto, a vénia devida a um grande rei, que marcara a atitude dos velhos diante de Atossa ou do fantasma de Dario. $O$ tom do kommos é de um progressivo crescendo, para o que se aliam palavras, brados e gestos. Xerxes multiplica clamores de infelicidade ('desafortunado', 'infeliz', 'miserável'), enquanto o coro insiste em memórias de grandeza, de número, de brilho, que são o lema de um poder perdido (908-930). Além de um canto de derrota, este é também

12 Vide M. Gagarin, Aeschylean drama, 40. 
um canto de luto, que se exprime com a exuberância asiática própria da corte de Susa (935-938): em gritos agudos e gestos descoordenados, molhados de pranto. Uma invocação de cada morto, seguida do respectivo lamento fúnebre, é ainda um derradeiro catálogo das perdas inumeráveis de uma guerra suicida. Para terminar num longo pranto de dor, em que os lamentos do monarca, logo repetidos pela voz colectiva dos conselheiros, irmanam todo um povo numa dor única que não exclui nenhum dos meios de se exprimir ( 1039 1077): choros, gritos, gemidos, golpes, lágrimas, soluços, arrancar dos cabelos, brados agudos, rasgar de vestes. À frente do que resta do seu povo, um Xerxes sujeito à maior humilhação comanda ainda, não uma juventude de guerreiros valentes, mas um grupo de velhos desesperados, a caminho de um palácio cujo fulgor aparente mal esconde uma dor exuberante e incurável.

São em muitos aspectos evidentes as semelhanças entre este e $\circ$ grupo de velhos argivos do Agamémnon, que no entanto não parecem ser mais do que um conjunto de cidadãos. A mesma dignidade, competência e lealdade anima os dois coros, destinados a viverem um progresso de angústia paralelo. Como representantes da sensibilidade colectiva, estabelecem um contraste permanente com os projectos do rei, bem como com a actuação de Clitemnestra. Há, no entanto, algumas diferenças que é necessário destacar. E a primeira de todas reside no facto de o longo e circunstanciado párodo do Agamémnon vir precedido da notícia, dada com euforia pelo Vigia do palácio, do sucesso da campanha e do regresso próximo do vencedor. Pareceria à primeira vista que este prólogo breve, iluminado pelo facho do êxito, devia instalar em Argos um ambiente de tranquilidade e de segurança. Mas aqui reside exactamente a linha de força da peça: é que esta alegria não parece convincente, há algo de indefinido que a não autoriza, um aperto vago nos corações que é preciso justificar e perceber. Para se tornar claro que todo o esforço feito no sentido de calar temores talvez injustificados apenas produz o resultado contrário, o de ir consolidando as sombras.

Boa parte deste sentimento de dúvida que percorre toda a peça advém das intervenções do coro. Para tal, o párodo dá um contributo decisivo. A contrariar a alegria do sucesso que parece rematar a aventura, o seu início foi marcado por um presságio sombrio. Nesta avaliação o coro de Agamémnon vai mais longe do que o dos velhos persas. Aí os conselheiros contentavamse com a reconstituição da imagem de grandeza que acompanhou a partida dos guerreiros e com vagos receios pelo seu resultado. Agora o coro é muito 
mais profundo na sua reflexão. Preocupa-o sobretudo o resultado que a vitória ganha desta maneira terá no futuro da Grécia, a partir da própria razão de ser da expedição. É a justiça da empresa e as suas consequências futuras que estabelece o tom que se prolonga por toda a trilogia.

Quer os anapestos da entrada como o canto lírico que se lhes segue têm por motivo comum os sacrifícios; em Argos, os de acção de graças, que motivam a vinda dos velhos movidos pela curiosidade de thes conhecer a causa; em contraste com aquele outro doloroso sacrifício, o de Áulide, que acompanhou o início da campanha. Embora prometendo a destruição de Tróia pelos Atridas sob a forma de um ataque bem sucedido de duas águias contra uma lebre prenhe, os deuses mostraram também o seu desagrado pelo excesso genocida deste quadro de destruição (vide A imagem do poder). Juntamente com a boa nova, Calcas lançou um brado de prudência contra o zelo divino pelas eventuais consequências de um acto que tendia a ser excessivo. Ártemis, a fundamentar as mesmas dúvidas, fez uma exigência elevada: o preço a pagar pela destruição das crias seria, em igual moeda, uma jovem cria, a filha do próprio comandante da expedição. Ao barbarismo que estas imagens de razia gratuita anteviam, o coro acrescentou a previsão de uma consequência inevitável: a de que uma outra vingança ditada pela cólera viesse instalar, no âmago da familia, nova violência. É muito profundo este longo canto, em que a lembrança de factos objectivos, aqueles que há dez anos acompanharam a decisão da campanha, se mistura com previsões e interpretações incertas, que apontam para um futuro duvidoso. Toda esta mescla de sinais contraditórios avulta de um refrão, com que o coro insiste numa espécie de moralidade $(121,139,159)$ que reparte cada fracção do seu raciocínio e define um primeiro bloco do seu canto: 'Diz o canto lúgubre, lúgubre, mas que prevaleça um bom desfecho!'

Ao tom incerto desta memória inicial, segue-se o 'hino a Zeus' (160-190), um momento de prece e de reflexão que os velhos dirigem ao deus supremo. Este exprime-se num novo tom, mais tranquilo e mais firme, que busca alguma descompressão na soberania resplandecente de Zeus. Íntima no seu apelo de abertura - 'Zeus!' -, a oração convoca o deus na sua plenitude, não por esta ou aquela prerrogativa concreta. A confiança substitui-se à angústia, perante a promessa de que só o supremo deus garante o esclarecimento e a luz espiritual que nenhuma sombra pode obscurecer. Nesse esplendor reside o inatingível da condição divina, o sumo conhecimento de que o ser humano é 
chamado a partilhar dentro dos seus limites. $O$ saber dos mortais obedece a uma lei, que o define e condiciona, 'aprender pelo sofrimento' (I76- | 78, 250$25 \mathrm{I}$ ); mau grado a cegueira e a incapacidade natural do homem para atingir a verdade absoluta, ela é algo a cuja aprendizagem os deuses o condenaram, apesar da sua resistência: a de progredir, a duras penas, para o seu aperfeiçoamento e redenção. Está consagrada a moral geral da peça, que o é também da trilogia, a busca de uma verdade superior que deve guiar os projectos e actos humanos; como bem observa A. Lebeck 13, ' o próprio drama da trilogia é marcado por uma preocupação com a causalidade. Procura afastar a obscuridade que cerca os acontecimentos, dando a ideia de uma série de momentos inconsequentes, em vez de uma linha coesa e por isso previsível'. $\mathrm{Na}$ sua dupla qualidade de observador e de interveniente, o coro circula com facilidade entre o plano particular e o universal, que articula a aç̧ão no seu todo. Assim regressa de novo a Agamémnon, condutor da aventura de Tróia, rodeado de obscuridades e incertezas, que está sob a mira dos deuses, pronto a iniciar o seu caminho de redenção.

Um espaço é de seguida consagrado ao sacrifício em Áulide. Agamémnon é forçado à solução de um dilema e faz a sua primeira escolha: a vitória sobre Tróia em troca da vida de Ifigénia. $O$ sacrifício cercou-se de violência, onde foi manifesta a resistência agoirenta da vítima e a crueldade do executante, o próprio pai. O coro não hesita em o classificar de 'impuro, ímpio e sacrilego' e em o denunciar como um acto culpado de Agamémnon. É o obscurantismo desta decisão que exige ao culpado um progresso até à luz, que Zeus não deixará de o obrigar a prosseguir mesmo sem a adesão da sua vontade. Com a afirmação da regra suprema da justiça divina, o coro silencia-se, na expectativa do que só o futuro pode revelar. Terminado o párodo, estão enunciadas as linhas de força de toda a trilogia, com uma maior amplitude do que aquela que os Persas tinham podido definir. $\bigcirc$ movimento imediato da peça, previsto pelo coro, terá de ser de violência e de punição, quem sabe se de ruína e de morte, tal como o que Xerxes percorre também. Mas neste caso há, para além do sofrimento imediato que a evidência da culpa exige, a promessa de uma redenção que fará brilhar, após um caminho de trevas, um clarão salvador.

A curiosidade é o sentimento que move o coro no questionário com que aborda Clitemnestra. Também os velhos iniciam o seu percurso em direç̧ão à

13 The Oresteia. A study in language and structure (Cambridge, Massachusetts 197I) 25. 
luz. Sóbrios mas insistentes, multiplicam as perguntas à rainha em busca de certezas, que são também a sua tentativa de calar apreensões (258 sqq.). A rainha promete alegria e esperança (266) e vai ganhando o entusiasmo dos seus interlocutores, apesar de alguma hesitação e resistência (268). As lágrimas, que o texto assinala, são por fim o sinal desse júbilo e sobretudo de lealdade e de dedicação (270-27I). É sob este sentimento de alegria que o coro escuta as novas da tomada de Tróia; a vitória é certa, mas talvez conseguida a custo de muita atrocidade. Clitemnestra não tem certezas sobre as etapas da guerra, só do seu resultado, mas suspeita justamente de alguns excessos que lhe são próprios. Por isso, o canto que se segue às suas previsões espelha uma ambiguidade que regressa (367-502). De início domina a celebração da vitória, não com a exuberância emotiva que os estímulos de Clitemnestra antes suscitaram, mas com uma análise mais racional e minuciosa. Por trás do êxito, o coro reconhece a mão de Zeus, não a do deus da plena sabedoria, mas do deus xenios, o guardião das obrigações devidas aos hóspedes. A vitória ganha tem uma parcela de justiça, a reparação devida a Zeus xenios, e essa produz alegria, moderada embora (355-402). Porque mesmo se justa, essa conquista não foi isenta de um preço que os Gregos tiveram de pagar: a todos os lares, a partida de Helena e a campanha de reclamação que exigiu trouxe sofrimento e luto. Também para a morte que infligiam a Tróia, os deuses cobravam, no luto argivo, preço equivalente (429-43I). E de repente a alegria recua, para dar lugar a uma reflexão serena, mas dolorosa, em que o coro deixa o lado do vencedor para se situar do lado da população que rega a vitória de lágrimas e antecipa o desfile do vencedor do cortejo fúnebre dos mortos em combate. Eis que os velhos falam de novo de angústia (459-460) e daquela cólera que a exigência do sacrifício de Áulide já antes Ihes tinha sugerido. Tantos outros sacrifícios e baixas ocorridos em torno da cidadela troiana prometem outras iras, sufocadas mas vigorosas, a perturbarem a festa do regresso. Assim o canto termina em dúvida, feita de prazer e de dor ao mesmo tempo. Uma pergunta se impõe: qual é de facto a verdade do facho que brilhou sobre Argos, portador silencioso de notícias (475-487)? As certezas dos velhos recuaram, depois que a razão se sobrepôs à emoção e veio afinar, nas suas verdadeiras linhas, o retrato da guerra.

Será um arauto a prometer, com a narrativa exacta dos factos, uma reacção decisiva, de alegria ou de desolação. Mas a garantia de um sucesso cruzado de tanto sofrimento não produz nos velhos, desta vez, nem sequer um júbilo moderado. À medida que a certeza do sucesso se vai consolidando, 
por estranha ironia cresce também com ela a apreensão do coro. $O$ seu esforço de aprender não obtém o efeito desejado, que traga aos espíritos repouso; bem pelo contrário, a crueza de uma guerra excessiva, penosa para vencidos e vencedores, vai derramando sobre o povo de Argos, que os velhos representam, um temor gélido a cada notícia mais consistente. As palavras conflituosas exprimem as contradições interiores; é 'doce' a aflição que se apoderou dos velhos (542), na ausência dos guerreiros - feita de esperança e de angústia. Mas agora que a revelação chegou, o coro sente-se rendido (583) ao peso da evidência, mas ainda assim incapaz de adoptar o comportamento festivo que a circunstância impunha.

É neste estado de desalento que os velhos acolhem Agamémnon (783809), impelidos por respeito e lealdade ao rei, mas incapazes de um aplauso entusiasta. Predomina a sinceridade, que deixa evidente a apreensão por trás do sucesso. Argos sofre e seria hipócrita ocultar sob sorrisos reverentes essa realidade. Mas o coro, que não deu ao projecto e ao seu artífice uma adesão plena, não deixa de se lhe juntar na hora do regresso. Não por um sentimento de alegria, mas por uma verdadeira dedicação devida ao soberano pelos súbditos que Ihe são leais. É particularmente austera esta reacção do coro, a quem bem ficaria, como aos conselheiros de Susa, o nome de Fiel, porque sincero na discordância mas constante na devoção.

São estes mesmos sentimentos que despertam mais uma vez a angústia no coro, depois de assistir ao acolhimento caloroso prestado ao vencedor por Clitemnestra. Algo soa a excessivo no júbilo e na homenagem gritante da púrpura, quando os velhos tinham alertado para a falsidade dos aplausos e dos sorrisos. $O$ coro auto-analisa o seu estado de espírito e interroga-se sobre os seus temores incompreensíveis (975-1034). As perguntas sucedem-se; angústias e suspeitas acumulam-se; e o coro atónito insiste no 'porquê', como se o seu enigma mais sensivel fosse o de se compreender a si próprio. Sobre a razão domina agora o coração, à evidência sobrepõe-se o sabor da profecia que apaga todas as esperanças. Há, no sentir profundo da sua alma, uma espécie de instinto poderoso, que para além de toda a racionalidade se declara verídico e temível. Os velhos travam a luta derradeira com o dilema que os aflige em toda a tragédia, o que é também a sua aprendizagem pelo sofrimento até à revelação final. Em definitivo o medo vence e arreda a esperada alegria. Os acontecimentos irão seguir este mesmo percurso e justificar a opção que os velhos fazem sob o efeito impulsivo da sensatez que lhes é própria. 
É lento o caminho que o coro percorre até à compreensão plena das suas suspeitas, que progride da surpresa e ignorância até à revelação. Cassandra, a vidente inspirada por Apolo, antecipa em tons diversos o futuro a que o palácio vai assistir, de sangue e de vingança. Aos gritos enigmáticos e tresloucados da Troiana, os velhos respondem com piedade, mas com total incompreensão também. As alusões aos crimes que no passado ensanguentaram a casa dos Pelópidas, reconhecem-nas e percebem-nas; mas aquelas que anunciam um novo caudal de sangue desconhecem-nas e receiam-nas. Da rejeição e ignorância, o coro vai passando ao susto e à previsão do infortúnio; o ritmo do seu canto avança, nesta cena, de uma tranquilidade indiferente, ainda que solidária, para um crescendo de aflição. Todos os sentidos se lhe mobilizam perante o tom lúgubre do canto de Cassandra, e aquela imagem de tom amarelado que lembra o sangue toldado de morte. Por fim as dúvidas dissipam-se em nome de uma evidência aterradora, mas inegável.

Já os gritos das vítimas bradam do interior do palácio e o coro os acolhe numa incapacidade de agir, como é convenção na tragédia grega. Emocionado apenas, aguarda repartido em meras hipóteses de reacção, o momento de se defrontar com os acontecimentos ocorridos no interior do palácio. Segundo Kitto ${ }^{14}$, seria absurdo que a hesitação do coro fosse relativa a intervir no que parece ser o assassinato do rei; mas talvez de facto o coro tema uma espécie de coup d'état, cuja dimensão e perigosidade não é capaz de avaliar do exterior; aos assassinos, os velhos referem-se sempre no plural, e uma ameaça de tirania está-Ihes presente no espírito (|355-1357, |365). Dos seus movimentos descoordenados, que se tornam evidentes da própria distribuição individualizada do texto pelos coreutas, é perceptível a anarquia e confusão que se apoderou de Argos com a morte do soberano.

Ao coro cabe, a partir deste momento, verificar a veracidade de todos os sinais que conduziam a esta conclusão. Diante do curso dos acontecimentos, ele deve repetir e consolidar as noções adquiridas ao longo da peça: a responsabilidade individual que resulta de uma opção consciente pela violência, que é consentânea com a maldição a pairar sobre uma família, neste momento mais vistosa. Daqui se deduz a inevitabilidade da vingança. Resta, por isso,

14 Form and meaning in drama, 32-34, coloca diversas sugestões de justificação para o que parece ser inoperância do coro. 
lamentar aquele homem que travou uma guerra terrível por uma mulher para vir a desabar do pedestal do triunfo às mãos de uma outra mulher.

\section{Coros de Divindades}

Os coros de divindades revestem em Ésquilo um cuidado particular de caracterização e de movimento.Tornar visível e actuante um grupo de entidades abstractas ou míticas, marcadas por uma natureza diversa da humana e apenas existentes na imaginação de uma sociedade, representa para um dramaturgo um enorme desafio. $\bigcirc$ exterior deve revestir uma originalidade que salvaguarde o seu carácter próprio e projecte em tons fortes o sentido profundo que eles representam. Se simbolizam violência, perigo, morte, sofrimento ou, pelo contrário, delicadeza, solidariedade, debilidade, o seu carácter deve ser imediatamente perceptível pelo exterior que exibem. Movimentos e palavras, sobretudo os que comentam esse aspecto, são complementos relevantes de caracterização. Parece particularmente expressiva a forma como se apresentam em cena, criando efeitos de surpresa e de inesquecível teatralidade. E a partir desse aparato inicial, todos os processos que tendem a estabelecer contrastes entre a sua natureza particular e as outras personagens que as rodeiam são essenciais ao resultado dramático e cénico final.

É em terreno exótico e deserto, nos confins do território cita, onde, solitário, um Prometeu aprisionado se lamenta, que vai ter lugar a aparição das Oceânides, as etéreas filhas do deus Oceano que constituem o coro do Prometeu Agrilhoado. A sua vinda é cuidadosamente preparada. Preso dos rochedos, à vista do público, travado pela resistência das grilhetas, condenado a uma imobilidade longa e dolorosa, Prometeu é a imagem da solidão e de um sofrimento inerte, cuja revolta só as palavras são capazes de exprimir. Por testemunha resta-lhe tão só a natureza que o cerca. É portanto na mais profunda lonjura e solidão que, de repente, o coração do inimigo de Zeus palpita e o ritmo dos versos que pronuncia se acelera de acordo com essa mesma excitação (1|4-127) 15. A percepção da presença de alguém é

15 Taplin (Stagecraft, 250) chama a atenção para a variedade de metros líricos e recitativos e para a extensão do texto que prepara a entrada do coro. Surpresa é igualmente o facto de este anúncio ser cantado por um actor, que se antepõe à entrada do próprio coro em termos líricos. Do todo resulta uma técnica que sugere a usada por Eurípides com as suas conhecidas monódias. 
claramente sensorial, denuncia-se pelo som e pelo cheiro, sem que a vista participe ainda no seu registo. Maior é o mistério, naturalmente, e aquela curiosidade que se exprime em interrogações exaltadas. Porque preso, Prometeu está também limitado na sua capacidade de sondar o horizonte, mas algo na sensação que exterioriza lhe diz que um ente extraordinário se avizinha: um deus? Um homem? Um ser híbrido? A aproximação torna-se mais nítida pela clarificação dos sons que a acompanham; não se trata já apenas de um 'ruído', mas de um bater de asas que se aproxima rápido, fazendo silvar os ares. Com o prisioneiro, o público aguarda, escuta e finalmente vê ${ }^{16}$. Um coro de donzelas aparece sobre um carro alado, trazido pelos ares, para pousar nas alturas vizinhas do supliciado. Uma imagem vibrante atinge o auditório: ao lado do peso das cadeias e da imobilidade do prisioneiro, vibram asas leves, claras e livres, pés ágeis na sua nudez, que exprimem tudo aquilo cuja falta constitui o suplício de Prometeu: a liberdade e um movimento que tem por fronteira os limites do próprio universo (|37-|4|). O barulho que fazem é ensurdecedor, porque a velocidade constitui a sua primeira característica. Mas vêm como amigas e vão declarar-se desde logo a corporização da solidariedade e da simpatia. Além de contraponto ao próprio prisioneiro, elas são igualmente o antídoto dos deuses de violência e de punição, a Força e o Poder, que corporizam a ira dos deuses olímpicos a quem Prometeu deve o seu sofrimento. Cabe-lhes bem a natureza feminina, como símbolo que são de uma philia delicada, emotiva e capaz de partilhar a experiência de uma enorme dor. Percebemos que são dotadas para percorrer longas distâncias, que são sensíveis e atentas à força dos estímulos que levam os sons da violência à profundidade do seu antro. Mas as diligências que empreendem são benfazejas e a sua intervenção a de um socorro certo para quem sofre. Identificadas como símbolo de uma solidariedade generosa para com o sofrimento, as Oceânides entoam com o prisioneiro um diálogo lírico, onde com a revelação dos sofrimentos de Prometeu se intercalam os lamentos emocionados das donzelas. Em vez dos anapestos do párodo, o poeta prefere o modelo envolvente do coro e personagem em diálogo, para dar expressão imediata ao

${ }^{16}$ Continua a ser objecto de acesa discussão o que é de facto oferecido à vista do público ou somente aos olhos da sua imaginação (vide a síntese das principais questões na nota seguinte). Todos estes efeitos parecem esbarrar com o que, dentro das limitações actuais, julgamos ser a sobriedade de recursos do teatro grego. É portanto certo que uma boa parte do espectáculo é deixada por conta da expressividade do texto e da imaginação do público. 
que é a competência reconhecida das Oceânides. Do ponto de vista técnico, o coro vê no entanto reduzido o espaço que habitualmente lhe é dado. Antes de mais são as lágrimas que lhes inundam os olhos, ao registarem os sinais visíveis do sofrimento físico de Prometeu, que exprimem comiseração e revolta perante a vítima da injustiça divina. Mas, para além do sofrimento e da violência olímpica, as Oceânides registam também a irascibilidade e orgulho desafiador de Prometeu e pressentem a força de um conflito que opõe duas vontades excessivas. Da solidariedade, o coro passa ao temor, por consequências mais graves que se adivinham na sorte de quem é já uma vítima de iras superiores. De aliado, o coro passa a confidente, permitindo a Prometeu a confissão dos seus males e ao público o conhecimento diferido dos motivos profundos de tamanha dor. Quais os motivos do ressentimento do Titã para com Zeus ficam então patentes; depois de ter posto ao serviço do Crónida o seu conselho, que valeu ao deus a vitória sobre os seus iguais e o domínio do universo, Prometeu tornou-se vítima da fúria do mesmo deus, quando protegeu a humanidade do seu plano de destruição. Uma espécie de monólogo de abertura retardado é proporcionado pelo calor emocional das Oceânides que vão constituir o interlocutor permanente do prisioneiro na solidão a que está condenado. Embora parecessem opostos na aparência e atitudes, Prometeu e o coro tornam-se próximos na ousadia e na oposição que, em tons diversos, declaram à autoridade de Zeus. OTitã, mesmo se preso, não perde a ousadia e manifesta toda a sua força nas palavras; elas, débeis mas livres de movimentos, estão aptas a exprimir todo o medo e revolta que as domina.

Só então, a instâncias do prisioneiro, as Oceânides baixam do carro (27I $-273)^{17}$. E esta mudança de atitude corresponde a um novo rumo na experiência de Prometeu: depois de terem escutado os acontecimentos passados, elas serão testemunhas dos males futuros. Com este movimento retardado do coro quebra-se qualquer monotonia possível numa tragédia

17 Sobre as questões cénicas colocadas pela aparição das Oceânides, vide M. L. West, 'The Prometheus trilogy', JHS 99 (1979) 136-I37; D. J. Conacher, 'The staging of Prometheus Bound' in Aeschylus' Prometheus Bound, 182-185; Taplin, Stagecraft, 252-260. São estes os principais problemas em debate: a forma de sugerir o carro voador que transportasse as Oceânides, o que exige alguma sofisticação cénica; o número de carros a usar por um único parecer insuficiente para transportar todos os elementos do coro; a definição de um local para a aterragem deste(s) veículo(s); a execução concreta ou a sugestão imaginativa como duas técnicas possíveis para garantir o efeito desta cena; a omissão, por parte de Oceano que chega a seguir, de qualquer menção à presença das Oceânides, suas filhas, em cena. 
onde o elemento visual é particularmente forte. As deusas baixam do carro, acentuando por palavras cada pormenor do seu movimento (277-283); das alturas aladas do carro e das rotas superiores dos céus, com pé leve, as Oceânides baixam à aspereza do solo. Ao descer das alturas do firmamento sobre a terra, elas de certa forma põem para trás a sua natureza de deusas para se aproximarem e partilharem o sofrimento dos mortais. A partir deste momento, o coro está pronto para uma solidariedade permanente, que se traduz em gemidos e lágrimas de amizade para o prisioneiro, e em palavras de censura para com a arrogância de Zeus. São também procuradoras da dor de Prometeu, que proclamam nos seus cantos e para a qual mobilizam a solidão e a natureza envolventes; por sua intervenção, o mundo dos confins citas ganha vida, como se todo esse imenso espaço, pela sua voz, se erguesse em ondas de compaixão. É o mundo dos humanos que se abre, desta paisagem vazia de criaturas sobre a Ásia inteira, mobilizada em volta do seu protector, Prometeu. A compaixão que confessam pelo prisioneiro é extensiva àqueles que com ele partilham a mesma perseguição divina, como é o caso de lo. Perante o sofrimento que o destino reservou aos mortais, as Oceânides comovem-se, mas sem perderem a sua identidade de deusas. Elas lamentam e choram, mas o olhar que lançam sobre a dor humana é exterior e algo distante, ferido pelo espectáculo que a tragédia humana provoca, como uma realidade nova e desconhecida no quotidiano pacífico e claro das divindades

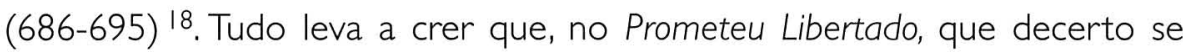
seguia ao Agrilhoado na trilogia, existia também um coro de divindades, os Titãs (fr. 193 Radt), talvez com o mesmo carácter de simpatia e de ineficácia que é o das filhas de Oceano. Aí ao coro era dado, ao que tudo indica, abrir a peça com uma sequência de anapestos (frs. 190-192 Radt), onde, depois de se referir à chegada, relatava o itinerário por si percorrido.

Oposta à das Oceânides é a natureza das Erínias e a sua missão no universo. Como deusas das trevas, vingadoras do sangue derramado, elas são entidades tenebrosas, sombrias, de visão aterradora. É sua função perseguir os mortais culpados de morte, ao serviço das suas vítimas. Sem deixarem de ser deusas justiceiras, representam no entanto uma legalidade primitiva, fundada na

${ }^{18} \mathrm{~A}$ um certo empalidecimento da actuação do coro nesta peça junta-se uma redução no espaço de intervenção que the é concedido. É-lhe retirada, por exemplo, a competência de expandir, com contributos míticos, o plano geral da criação dramática. Uma e outra circunstância constituem factor de polémica na eterna questão da autenticidade do Prometeu Agrilhoado. 
violência e obediente à regra de 'quem feriu tem de pagar'. Nessa medida a sua presença traz sombras, a sua imagem é assustadora, o seu relacionamento com os homens baseado no terror. São estas as Erínias que percorrem a última peça da Oresteia e que foram responsáveis por uma apate que testemunhos antigos documentam. Envolvidos no terror que a cena inspirava, os espectadores de Ésquilo experimentaram extremos de sensações que justificaram até abortos em criaturas sensíveis.

É muito cuidada a estratégia da sua aparição. Elas não vêm de fora, da luz ou das alturas; mas como deusas das trevas vão surgir do interior e das profundezas do sono. Ocultas dentro do templo de Apolo, o deus délfico da luminosidade, elas são uma mancha palpável dos horrores do crime à espera de ser contagiado pela toque redentor da luz. A impressão primeira que elas causam é visual; mesmo antes de se defrontar com elas, o público vê-as pelos olhos da sacerdotisa de Apolo. E não se trata de miragem ou de visão profética, mas da reacção exuberante causada pelo espectáculo concreto das Erínias, 'terríveis de descrever e terríveis de ver' (34). O impacto produzido sobre a Pítia é um estímulo à reacção forte do auditório. Em retirada do templo, sem forças, exangue, lenta de movimentos, a sacerdotisa narra em tons escuros o quadro, de linhas estáticas, a que só ela por enquanto teve acesso. As Erínias dormem, dobradas ao cansaço da perseguição de um Orestes ainda coberto do sangue da sua vítima; na atitude de um suplicante, que se sucede ao momento do golpe criminoso, Orestes segura ainda a espada ensanguentada, enquanto na outra mão sustenta um ramo de oliveira envolto em fitas brancas de lã. $O$ vermelho e o branco são as cores do seu destino de vingador à procura de paz.

Mesmo se paralisadas, a proximidade a que se encontram do criminoso não esconde a sua competência de perseguidoras; mas nem por isso a primeira imagem que produzem é menos estranha. São seres dúbios; embora com contornos femininos, elas não são humanas, mas mais parecidas com Górgonas (cf. Coéforas 1048); apesar de tudo, se comparadas com as verdadeiras Górgonas de que a pintura fixou o retrato convencional, elas são diferentes $(46-5 \mathrm{I})^{19}$. À memória da Pítia vêm também as Harpias consagradas pelo retrato mítico de Fineu, o rei trácio, a quem os deuses reservaram uma temível punição.

19 A forma convencional na pintura de representar as Górgonas atribui-lhes um rosto largo e disforme, com uma boca enorme e aberta, sem dentes e com a cabeça envolta em serpentes. Diferem das Harpias, que têm uma face próxima da humana, mas são aladas. 
Obscurecida a sua clarividência de profeta pela cegueira, os olímpicos fizeram dele uma espécie de Tântalo, a quem as Harpias roubavam ou conspurcavam os alimentos (frs. 258, 258a Radt) ${ }^{20}$. Por trás das primeiras tentativas de descrição pela negativa - 'não têm asas', Euménides 5I, nem são mulheres, nem Górgonas nem Harpias - está evidente a estranheza destes seres que não têm no que se conhece, entre as criaturas humanas e os monstros, uma possível comparação. Apolo (69-70) e Atena (4I0-4I2) partilham de idêntica impressão. Uma imagem ganha corpo nas suas linhas de sustentação: antes de mais pela cor, são negras (Coéforas 1049, Euménides 52); logo pelo aspecto geral, são 'asquerosas' (Euménides 52). Depois o som que produzem no sono, 'roncam', e o odor nauseabundo que o seu corpo exala (53); dos olhos brotam-lhes lágrimas terríveis de sangue (54; cf. Coéforas 1049); os acessórios que lhes caracterizam o exterior, as serpentes (Coéforas 1049-1050), são-lhes exclusivos, porque estranhos aos homens e aos deuses (55-56). Elas são portanto a excepção, entidades dos ínferos, cuja presença repugna ao universo. Pelas palavras da Pítia, todos os sentidos são mobilizados para uma rejeição unânime. Melhor do que a visão, a descrição sistematiza todas as nuances de um quadro que tem cor, som e cheiro. A sugestão está criada e preparado o contexto conveniente à sua aparição, quando a porta do templo se abrir de par em par. $\bigcirc$ que no testemunho da Pítia é uma impressão, na voz firme de Apolo é uma interpretação. Para além das evidências exteriores, em que o deus não insiste, o senhor de Delfos acrescenta das Erínias uma identidade completa (67-73). A quietude das Erínias é artificial e momentânea, provocada pelo deus que as dominou pelo sono. Dobradas e inofensivas, não é uma imagem de paz e de tranquilidade a que transmitem. Elas são malditas, velhas de uma idade sem tempo, primitivas e ferozes, a imagem viva do terror. $O$ seu terreno são as sombras do além, o reino onde domina o mal, como uma espécie de exlio para onde as relegaram as vontades dos deuses e dos homens. É para esse universo tenebroso que arrastam as suas presas. Com este retrato, Apolo coloca este coro de Erínias numa posição de isolamento em cena, onde não cabe um diálogo de harmonia e de colaboração onde elas participem com deuses e mortais. Elas são uma força agressiva e incómoda para todos, que será necessário controlar e cativar para um convívio civilizado.

20 Ésquilo dedicou a este mito a tragédia Fineu, composta em 472 a. C., que poderia ter sido uma oportunidade para o poeta encher a cena com o retrato dos monstros supliciadores do seu herói. 
Apolo não tem com elas um diálogo que permita essa aproximação. Dobra-as por uma força que Ihes é exterior, atraiçoa-lhes os intentos permitindo a fuga da vítima que perseguem. Não há, portanto, com o deus de Delfos, qualquer vaga aproximação. As sombras e a luz são, de facto, no temenos sagrado, incompatíveis. É para Atenas, a cidade patrocinadora de uma outra luz que advém do voto, do exercício da justiça e do poder do argumento que Apolo remete a solução desta incompatibilidade irredutível, como se o deus exigisse para $\circ$ esclarecimento de um caso de legalidade a participação vinculativa dos seres humanos em progresso civilizacional.

Estimuladas pelo fantasma de Clitemnestra, a sombra de uma vítima a reclamar vingança, as Erínias iniciam um lento despertar. A seu modo elas chegam, do fundo das trevas e do sono, para recuperarem passo a passo o vigor tenebroso de que são dotadas. De sonolentas a activas, as Erínias ascendem do fundo das trevas à superfície da terra e oferecem-se aos olhos atónitos dos mortais ${ }^{21}$. Dos roncos profundos, elas passam aos gritos estridentes, e destes ganham enfim uma voz que é um apelo à acção. Uma a uma lançam o seu protesto pelo logro com que os deuses ofenderam a sua prerrogativa secular. Primeiro picadas pelo protesto de um fantasma, é agora a traição que as espicaça, ao verificarem a ausência da sua vítima; as deusas agitam-se num desentorpecer progressivo dos membros. Trémulas de fúria, vibrantes de ódio contra o santuário que deu protecção a Orestes, vêem-se expulsas pelo deus e assim empurradas para o movimento que lhes é próprio: a perseguição.

$O$ reencontro entre o criminoso e as deusas da vingança ocorre, como previsto, em Atenas. Já Orestes, com os seus errores purificado do efeito forte do sangue derramado, envolve com braços de suplicante a estátua da padroeira da cidade, quando as Erínias aparecem de novo. Com a mudança de cenário é proporcionada às deusas vingadoras uma segunda entrada ou aparição. Mesmo se a ideia de perseguição é permanente, porque a presença de Orestes o assinala, desta vez a actuação das deusas é movimentada. Bem despertas de um sono que por um tempo lhes bloqueou os sentidos, elas entram agora com o nariz preso ao cheiro do sangue que perseguem (244-247). Gestos de cansaço, a respiração ofegante, exprimem a noção de uma longa corrida a separar Delfos

21 Taplin (Stagecraft, 37I-372)acentua o efeito particular resultante de adiar a aparição das Erínias em cena. Na sua leitura, o despertar das deusas ocorre no interior e dele nos chegam apenas os sons. Assim se cria uma tensão que vai tornar a presença adiada das Erínias verdadeiramente fulminante. 
de Atenas. Ligeiras e persistentes em ultrapassar todos os obstáculos, as deusas terríveis fixam-se no faro e guiadas por ele persistem para além de todos os limites. Certas da proximidade do seu alvo, elas passam a inspeccionar com a vista, perfuram e esquadrinham com os olhos até vislumbrarem de novo a sua presa (255-256). Uma alegria tenebrosa as anima. Possivelmente repartido entre cada coreuta, o canto que se segue (259-275) permite visualizar o cerco que se aperta em torno do fugitivo. Agarrado à estátua de Atena, seu último refúgio, Orestes ouve as deusas sugadoras de sangue que insistem na sede, na ânsia de uma bebida que lhes anima a existência e que é a prova da consumação do castigo. Esta é a imagem das Erínias em plena função de entidades raivosas da vingança. Em crescendo angustiado, Orestes persiste na súplica, enquanto as Erínias iniciam em seu redor uma dança de morte (307-320), que é a última etapa na sua transformação visual em cena: de entidades abstractas em seres concretos, que passam a constituir expressamente o coro da tragédia (307-309): 'Vamos, formemos um coro, que é tempo de tornar visível o poder da nossa música'. Este é um momento de enorme efeito na expressão palpável do divino e na relação entre as palavras e a sua concretização visual.

Numa cadeia dançante, as filhas da Noite bradam os seus direitos, num novo conflito de autoridades; por trás da criatura humana perseguida, uma outra deusa, Atena, é confrontada com o poder das Erínias, de modo que uma outra ordem cósmica se apresenta como necessária. Progressivamente mais ágeis, as Erínias vão-se deixando vencer pelo delírio. $\bigcirc$ ritmo, para além das palavras, é sinal da vivacidade crescente da dança. Por entre um longo recitar dos atributos ancestrais, as Erínias integram no seu canto as próprias marcações da dança que executam, onde a insistência nos verbos de movimento assinala cada gesto. $\mathrm{O}$ uso de um refrão é um elemento decisivo no efeito geral do canto e da dança (329$332=340-345 ; 354-359=366-368)$. É com estes versos repetidos que o coro marca o ritmo, acentua a vertigem, acelera o movimento até ao delírio. Esta é uma espécie de ritmo encantatório, que paralisa de susto os mortais e os rende, indefesos, ao seu destino. Reforçadas na sua vitalidade, as Erínias saltam cada vez mais alto para recaírem com mais peso, num sinal de esmagamento e de aniquilação total de uma vítima perante o seu poder mortífero. Elas transformamse, nas palavras felizes de Y. Prins ${ }^{22}$,'numa maldição actuante e corporizada'.

22 'The power of the speech act: Aeschylus' Furies and their binding song', Arethusa 24 (1991) 188. 
Só a aparição magnífica da deusa Atena consegue acalmar este excesso sangrento das Erínias e abrir, nas suas legítimas reivindicações, um espaço de juízo e de reflexão. Mas o resultado de um julgamento que lhes é adverso vai estimular de novo a sua fúria (777 sqq.). Não é já o réu absolvido o alvo directo da sua ira, mas uma nova ordem divina, que vem fazer frente às suas prerrogativas ancestrais. Num longo epirrema, Atena vai desenvolver uma táctica de sedução e de acalmia das velhas filhas da Noite. O processo segue agora um sentido inverso, da fogosidade ao adormecimento da fúria das deusas. Sob o efeito de uma ofensa divina de que se consideram vítimas, elas ameaçam o solo que pisam de poluição e gemem sem cansaço sobre a humilhação que as penaliza. À emoção que as toma, Atena responde com lucidez e com argumentos convincentes, oferece-lhes outras homenagens que as compensem, num critério diverso de ordem universal dos poderes abalados. $\bigcirc$ recurso a outro refrão (778-792 $=808-823 ;$ 837-846 $=870-880$ ) exprime a renitência obstinada das Erínias. É-lhes dolorosa a ruptura iminente dos seus poderes, enquanto uns laivos de cólera persistem em alimentar-lhes a cólera vingativa. Mas por fim a deusa vence, a cólera irredutível das Erínias cede diante da generosidade com que Atenas Ihes franqueia um acolhimento reverente. $\mathrm{Na}$ cidade da justiça, elas reinarão como deusas dignas de todas as honras, dentro de uma nova ordem onde perdura, em vez do sangue, a paz, na equidade, na luz e na bem-aventurança. De Erínias, as deusas convertemse em Euménides, entidades protectoras e benfazejas; conciliadas com Zeus e Dike e detentoras de uma autoridade que não só garante a ordem cívica, mas também a universal. Por isso a retirada final é a imagem de um ritual sacro e solene como convém a um novo símbolo da divindade (1021 sqq.). Em réplica do verdadeiro rito ateniense de homenagem às Erínias, organiza-se o cortejo, onde abunda a luz das tochas. As trevas rodeiam o ritual, a procissão dirige-se para espaços subterrâneos, mas uma luz brilhante impede que as trevas se adensem outra vez. Uma escolta de sacerdotisas de Atena, juntamente com a população de mulheres da nobreza, de crianças e de anciãs, forma um acompanhamento piedoso, num ritual claramente feminino. A riqueza dos trajos e o brilho das púrpuras criam uma solenidade propícia e favorável a uma prosperidade que as novas deusas patrocinam. Um silêncio recolhido cai sobre a cidade em festa, até que o grito ritual, em resposta ao tom solene do canto, dá uma expansão plena à intensidade de um sentimento que promete libertação de cuidados e a alegria de uma paz esclarecida. 
Personagens 
(Página deixada propositadamente em branco) 


\section{A expressão do transcendente em cena}

\section{Deuses}

Falar de deuses em cena no teatro de Ésquilo significa, em relação à presença divina em cena na tragédia grega, algo de particular. Não se trata apenas de reservar aos deuses uma intervenção final ex machina para solucionar uma intriga que se não resolve somente por mãos humanas, nem de tornar palpável, na presença de um deus, o que até então tinham sido forças actuantes em abstracto. Os deuses em cena no teatro de Ésquilo são verdadeiras personagens, com um papel que se vai desenvolvendo ao longo da peça. Nesse contexto, os deuses contracenam com os mortais, mas sobretudo representam, nos conflitos que se desenvolvem entre eles, o contencioso de forças ou princípios que regem a ordem universal. As peças que contam com a sua actuação directa são, por definição, grandiosas e universais, no que se refere aos efeitos de cena imediatos e aos grandes temas que trazem à discussão. Mais do que quaisquer outras espelham com visibilidade os grandes princípios que regem a ordem cósmica e a sua conflitualidade e clarificação progressiva. E fazem-no com um aparato cénico notável de acordo com o princípio defendido por Ésquilo nas Rãs (|058-106|) de Aristófanes, de que a grandes temas convêm personagens elevadas, um discurso magnificente, atitudes e trajos majestosos e efeitos de cena espectaculares. Este é sem dúvida o contexto de excelência para o poeta pôr à prova as linhas mestras de uma personalidade dramática onde a grandiosidade, de acordo com o crítico de Rãs, dava o tom geral.

O Prometeu Agrilhoado é, deste modelo, um exemplo vistoso. A peça aborda um conflito de forças divinas, aquelas que trouxeram ao domínio do universo uma geração recente de divindades de que Zeus é símbolo (199-2/3). Ganho pela violência esse domínio, com o contributo de uma estratégia subtil de que Prometeu foi artista, a nova ordem divina quis assegurar a supremacia 
com uma estabilidade que rapidamente denunciou uma arrogância injusta. Para com as outras divindades, como para com os mortais, Zeus adoptou um procedimento de conflituosidade e de intolerância, que gerou contestação em torno da sua autoridade. $O$ poder que exerce não obedece a padrões gerais e incontroversos, não está portanto instituído (150), mas tem carácter privado, pessoal e logo tirânico (403). Nessa luta, que significa um processo de procura de uma ordem geral mais justa, mais próspera e mais equilibrada, Prometeu ocupa o papel da oposição à prepotência divina, como um deus capaz, pelo engenho e pela lucidez, de pôr travão aos excessos dos olímpicos e de garantir aos mortais uma dignidade legítima no projecto universal. Porque a causa era de um alcance extremo, os conflitos que a acompanharam têm também o recorte de uma dimensão paradigmática.

O prólogo da peça cumpre em plenitude o que se espera da sua função, registando todas as linhas mestras do motivo dramático. $O$ conflito divino e os extremos de violência a que conduz sobressaem desde logo da qualidade das personagens em cena, não menos de quatro: a autoridade ausente de Zeus, com toda a sua sobranceria e excesso, tem representação em duas alegorias, - Poder e a Força, como agentes concretos na actuação do poder olímpico contra os opositores. O prisioneiro que conduzem é modelo de uma contestação radical à ordem vigente. Por fim Hefesto, repartido entre o compromisso para com uma ordem superior e alguma comiseração pelo prisioneiro por laços de parentesco e afinidades de função, encarna a indefinição de uma ordem universal a aguardar ainda uma reflexão redentora, mesmo se acompanhada de dor, a caminho de um novo rumo civilizacional. $\bigcirc$ que, do ponto de vista temático, é oportuno deixa em aberto uma opção cénica única nas tragédias conhecidas: a entrada simultânea de quatro personagens, com identidades próprias, no início da peça. O próprio ambiente onde a aç̧ão tem lugar - os confins extremos, vazios e desconhecidos da Cítia - conduz este conflito para uma espécie de limbo ou terra de ninguém, onde deuses e homens se encontram fora dos seus domínios naturais, à procura de um terreno neutro onde possa ser encontrada a chave para uma reordenação fundamental. A missão que aí reúne estas forças divergentes exprime com clareza a repartição imediata das entidades em conflito: a oposição a Zeus em que Prometeu se aposta está ainda sujeita à superioridade, primitiva na sua violência, do Crónida. O poder olímpico está em vantagem e, pelo uso de uma estratégia de agressividade, apostado em dobrar a resistência. Qual o sentido 
dessa autoridade vigente, baseada numa prepotência irracional e contestável, está expresso na tirania sobre o prisioneiro que vai ser agrilhoado e condenado à prisão e à tortura. É este o tratamento que a autoridade suprema do mundo reserva a quem se lhe não sujeita passivamente. Para além da presença viva do Poder e da Força, a exuberância cénica do agrilhoamento traz à medida do concreto, no plano visual e auditivo, o sentido da tirania. Hefesto, apesar de dividido nas suas convicções, exibe as insígnias tradicionais do deus da forja, que são também, no contexto actual, instrumentos de tortura. Nas alturas inóspitas das montanhas abruptas, cadeias inquebráveis de aço vão encadear o vigor físico da contestação (4-6). O castigo tem a simbologia de uma espécie de pena de talião, porque é pelo fogo, que Prometeu roubou a Zeus para o dar aos mortais como uma vantagem que os fizesse partilhar da superioridade distante dos deuses, que o ferro será dominado à medida de uma grilheta punitiva (78). Com esta medida extrema de aniquilação de um contestatário, o Crónida defende os princípios de uma ordem radical que vê abalada: aquela em que aos deuses compete uma superioridade absoluta e inquestionável, em confronto com o universo bestializado dos humanos. Qualquer diálogo ou comunicação entre os dois universos está ausente deste projecto (I0-I I).

A primeira brecha neste modelo radical percebe-se nas facções em que se vão repartindo as divindades. Mesmo se obediente às ordens de seu pai, o próprio Hefesto dá voz a uma discreta discordância. Sob um sentimento de solidariedade para com um outro deus sujeito a um castigo por assumir uma posição arrojada e frontal (14-17), o deus do fogo patenteia indícios mais brandos de recusa a um domínio baseado na violência que ofende os mais ténues princípios de cooperação e de harmonia universal. A insistência na menção das grilhetas de aço que irão aniquilar a resistência de encontro aos rochedos poderosos da montanha (19-20), como um castigo exemplar, constitui uma chamada de atenção preparatória para uma acção que será executada muito em breve com o máximo aparato cénico. Às cadeias vão aliar-se os instrumentos de tortura que, tal como as alegorias do Poder e da Força, concretizam os que são os atributos tradicionais da autoridade olímpica. $O$ sol, com toda a sua potência de insígnia do senhor da luz, irá aniquilar, de forma irreversível e lenta, os humores vitais do prisioneiro (22-27); ao seu poder destrutivo virá juntar-se a águia divina, que lhe devorará, ao longo dos séculos, o fígado, um órgão simbólico de vitalidade (I02|-1025). Assim o Crónida ameaça reduzir, para a eternidade, a reacção bem sucedida ao seu poder autoritário. À 
mesma tela, a previsão de Hefesto acrescenta a imagem do supliciado, o benfeitor dos homens: de pé, sujeito a uma insónia eterna, ele lançará para uma solidão hostil os seus lamentos sem que a esperança de um abrandamento tenha lugar. São estas as cores da tirania celeste, dureza, impiedade e violência, a que o tempo sem limites traz o sentido do eterno e irremediável.

$\mathrm{Na}$ polémica verbal a que o prólogo dá voz, Prometeu não tem intervenção. Ele é uma personagem silenciosa, que se limita a ouvir o que os outros decidem ou sentem sobre a sua situação. Porque mais do que para a sua sorte é para os movimentos de opinião em torno de Zeus que o poeta canaliza as atenções, expressos pelo Poder, o procurador dos interesses agressivos do deus supremo, e por Hefesto, como voz de uma ténue dissonância. A Prometeu, neste quadro inicial, cabe o papel passivo de sofrer. É então que sobre ele os nossos olhos caem, para assistirmos a um suplício já anunciado (52-87). Membro a membro, elo a elo, as cadeias manietam a vítima da ira divina. A cada parte paralisada sucede-se o ruído decidido e sonoro das marteladas no aço que o firma. Com a competência que só o deus dos ferreiros detém, a tarefa é realizada em pormenor e com minúcia. Se alguns lamentos acompanham o suplício, não vêm dos lábios do prisioneiro que se fecha num silêncio ousado; é o próprio Hefesto, dividido entre a obediência e a discordância, quem os faz ouvir (66-68). Só quando os operários divinos, após cumprida a tarefa, se retiram, não sem que o Poder deixe a soar aos nossos ouvidos palavras de desafio à rebeldia, que finalmente o prisioneiro fala. Porque imóvel e incapaz de reagir pela acção, toda a força de Prometeu se concentra na arma que the resta, a palavra. $\bigcirc$ Poder, e com ele a autoridade que representa, nem mesmo suspeita dos recursos que ainda restam ao inimigo e que são, de resto, a sua verdadeira alma. Os elos da violência, que tanto orgulham o deus supremo e que são em si inquebráveis, não bastam para aniquilar a resistência; são mesmo um estímulo ao uso de outros recursos insuspeitos e por isso temíveis.

O protesto de Prometeu reveste vários tons, que denunciam as nuances de sentimento que o dominam. Em vez de lamentos, é com um apelo geral às forças do universo que ele começa a sua intervenção, numa mobilização de aliados mais compatível com a ideia de uma resistência que se não deixou abalar do que com a de uma cedência causada pelo sofrimento físico. Prometeu conhece superiormente as decisões do seu destino, e a essas sem revolta se submete. Mas porque elas resultam da injustiça inaceitável de um deus 
imperfeito não podem deixar de ser denunciadas. É nesta disposição de persistência que o vêm encontrar as Oceânides, as primeiras a mobilizarem-se junto de Prometeu como companheiras na solidariedade, na revolta e na oposição à prepotência divina. Para serem também as primeiras a conhecer o desfecho previsto para o conflito (167-177): um dia há-de vir em que Zeus precisará da intervenção do seu prisioneiro para preservar o seu poder. Nessa altura, o Crónida ver-se-á obrigado a recuar, restituindo o prisioneiro à liberdade e compensando-o do ultraje sofrido. Com esta profecia de que o próprio Prometeu é detentor, o movimento da peça muda de sentido: o que aparentemente era o remate posto a um gesto inútil de revolta é afinal um passo inicial num longo percurso que, mobilizando em torno da oposição ondas de solidariedade, irá culminar com a rendição da prepotência divina. Zeus não perderá a autoridade, mas conservá-la equivale a aceitar outras condições e a negociar com aquele que representa os interesses humanos e um novo equilíbrio para a ordem universal. Cada figura que irá desfilar perante o supliciado dará a este percurso a caminho da liberdade cósmica um contributo próprio e um sentido concreto.

O desfile inicia-se perante um Prometeu que a peça insistentemente identifica como um espectáculo de dor (241, 244-246, 304); a força cénica desta imagem de suplício tem o poder de denunciar a injustiça e violência dos que a determinaram; é portanto de alguma forma o resultado palpável da presença e da actuação de Zeus. Mas é também um estímulo à discordância e à solidariedade de quem a observa, um meio capaz de quebrar a solidão do prisioneiro atraindo-lhe as simpatias universais.

Se é espectacular a imobilidade do supliciado, não o é menos o visualismo e o movimento contrastante de cada um dos visitantes. Depois das Oceânides, é o seu próprio pai que aparece. Insiste-se na estratégia do voo. $\bigcirc$ deus chega sobre um grifo de asas rápidas, conduzido pela simples vontade divina (284-287) ${ }^{23}$. A situação de imediato identifica um deus e, com a declaração de Oceano de que é a compaixão que o move, reforça a ideia, já perceptível com Hefesto e as Oceânides, de que há dissidências entre os deuses em relação à questão candente: uma nova ordem cósmica. Oceano é a encarnação da philia,

23 A questão de produzir em cena o efeito do voo volta a colocar-se. Taplin (Stagecraft, 260-26I) considera que tudo aponta no texto para o recurso à mechane, o que suscita o problema de saber se ela é um recurso acessível ao teatro de Ésquilo ou se só passou a ser usada mais tarde. 
um sentimento de solidariedade que não é passivo, mas exige intervenção activa. A sua piedade não é meramente espectante, mas pretende ser interventiva. Exige-lhe, antes de mais, o conselho e uma avaliação prudente das forças em litígio. Porque são duas vontades extremas as que se opõem - 0 orgulho de Prometeu e a intolerância de Zeus -, o futuro anuncia-se ainda mais sombrio e doloroso, se não houver de algum dos lados um recuo de prudência. De Prometeu, Oceano solicita moderação nas palavras, enquanto do Crónida espera obter benevolência. Além de uma demonstração de fidelidade, o deus voador nada mais consegue do que tornar patente a tensão extrema de um conflito irredutível, que só uma crise ainda mais profunda poderá sanar. Os riscos que está disposto a correr junto da prepotência divina trazem à recordação de Prometeu o número de condenados por Zeus ao sofrimento e o risco inútil que correm todos os que procuram contradizer a vontade do pai dos deuses. Mas para além de justificar novas evidências da agressividade divina, Oceano assume o papel da resignação. No público vai-se consolidando a ideia de que um espectáculo de enorme violência irá ainda revestir tonalidades mais sombrias. Consciente dos perigos que correm os que ousam confrontar-se com Zeus, Oceano cede e retira-se tão simplesmente. É na peça modelo único de uma atitude passiva e indefesa para com a tensão universal reinante. Tão leve como a sua intervenção é a retirada (393-396); incapaz de dobrar a vontade forte de Prometeu, o deus retira-se nas asas do grifo a caminho da sua morada divina.

A entrada de lo, agitada pelo aguilhão do moscardo, ecoa e legitima a denúncia de Prometeu. A sua presença traz até aos confins da Cítia uma criàtura humana, a única actuante na peça, solidária com o sofrimento do prisioneiro, porque também ela vítima da prepotência olímpica. A verdade das palavras de Prometeu a Oceano torna-se concreta nesta princesa argiva, que, sem ter de forma alguma contestado ou ofendido o ascendente divino, é no entanto também sua vítima. $\bigcirc$ que move Zeus em relação a lo não é fúria, mas amor. No entanto, o contacto de Zeus com o universo exprime-se indistintamente em penalizações e violência, sem que a suprema noção de justiça, de prémio ou de castigo, regularize uma ordem desejável e esclarecedora. lo é portanto uma segunda vítima de Zeus, supliciada de uma forma diversa da de Prometeu, condenada a uma fuga eterna e desvairada, também ela à procura da redenção. Graças à capacidade profética do deus agrilhoado, mas detentor de uma notável lucidez, ganha corpo a ideia de que 
a libertação há-de chegar, para lo, na sua errância pelo Egipto e, através dela, para o próprio Prometeu que um descendente da donzela argiva, treze gerações mais tarde, há-de salvar; com mais precisão, o salvador é mesmo identificado com Hércules, 'o archeiro superior e famoso' (77I, 773, 87I-874). A ideia da libertação ganha mais consistência e desvenda-se em traços mais concretos. Com ela, a disposição de Prometeu muda sensivelmente. Mais seguro de si e certo da libertação, o Titã redobra de confiança e, ao mesmo tempo, de indignação e de desafio para com o seu adversário. $O$ tom do conflito muda, a partir deste momento, de forma clara.

É o momento de trazer, em voo do Olimpo, Hermes, o mensageiro de Zeus (94I-942). Solidário com o deus que o envia, Hermes é a voz da violência e a presença palpável do inimigo que persegue Prometeu. $\bigcirc$ tom da compaixão ou da compreensão, que Oceano e lo tinham imposto em cena, é substituído pelo insulto e pelo ressentimento. Mas por trás da insolência domina o temor, que faz das previsões de Prometeu uma arma credível e assustadora. Os deuses levam a sério as ameaças da sua vítima, mesmo se manietada. Prometeu reforça-se como imagem de vigor e de uma oposição divina, à altura de uma luta derradeira com os próprios senhores do Olimpo. $\bigcirc$ seu ascendente é o do espírito, é todo o seu saber que o torna temível, mesmo se o corpo está neutralizado. Com ele, um poder maior do que a força - o do nous - se anuncia, como prometedor de uma nova autoridade universal.

Falta ainda, porém, que o combate final seja travado. Prometeu usa até ao extremo a arma de que dispõe, a palavra, multiplicando as ameaças, os protestos de ódio e de desafio ao poder de Zeus. Se confrontado com o Prometeu silencioso do prólogo, que sem uma palavra suportava a agressão da ira divina, o Titã do final da peça estabelece, como diz Conacher ${ }^{24}$, 'a grande dinâmica da peça, as progressivas revelações em consequência do efeito dos visitantes sobre ele'. Não é a sua atitude para com Zeus que muda, mas a maneira de enfrentar a sua divergência com o Crónida e de gerir o conhecimento que tem de um segredo de que a sua sorte depende. Em termos gerais, no final do Prometeu Agrilhoado, a divergência das forças em litígio aprofundou-se. Ao destino junta-se alguma hybris, que desencadeia sobre ele mais um acesso da fúria divina. Já Hermes o antevê em toda a sua sonoridade ( 1007 sqq.), com a derrocada final da paisagem que circunda o prisioneiro: pela

24 Aeschylus' Prometheus Bound (Toronto 1980) 22. 
força do raio divino, as montanhas desabarão submergindo o corpo dominado de Prometeu. Sepultado sob as pedras, mergulhado em trevas por anos sem fim, aí aguardará de novo a luz que tarda. Para suplício maior, a águia de Zeus se encarregará de lhe devorar, em macabro festim, as entranhas.

Mesmo se a violência dá a vitória ao senhor do Olimpo, esse ascendente tem também a sua caducidade. Prometeu reconhece-lhe o poder, aceita-a como a realização inevitável de um destino, mas vai mais longe. Ao fim de um longo caminho de sofrimento, a redenção soará. Redenção adiada, porque já das palavras se passa à acção (1080). O terramoto ressoa das profundezas, raios e trovões cruzam o firmamento, os tornados abalam os céus; e Prometeu, tornado frágil na sua revolta contra Zeus, é submergido e silenciado sob as pedras, até que $o$ destino, no fim dos tempos, o redima. Em cena, o desenvolver da trilogia irá acompanhar este processo, que é de libertação para Prometeu; para o seu poderoso adversário, ele será decerto também uma experiência de esclarecimento e de aprendizagem, que o converte no garante da moderação e da justiça. Não é a natureza divina que muda, mas a relação entre os deuses e as grandes forças que regem o mundo no sentido de um outro padrão de convívio universal 25.

Para além do Prometeu Desmotes que conservamos, outras duas tragédias atribuídas a Ésquilo sobre o tema do Titã parecem constituir com ele uma

25 Sobre as diversas interpretações do sentido desta peça e em geral da trilogia a que pertence, vide S. White, 'lo's world: intimations of theodicy in Prometheus Bound', JHS I2I (200I) 107-109. Para este autor há que buscar na peça indícios de uma reabilitação para a imagem de Zeus, que temperem a crueldade e tirania que caracteriza o seu comportamento evidente, e o justifiquem com motivos visíveis nas entrelinhas da tragédia. Esta personalidade conferida a Zeus tem sido mesmo tomada como prova contra a autoria esquiliana do Prometeu, por retratar uma noção de divindade divergente do que parece ser o conceito geral de Ésquilo nesta matéria. Sobre a leitura do divino no Prometeu, é ainda útil o título de Conacher, 'The Zeus problem in the Prometheus Bound and the trilogy', in Aeschylus' Prometheus Bound, 120-137. Para além deste aspecto, outras questões foram consideradas como capazes de pôr em causa a autenticidade da peça: particularidades de métrica, estilo e linguagem. A somar a questões de ordem formal, acrescem as exigências cénicas que parecem obrigar a uma datação mais tardia da peça, ao mesmo tempo que se tornam suspeitas por parecerem gratuitas e ineficazes, para além da simples espectacularidade.

E, no entanto, é inegável o muito que há de Ésquilo na peça: a universalidade dos problemas e a natureza divina das personagens; ou a magnificência inevitável do espectáculo. Logo se as dúvidas não deixam de ser fundamentadas, as semelhanças com Ésquilo são todavia consideráveis. Dizer com Taplin (Stagecraft, 240) que se trata da produção de um admirador de Ésquilo que the segue o modelo, ou de uma criação inacabada do velho poeta que levou um 
trilogia: o Prometeu Libertado (Lyómenos), em que naturalmente a libertação do deus ocorria, e talvez a sua consagração como senhor do fogo no Portador do Fogo (Pyrphoros); mas esta matéria é bastante controversa ${ }^{26}$. Parece, no entanto, lícito pensar que o Libertado sucedia ao Agrilhoado, que retomaria o cenário e o contexto da peça precedente; apenas o tempo é outro, porque longos anos de cativeiro no Tártaro se passaram entretanto (frs. 190-192 Radt). Ou seja, o prisioneiro reaparecia ainda amarrado ao mesmo rochedo depois de ter sido submergido pelo abalo telúrico. No cativeiro, Prometeu continuava a receber visitantes solidários, muitos anos passados sobre o seu aprisionamento. Para além de Gê, a mãe do Titã, lá acorreria Hércules, o descendente de lo destinado a assumir a salvação de Prometeu (frs. 195-201). A menção das benesses concedidas pelo deus aos homens e a previsão das errâncias de Hércules pelas regiões do norte e do oriente parecem constituir matéria do diálogo desenvolvido com este visitante. Os dois últimos fragmentos desta série (200201) sugerem o momento em que, aniquilando a águia de Zeus pela força do seu arco, Hércules punha fim ao suplício do Titã. A peça terminaria possivelmente com a libertação e a reconciliação com Zeus. Enfim livre de cadeias, o Titã poderia, juntamente com os seus irmãos, abandonar o lugar de tortura.

As Euménides são igualmente uma peça confiada a personagens divinas, onde a Orestes é atribuída a única intervenção humana. No entanto, é em torno do matricida e das consequências do seu acto que várias forças divinas se movem em busca de uma justiça adequada. $A$ angústia que deixa o ser humano atribulado é remetida para causas superiores onde as vontades divinas

remate espúrio e tardio, são formas de conciliar o que parece uma evidência: que há diante de nós um Ésquilo que o não é por inteiro ou em exclusivo. À avaliação dos argumentos que alimentam esta controvérsia, dedica ainda Taplin as pp. 460-469 do mesmo estudo; e D. J. Conacher, 'Some views on the authenticity of Prometheus Bound', in Aeschylus' Prometheus Bound, 141-174. Na perspectiva deste nosso estudo, incluimos o Prometeu como esquiliano, seguindo de resto a prática dos melhores estudos sobre Ésquilo.

26 É particularmente discutível a autenticidade e a temática desta última tragédia, porque os vestígios conservados permitem todas as especulações. Cf. A. D. Fitton-Brown, 'Prometheia', JHS 79 (I973) 52-60; M. L. West, 'The Prometheus trilogy', JHS 99 (1979) I30-I48. Para aqueles que admitem a sua existência, é ainda controversa a posição que ocupava na trilogia. Aqueles autores para quem o Pyrphoros vem no fim, consideram a peça um aition dos Prometheia áticos, um festival de tochas que Atenas dedicava a Prometeu, o que parece todavia matéria insuficiente para uma peça completa. Se se lhe der a posição inicial na trilogia, o assunto poderia ser o do roubo do fogo, o que traria ao conjunto um sentido coerente de prevaricação / castigo / reconciliação. 
ponderam. A. Lebeck ${ }^{27}$ valoriza o carácter dinâmico desta peça que envolve mudanças rápidas, de cenário, de circunstância e de normalidade, com a própria mudança de critério na ordem superior que rege o universo. É portanto um momento crucial na evolução de um conceito de justiça a que opõe as divindades antigas e as suas prerrogativas ancestrais aos deuses olímpicos mais recentes. As Erínias, como deusas habitantes das sombras e procuradoras das vítimas de crimes de sangue, representam um princípio ancestral inspirado na regra 'quem agiu tem de pagar'. O seu ascendente assenta portanto na obrigação de cobrar com o sangue o sangue derramado. Depois que o solo se encharca dos fluidos da vítima, as velhas deusas, de aspecto medonho e de perseverança incansável, desencadeiam a perseguição contra o assassino que háde lavar, com o seu próprio sangue, a mancha que causou. Por isso as Euménides abrem com um quadro de vingança. Orestes, exausto e assustado, acolhe-se ao templo de Delfos e à protecção do deus que lhe ordenara o matricídio, enquanto em volta as Erínias repousam num breve momento de trégua. Mas já o fantasma de Clitemnestra se Ihes infiltra no sono a reclamar vingança.

Esta justiça antiga e violenta que as Erínias representam tem nesta peça opositores nos deuses olímpicos mais recentes. Deles a autoridade suprema compete a Zeus, representado em cena por dois dos seus filhos, Apolo e Atena. Com uma nova ordem cósmica, cada um dos deuses traz à peça uma noção superior. Apolo opõe às trevas, de morte e de vingança que as Erínias representam, um mundo de paz, de luminosidade e de pureza, de onde se exclui tudo aquilo que as deusas das trevas simbolizam. $O$ próprio Apolo se assumiu como senhor do seu santuário sem ter de recorrer à força, mas por uma cedência pacífica entre as divindades que sucessivamente o ocuparam (I-II). Logo a serenidade do lugar é profunda, porque constitui uma regra inviolada em toda a sua existência. Em Delfos reina já uma harmonia de deuses ctónicos e olímpicos, como um projecto antecipado daquele a que o desfecho da peça irá conduzir. A oposição do deus délfico em relação às deusas da vingança é activa e peremptória. É por acção do senhor da luz que elas dormem, quebradas as forças que as movimentam na perseguição de Orestes. Sem um momento de cedência ou de tolerância para com as Erínias, Apolo mantém-se o protector fiel do filho de Agamémnon, cujas mãos procura purificar. Uma longa errância, sem desistência perante a perseguição incansável

27 The Oresteia, 134. 
das Erínias, é uma provação que o matricida tem de sofrer como ritual de purificação. Errância que há-de terminar em Atenas, cidade da justiça e da persuasão, onde a deusa padroeira presidirá a um julgamento capaz de pôr fim à expiação redentora de Orestes. Solidário com as ordens olímpicas, Hermes, o mensageiro dos deuses, será o companheiro seguro e protector do herói fugitivo. De Delfos, os nossos olhos colhem uma imagem preparatória do julgamento: de um lado o transgressor e o deus que o protege, do outro a vítima que desperta as suas vingadoras. Mas o confronto directo é adiado para o cenário judicial de Atenas. E se a sua intervenção despoluidora do sangue derramado não contenta as perseguidoras, o deus não hesita em expulsar do seu templo as filhas indesejáveis das trevas.

Não sem que antes um primeiro debate se trave entre as duas forças divinas, cada uma delas animada por uma legitimidade justiceira. $O$ castigo que as Erínias propõem e recomendam é cego, não conhece tolerância nem piedade. Sangue lava-se com sangue, sem que atenuantes ou argumentos justificativos se interponham. Apolo encarna uma nova posição, mais tolerante, que é a dos olímpicos. Se o crime exige expiação, a punição tem de ser avaliada porque the assiste um direito próprio. A radicalização é, em termos gerais, o que afasta as duas concepções de justiça. Mas o caso particular da casa argiva é, no concreto, um novo factor de dissidência. Para Apolo todos os crimes merecem julgamento e eventual punição; enquanto as Erínias tratam com rigor máximo o derramamento do mesmo sangue, como aquele que liga mãe e filho, e toleram o assassínio de um marido pela mulher, porque o sangue vertido é diferente. É com propriedade que Apolo as acusa de distorcerem um verdadeiro sentido de justiça e de menosprezarem a instituição do casamento, que tem em Zeus e Hera o seu símbolo máximo. Esta menção do matrimónio tem um sentido fundamental na Oresteia, e representa para o deus de Delfos um sinal da primeira vitória sobre as Erínias na confrontação de argumentos. Neste primeiro suscitar de uma questão fundamental na ordem que rege o mundo, nada mais se avança do que na repartição dicotómica das forças activas. Os deuses estão divididos, as suas prerrogativas opõem-se em dimensões radicais, a distância a separá-los é máxima. Mas Apolo deixa em aberto uma solução, que transfere para as mãos de Atena e para a clarividência da cidade que a deusa patrocina. Aí a legalidade será avaliada e encontrada para o conflito uma saída que se adivinha pacificadora e lúcida. $\bigcirc$ que parecia encaminhar-se no sentido de um conflito cósmico vai afinal encontrar solução em terreno 
humano, numa feliz cooperação de deuses e homens por aceitação comum de um novo plano de justiça.

Com esta promessa o cenário muda, tempos passados sobre a partida de Orestes a caminho da sua odisseia de sofrimento sob a ameaça das Erínias. É já em Atenas que o vamos reencontrar, depois de redimido da mancha poluente, a envolver nos braços, em gesto de súplica, a estátua protectora da deusa de quem espera a redenção final. De novo as Erínias o seguem, repetindo o quadro de Delfos. Só que agora o sono não as controla, antes activas e tomadas de fúria, elas executam a sua dança mágica e incantatória em torno da presa. A situação de Orestes é climática, a prece que dirige à deusa Atena desesperada.

Atena aparece, vinda de longe, mas envolta na imagem poética de uma epifania. Por palavras, a própria deusa dá voz à leveza imaginativa da sua aparição (403-405): também os seus passos são infatigáveis, o seu andar tem a ligeireza do voo; em vez do carro, é a égide inchada pelos ventos o transporte alado da filha de Zeus. Mas à leveza, Atena junta também a tolerância. Ao tom irado que Apolo usara em Delfos para com as deusas detestadas das sombras, Atena substitui palavras brandas, não isentas de surpresa, mas sobretudo ditadas por uma natural imparcialidade. $\mathrm{Na}$ criatura humana que se enlaça na sua estátua, a deusa reconhece um suplicante; quanto às perseguidoras, Atena repete a surpresa da Pítia, não reconhecendo nelas afinidades nem com os deuses nem com os homens (408-4/2). A cada uma das partes, fugitivo e perseguidoras, a deusa dirige uma interrogação, sem distinções nem preferências, mas com a serenidade que caracteriza os que detêm capacidade para uma arbitragem justa. Por isso as deusas da Noite the reconhecem supremacia e the acatam o arbítrio. Uma primeira fase do processo se inicia com o registo da audição das duas partes: as Erínias declaram a sua identidade e as prerrogativas que a tradição lhes consagrou e que fazem de Orestes sua vítima sem direitos nem apelos. E, no entanto, uma primeira brecha se abre na autoridade até então irredutível das Erínias, que se sujeitam à investigação e à sentença ditada por Atena (433). Por sua vez a Orestes é dada voz para esboçar os seus argumentos de defesa: antes de mais, o suplicante valoriza a justificação necessária a uma intervenção junto da deusa; depois, narra os antecedentes justificativos do seu acto, que teve o patrocínio de Apolo para que um crime tremendo não ficasse sem retaliação. $E$ também $O$ arguido se dobra à autoridade suprema da deusa. 
Com este preâmbulo de um julgamento, a justiça conhece uma nova ordem. Não se trata já de executar, sem discussão, uma punição automática e extrema. Perante um árbitro de imparcialidade reconhecida e aceite, terá lugar um debate, onde os argumentos serão expostos e ponderados, onde a persuasão irá exprimir motivos e condicionantes, até que um voto final consagre uma decisão por todos acatada. Diante dos deuses e dos homens, Atena institui, na sua cidade, um tribunal. A nova ordem nem mesmo será competência exclusiva dos deuses, mas responsabilidade entre todos partilhada. Ao lado da autoridade olímpica, os cidadãos mais credenciados, vinculados pelo rigor de um juramento, irão manifestar também o seu juízo, homens e deuses ligados por um supremo intuito de justiça, que garante uma nova ordem, onde a piedade tempera o rigor e a necessidade pedagógica de punição. A hora é de profunda mudança no regime cósmico, que tende para um princípio de civilização até então desconhecido. E este contributo ao progresso universal tem por cenário Atenas, por árbitro supremo a sua deusa protectora e por entidades em litígio as autoridades do passado e a vontade inovadora dos olímpicos. $O$ canto que o coro entoa no intervalo que separa os depoimentos prévios do julgamento concreto (490-565) é um inventário superior de tudo o que está em causa neste momento paradigmático. As Erínias adivinham a instituição de um novo modelo legal, dentro do qual qualquer réu, mesmo se culpado de um crime máximo, pode ser absolvido; o seu alvo deixa de ser Orestes, para passar a ter um alcance colectivo ou mesmo universal. As deusas prevêem-lhe também os riscos: a tolerância é amiga do facilitismo e incentivadora de uma violência impune. Para contradizer este novo padrão de crime, sentem-se as Erínias credenciadas como garantes infalíveis da punição. Clara, ainda que impiedosa, a justiça taliónica desanima e tolhe o crime. É entre as duas balizas que o mundo se suspende: anarquia ou despotismo, o que pode melhor servir a ordem cósmica? Como conviverão os humanos, quando o Medo, arma poderosa da Justiça e sua medida profiláctica, ceder lugar a uma tolerância irresponsável?

É para responder a todas estas questões fundamentais que um primeiro julgamento tem lugar. Apolo chega, para intervir na defesa de Orestes (574-580), depois de ouvir a voz da acusação expressa pelas Erínias. $\bigcirc$ réu é submetido, pela acusação, a um interrogatório formal e directo, a que uma esticomitia confere a energia indispensável. São passados em revista os dados objectivos: Orestes matou a mãe a golpe de espada, para obedecer a ordens de Apolo, e para punir o duplo crime de Clitemnestra, o assassínio de um 
marido e de um pai. Logo aos depoimentos objectivos dá lugar a controvérsia: se as Erínias punem quem verte sangue do seu sangue, estará Orestes sujeito a esta penalização? $\bigcirc$ mesmo é dizer, serão mãe e filho sangue do mesmo sangue? Em tão estranha polémica, Apolo substitui o seu protegido na arguição. E o supremo argumento do deus adia a razão jurídica concreta e a resposta à questão levantada. À ordem judicial sobrepõe o deus um argumento superior (6|6-6|8): a Zeus cabe a autoridade máxima na execução da justiça, dentro de uma nova ordem hierárquica do universo. É a submissão aos desígnios de Zeus que ela pressagia. Depois Apolo considera a questão concreta a um nível definido: a prerrogativa máscula do herói tem prioridade sobre a traição de uma mulher, logo o crime de Argos resulta em vantagem para Agamémnon e em culpa para Clitemnestra. Está salvaguardada a necessidade de punição contra a mulher que matou o soberano e o marido. Falta avaliar o crime contra o pai. E o deus de Delfos vai satisfazer esta questão com a afirmação de um vínculo de hereditariedade sólido entre o progenitor masculino e o descendente; nessa ligação de progenitura, o papel da mãe é inactivo, como simples receptáculo de um germe, o que the confere uma posição lateral e passiva na procriação. A qualidade dos argumentos usados, bem como a tentativa de sedução de cada uma das partes na resolução final do júri têm sido lidas por muitos estudiosos da tragédia como uma caricatura ou paródia de uma verdadeira sessão de tribunal em Atenas. Em relação a Ésquilo, aceitar esta teoria seria pôr em causa toda a emoção obtida com a maternidade de Clitemnestra em relação a Ifigénia, no Agamémnon, ou o tremendo dilema do matricídio, nas Coéforas. Mas, apesar de todas as debilidades que se lhe possam apontar, e que são do foro humano, o tribunal é uma referência como sede de execução de uma justiça que, em última análise, ascende à lucidez inabalável de Zeus.

Um discurso de fundação do tribunal do Areópago, que lhe consagre para o futuro o ascendente e a legitimidade, é feito por Atena antes da votação decisiva. Com a sua alocução, a deusa define as bases de um novo conceito de justiça; aos cidadãos, ela há-de impor-se pelo Respeito e pelo Temor que previnam a violência e fomentem a ordem e a paz cívica. Nesta medida não há ruptura com a justiça anterior, que está subjacente à evolução que se prevê. Dos juízes, ela exigirá a exclusão da anarquia e do despotismo, em nome de um equilíbrio responsável e regulador. $\mathrm{A}$ ordem resultante é serena, mas determinada, e produz harmonia e felicidade. 
É sob esta nova filosofia que os votos caem na urna. Com o voto do juiz, Orestes atinge o empate e sai ilibado. A simples igualdade de opiniões é decisiva para resolver a tremenda dúvida que um conflito entre laços de sangue e obrigação de vingança coloca. A persuasão ganhou a sua primeira vitória sobre uma justiça cega e inflexível. Importa ainda conquistar as Erínias e canalizar a sua potência justiceira num sentido elevado de rigor. Num longo epirrema, Atena vai ganhando a adesão das deusas enfurecidas. Os seus argumentos são variados, dentro do mesmo espírito que ditou a fundação do tribunal do Areópago: um empate não significa humilhação, sobretudo quando o lado ganhador beneficia do patrocínio de Zeus. Às deusas Atena oferece acolhimento na sua cidade e um culto solene que exprima a veneração de que são merecedoras. Sem esmorecer perante a renitência das Erínias, a filha de Zeus insiste na legitimidade de uma nova justiça que não desmerece do rigor do passado, apenas comporta uma flexibilidade razoável e ponderada. Armada de uma persuasão inabalável e de uma tolerância sedutora, Atena vence. As Erínias cedem, seduzidas por uma tranquilidade que lhes dobra a fúria e as assimila como deusas benfazejas e protectoras. A Atenas prometem benefícios múltiplos: harmonia e fertilidade antes de mais, a salvaguarda das leis ancestrais, sem abdicar da punição dos crimes de sangue. Mas o que elas sobretudo pressagiam é uma ordem interna, que neutralize tensões, propicie um clima de paz e premeie com benesses aqueles que honram a justiça.

Para além das peças conservadas, é óbvio que a produção perdida de Ésquilo reproduzia com abundância episódios em que a intervenção divina em cena é inegável. Do papel que Atena desempenha como pacificadora das Erínias é por vezes aproximado o que competia a Afrodite como pacificadora das Danaides na trilogia respectiva. Parece certo que à deusa cabia um discurso, em que proclamava o poder universal da paixão (fr. 44 Radt). Pelo conteúdo parece também consensual que esta rhesis ocorresse perto do final da trilogia. Dirigida às Danaides, ela seria também um exercício bem sucedido de persuasão no sentido de as demover ao casamento, depois da reacção de fuga anómala que a perseguição dos Egípcios nelas acendeu. Numa dedução feliz, Winnington-Ingram ${ }^{28}$ remata com uma observação que seria também em parte aplicável às Erínias: 'Se este ponto de vista for correcto, a trilogia acaba como começou,

28 'The Danaid trilogy of Aeschylus', 144. 
com a posição das Danaides face ao casamento; mas uma mudança radical de atitude se operou, no sentido da sua conversão'.

\section{Possuídos pelos deuses}

São várias e célebres as cenas do teatro esquiliano centradas sobre uma personagem possuída pelos deuses. Caracterizam-se por uma emoção e sentimento de dor marcados, que têm uma expressão altamente dramática. A presença divina que corporizam vai-se tornando mais perceptível, num crescendo em que o enthousiasmos progride em simultâneo com um conjunto de sinais exteriores. Através de sons inarticulados, de gritos, de delírio, de corrida, de rodopio, os mortais atingidos pela penetração do espírito divino perdem a humanidade para se assumirem de certa forma como corporizações do além. Para além dos gestos, as palavras que pronunciam atingem todos os tons, do obscuro ou intraduzível ao claro e lúcido. A mensagem que thes compete transmitir vai-se tornando mais compreensível, exprimindo-se muitas vezes por uma espécie de sucessão de quadros impressionistas, onde os traços em destaque são falantes. Dos seus interlocutores se esperam reacções diversas: de uma surpresa ou incompreensão expectante, eles vão aderindo à verdade oculta das palavras, cuja revelação pode ser facultada por quem se encontra possuído ou por quem o observa e escuta. Faz sentido que a exaltação e o carácter de revelação ou de esclarecimento próprio destes episódios tenha uma relação directa com a natureza, que parece convencional, dos seus intervenientes. Os atingidos pelos deuses são jovens, espíritos mais frágeis e susceptíveis de emoção, talvez mesmo sobretudo mulheres. A sua relação com o deus que os perturba é variada, mas implica uma proximidade que se justifica pelo envolvimento amoroso ou por uma conivência entre o humano e o divino em qualquer momento relevante da vida do mortal. Do outro lado, aqueles que assistem ao enthousiasmos falam mais pela voz da idade, da experiência ou do saber, porque deles se espera uma atitude de interpretação e de compreensão. É indiscutível o profundo efeito cénico destes momentos, em que mais uma vez Ésquilo traz ao contacto da percepção humana as forças ocultas do universo. Mas, mais do que garantir espectáculo, estes episódios têm sempre uma pertinência evidente no desenrolar da aç̧ão. Algumas das suas funções são a um primeiro olhar sensíveis: a da extensão, para 
- plano do extracénico, da acção concreta, com a ruptura dos limites do visível para o que a fachada do cenário oculta; a supressão de barreiras temporais, que inserem os acontecimentos presentes numa linha de continuidade, que thes dá a lógica de um elo apenas numa cadeia ininterrupta de factos; um aprofundamento do imediatamente visível ou perceptível, através de uma interpretação mais reflectida do seu sentido essencial.

Duas figuras femininas corporizam no teatro conservado de Ésquilo esta experiência: lo, a princesa de Argos em fuga pelos confins da Cítia, no Prometeu, e Cassandra, a cativa troiana trazida por Agamémnon até ao portal do seu palácio em Argos, no Agamémnon. Porque ambas no exilio, perseguidas ou cativas, afastadas da segurança da casa ou da familia, elas são particularmente vulneráveis a um sofrimento acrescido a que o destino as votou. Da sua história passada faz parte a paixão de um deus que, seduzido pela sua beleza e atractivos femininos, as desejou: o próprio pai dos deuses, que exigiu sem tolerância ou piedade a rendição de lo ao seu desejo amoroso (Prometeu 589592, 649-65 I); e Apolo, a quem Cassandra prometeu cedência e a quem traiu (Agamémnon 1203-1212); iludido pela troiana, o deus puniu-a com uma dádiva: a dos dons proféticos, a que acrescentou uma irónica impotência, por nunca serem aceites ou entendidos os seus vaticínios. Vítimas da interferência divina, as duas jovens viram-se exiladas da pátria, ou porque o afastamento de casa se mostrou condição para a consumação dos planos divinos, como foi imposto à filha de Ínaco (Prometeu 652-672); ou porque todas as previsões com que, no caso de Cassandra, tentou salvar a pátria de uma guerra feroz, não alcançaram, pela indiferença dos que as ouviam, o efeito desejado.

Ésquilo opta por duas estratégias diferentes, mas igualmente poderosas, para pôr diante do público cada uma destas duas personagens. A vinda de lo caracteriza-se pela agitação e pelo movimento de fuga, que estimula uma perseguida, tanto mais vibrante se contrastada com a imobilidade do prisioneiro, Prometeu, seu igual como vítima da ira de Zeus. A sua chegada é inesperada e por isso tanto mais espectacular (562-565). A desorientação que manifesta perante um lugar que não conhece é vibrantemente traduzida por uma série de interrogações. $O$ exilio e as penas da perseguição e do perigo são nela corporizados com aparato. A entrada de Cassandra é discreta, mas terrivelmente enigmática. Sobre o carro que traz um Agamémnon vitorioso em Tróia de volta a casa, vem também uma mulher, princesa envolta em silêncio e mistério durante toda uma longa cena em que o Atrida é acolhido por 
Clitemnestra e entra no palácio (783-1034). Atento ao diálogo entre o casal régio, o espectador não deixa de manter um olhar surpreendido sobre a jovem, aguardando o momento de uma justificação da sua presença. Finalmente ele chega, tardio, com a recomendação de Agamémnon à esposa, para que a acolha em casa, com bondade, como sua cativa (950-955). Mas um compasso de espera adia ainda o momento em que um foco se vai concentrar sobre a jovem; só depois de entrar no palácio com o rei enquanto o coro renova crescentes apreensões, Clitemnestra volta ao encontro da Troiana. Pela primeira vez Ihe ouvimos o nome, Cassandra, mas o convite da rainha fica sem resposta: nem um gesto nem uma palavra (vide Silêncio). Logo alguma estranha agitação, de 'animal recentemente capturado' (1063-1067), parece denunciar a indocilidade louca da cativa para desespero e raiva de Clitemnestra. Só, depois de vencida pela barreira do silêncio, reentrar no palácio, a filha de Príamo actua com toda a exuberância do enthousiasmos.

Depois da entrada, mais ou menos longa, ocorre a crise e essa reveste um grande aparato de expressão corporal. $\bigcirc$ sentimento que tudo controla é o temor e a incapacidade de opor resistência a alguma coisa que se apodera do corpo e do espírito da sua vítima; lo confessa o seu terror (Prometeu 568, 580), foge espavorida de um perseguidor $(572-574,576)$, grita com espanto a sua loucura (581).Vem-lhe aos lábios o nome de um deus, em quem se identifica a causa do seu mal (578), e aos seus olhos imagens de um perigo que só a ela é patente, o do moscardo, que a impele no seu louco divagar (566). De todo este comportamento confuso um traço exterior é pelo menos concreto: a donzela exibe um par de cornos (588), metamorfose que se operou no passado e se tornou insígnia do seu destino (673-682) de animal errante. No conjunto, ela é a encarnação de uma humanidade primária: animalesca de aspecto, enlouquecida e visivelmente incapaz de carregar o seu destino. Cassandra vive em Argos uma crise semelhante. Depois de uma longa imobilidade e silêncio, a mudança é também repentina e surpreendente. Os gritos enchem a cena num tom lúgubre e doloroso (Agamémnon 1073-1074), enquanto repete o nome do deus que a agita (1073-1076, 1080-108|, 10851086). Fareja a verdade e encontra a pista do sangue ( 1093-1094) para além das evidências. Tomada de delírio, verbaliza, em repetições insistentes, a mensagem do deus que a possui (| |40-| | 45, | | 50-| | 55).

Dentro e fora da cena, a atenção de todos está presa. Mas o desenvolvimento da situação é, em cada situação, diverso. $O$ mal que aflige lo 
e lhe justifica o enthousiasmos é inteiramente pessoal, é o seu destino que está em causa, e a compreensão de um sofrimento que a atormenta. Porque vítima de prepotência divina, a sua existência pode comparar-se à de Prometeu e trazer à figura central da peça uma solidariedade que advém da semelhança de situações e confluência de experiências. A lo falta a compreensão do seu destino e a capacidade de prever o desfecho da errância que a condiciona. É em busca de quem a possa elucidar que ela chega e consulta Prometeu como o detentor de uma lucidez que ela não possui (593-6/2). Facilmente dele obtém a satisfação do seu pedido não sem que, tal como Cassandra, o prisioneiro do Cáucaso the não confesse a inutilidade da previsão (624). Para que o futuro da princesa argiva ganhe nexo como o prolongamento de um passado, basta agilizar a intervenção do coro de Oceânides, tal como o público uma testemunha desconhecedora de uma situação sobre a qual deve ser informada. Assim, depois de uma rhesis em que lo relata, em tom descritivo e sereno, os seus dias de outrora, é chegada a revelação que compete a Prometeu. Também esta é longa, minuciosa de pormenores. No entanto, a quebrar a extensão informativa desta previsão, lo retoma, pouco a pouco, os sinais do delírio (742). Embora desta vez mais racional na sua expressão, porque controlado pelo esclarecimento, não deixa de ser, mesmo assim, exaltado. A jovem debate-se entre o suicídio ou a aceitação do prolongamento do seu sofrer. Mas o mal de lo tem esperança de salvação, porque algo parece estar para mudar na ordem divina (755-768), mudança a que a descendência da princesa não será alheia (769-876).

Sem que lo faça uma opção, o seu destino está traçado e a obrigação de o levar ao fim é incontornável. Já de novo o delírio a possui (877-886): um grito seguido de um espasmo, a picada do moscardo que a enfurece; no seu interior as vísceras fremem, numa adesão profunda de todo o seu ser. Com as palavras que se confundem, lo terminou a sua presença em cena, porque já a fuga a lança no cumprimento final da sua rota.

Para além do movimento físico, o enthousiasmos de Cassandra é particularmente significativo pelas palavras que ela pronuncia (| |32-| | 35). A jovem é uma profetisa, por isso ligada a uma percepção superior dos factos que, através dela, Apolo revela aos homens. E a mensagem que a electriza tem um alcance muito mais amplo do que o seu destino pessoal. De resto, essa é uma questão que flui no seu espírito no final da crise; porque antes o que se impõe é a sorte da casa dos Atridas, numa longa retrospectiva de gerações a 
que se acrescentarão muito em breve novos episódios. É nessa corrente que a própria sorte de Cassandra se insere, o que torna esta mulher estranha à casa, desconhecida de todos, bárbara de origem, um elo coerente na cadeia que constitui a vida da casa real de Argos. Do ponto de vista dramático, as profecias de Cassandra são um elemento de coerência, porque articulam e justificam todos os dados da tragédia num momento central, acrescentando à culpa de Agamémnon factores de hereditariedade e de destino que dão à punição iminente uma razoabilidade mais completa. Esta concentração de ideias tem, na boca da profetisa, uma espectacularidade formidável. $\bigcirc$ tom do seu discurso alterna, do lírico, exaltado e enigmático, para o narrativo, sereno e transparente. Em consonância com esta variação, o coro de velhos que é na cena a testemunha e intérprete das visões, decerto como espelho do próprio público, alterna nas reacções: ora se manifesta confuso e incrédulo, ora esclarecido e apavorado. Num fluxo de enigmas e de rasgos de evidência, o enthousiasmos prossegue sem quebras a caminho de uma revelação total. Mais uma vez a regra do páthei máthos tem a sua aplicação específica.

Cassandra, entregue ao delírio, carece de coerência. Rodeada pelo coro, não é no entanto a ele que se dirige porque alheada do ambiente imediato que a cerca; as palavras que lhe brotam, sem ordem, da boca são, de uma visão íntima, o explodir exterior quase involuntário e sem um destinatário directo. $\bigcirc$ que parece ser, nas palavras inicialmente balbuciadas por Cassandra, uma simples interrogação convencional sobre o seu destino e desenraizamento num lugar desconhecido, numa atitude paralela com a de lo (1080- | 087), abre-se de forma inesperada sobre 'a casa dos Atridas' ( 1088 ) com a informação prestada pelos velhos. Talvez mesmo a personagem descesse desde logo do carro e, ao caminhar em direcção ao palácio, pressentisse nesse contacto todo o horror que ele escondia. Como se reagisse particularmente à palavra 'Atridas', alusiva a toda uma familia, Cassandra tem a sua primeira visão; esta exprime-se numa tela de realismo quase grotesco, que poderia legendar-se de ' $\mathrm{O}$ crime' - o rubro disperso do sangue, cabeças cortadas, um matadouro humano (I090-1092). Seguida, logo depois, de um segundo quadro, 'O banquete', em que as cores brutais não desmerecem do precedente (1095-1097): crianças amedrontadas sob a ameaça da lâmina e carnes assadas de filhos devoradas por um pai. Perante alguma indiferença dos seus ouvintes directos, que no entanto reconhecem nas palavras de Cassandra imagens familiares, ela avança para o presente. Interrogativa, hesitante, um outro motivo ganha forma a seus olhos, 'O 
banho de morte' ( | |07-| | I I): a mão feminina da esposa que prepara $\circ$ banho do marido, e logo dois braços que ferem, em movimentos cúmplices e com ferocidade gémea. Num frenesim maior, Cassandra vê a tela seguinte, ' $O$ sacrifício' ( | | |4-| | 29): como uma rede que enleia a presa, a sacrificadora captura o homem indefeso e, num grito ritual, saúda o golpe com que, num altar de opróbrio, sacrifica a sua vítima. A sombra cai sobre os olhos do animal abatido, em ondas de um sangue amarelo de morte; possante como um touro de pontas negras, a fera desaba dobrada ao poder traiçoeiro da fêmea, que repete um golpe incansável. A emoção e a perplexidade crescem em volta, naqueles que ainda não compreendem por completo a cena, mas nela percebem já as cores da morte. Nova tela se alinha, 'O último suspiro de Tróia' ( I | 36- | 177), envolta numa exaltação contagiante; é o seu próprio destino que Cassandra exprime com emoção imensa e o coro, apanhado por uma nota de dor profunda que o não deixa indiferente, transmite num canto toda a perplexidade que o aprisiona. Uma sorte sem paralelo se desenha como um golpe brutal sobre a fronte pura e jovem de uma outra vítima, a filha de Príamo, a última réplica de todos os filhos chacinados, depois da descendência de Tiestes, de lfigénia, das crianças troianas. Nas suas contendas familiares como nas guerras que desencadeiam os Atridas são sangrentos e genocidas, indiferentes ao direito sagrado da vida e da continuidade da espécie humana. Chacinam sem piedade nem escrúpulo, conspurcam a ordem cósmica universal. De repente o crime transborda dos limites de uma casa para as fronteiras ilimitadas do cosmos. Tróia à distância paga também a insolência de Páris e a sua última pedra rola com o golpe que se abate sobre a derradeira descendente da casa real. Enfim, a sorte do vencedor e do vencido confluem para um desfecho semelhante.

Como se tivesse entretanto tomado consciência da presença do coro, Cassandra procura comunicar com ele, deixando o tom enigmático para traduzir com precisão a mesma mensagem. As profecias tornam-se, como o coro bem o reconhece (1|62-1163), evidentes e cada nova imagem se encadeia logicamente com a anterior ( I I73). Para que toda a mensagem seja clara, a vidente, em contacto mais humanizado e mais próximo com os velhos argivos, repete o sentido global do seu relato, desta vez 'sem véus' ( | |78, | | 83) que o obscureçam, o que quer dizer na precisão objectiva dos trímetros narrativos. Cada pegada de um caminho de maldição a que as Erínias vingadoras do sangue votaram aquela casa é recapitulada, desde o seu passado inicial e sujeito a confirmação pelo conhecimento seguro dos velhos. Mas a quebra na 
vibração profética é apenas uma suspensão que tornará mais intenso um delírio que já regressa. Cassandra rodopia, geme e clama, outra vez possuída, para retomar o percurso de uma galeria de quadros de sangue (1215-1238). Somente a linguagem com que os revê é mais nítida, apoiada numa tonalidade narrativa e não lírica. $O$ catálogo dos crimes essenciais é de novo enumerado em tons crus e ofensivos: o sacrifício de crianças, sentadas à porta do palácio como se espoliadas da vida e do que é seu, quais sombras da morte, que estendem mãos carregadas das próprias vísceras (1217-1222); a vingança que se aproxima em toda a sua brutalidade, executada por uma fera cobarde, que se resguarda na protecção da casa, e se oculta até ferir de morte o senhor do palácio no regresso (1223-1226); também figura uma Clitemnestra expectante, revestida da imagem de um monstro assassino, tomada de uma fúria ressentida, pronta a saltar com a agilidade traiçoeira de uma fêmea sobre o macho indefeso; com a mesma violência assassina, a soberana de Argos inflecte sobre a própria troiana, que numa só estocada paga a dívida em aberto para com um Apolo apaixonado que traiu e o adultério ofensivo do Atrida (|258-|263). Num gesto final de desespero e de impotência, Cassandra quebra as insígnias de profetisa, a vara e as coroas, que são a evidência do seu poder divinatório e o lema de um destino infeliz (1264- |267).

O coro e o público seguem atentamente esta interpretação que se revela sem obscuridades, enquanto Cassandra projecta uma outra faceta da sua natureza: para além de visionária e de medium mais ou menos inconsciente de uma mensagem divina, ela comporta também esta outra face, igualmente responsável por um enorme sofrimento, que é a sua capacidade de entender e de revelar o sentido oculto dos sinais que recebe. $\bigcirc$ futuro mais longínquo é também pela primeira vez enunciado. Após os crimes que se executam para além da porta cerrada do palácio, um outro dia vai trazer um novo vingador; um filho vai chegar incumbido de uma estranha missão: a de matar a mãe para vingar o pai. Essa será a última pedra na construção de um edifício de infelicidade, a que cada geração de uma familia deu o seu contributo.

É exactamente este anunciado vingador a personagem que irá sofrer um delírio causado pelos deuses na hora precisa em que se queda dividido perante o seu acto: satisfeito do dever cumprido, mas atingido por uma culpa insustentável. Orestes é a encarnação de uma vitória que, mesmo se justa, traz por insígnia uma mancha poluente (Coéforas 1010-10|7). Com uma emoção crescente, que não atinge no entanto a exuberância a que a sensibilidade 
feminina pode ascender, Orestes é a imagem do remorso. E este é, na reprodução que dele dá Ésquilo, não a reacção íntima de uma alma culpada, que nasce de dentro e é uma atitude profundamente humana, mas a penetração, do exterior, de uma ira divina, que revolve os corações e exige uma cobrança em igual medida. Ainda o matador de Clitemnestra goteja o sangue materno e já os primeiros sintomas de uma crise nos são por ele revelados (1022-1033). O terror desvia-o da linha de corrida; sem controle sobre si próprio, capaz de brados sonoros, sem no entanto que a lucidez se esvaia. Por isso o próprio é capaz de um diagnóstico dos seus actos e culpas, dos estímulos que o levaram a agir, das razões implicadas. Mas o conhecimento do futuro está-lhe vedado, porque de um simples mortal se trata. Todavia, no momento de dirigir para Delfos os seus passos, à procura da clarividência superior que lhe falta, Orestes tem a sua visão terrífica. Na sua frente, apenas visíveis aos olhos da sua alma, mas ocultas a todos os presentes, estão as Erínias, as fibras do seu remorso: mulheres vestidas de negro, envoltas em serpentes sem conta, a gotejarem lágrimas de sangue, este é o retrato divino de um remorso que dá pelo nome de Erínias, as deusas da cobrança. Tomado de um enthousiasmos, perante um coro incrédulo e confundido, Orestes move-se ( 1050 ), foge, revolve-se, mas entende: é chegada a hora da vingança materna e estas imagens não são fantasmas vãos, mas tão só as procuradoras da sua vítima (1064). Chegou para Orestes o tempo da errância, tal como para lo, em busca de um destino desconhecido que ansiosamente procura conhecer. Estimulado pelo aguilhão do remorso que o morde sem tréguas, como à princesa de Argos o moscardo, Orestes põe-se em fuga, numa corrida desvairada, para encontrar em Delfos, através do mais seguro dos oráculos, uma firme mesmo se distante promessa de justiça e de redenção.

\section{Fantasmas}

A presença de fantasmas na cena de Ésquilo, visível ou apenas perceptível mas sempre actuante, ocorre em momentos de grande tensão e sofrimento. Acontece portanto em contextos de exaltação com frequência agravados por visões ou manifestações do além, e é, em si mesma, factor de enorme emotividade. De uma forma geral exprime um contacto privilegiado e excepcional entre dois mundos, o dos vivos e o dos mortos, estabelecendo entre eles uma relação próxima da que existe entre mortais e divindades. Da homenagem que 
se presta aos parentes mortos, os vivos esperam preservação contra os males que os ameaçam e o patrocínio para a superação da crise. A sua esperança alimenta-se de uma proximidade que garante entre parentes um diálogo mais pessoal e mais íntimo e que permite esperar uma intervenção privada e directa sobre interesses concretos. Porque em geral se trata de fantasmas de soberanos, $\mathrm{O}$ alcance da graça que se espera pode ser mais do que pessoal, dirigido também para o benefício de todo um povo. Em qualquer dos casos, implica uma intimidade que se traduz nas relações dos agentes que veiculam a prece; eles terão de ter com o morto um elo de consanguinidade ou pelo menos um vínculo de amizade e de convivência consistente. Este convívio exige porém mãos limpas, ausência total de derramamento de sangue, ou a aparência da normalidade exterior do ritual não impedirá os seus efeitos nefastos.

É desde logo em Persas que encontramos exemplo deste tipo de cena e de personagem. A crise em Susa é perceptível; tem um carácter colectivo e resulta dos riscos assumidos por um monarca leviano dominado pela ambição de conquista. Ao silêncio tenebroso que caiu sobre o destino dos guerreiros em campanha vieram juntar-se outros sinais assustadores através de sonhos e presságios. $\bigcirc$ momento é de angústia profunda, corporizada nos velhos conselheiros fiéis ao rei e na soberana viúva de Dario. Impossibilitados de qualquer outra actuação, os representantes do povo persa refugiam-se na prece. É a Atossa, mulher e rainha, que compete conduzir o cerimonial, dentro de um código convencional rígido de que os velhos enunciam o protocolo (215-223): são os deuses os primeiros destinatários da súplica, que deve ser antes de mais apotropaica, capaz de afastar uma sensível ameaça de sofrimento; depois do afastamento dos males, imploram-se as benesses para todos os aflitos, da casa e da pátria. E em resposta à aparição de Dario que Atossa vira em sonhos testemunhar a derrota de Xerxes (197-199), convém voltar também para os ínferos a intenção da prece. Que se contemplem a Terra e os mortos, mas em particular Dario, o esposo de Atossa; quando dirigida ao fantasma do rei morto, a prece ganha um tom intimista e pessoal (220-222): as palavras devem vir do fundo da alma, numa súplica de protecção e bem estar para a esposa e o filho. Este é apenas, em Persas, um primeiro ritual de resposta a simples temores ainda não confirmados, que se tornará num cerimonial de enorme envolvimento depois que a derrota foi narrada pelo arauto.

Coéforas reproduz, nas suas grandes linhas, uma situação equivalente. Também uma crise profunda está latente em Argos. Sete anos passaram sobre 
- assassínio de Agamémnon, sete longos anos de permanência no poder dos usurpadores do trono, Clitemnestra e Egisto. A cidade sofre sob o domínio pesado e injusto do par régio, como sofrem também os filhos de Agamémnon espoliados dos seus direitos e indefesos. Em aberto continua a dívida de um crime de traição e de violência, que vitimou o conquistador de Tróia, a aguardar o cumprimento da regra inevitável da retribuição (55-74). Orestes aparece, ainda incógnito, no início da peça, orientado por Apolo na sua missão de vingador, jovem frágil sobre quem pesa a terrível incumbência de trazer à casa a que pertence novo derramamento de sangue. A crise é tremenda, na família dos Atridas como entre a comunidade argiva. Por isso Orestes se refugia na prece como um recurso indispensável à superação da angústia (I-2): junto ao túmulo do pai, as suas evocações vão espontaneamente para Hermes senhor dos infernos e para o morto, para que o auxiliem na execução redentora de um acto que uma violência já consumada exige. Por fim é Zeus olímpico que cataliza as atenções do jovem, porque a sua prece é sobretudo um anseio pela consumação da vingança. São portanto ditadas pela justiça estas súplicas, que aproximam da sombra de um pai oculto no seu túmulo um filho e vingador, numa conivência legítima e necessária.

Mas porque a hora da retribuição chegou, a vontade dos deuses pôs diante dos olhos de Orestes, no mesmo tempo e local, os seus aliados naturais, o coro de servas e Electra, também elas motivadas pela necessidade da prece. Os objectivos das mulheres são todavia contraditórios, porque o ritual a que se entregam é ambíguo. As primeiras palavras deixam claro que é por ordem de outrem que executam o ritual (22-3I), não sem que o seu empenhamento e dor deixem de ser autênticos. Foi, como em Persas, o sinal da crise iminente que desencadeou a necessidade do rito (32-42): um sonho assustador anunciou, nos quartos femininos, a ira dos mortos e a urgência de vingança sobre os assassinos. Foi também a rainha a receber 0 alerta e a preparar $\circ$ ritual. Mas a crise agora tem contornos estranhos, porque em Clitemnestra coincide a esposa, a executante da homenagem e a matadora; a ameaça a pairar sobre Argos não vem de fora, é intrínseca e perturbadora do equilibrio natural do oikos. Porque é anti natura a situação, o cerimonial fúnebre torna-se impróprio, a sua convenção esbarra com a legitimidade dos factos; é ao mesmo tempo uma homenagem e um ultraje (43), encomendado ao coro de servas por uma mulher ímpia. Produz-se um paradoxo entre aparência e realidade: porque cativas no palácio, as mulheres têm de obedecer e executar um rito 
exteriormente correcto; mas sob os véus, no segredo da alma, o seu sentir é contrário, sedento não de pacificação mas de vingança.

Acompanha-as, integrada no cortejo, Electra e de repente o paradoxo torna-se mais visível e objecto de reflexão. A grande questão da peça é já neste momento colocada, como o dilema que resulta do significado de um acto que é ao mesmo tempo justo e correcto, mas também sacrílego e reprovável. Orestes, no kommos que se segue, vai dar a este conflito uma expressão mais alargada e dramática, quando se progride de um ritual que aspira por vingança para a execução da própria vingança. Neste momento que será de encontro e de colaboração dos dois filhos da vítima, a jovem princesa, como porta-voz natural de apelos e preces, interroga-se (84-99): que palavras usar na súplica quando as convencionais são impossíveis? Intolerável vincar os laços de familia que ligam marido e mulher; se se proteger apenas por trás de fórmulas consagradas, as benesses pedidas - a digna recompensa das oferendas trazidas em homenagem - ganham um duplo sentido, não o que serve a quem as invoca como apotropaicas, mas o que convém a quem anseia por vingança; talvez o silêncio possa transformar o ritual em simples gestos desligados dos votos habituais, pelo que não deixará de ser um rito distorcido e reprovável. A hesitação de Electra representa uma insegurança própria do carácter juvenil e imaturo da filha de Agamémnon, que se questiona sobre o rigor das práticas e sobretudo das palavras, com a consciência do efeito ominoso que delas advém. Mas valoriza o que é, neste quadro ritual, uma excepção: a quebra da normalidade de um rito, que se torna sacrilego e perigoso nos resultados. Ao mesmo tempo, toda a cena é o resolver de uma hesitação pela clarificação de uma regra. Todas as dúvidas juvenis de Electra são eliminadas pelo coro com a citação da regra da retribuição. Também desta forma o sentido do grande kommos que se segue tem já aqui uma expressão antecipada.

A reprodução do cerimonial em cena, de acordo com as regras protocolares, é um processo eficaz do ponto de vista cénico, como dramático; produz o clima hierático que convém ao carácter sacro e solene da tragédia, e colabora com a acção ao trazer ao universo do sofrimento humano uma abertura para um diálogo superior com os deuses e os mortos. Nos gestos e nas palavras é-lhe exigido o rigor, que traduz um respeito escrupuloso pelos destinatários a quem se dirige. Este é portanto um tipo de diálogo onde vários elementos teatrais se combinam: as atitudes e os movimentos obedecem a um código estrito, como também as palavras seguem um padrão rígido e um tom capaz de 
garantir uma comunicação que a distância entre a vida e morte dificulta. É preciso garantir que elas atinjam o mundo das trevas e encontram eco nas almas dos defuntos; o resultado é por vezes apenas expresso por trás de um silêncio, que no entanto deixa perceptível a adesão das forças ocultas; em alguns casos também suscita a aparição do morto e a vinda a cena de uma presença do além.

Atossa enumera as oferendas apaziguadoras que são devidas ao morto (609-6 18): o leite, o mel, a água, o vinho, o azeite e as coroas de flores, todas elas tocadas pela perfeição e pela pureza. $\bigcirc$ parentesco entre o morto e os ofertantes recomenda também um outro tipo de dádivas mais pessoais, as que são parte da natureza física que a todos une. $O$ anel de cabelo que Electra encontra sobre o túmulo do pai (Coéforas 6-7, I68) tem um significado claro: só alguém ligado a Agamémnon pelo sangue o poderia lá ter depositado e este raciocínio conduz a Orestes, porque nenhum dos outros parentes com as mãos sujas do crime o ousaria (170-178). Enquanto a terra engole as libações derramadas com piedade, é o momento de erguer as preces e os apelos (Persas 619-622, Coéforas 129-130). Esta função tem em Coéforas uma tal importância, pela sua espectacularidade e sentido, que as suas executantes dão o nome à peça.

São os deuses da morte os seus primeiros destinatários: a Terra, Hermes e Plutão (Persas 628-629, Coéforas 124-128); depois os mortos a quem se evoca em tom insistente e audível. Os votos expressos serão de apelo e de execração, irmanado o defunto e os vivos em correntes de proteç̧ão para os amigos e de ódio e punição para os inimigos (Coéforas 109-|21, |30-|48). Para além das intenções da prece, a sua eficácia exige vibração de atitude e de tonalidade. A proximidade do túmulo constitui condição necessária a um contacto efectivo (Persas 647-648, Coéforas 4-5, 334-335); o tom sonoro e lúgubre das preces, permeado de lágrimas e de lamentos, reproduz o ritmo de um treno fúnebre (Persas 633-637, Coéforas 150-157); por fim o rito sela-se com novas libações (Coéforas 149), que, ao sumirem-se no solo, garantem a consumação de um contacto entre dois mundos (Coéforas 164).

Idênticas na execução do ritual, as duas grandes cenas de evocação de mortos subjacentes à nossa análise têm objectivos diferentes, em função de contextos dramáticos precisos, e um desfecho em consonância com esses mesmos propósitos.

Apesar de já ter havido em Persas (215-230) a menção de preces dirigidas a Dario, que Atossa se compromete a executar dentro do palácio, nada entretanto sugere a ideia de uma aparição do próprio fantasma. Sem 
ter havido uma sugestão preparatória, a epifania, que é um momento climático quanto à interpretação temática como ao exotismo cénico, ganha ainda a força do inesperado e do insólito. Em Persas é ao coro que compete assumir por inteiro a evocação, enquanto a rainha em silêncio procede às libações (633-680). O empenhamento de todos é consensual e máximo, porque a todos move o mesmo desejo: o de trazer de volta à terra o fantasma de Dario, o rei protector que garantiu à Pérsia um passado de prosperidade, para que valha ao seu povo numa hora de angústia colectiva. Da sociedade persa, o velho rei conquistou a veneração, pela prudência com que sempre agiu e pela segurança que garantiu aos Persas, conduzindo o reino a uma prosperidade que mais parecia obra de um talento divino. São portanto os súbditos que apelam à protecção do seu monarca, num canto de onde a execração está ausente. $\bigcirc$ que se quer ouvir é o conselho e a previsão, como a garantia de que para o império do oriente haverá ainda um futuro. Mas é muito o que está em causa e por isso o apelo é envolvente e activo. Cheios de interrogativas e insistentes na ideia de 'ouvir e fazer-se ouvir', os brados do coro concretizam o esforço necessário para ultrapassar todo o espaço que os afasta de Dario. Multiplicam-se apelos de sofrimento e de expectativa, pelo desespero reinante a que só Dario pode vir trazer algum refrigério. E já em imaginação, o coro antevê a aparição do rei em plena majestade divina (658-662): sobre o túmulo, ele há-de erguer-se na solenidade da sandália cor de açafrão, enquanto na cabeça lhe brilha a tiara, insígnia da realeza.

A expectativa do coro e da rainha não é frustrada, porque o fantasma de Dario aí está, tocado pela prece dos seus, agradado com a oferta das libações, acessível àqueles que the são próximos, pela geração, pela partilha de preocupações, ou por elos de familia. $\bigcirc$ ritual resultou num êxito. Pela boca desta estranha personagem, o poeta justifica o próprio carácter excepcional da cena (688-692): só o ascendente particular de Dario e a proximidade do divino puderam obter dos deuses infernais a quebra de uma lei absoluta que faz da descida ao Hades um caminho sem retorno. Avaras dos seus súbditos, essas divindades são igualmente avaras do tempo, pelo que as raras ausências dos defuntos não podem exceder um tempo escasso.

É difícil o contacto entre o morto e os vivos, mau grado as confluências que os unem. A distância que o separa da vida dá à sua leitura dos factos um peso extraordinário, mas enfraquece os laços que o ligam às personagens que 
representam o mundo dos vivos. Diante do resplendor do fantasma, os velhos temem, ao respeito de outrora junta-se o pavor do além, e ficam-se incapazes de trocar um olhar ou uma palavra com a visão por que tanto ansiavam. É então Atossa, no privilégio de consorte real que detinha, quem Dario designa para consumar, com a sua inconsistência física, o diálogo necessário. $\bigcirc$ fantasma tem uma atitude fria e distante, como é próprio da sua condição impessoal. Como bem nota Michelini ${ }^{29}$, à falta de efeitos especiais para traduzir em cena a presença do sobrenatural, é da 'sua personalidade fantasmagórica que depende a impressão causada'. A alma de Dario não é também omnisciente; são-lhe desconhecidos os últimos acontecimentos que afectaram a segurança persa depois da derrota de Salamina. Sobre eles são os mortais mais capazes de uma informação. Mas nem por isso o seu estatuto especial de fantasma de um soberano sai afectado. Dario é de facto uma voz autorizada para interpretar os acontecimentos, porque conhece as regras que presidem à existência; esta é a credencial de um rei bem sucedido em vida, que se mantém um traço saudoso para o povo que dele se viu privado. Em Xerxes reconhece o rei impetuoso e imprudente, que foi ao extremo da ousadia ao consumar um projecto excessivo através de um sacrilégio que ousou com a subjugação do mar. Pelos seus erros, Xerxes precipitou a realização dos oráculos que os deuses já antes tinham feito ouvir (739-752). Dario pode então esclarecer e sistematizar o sentido geral da acção. A desgraça caiu sobre Susa pelo exercício conjunto da vontade dos deuses e dos homens; oráculos divinos e erros humanos uniformizaram-se para pôr em marcha a máquina do destino. Do lado dos mortais, Xerxes tem de assumir por inteiro a culpa; falta de visão, imprudência e a precipitação da juventude colaboraram na execução de um projecto onde a impiedade, antes de mais, e a desmesura prenunciavam um mau fim. Mais do que a conquista de um outro território, a campanha contra a Grécia definiu-se como um ataque contra o poder divino. Da análise objectiva que Dario faz sobre as responsabilidades do actual monarca está ausente qualquer tipo de comiseração ou de tolerância que a relação paternal pode justificar. As relações estritamente humanas esbatem-se com a ruptura causada pela morte.

Na sua ânsia imponderada de aventura, Xerxes pôs em risco um império que levou gerações a conquistar. Dario pode facilmente fazer um excurso pelo passado que o precedeu, mas de que ele é também parte integrante (759-78I).

29 Tradition and dramatic form in the Persians of Aeschylus (Leiden 1982) 143. 
E com olhos de profeta, passa a abarcar o futuro e a prever novas derrotas, até ao remate final do conflito. Para os sacrilégios cometidos em terra grega, com a destruição de templos e de estátuas de deuses, os Persas garantiram ainda um último castigo em Plateias, onde a divindade irá saldar as dívidas em aberto (800828). Dario faz então, com as credenciais que lhe assistem, a doutrinação sobre a grande moral deste episódio bélico: dike exprime-se por um inabalável equilibrio entre os direitos superiores dos deuses e a condição humana. Como supremo agente dessa mesma justiça, Zeus denuncia o orgulho e castiga-o na medida adequada. De novo, passando da avaliação geral à pessoa régia, Dario centra-se em Xerxes: porque imprudente na sua ousadia de jovem, terá de receber da experiência dos velhos conselheiros uma lição de moderação; e da rainha, os trajos adequados à assumpção da sua qualidade de rei. O futuro imediato é de crise e de luto, mas a salvação de um império está, apesar de tudo, assegurada.

É tempo de regressar às trevas, o reino onde as alegrias da vida não existem. Mesmo se castigado por algumas dores, o prazer da existência não tem, no Hades, rival ${ }^{30}$. Para os Persas, como para os espectadores de Ésquilo, a aparição do fantasma trouxe uma amplitude insuspeitada aos acontecimentos: num plano horizontal, ela abarcou o processo diacrónico da existência de um povo, nos seus contrastes de prosperidade e de retrocesso de acordo com a atitude governativa do soberano. Pela capacidade, como pela idade, Dario e Xerxes constituem uma oposição clara de actuação e de resultados. Mas o episódio da campanha grega tem também uma leitura vertical, numa perspectiva da universalidade do cosmos, onde a harmonia resulta da observância das regras que regulam o convívio entre a grandeza divina e a efemeridade dos mortais.

Depois de o destino ter reunido os dois filhos de Agamémnon, Orestes e Electra, é chegado para os herdeiros do trono de Argos e para o seu povo a hora da vingança. Várias forças se conjugam para a impulsionar: a ordem de Apolo, que é inflexível e comporta sanções se não cumprida; os ressentimentos dos filhos de Agamémnon, espoliados dos seus direitos e da herança paterna; o povo de Argos subjugado aos usurpadores e ferido pela memória poluente do crime. Deuses e homens reúnem-se numa vontade unânime. Mas importa mobilizar uma outra colaboração indispensável, a do morto, o vencedor de Tróia humilhado na sua honra por uma mulher, traiçoeira e adúltera.

30 Esta é uma filosofia coincidente com a expressa pelo fantasma de Aquiles em Odisseia II. 489-490. 
Em torno do túmulo do rei morto vibra um kommos, em que um coro de servas, ligadas ao defunto apenas pela ânsia de justiça e pelo repúdio pelo sangue criminosamente derramado, mas empenhadas no cumprimento de uma norma sagrada, 'quem agiu tem de sofrer' (Coéforas 313), se unem num canto aos dois filhos da vítima. Todos os agentes da vingança até aqui dispersos se encontram enfim unidos. $\bigcirc$ tom geral é exaltado, num crescendo progressivo. As vozes alternam, num ritmo permanente: Orestes e Electra, cada um por sua vez, dirigem ao pai um apelo inflamado, enquanto o coro a cada pausa os incentiva a não esmorecerem numa decisão que está a ser, a nossos olhos, consolidada. É evidente que o diálogo directo com Agamémnon parece vedado ao coro, porque restrito àqueles que lhe são próximos por elos de familia; as servas apenas dialogam com os príncipes argivos. Mas o empenho é semelhante e tende a mobilizar a determinação dos jovens vingadores, no plano dos vivos, e a conivência do defunto.

Repetidas, como antes junto de Electra (123), as regras da justiça cujo cumprimento importa respeitar (306-3|4), o que compete ao coro na qualidade de voz da experiência e da razão, dá-se início à prece. Os primeiros apelos, evocativos de um pai morto, são gerais e sobretudo interrogativos, a marcar a hesitação daqueles que se confrontam com a anormalidade de uma situação (315-339). As dúvidas já antes expressas por Electra regressam: Que palavras pronunciar? Que oferendas fazer? Em brados sonoros, que vençam a distância, os filhos de Agamémnon procuram também uma outra aproximação, a que une as vítimas do crime e da injustiça que frutifica na casa dos Atridas. Um porque vítima de assassínio, outros de espoliação e de exílio, todos se encontram irmanados por um ressentimento comum. E se os lamentos são entoados pelos que são do mesmo sangue, de filhos para pais, o clamor dos vivos não dá descanso aos mortos, o eco entre ambos é inevitável.

O canto que se segue concretiza os agravos que atingiram Agamémnon (345-37I). Omitidas todas as censuras ao comportamento irreflectido de Agamémnon ou às culpas acumuladas, a memória restringe-se ao guerreiro valoroso. Pela glória conquistada na cidade de Príamo, era-lhe devida uma morte condigna, caído no campo de batalha como um herói entre heróis, mantendo ilesa a sua honra. Assim a glória contagiaria os seus herdeiros e a casa, que se via compensada da perda de um senhor. Mais do que vítima da morte, Agamémnon sofreu um ultraje indigno da memória de um triunfador. 
Da utopia de um desejo, de que outro tivesse sido o desfecho da campanha contra Tróia para o seu vencedor, o coro chama os filhos da vítima à realidade próxima, a dos agravos de que, perante o desaparecimento do senhor de Argos, os seus herdeiros são objecto (378-399). Este é um ponto crucial no kommos, aquele em que os contornos de uma vingança que urge, por todas as razões humanas e divinas, cumprir, se impõe em todo o seu horror. Uma invocação a Zeus, senhor da justiça, legitima o castigo do culpado, mesmo que seja sobre uma mãe que o golpe da punição recaia. Orestes confessa neste momento o aspecto doloroso que, no seu caso, o cumprimento da regra universal comporta: a vingança, para o filho de Agamémnon, é matricídio. $\bigcirc$ coro e Electra tentam apagar o efeito negativo desta tomada de consciência, refugiando-se no regozijo de lançar o seu canto de luto sobre 'a mulher imolada' como sobre 'o homem ferido de morte'. Com esta correcção, o acto configura-se como a legitimidade de punir a mulher que matou o homem e marido, diluindo o peso sacrílego do que verdadeiramente está em causa, vitimar uma mãe. A evocação dos deuses e da justiça por entre clamores de ódio e de raiva procura evitar que recue, como uma necessidade a que os humanos aderem, o acto de vindicta. Todavia o horror está lançado e a hesitação tende a instalar-se de novo (400-422). O coro lembra a imposição fatal das Erínias, as deusas das sombras que salvaguardam os direitos dos mortos. $\bigcirc$ sangue derramado que a terra bebe acorda-as para o cumprimento de uma missão infalível, a reclamação de mais sangue. Orestes reconhece a verdade desta ameaça, mas interroga-se, atónito e horrorizado. As vozes femininas incentivam-no, e Electra lança o argumento decisivo: uma mãe que não é mãe porque não respeita os direitos dos filhos e neles desperta ódio é, também por essa culpa, merecedora de crueldade. Este brado cala reservas e se alguma breve suspensão implica, o adiar de uma resposta de Orestes, cala fundo e orienta a vontade masculina, ainda imatura, do filho de Agamémnon, no sentido de uma decisão final (423-455). Mais longa, esta meditação traz ao matricídio as atenuantes que um amontoar das culpas de uma mãe produz. $\bigcirc$ coro reduz-se a uma expressão firme de dor e revolta: o ritmo dos seus gestos acelera-se, as mãos ferem o peito com mais determinação, os golpes são mais fundos e sonoros. Por via de uma encenação exterior, o sofrimento intensificase e contagia-se. Perante os filhos vai-se tornando nítida a enumeração e a consciência dos agravos sofridos de uma mãe: que ousou imprudentemente matar um rei, que era também o seu marido, de uma forma desonrosa e 
privada das homenagens devidas à sua condição. A omissão de uma legítima homenagem é hierarquizada: ficaram calados os lamentos de um povo e as lágrimas de uma familia. Para além de rei e de marido, a vítima era também um pai, cuja perda traz dor e dever de vingança. Com esta nova tomada de consciência, mais funda e sentida, as hesitações estão finalmente abaladas e a decisão, já antes tomada, conhece a adesão inteira por parte do executor. Para além de todas as dificuldades que o acto comporta, Orestes proclama (435-438): 'Esse destino infame que ela infligiu ao meu pai, ah, ela vai pagá-lo, por acção dos deuses, e por aç̧ão do meu braço. Depois de a matar ... que eu morra também!'. Todos os horrores que a decisão de Orestes comporta foram confessados e, de alguma forma, exorcizados. Orestes atingiu a lucidez plena que a avaliação do seu dilema exige: matar uma mãe para cumprir um acto de legítima e necessária vingança, ou deixar impune um crime que desonra a memória de um rei, de um marido e de um pai, eis a opção que se the coloca. E mesmo se foi já a determinação da vingança que o trouxe a Argos, conduzido por Apolo e pela sua vontade, a consciência traz agora ao seu acto uma nova força, depois que um juízo de tudo o que está em causa lhe deu a garantia do inevitável. Electra soma ainda alguns agravos pessoais, as humilhações que a não pouparam. Mas essas são agora supérfluas, quando outros valores mais imperativos se impuseram.

Por fim, o tom do kommos ganha uma vibração extrema (456-475). O defunto é de novo invocado, já sem dúvidas nem argumentos justificativos, mas tão só como colaborador de um acto iminente. $\bigcirc$ coro dirige-se desta vez também ao morto, para que manifeste a sua presença e aprovação. Mas ainda que a presença de Agamémnon seja desejada - 'vem à luz, traz-nos o socorro contra os teus inimigos', 459-460 -, Ésquilo não produz a aparição em cena de um fantasma. Algum apaziguamento, que permite um diálogo com o morto, mostra que a sua atenção foi conquistada e que, ainda que dentro do seu túmulo e no silêncio da morte, o espírito de Agamémnon está presente e colhe as preces dos seus (479-509). Os pedidos tornam-se mais concretos: a recuperação do trono de Argos pelos seus legítimos detentores. Ao morto é garantida a retribuição: as honras e os rituais de que até agora se viu privado. Cada um reintegrado nos seus direitos, a justiça poderá então reinar de novo na casa dos Atridas. Pelo menos no que depende das vontades dos vingadores humanos, esse desfecho está garantido. Esta sintonia anima de alguma forma o espírito do morto, corporizado em Orestes, o procurador da sua causa. 
Tem sido objecto de longa controvérsia o sentido real deste longo canto, nos seus objectivos e na sua intervenção no desfecho da peça. As opiniões dividem-se a propósito da experiência de Orestes neste momento: será que o filho de Agamémnon está a tomar uma decisão pressionado pelas mulheres do coro e pela irmã, ainda hesitante na sua vontade própria? Será que esta hesitação de Orestes questiona a moralidade da ordem de Apolo? Mas de facto a decisão de Orestes estava tomada antes do kommos, e este parece servir sobretudo para aprofundar essa determinação e para clarificar o sentido de um acto próximo, que é o fulcro da tragédia. À ordem de Apolo, Orestes vai aderindo com mais e mais implicação pessoal, à medida que ultrapassa as reticências morais que um matricídio inevitavelmente coloca. No progresso envolvente do ritual, o jovem concilia-se de plena vontade com a missão que Ihe tinha sido atribuída e adere sem reservas aos deveres para com os deuses e os mortos. Nas palavras oportunas de A. Lebeck ${ }^{31}$ : 'A decisão de Orestes não é estática nem rígida. Cresce em profundidade, toma uma nova dimensão, à medida que ele encara o matricídio e explora $\circ$ dilema da legitimidade de um acto que é criminoso'.

Depois desta evocação sentida do espírito de Agamémnon, a Oresteia proporciona a aparição efectiva de um espectro, o de Clitemnestra, em Euménides. Esta é uma peça onde avulta o divino: Apolo e Atena, como deuses olímpicos, patrocinam dos seus temenoi a redenção de um vingador e o estabelecimento de uma nova ordem de justiça, em confronto com as defensoras da ordem tradicional - obediente à regra da reciprocidade - que é preciso render a um outro projecto de cosmos, acordado entre deuses e homens. $\bigcirc$ conflito é agora cósmico e o progresso uma marcha dolorosa das trevas para a luz. $O$ vingador Orestes, ainda manchado de sangue, sai de Delfos a procurar em Atenas a absolvição, sob o patrocínio firme de Apolo. No templo do deus dormem, como visão de horror, as Erínias. É neste breve espaço de trégua, que apenas adia a perseguição das deusas tenebrosas contra o matricida, que a aparição do fantasma da vítima ocorre ${ }^{32}$. A sua vinda é espontânea e inesperada, sem que seja necessário chamá-lo do fundo das trevas, até porque a sua presença entre os vivos não é desejada. A memória de Clitemnestra colhe os ódios gerais e, mesmo se tenebroso, o matricídio foi entendido como um

31 Op. cit., 113.

32 Sobre a discussão a propósito da vinda efectiva de um fantasma a cena ou da sua representação como uma simples voz off, vide Taplin, op. cit., 366-367. 
acto necessário. A ruptura entre a rainha de Argos e o mundo dos vivos é total. Talvez mesmo a sua aparição no ambiente sacro de Delfos, depois da epifania de Apolo diante de Orestes e do público, seja cenicamente menos vibrante do que a de Dario em Susa. Mas a sua função dramática é poderosa porque lhe cabe produzir, ao vivo, a imagem do que é a justiça tradicional: a reivindicação da vítima de um crime, junto das deusas vingadoras, de um castigo equivalente para o autor do golpe. É portanto a mulher de Agamémnon quem comanda a entrada das Fúrias na acção. Clitemnestra comenta todo o processo, desde o despertar das deusas até ao seu envolvimento pleno na perseguição do criminoso (94-142). O fantasma está diante das Erínias adormecidas, é tempo de enunciar os agravos sofridos: o desprezo que merece alguém apodada de 'assassina' mesmo entre os mortos e que erra sem encontrar a paz; mas além de assassina, esta mesma alma é também vítima, sem que o matador, o seu próprio filho, sofra por sua vez de igual desprezo.

Neste reino todo ele de morte, o diálogo mesmo assim não é fácil. Não se trata aqui de quebrar a barreira da morte para fazer chegar às trevas os apelos dos vivos; a fronteira é a que separa o fantasma de uma mortal - ré e vítima ao mesmo tempo - das deusas da vingança, explicitada pelo sono. Clitemnestra quer penetrá-lo pelo sonho, que coloque diante dos espíritos, mais lúcidos na tranquilidade do sono, a imagem de uma vítima coberta de golpes (103-104). Quão longe está a Clitemnestra do Agamémnon, que não acreditava em sonhos, desta que agora se vê encarnada num! Sem ter no entanto perdido uma energia natural que a obriga, mesmo como espírito, a incitar as deusas vingadoras. As oferendas que os rituais de apelo às trevas exigem são, quando o executante é também um espectro, apenas uma lembrança, das que em vida, por suas mãos, penetraram a terra. Clitemnestra pode recordar o rigor com que executou um ritual pacificador: a selecção rigorosa das libações de que o vinho, como estimulante, foi erradicado, a hora recolhida da noite, no recato que se exige para seres que reinam nas trevas. Por essas homenagens, já distantes, o fantasma exige agora o contributo das deusas contra o seu inimigo. Repete assim de alguma forma o ritual que Coéforas mostrou sobre o túmulo de Agamémnon, destinado a despertar a conivência de uma força poderosa para um terrível acto de vingança.

Depois da avaliação da legitimidade de um pacto - o que solicita com oferendas a intervenção das Erínias -, Clitemnestra inicia os chamamentos. 'Ouvir' e 'chamar' insistentemente repetidos exprimem a distância tradicional 
em relação à morte. A cada novo apelo, a cada acusação as deusas reagem com sons terríveis e progressivamente mais despertos, rugidos seguidos de gritos inarticulados. A luta de Clitemnestra é contra o sono que há-de libertar as suas presas, sono que se vai permeando de uivos e de movimentos, com a lentidão natural ao quebrar da letargia da morte. Por fim as palavras sobrepõem-se aos simples sons e a ideia de perseguição insinua-se no espírito das Erínias. Mais lentos, os membros vão obedecendo com o estímulo incessante da vítima. Quando as deusas finalmente se agitam, prontas à corrida no encalço de Orestes, o fantasma esvai-se com a mesma rapidez com que chegara. Sem que haja diálogo entre deuses e mortais, a sintonia é ganha pela repetição de agravos e de apelos. A missão do espectro está cumprida, porque já em seu nome as Erínias se mobilizam, prontas a agir.

Para além das peças conservadas, há sinais de que outros fantasmas possam ter invadido a cena de Ésquilo, produzindo um efeito a carácter com o espírito sacro do seu teatro e certamente também repetindo um processo dramático de sucesso. Apesar de o texto conservado da Psychostasia se reduzir a três palavras (frs. 279, 280, 280a Radt), os testemunhos conservados sugerem que, em cena, Zeus, acompanhado de Tétis e da Aurora, procedia à pesagem das almas dos filhos das deusas, Aquiles e Mémnon; decidia-se assim qual deles iria perecer em primeiro lugar. Plutarco (Moralia 16f-17a) salienta a inspiração homérica desta produção esquiliana, que retoma a llíada 22. 210 sq..., onde Zeus sujeita a pesagem semelhante Aquiles e Heitor. Comparando o testemunho de Plutarco com as imagens em vasos que reproduzem a mesma cena, Taplin 33 discute a identidade dos guerreiros, que nas pinturas são identificados com Aquiles e Mémnon tal como na cena da tragédia, como também defende o motivo épico como remontando à Aithiopis e não à llíada. Por seu lado o deus que sustenta a balança oscila entre Zeus ou Hermes, com a autoridade que lhe cabe como deus dos mortos. Todos estes elementos apontam para um dado incontroverso: a popularidade de um motivo a que a cena de Ésquilo deu um acolhimento que imaginamos memorável. Deixam também manifesta a controvérsia sobre uma peça que exigia extremos de ousadia, talvez incompatíveis com o que julgamos ser a prática teatral de Ésquilo. A presença do próprio Zeus em cena, como a maquinaria necessária à pesagem das almas, encontram-se neste número. De qualquer maneira, mesmo que os espíritos 
fossem trazidos a cena, a sua atitude inerte parece bastante diversa dos modelos atrás analisados.

\section{Os Homens}

\section{A imagem do poder - o soberano}

Herdeira directa de uma tradição épica, a tragédia esquiliana trouxe à cena algumas das grandes figuras dos heróis do passado, os velhos guerreiros que o mito imortalizou. Mais consistentes agora na imagem que dão como mortais responsáveis pelo destino das comunidades humanas que governam, perante os deuses e os cidadãos, é sobretudo em tempo de guerra que a sua actuação se exprime. Um código de elementos temáticos e cénicos envolve o retrato destas figuras e daquela que é a sua experiência de vida convencional. Deles faz parte, antes de mais, a ideia de justiça ou de oportunidade que condiciona cada campanha. A sua maior ou menor legitimidade determina as reacções que a rodeiam, da parte dos deuses e dos homens. Sinais diversos, de aprovação ou de censura, caracterizam a relação do chefe com o universo em geral, como em particular com a comunidade a que preside. Para além das condicionantes que determinam a realização de uma campanha, o seu percurso será revelador de um processo em que, acima das qualidades que fazem de um guerreiro um herói superior, se impõem sobretudo as regras de um diálogo que ele terá inevitavelmente de estabelecer com as forças que o cercam e com as regras que determinam a ordem universal. Só um justo equilibrio, que corresponde a um ideal inatingível, poderia depor na cabeça do vencedor uma coroa perfeita de vitória. Essa nike, porém, é alada e fugidia, porque às limitações humanas nenhum prémio completo pode corresponder. É sobretudo na contingência do destino e na ignorância dos limites da sua condição que assenta o percurso de um herói que, porque é também uma criatura humana, se não isenta da eterna regra que o coro do Agamémnon tão oportunamente enuncia: 'Aprender pelo sofrimento'.

São reveladoras de um enorme poder e da ambição que sempre o acompanha aquelas expedições que têm a conquista e o domínio de outros povos por objectivo. É a prosperidade que as determina, porque exigem uma grande mobilização de meios e comportam riscos enormes para quem as põe em marcha. Exigem um tempo longo de execução, decorrem em paisagens 
longínquas que muitas vezes as fronteiras marinhas distanciam. São, portanto, em todos os seus contornos, um quadro de excesso: ostentação de um poder ferido de uma ambição condenável, e demonstração de uma injustiça que estimula ao ataque de quem se considera mais fraco e a cuja demolição se não colocam limites. No projecto, como na execução, as expedições de conquista são exuberantes de grandeza, como também reveladoras de resultados imprevisíveis. Têm por cenário a cidade do conquistador, ansiosa pelo silêncio de uma longa ausência e na expectativa de um resultado. Sobre este temor branco que suporta a hesitação, correm imagens sucessivas: aquelas que, pela memória, repetem o espectáculo magnífico da partida, por contraste com outras, que advêm de notícias, da adivinhação ou da profecia, e que se exprimem por informações controversas ou enigmas obscuros. São, portanto, na sua essência um percurso bem marcado por etapas, que conduzem da expectativa coberta de sombras à claridade de uma revelação plena do que é o desfecho reservado à ambição humana.

Xerxes e Agamémnon cumprem um destino paralelo como senhores poderosos que são, ainda que um bárbaro e o outro grego. $O$ que significa que as regras que regem a vida dos soberanos são universais e se aplicam indistintamente. Cada um deles se insere num contexto cultural com uma expressão diversa. Xerxes reveste para os Gregos o perfil palpável de um chefe inimigo, que os espectadores de Ésquilo tinham visto pisar o seu terreno e ameaçar a sua liberdade. Nele dominava a carga histórica que convém a alguém cuja actuação está ainda viva e presente nos testemunhos e nos cenários de guerra. Agamémnon, o grande senhor de Micenas, tinha a consagrá-lo séculos de tradição e a sua história de conquistador de Tróia vinha já coberta de mito e de distância. Mas, na cena de Dioniso, um e outro conhecem um tratamento semelhante, porque afinal o mito mais não é do que a leitura paradigmática da experiência concreta da humanidade. Em Persas, como no Agamémnon, a cena decorre no palácio dos monarcas ausentes e a tonalidade de fundo é a da nostalgia e da angústia causadas por um afastamento longo e silencioso. Está lançada a primeira nota dramática comum neste modelo de peças que se alimentam de uma campanha no exterior: o temor surdo e geral que a falta de notícias ocasiona. A sua expressão afirma-se a várias vozes: a da competência de alguns que ficaram, os velhos, porque a idade lhes não permitiu participar na guerra; e a da sentimentalidade das mulheres, cuja condição é contagiada pela expectativa que invade as casas. Traduzida para o elenco das duas tragédias, 
esta função pertence ao coro de velhos conselheiros e à rainha regente. Constitui, em qualquer dos casos, o tema de abertura.

Em Persas, Ésquilo dá ao coro de velhos prioridade absoluta porque a tragédia se inicia com o párodo ( 1 - | 54). $O$ tom alterna entre o descritivo e o especulativo. Apesar de um íntimo tremor de alma, os conselheiros persas descansam na evidência do ouro, que clama o poder superior da corte de Susa, e na memória do potencial de forças que se relata num extenso catálogo de unidades militares, denunciadoras de uma imbatível capacidade bélica.

Da prioridade dada à Pérsia como um império magnífico e combativo, que devolve a imagem firme de um poder sólido, o foco incide no soberano, aquele de cuja vontade depende a sorte de um projecto bélico. Do carácter objectivo da narração, o coro prossegue com o especulativo, procurando imaginar os movimentos de um monarca (65-86) - o seu soberano -, que é apenas o exemplo imediato de um thourios archon (73; cf. 718, 754), 'um senhor impetuoso'. Sem expressar censuras, os conselheiros podem denunciar os pontos críticos de uma investida em que reside o motivo do perigo e da apreensão. Fazem-no com segurança, porque conhecem a mentalidade persa e os contornos do objectivo em causa; mas não deixam de sugerir, no exemplo concreto em que se inspiram, o retrato convencional do comportamento do poder humano.

À frente de um exército imenso e de terrível capacidade demolidora, o rei caminha para uma aventura desmesurada, que exige a travessia do mar e a ofensa dos limites colocados ao ímpeto humano pelas fronteiras do reino de Posídon. Tudo é excessivamente grande na aventura: o alvo a atingir, tão só o mundo inteiro; o potencial de forças envolvidas, 'um rebanho monstruoso'; o risco máximo de uma campanha que movimenta todos os recursos militares disponíveis, em terra e no mar. Toda a força de alma que é própria destes mortais a quem o destino elevou se thes concentra nos olhos, profundos e sanguinários, animada pelo potencial que os rodeia e que se move sob o seu gesto de comando. Esta é bem a imagem da responsabilidade plena de um chefe, em consumação de um destino superior, que por isso não deixa de ser simplesmente humano. E como humano que é está sob a observância atenta dos deuses, que não deixarão de o avaliar e de o reprimir à medida dos limites que o equilibrio universal exige. Não o poupam também as opiniões humanas, daqueles que sabem medir a dimensão dos riscos e o excesso da ousadia, porque pensam com inteligência e sophrosyne, nem tão pouco as suas vítimas, 
que temem com a agudeza de previsão que o sentimento dá. Assim se reparte a população que aguarda, de velhos e de mulheres.

Sinais do além vêm trazer ao ambiente de dúvida novas apreensões. Ao temor humano, os deuses acrescentam manifestações da sua vontade e falam em cena através do testemunho dos homens. Em Persas, a voz divina soa pelos lábios de Atossa, através de um sonho (vide Sonho) e de um presságio, e pela voz distante do fantasma de Dario. Enquanto os sonhos têm um carácter mais personalizado na forma secreta como aparecem, na intimidade de um leito, os presságios ganham uma dimensão pública, porque muitas vezes se manifestam através ou em simultâneo com um ritual. É precisamente quando, sobre o altar, Atossa homenageava com oferendas os deuses protectores, que o prodígio acontece (20I-210). Para se exprimir, o presságio usa símbolos, uma luta entre duas aves. Tudo é movimento no quadro fantástico: uma águia, a imagem do poder (persa neste caso), em fuga, perseguida por um milhafre, menos potente mas mais rápido e ágil, que a ataca sobre a cabeça e lha desmembra, incapaz de opor uma resistência firme. Assim se exprime a noção de que um grande poder, aquele que a senhora dos alados, ave de Zeus, representa, não é imune à resistência e ímpeto de uma força na aparência mais débil, mas que esconde uma agilidade feroz e determinada. Nos dois pratos da balança, promessa de êxito e temor do fracasso oscilam, numa tendência já manifesta para o lado onde as sombras representam maior peso.

A campanha de Agamémnon contra Tróia segue, em Ésquilo, um padrão semelhante, mesmo se, no pormenor, alguns elementos se invertem. Compete também à voz do coro (40-103) estabelecer um primeiro momento de apreensão, que não advém de um longo silêncio não quebrado, mas exactamente da surpresa causada por um primeiro sinal, ainda dúbio, que o facho luminoso acaba de trazer a Argos. Dez anos passados, os velhos recordam a motivação de uma campanha que pôs em marcha, tomados da fúria da vingança e escudados no cumprimento dos desígnios de Zeus Xenios, os dois Atridas. Não é nos olhos que se lhes concentra desta vez a potência sanguinária, mas no grito terrível, expressão de uma fúria incontrolável (47). O elemento da vingança por uma ofensa cometida por Páris contra os homens e contra os deuses - o rapto de Helena contrário à lealdade devida a um anfitrião generoso e à justiça com que Zeus protege a sagrada norma da hospitalidade - trazia a esta campanha uma justificação ou pelo menos um vislumbre de legitimidade. Com este pormenor, Ésquilo enriquecia o tema da motivação de um conflito, 
que põe em discussão a medida do que é uma guerra legítima ou simplesmente um ataque movido pela ambição e pela desmesura.

Em tom de um profundo lirismo (104-159), o coro conduz a nossa leitura sobre o sentido deste projecto militar, através dos sinais com que os deuses não deixaram de responder à interrogação humana. $\bigcirc$ presságio acompanhou, no caso do ataque contra Tróia, o momento da partida marcando desde o início o desfecho da aventura. Perante os chefes atridas, à frente da juventude grega no seu todo, os deuses falaram do alto dos céus numa imagem que se impôs à colectividade (thourios ornis, I I2; cf. Persas 73). Sobre o palácio voaram duas águias, o símbolo claro do poder duplo do comando atrida. Sem hesitação, as duas senhoras do céu caíram sobre uma lebre prenhe, indefesa e fraca, que se quedou aniquilada sem resistência. Era a vitória que a visão divina prometia, mas não isenta de reservas e de perigos. Na lebre prenhe que as águias destruíam, num ataque genocida - 'imagem de alarme e de esperança ao mesmo tempo', 145 -, estava expressa, ao lado do sucesso, uma ofensa a Ártemis, a senhora das crias e da renovação das espécies, e garantida a fúria punitiva da deusa. Para o crime que o presságio anunciava, a filha de Zeus exigiu, desde logo, a retribuição no sacrifício de uma outra cria, a filha do comandante do exército, Ifigénia, para que o custo da guerra, simbolicamente contabilizado, redimensionasse o impulso guerreiro e impusesse a ponderação. Com a possibilidade de decisão, Agamémnon assumia também a plena responsabilidade dos seus actos ${ }^{34}$. Ao escolher entre o que the parecia um dever de honra militar, que o obrigava a prosseguir a campanha, e os seus deveres de homem e de pai, que the exigiam a protecção da filha, o rei de Micenas preferiu sacrificar Ifigénia, talvez porque uma ambição maior que todas as considerações lho ditasse. A persistência cega que empurrou os Atridas para a loucura destruidora da guerra, apesar de todos os sinais de desagrado divino, repercutiu-se igualmente sobre os homens, tal como em Susa. A prudência da velhice exprimiu-se em apreensão e reserva, ao lado do temor feminino; mas desta vez a cólera, mais do que o pavor das perdas humanas, prometeu ao vencedor um outro saldar de contas, que pagasse vingança com vingança.

34 Esta é uma das discussões fundamentais e mais controversas na interpretação da peça: a da efectiva liberdade de escolha de Agamémnon e, em consequência, a da sua responsabilidade ou culpa. Sobre o assunto, cf. H. D. F. Kitto, Form and meaning in drama (London reimpr. 1959) I-38; A. Lesky, 'Decision and responsibility in the tragedy of Aeschylus', in E. Segal, Greek Tragedy (Oxford reimpr. 1991) 13-23; H. Lloyd-Jones, 'The guilt of Agamemnon', ibidem, 57-72. 
A confirmação das suspeitas que a distância ajuda a construir chega pela mensagem de um arauto. Regressado do campo de batalha, ele é a testemunha fiel dos acontecimentos e o seu relator minucioso. Através da sua narrativa, o retrato do soberano, agora em plena actuação, prossegue.

Desde as primeiras palavras o arauto persa dá o tom ao seu relato: a campanha de Xerxes na Grécia acabou num desastre total (249-5I4). Morte é a palavra que melhor exprime a dimensão da catástrofe, deixando prever, na notícia de que o soberano sobreviveu, a futura chegada de um chefe sem exército, numa solidão humilhante. Um longo catálogo de baixas contrapõe-se àquele que recordava a mobilização inumerável das tropas, no momento da partida. No campo de batalha, Xerxes defrontou duas forças decisivas: a ira vingativa dos deuses e a perspicácia defensiva dos Gregos. Aliadas numa causa de justiça, estas duas frentes aniquilaram o poder, apenas material, do persa. Confrontado com o desmoronar de um sonho e com o aniquilamento do seu povo, Xerxes cedeu à dor e antecipou, no campo de luta, os gestos de sofrimento que, no seu regresso ao palácio, irão cobrir a imagem do derrotado: no meio de longos lamentos, o rei esfarrapa, em sinal de luto, as suas vestes de comando e de prosperidade (465-468; cf. 199, onde já Atossa, em sonhos, vira a imagem do filho coberta de andrajos).

As notícias que, no Agamémnon, relatam a campanha contra Tróia são tão ambíguas quanto a própria previsão que lhe acompanhara o arranque. Tratavase, à primeira vista, de um êxito, o devorar, incontroverso, de uma presa fácil e submissa ao poder do invasor. Na sua luz radiosa, um primeiro mensageiro o facho luminoso -, sem palavras, o tinha anunciado. Este é o primeiro sinal da tragédia, a luz enganadora da vitória (22-30). Clarão que não basta para calar todas as dúvidas e suspeitas que o presságio de outrora, confirmado pelo passar doloroso dos anos, tinha produzido. Desde o Vigia ao coro, à rainha, em todos a luz do facho, que prossegue a sua tarefa de mensageiro no interior de Argos, desperta uma alegria moderada, a que não é estranho um temor vago, que não deixa de avolumar-se: primeiro porque, nas palavras do servo fiel, o regresso do vencedor virá encontrar uma casa perturbada e sombria à sua espera; depois, na intervenção do coro, porque reanima a imagem ameaçadora dos presságios de outrora; por fim, nas palavras de Clitemnestra, porque the não é estranha uma actuação desmedida na sua violência, que acrescentou às exigências limitadas de um castigo devido a Zeus Xenios a demolição gratuita de vidas humanas e mesmo dos bastiões erguidos em honra dos deuses. De 
facto cabe, no Agamémnon, à rainha (320-350) especular sobre os acontecimentos em Tróia, como antes o coro de Persas em Susa. Antes que a descrição minuciosa chegue pela boca de um arauto humano, que explicite no pormenor o sentido do sinal luminoso, já Clitemnestra antecipa, em previsão, algumas imagens da vitória. Não lhes faltam também sinais de perigo que permitem encontrar, subjacentes aos seus fulgores, a evidência de terríveis sombras de desastre. $O$ grito feroz com que os Atridas exprimiram o ímpeto de guerra na hora da partida (32l; cf. 47) repetiu-se no momento da vitória. Cercados dos soluços dos vencidos, os Gregos responderam com a alegria do saque e a tranquilidade de uma primeira noite dormida em paz. A que Clitemnestra acrescenta um voto (338-340): 'Que a piedade deles respeite ao menos os deuses nacionais dos vencidos e os seus santuários, e não terão que temer o desastre depois da vitória'.

Um arauto chega enfim, para coroar de certezas todo este processo ambíguo de luz e de sombras (503-680). O coração brilha-lhe, por um fugaz momento, de alegria no regresso a uma pátria tão saudosa e há dez anos perdida na distância. É a recepção devida a um vencedor que ele reclama, radiosa de brilho como a vitória merece. Mas como manter incólume essa luz, quando as sombras se amontoam? Mais do que um vencedor, o soberano é um destruidor, dos templos dos deuses todos sem excepção e da raça troiana que se apagou do solo que ocupava (cf. Persas 807-7I2). As piores previsões de Clitemnestra estavam confirmadas. A vingança justa contra Páris estendia-se a todo um povo inocente que rúa sob a raiva desmedida do invasor. Mas para além de todas as perdas que impôs ao inimigo, Agamémnon não poupou a vida dos seus próprios homens que, durante anos, sujeitou ao sofrimento e à morte em nome de um projecto de ambição pessoal.

Produzida, em memória ou em imaginação, a campanha desde o início ao desfecho, ao público está reservado o espectáculo do regresso do herói: vencido ou vencedor, as aparências tornam a sua presença tão dúbia quanto a fluidez de um retrato à distância. Xerxes exibe, sob o aparato dos andrajos, o sofrimento de uma autoridade que soçobra com um estrondo de agonia, sem mesmo assim prescindir de um poder que por herança the pertence; Agamémnon esconde, no fulgor vistoso das púrpuras, a ameaça de uma violência que agora vai impor a morte e a desordem no palácio do vencedor. São assim, superiormente paradoxais, mas justos, os desígnios dos deuses e do destino. 
Do ponto de vista teatral, a presença do soberano em cena, depois de tão alongada especulação sobre a sua ausência que o coloca no centro das atenções gerais, ocorre debaixo de uma luz intensa. É minuciosamente preparada nos pormenores exteriores, como espectáculo, e interiores, como sofrimento repartido com aqueles que o cercam.

Inspirada na evidência de sonhos e de presságios, Atossa define o acolhimento devido ao monarca de regresso a Susa, qualquer que seja em fim de contas o resultado da campanha (2||-2|4): 'Vocês bem o sabem, se o meu filho tiver sucesso, será um herói sem igual; se fracassar, não tem de dar contas ao país e, desde que regresse, será para sempre o senhor desta terra'. Logo o arauto vai responder a esta dúvida: Xerxes irá voltar, mas, do campo de batalha, a imagem que a testemunha nos projecta é a de um soberano dobrado ao peso da derrota e da morte, que exprime em lamentos e no rasgar das vestes o sofrimento por um desastre que é em parte obra sua. $\bigcirc$ tempo que medeia até à chegada efectiva do monarca preenche-o Ésquilo com uma consulta a saberes superiores, não de um qualquer oráculo, mas do velho monarca Dario, modelo de experiência e de sensatez política. Mais do que interpretar ou prever os acontecimentos e a sua repercussão, o fantasma dá uma outra imagem do poder que, pelo contraste, acentua o excesso da que o seu filho representa. Porque sensato e moderado, o velho rei garantiu ao seu povo, na versão de Persas, um equilíbrio entre segurança governativa e obediência voluntária dos súbditos. Como voz da sabedoria que encarna, passado e futuro da Pérsia ganham, através da sua leitura política, um sentido profundo e o valor de uma profecia verídica. A condução dos interesses persas nesta campanha foi denunciadora de uma leviandade juvenil e de excessiva ambição, que os deuses não deixaram de punir com rigor. Mas o futuro, apesar de tudo, será ainda o da autoridade do mesmo Xerxes, que é preciso, como afirmara Atossa, restabelecer no trono e no ascendente régio apesar do revés sofrido. $\bigcirc$ milagre deve exprimir-se por um trocar simbólico de vestes, as do vencido pelas do monarca reinvestido no poder. É esse o conselho de prudência de Dario, que a rainha deve quanto antes assegurar (832-836); sem que o fulgor meramente aparente dos trajos multicores tenha $\circ$ condão de apagar o que é o sentir profundo do vencido, uma alma coberta de farrapos. Mas as aparências são necessárias ao poder, mesmo em tempo de crise, porque constituem uma espécie de último bastião de resistência. Assim o entende Atossa, no que talvez seja a expressão de um sentimento geral (845-848): 'Ó destino, quantos 
sofrimentos me penetram diante de tão grande miséria! Mas a pior de entre todas as desgraças é a humilhação que lhe causam as roupas que agora cobrem o corpo do meu filho'.

Tudo está cuidadosamente preparado para a entrada de Xerxes, solitário e entregue à dor profunda da derrota. Mas este é também um ponto muito controverso na avaliação cénica do espectáculo. Será que de facto Xerxes aparece em trajos régios, como o desejava o par real, ou em farrapos? $\bigcirc$. Taplin ${ }^{35}$ sintetiza a questão nestes termos: em 849-85।, antes de se ausentar com conhecimento da chegada iminente de Xerxes, Atossa anuncia dois propósitos: o de ir ao palácio buscar vestes condignas e o de 'tentar encontrar' o seu filho recém-chegado. Para concluir que a rainha o não encontra e que portanto Xerxes aparecerá (909) vestido de farrapos. Esta promessa frustrada de Atossa seria apenas uma oportunidade de valorizar o efeito simbólico do trajo que o monarca usa. Apesar de reconhecer a estranheza desta promessa não cumprida, Taplin insiste em que só uma alteração no texto permitiria que, fora de cena, o encontro mãe / filho fosse admissível. Depois de uma insistente referência às vestes luxuosas que Xerxes rasgou no campo de batalha ${ }^{36}, 0$ próprio em cena chama a atenção para 'o que resta dos seus trajos de outrora' $(1017,1030)$. Será desnecessário encarecer o efeito visual dos farrapos, como imagem de ruína que irmana o rei com todo um povo destroçado. Mesmo se o poder de Xerxes não está em perigo, os lamentos que partilha com o coro são a expressão de uma harmonia dolorosa: da reprovação discreta mas sentida de um povo, perante a ambição irresponsável do comandante aparatosamente punida pelo destino. Mais do que um sentido pessoal, como é aquele que afecta também Agamémnon, o senhor de Susa encarna todo um império e a crise que a sua insensatez provoca tem a dimensão da ruína de todo um povo.

Não é menos cuidada a preparação devida à entrada do conquistador / destruidor de Tróia que é Agamémnon. $\bigcirc$ triunfo próprio de um vencedor

35 Stagecraft, 96-98. Sobre a mesma polémica, cf. ainda Taplin, ibidem, 122- 123. O argumento que recorre ao testemunho de Aristófanes (Rãs 1061-1068) para excluir os farrapos do teatro de Ésquilo e os considerar típicos dos excessos cénicos de Eurípides não é evidentemente conclusivo. $O$ facto de ser sobretudo Eurípides a utilizar este recurso, ou de o ter mesmo levado a extremos de aparato, não exclui a possibilidade de, em ocorrências mais raras e mais sóbrias, ele ter sido também usado por Ésquilo e por Sófocles. No caso de Ésquilo, é aliás muito provável que o seu Filoctetes os usasse, como também a deusa Hera, disfarçada em sacerdotisa coberta de andrajos, em Sémele (cf. Taplin, 122).

36 Vide supra 92. 
ecoa, ao longo da peça, em vários tons, a caminho de um clímax que o é ao mesmo tempo de luz e de aparato como de sombras e de violência. São ambíguas as coroas lançadas a um ganhador a quem a justiça não acompanha. A primeira recepção é a do alívio primário, expresso pela espontaneidade de um homem simples em nome do povo, que reconhece no brilho de um facho o sinal do fim de uma longa angústia (22-39). À luz que chega da distância, Argos deve responder com a alegria da festa colectiva, em coros incontáveis. Os gritos não faltam, mas de regozijo, dos que recebem o sinal da vitória, num progresso que recruta todas as vozes, das mais próximas, dos parentes, até ao grande clamor unido de todo um povo em euforia. Luz, canto, dança, gritos de alegria, o apertar caloroso da mão do vencedor, vibram na imaginação de um servo fiel, a quem a mesma lealdade dita um silêncio prudente, mas inesperado. No fulgor vivo da festa paira uma primeira sombra, ainda vaga e incerta.

Mais reticente, como convém à sua idade e posição, o coro regista também os primeiros sinais de júbilo, não os que brilharam do exterior, mas aqueles que brotam já no âmago da cidade (83-103). Por ordem de Clitemnestra, são os deuses quem antes de mais se quer associar à festa, todos eles sem excepção, num ritual que os faz partilhar do júbilo da cidade que protegem. Sobre os altares acumulam-se as oferendas e dos óleos sagrados erguem-se as chamas, outros tantos fachos anunciadores de uma vitória para que se pede a aliança divina. Mas apesar de um êxito que se vai tornando tão aparente, no seu brilho exterior, a alma dos velhos não encontra paz e uma angústia inexplicável oferece à festa uma resistência teimosa. Talvez porque a memória mantém viva a força dos sinais suspeitos ou infelizes, que marcaram, desde a hora da partida, este projecto. A espontaneidade que justificava a alegria vibrante de um homem simples como o Vigia não tem paralelo na personalidade dos velhos conselheiros da corte de Argos. Por prudência antepõem ao momento da alegria uma cuidada ponderação, que é também uma avaliação do preço a pagar pelo triunfo. Por isso a sua adesão é adiada, céptica da veracidade das luzes, como dos aplausos a que a sensibilidade feminina ou popular é mais aberta. Pelo peso da sua $\mathfrak{o z}$, o júbilo crescente sofre um recuo e nuvens cada vez mais carregadas ensombram a alegria do sucesso.

Um novo mensageiro chega agora, arauto com voz e testemunha directa da vitória, transmissor de uma outra opinião, a dos combatentes. A nota que o identifica é, num retomar do tom do Vigia, uma espécie de alívio a que uma alma simples é mais espontaneamente susceptível. Também para ele o fim de 
um suplício apareceu, não o da expectativa ansiosa, mas o da experiência vivida dia-a-dia no terreno de luta. Esse sofrimento chegou ao fim e em triunfo para o vencedor (5 | 8-532). Com ele regressam o brilho e a luz para se associarem à festa, no resplendor das imagens dos deuses e na fachada luminosa com que o palácio deve saudar o seu senhor. A festa como o arauto a prevê é colectiva, conhece a adesão entusiástica dos deuses e dos homens que constituem o fundamento da cidade. A luz da recepção reflecte o facho da vitória que, erguido na mão do vencedor, ilumina as últimas trevas da ausência e da angústia. No meio desta profunda alegria que o regresso à pátria exige depois de tantos anos, o mensageiro é também o portador de novas sombras. As suas palavras contrastam com o sentido reflexivo das do coro, porque são transmissoras de quadros objectivos de uma realidade de guerra. Não especulam nem interpretam, descrevem. Narram os sofrimentos do campo de batalha, os rigores do inverno, a fome, o frio e os horrores da distância para aqueles que, às portas de Tróia, conquistaram a duras penas o direito de ocupação. Por isso mesmo confirmam, com a força da evidência, o que era até então suposição temerosa ou reflexão sensata.

Por último, ainda na hora dos preparativos da recepção ao vencedor, vibra a voz de Clitemnestra com um outro tom. Ela é a senhora do palácio e a rainha de Argos; exprime portanto o sentir mais íntimo da casa e da família como esposa, mas também o sofrimento de todas as mães e viúvas de uma cidade porque soberana. A sua alegria não é isenta de uma emoção própria, exaltada e feminina, que se manifesta num grito $(587,592)$... de guerra? De festa? Para além de um envolvimento pessoal, a responsabilidade cívica que detém exige que prepare a expressão colectiva de uma cerimónia, que se executa na religiosidade dos sacrifícios e dos rituais e mobiliza toda a comunidade humana e divina (594-597). Mas nela actua também o comportamento convencional de uma esposa fiel na recepção ao marido há tanto tempo ausente. Em termos que são tão somente falsos, Clitemnestra antecipa em imaginação o acolhimento que tem em mente dispensar, antes que a cena o ofereça a nossos olhos (600-604): 'Não quero pensar noutra coisa que não seja em preparar a melhor recepção a um esposo respeitado que está de volta a casa. Que sol pode brilhar com mais fulgor para uma mulher do que a alegria de abrir, de par em par, as portas ao marido que os deuses salvaram da guerra?'

Agamémnon entra, por fim, quando os nossos olhos e ouvidos colheram já todos os brados e todos os fachos, de aplauso e de reprovação, que 
acompanham o seu cortejo triunfal. A cena enche-se agora da sua imagem, que é a do poder, da grandeza e do sucesso. A presença de Agamémnon em cena é muito breve, menos de duas centenas de versos, até desaparecer dentro do palácio, para reaparecer pouco depois como um cadáver ignominiosamente massacrado e insultado diante do público. Um tempo curto que é apenas o necessário para transformar um vencedor numa vítima justamente condenada.

É comum na cena trágica que os poderosos se desloquem em carros, elementos de aparato próprios da sua condição. Assim aparece o vencedor de Tróia (783-809), na sua entrada triunfal em Argos, acompanhado de uma cativa, Cassandra, imagem viva do saque troiano. Acolhe-o a população, representada antes de mais pelo coro, que não esconde a contradição do seu sentir. O poder desperta reverência, a superioridade causa espanto, as palavras justas para a saudar são difíceis de encontrar. Mas os verdadeiros aplausos são os comedidos, que não desmerecem nem excedem a medida certa de uma opinião honesta. Neste encontro do vencedor com os seus súbditos, cabe ao recém-chegado pronunciar uma rhesis que revele o seu estado de alma, para além da aparência exterior (8 |0-854). Os sentimentos que experimenta são confusos: primeiro o da alegria do regresso à pátria e de gratidão aos deuses pelo sucesso; mas é breve e sóbrio este momento, que dá um lugar mais amplo à avaliação da vitória. Agamémnon multiplica-se em palavras insensatas sobre os extremos da conquista: a ruína de Tróia foi total, qualquer piedade teria sido injustificada; apenas fumo marca agora o local onde uma cidade antes prosperava; a vingança desejada pelo vencedor foi plena, sem medida, a existência de um povo em troca de uma simples mulher. A recepção do coro é portanto sóbria na exteriorização discreta do júbilo, mas leal, amiga e dedicada. E apesar de o monarca se dizer atento aos sentimentos que se ocultam sob os sorrisos que The são dirigidos na hora da consagração, será este homem, por demais sensível ao fascínio do sucesso, capaz de tal lucidez? De resto, um primeiro sinal de desatenção está já patente: Agamémnon fica-se pela avaliação de uma possível animosidade humana, sem a adivinhar da parte dos deuses.

O momento de o provar está na sua frente no preciso instante em que ensaia um primeiro passo para retomar o seu lugar há tanto vazio no lar e no trono. Clitemnestra ali está, a dominar no momento de transição das homenagens públicas para a recepção privada; porque a personalidade de Agamémnon tem, para além da componente própria de um chefe, um lado pessoal que faz dele um herói dramaticamente completo. A rainha suspende-lhe o gesto e controla- 
Ihe o acesso ao palácio. É ela quem dirige, visivelmente, cada passo e cada momento da recepção. Com um sorriso nos lábios e com palavras prontas de amor, ela afirma, sem disfarce nem timidez, antes com um desassombro que fere o recato e a etiqueta, a sua devoção ao vencedor e ao marido (855-9|3). Para acautelar qualquer surpresa ou suspeita, ela própria antecipa que todo o seu entusiasmo não pareça uma lição estudada, mas a confissão sincera da lealdade de uma esposa. Da recordação, talvez autêntica, dos males da ausência, Clitemnestra atinge o momento da saudação, num caudal de elogios sem fim (895-90 I), que dirige, com exagero vistoso, ao maior dos heróis, ao salvador, ao porto de abrigo para todos os viajantes perdidos, a cidade e a sua rainha. $\grave{A}$ euforia que a domina não se misturam reticências, para o seu entusiasmo não há limites, o que faz da sua uma voz solitária entre todas as que saúdam o vencedor. Ao excesso das palavras, Clitemnestra associa o exagero de um rito triunfal: que o herói desça do seu carro sobre um tapete de púrpura majestoso, que um séquito de cativas se apressa a estender. Ao cerimonial, acrescenta a rainha uma legenda enigmática (9|0-9||): 'Que assim surja um caminho juncado de púrpura, por onde a justiça o conduza a uma recepção como ele não espera'.

Como qualquer ser humano colocado diante da tentação, Agamémnon pára à procura da resposta adequada a tão enigmática proposta. Esta é de facto, para o senhor de Argos, a hora de consagrar o seu sucesso; depois do tempo de violência, o da clarividência. $\bigcirc$ Atrida resiste e enuncia o protocolo de um triunfo (9|4-943): os elogios verdadeiros devem vir de fora, mas são suspeitos na boca dos que são chegados; o modelo de homenagem que lhe é proposto contém um requinte feminino, desajustado à masculinidade de um guerreiro; no luxo excessivo que projecta é mais bárbaro do que grego, mais próprio do asiático vencido do que do vencedor helénico; exagerado na reverência e na ostentação do bordado, este tipo de homenagem pertence aos deuses e será sacrilégio que um simples mortal o deseje usufruir. $\bigcirc$ rei é agora adivinho em causa própria, um intérprete capaz de tirar da situação que o confronta a conclusão correcta (925-928): 'É como uma criatura humana que quero ser homenageado, não como um deus. Tecidos bordados e simples tapetes são como o nome indica - coisas bem diferentes. E a prudência é dos dons divinos o maior'. Mas Clitemnestra está determinada a levá-lo à cedência; e o guerreiro superior cede aos argumentos da argúcia feminina, mas sobretudo à sedução que os extremos de aparato sempre exerceram sobre a sua ambição desmedida. E o homem que não cedeu perante a animosidade de Ártemis nem 
diante dos perigos da guerra e se prestou a cometer outros sacrilégios, entregase ao domínio de uma mulher que o atrai, com a sedução do sorriso e do elogio, a cometer um acto de que o próprio acumulara os inconvenientes (944957). Incapaz, até para consigo mesmo, de franqueza, Agamémnon cede como se para satisfazer uma vontade alheia. Como um grande senhor deixa-se descalçar pelas servas que se the dobram diante, num gesto rápido que cala hesitações, para pousar sobre a púrpura os seus pés de vencedor. E se um vago bom senso, lá do fundo da alma, ainda protesta contra o exagero de um luxo que ofende os deuses e delapida a segurança do património das familias, ele não basta para impedir aquela que é a tendência profunda da sua personalidade: um orgulho inominável. Neste momento em que pisa o tapete de púrpura, Agamémnon sela o seu destino. Num gesto simbólico que coroa o centro da tragédia, o rei de Argos resolve o último dos seus dilemas e comete o último dos seus excessos ao pisar um tapete rubro, que é grandeza e sangue, exactamente os extremos do seu destino. Com a mesma leviandade com que ofende os deuses e os homens, Agamémnon atinge também a delicadeza devida a uma esposa, ao recomendar a Clitemnestra que receba sem ressentimentos uma rival, o despojo mais precioso do saque de guerra. Solene, o destruidor de Tróia caminha sobre a púrpura, porque vencedor de tantas batalhas, mas rendido à determinação do destino e à argúcia de uma só mulher. Por isso, na hora em que se vir confrontado com o horror da sua morte, o público será chamado a entendê-la como um acto de justiça, pessoal e cósmica.

São muito diferentes as linhas em que se desenvolvem as guerras de defesa, aquelas em que a peça se desenrola no próprio cenário de combate e em que o herói se ocupa não de planear um ataque à distância, mas de proteger a sua pátria da invasão de um inimigo. $O$ poder que detém não se impõe como uma máquina de guerra ofensiva, que ameace de uma tremenda destruição um adversário fraco. Em todos os cenários de luta esquilianos, a dimensão mais imponente parece caber ao atacante, quaisquer que sejam os resultados finais da campanha. Por isso, a ambição, que é o impulso decisivo para o ataque, tem de substituir-se por outras características mais adequadas à defesa, como a coragem, a determinação e a finura estratégica. É com este conjunto de qualidades que o comandante da defesa tem de rentabilizar os seus meios, para neutralizar a investida inimiga. É-lhe dado, no contexto de cada peça, um grande espaço de actuação, que se caracteriza por uma responsabilidade isolada. Não que falte a rodeá-lo uma população também ela 
directamente envolvida e activa no conflito, mas porque é das suas decisões que antes de mais depende a sorte colectiva.

Por outro lado, aquele que era o sentimento dominante nas peças construídas sobre guerras de ataque - a angústia que uma longa falta de notícias vai fazendo crescer - dá lugar a um terror vivo e presente, que a iminência da guerra estimula. Não se trata de rememorar acontecimentos que decorreram num passado longínquo, cujo efeito se esconde por trás de uma cortina de silêncio, mas que se pressente nas emoções profundas de uma sociedade que espera ainda um desfecho. A exaltação resultava aí do acumular de anos e da inevitável angústia do contabilizar incerto de dias silenciosos. Quando, porém, o inimigo se comprime contra as muralhas de uma cidadela, o tempo tem outra medida, a da urgência e da fuga de cada momento vital. Os sentimentos correm ao mesmo ritmo, exuberantes na insegurança presente. A reacção de cada parte atingida será diversa, mas particularmente empenhada. Em consequência um coro feminino pode, neste contexto de emoção, ser mais expressivo, porque dele legitimamente se espera a vibração do terror face à presença da ameaça e um contraste de comportamento perante a racionalidade militar e política do defensor da cidade.

Mas uma guerra, na visão esquiliana, nunca se limita a um conjunto de arremetidas mais ou menos bem sucedidas entre dois campos. Qualquer que seja o lado de onde é visionado - do ataque ou da defesa -, um conflito humano coloca sempre os seus responsáveis diante de um adversário superior; um conjunto de princípios ou de regras, com o peso do transcendente ou universal, tem de ser ponderado e traz ao conflito puramente bélico um sentido mais profundo, porque o abre, de um circunstancialismo imediato, para um entendimento alargado do que seja a experiência humana em toda a sua amplitude.

Etéocles e Pelasgo são, nas tragédias conservadas, dois modelos expressivos do soberano empenhado na defesa da sua cidade. E é nítida, desde logo, a diferença na focagem; de facto Etéocles mereceu a Ésquilo um cuidado e uma atenção que o colocaram na posição reconhecida de 'o primeiro homem do teatro europeu' 37 .

Os Sete contra Tebas foram identificados pelo próprio autor, no Hades retratado por Aristófanes em Rãs ( 102 I-1022), como uma peça que o sopro

$$
37 \text { H. D. F. Kitto, Greek Tragedy (London 1939) } 52 .
$$


de Ares percorre com uma potência maior. Desde a primeira palavra que a presença do inimigo é perceptível às portas de Tebas e que o som da guerra não deixa ilusões sobre a proximidade do ataque. Mas essa primeira palavra é dada à defesa (I-38), a um Etéocles no papel do general que, na hora suprema, dirige aos seus homens uma alocução decisiva ${ }^{38}$. A famosa metáfora da 'nau de estado' proporciona a imagem poeticamente falante da situação: como um navio sacudido pelo furor da tempestade, Tebas agitada por ventos de guerra depende, para impedir o naufrágio, do seu piloto que, com mão firme, segura o leme. Ao lado da protecção divina, ou mesmo para alguns acima dela, é determinante a aç̧ão humana e sobretudo a capacidade daquele que, porque comanda, é responsável pelo destino geral. Embora correndo o risco de impiedade para com a intervenção divina, pela confiança talvez excessiva que deposita na reacção humana, Etéocles é o militar decidido e responsável perante os homens que comanda e a cidade que defende. Antes da hora de pegar em armas, a sorte da guerra decide-se por palavras, e estas são um factor determinante na luta. Em primeiro lugar as palavras justas criam, entre os defensores ameaçados, o clima propício de coragem e de determinação adequado a uma vitória; porque, além do mais, comunicam estratégias e transmitem ordens eficazes à condução de um processo de defesa; mas sobretudo porque, na leitura dos Sete, possuem um poder ominoso, capaz de atrair vantagem ou insucesso, e por isso o seu uso rigoroso é, mais do que as próprias armas, condição de um resultado. Inteligência e determinação são, neste monólogo de abertura, os traços de um chefe totalmente destacado, sob uma luz mais forte, dos homens que comanda e individualmente responsável pelo curso dos acontecimentos imediatos. Mas a palavra disciplina é apropriada ao tom geral desta rhesis, onde ordens peremptórias e racionais se sucedem, seguidas sem dúvida por uma pronta e incontroversa obediência. Etéocles não é só um utilizador competente da palavra certa, mas um homem de acção precisa, reflectida e oportuna. A entrada imediata de um mensageiro (40-68) com informações colhidas, por incumbência do rei, no terreno inimigo sobre as condições do ataque é disso mesmo a confirmação. Etéocles não omite um pormenor, está atento a tudo, joga na antecipação sem descurar as exigências do momento. Esta é a primeira janela aberta sobre o inimigo exterior, para permitir perceber a iminência do ataque e

38 O. Taplin, Stagecraft, 129-130, defende para esta cena de abertura a presença de figurantes silenciosos, que corporizem os destinatários do discurso de Etéocles. 
a violência radical dos objectivos do invasor: vitória ou morte. Mas a reaç̧ão de Etéocles a estas notícias iniciais (69-77) relembra aquilo que o público de Ésquilo sabia desde o primeiro momento, porque a versão conhecida do mito assim o estabelecia e porque os Sete contra Tebas são a terceira peça de uma trilogia, antecedida de Laio e Édipo, para nós perdidas: ao invocar os deuses da pátria e a Maldição paterna, o filho de Édipo expunha com evidência o sentido profundo deste conflito, que, mais do que uma simples invasão de um qualquer conquistador ambicioso, é uma guerra dirigida pela maldição de um pai contra os seus dois filhos. Este conflito, que parecia confrontar um invasor externo com um defensor interior, em dois campos distintos, é afinal um combate civil ou mesmo familiar, porque os interesses em litígio são os de dois irmãos. Com este apelo à maldição, a personalidade do comandante exibe a sua segunda face, a do homem condenado pelo destino.

Para além da reacção masculina, obediente e submissa às suas ordens, Etéocles tem de enfrentar também a atitude feminina, que é simbolicamente a da população civil, mais dependente e mais desprotegida porque não armada. Diante da emoção exaltada das mulheres, o comandante reage com uma irritabilidade desconhecida no homem racional que o prólogo se empenhou em retratar (vide supra Coros de mulheres). Assim completado o perfil de Etéocles, o defensor de Tebas e o filho de Édipo, a peça inicia o processo efectivo de resistência ao inimigo.

embate inicial tem por alvo o invasor externo. De novo em presença de um mensageiro e de notícias mais precisas vindas do campo inimigo, Etéocles estabelece os pormenores de uma estratégia de defesa, que é também a antecipação óbvia de um resultado. É esta a famosa cena dos sete pares de discursos, em que à simetria dramática corresponde o aperfeiçoamento das linhas de força de uma mente guerreira ${ }^{39}$.

39 É conhecido o debate gerado em torno do que é de facto o sentido da intervenção de Etéocles nesta cena. Já antes, em 282-286, depois do contencioso com o coro feminino, o monarca se ausentara na intenção de distribuir pelas sete portas de Tebas um guerreiro defensor, em cujo número ele próprio se encontrava incluído. Será então que Etéocles, perante notícias agora mais exactas trazidas pelo arauto, se limita a confirmar a distribuição já feita, que o foi então por mero acaso? Esta leitura deixa a tyche, que dirigiu um sorteio dos atacantes para cada porta (369-37I), a condução suprema e exclusiva dos acontecimentos. Mas talvez não seja esta a interpretação única ou mesmo a mais conforme com o pensamento de Ésquilo, porque deixa o seu herói inerte nas mãos do destino. Muitos comentadores da peça assinalaram já a ambiguidade no uso dos tempos verbais perceptível na cena dos escudos, como se uma parte das ordens de 
Etéocles é colocado diante de sete enigmas, a descrição individualizada dos atacantes de cada uma das sete portas de Tebas, informado da sua origem, armas e propósitos confessados em palavras de ameaça. Para cada um compete-lhe encontrar a interpretação correcta, que é também a capacidade de neutralizar, por palavras primeiro e por uma defesa militar adequada depois, o potencial inimigo. Etéocles é, na eficácia da resistência que determina para os seis primeiros atacantes, o homem racional, frio, inteligente e responsável que a peça vinha até então a valorizar. Mas a revelação adiada de que, na sétima porta, estará Polinices, ou seja, a Maldição, apela à outra face da sua qualidade de ser humano, a do homem fadado por um mau destino. Neste momento é a emotividade latente de Etéocles, que se evidenciara já no confronto com o coro de mulheres, que se impõe. $\bigcirc$ filho de Édipo reage com uma compreensível exaltação, sem abdicar no entanto da clarividência que lhe é natural. Sem mais hesitações reconhece que é chegada a hora do cumprimento de uma maldição, sem que, no entanto, o envolvimento pessoal que a situação extrema comporta Ihe permita a mesma racionalidade, total e ilesa, que aplicara em todo o raciocínio anterior. Etéocles está colocado diante do dilema decisivo que se coloca ao defensor de Tebas: quem designar como opositor de Polinices e como campeão num duelo arbitrado pela maldição (672-675)? $\bigcirc$ ataque contra Tebas ganhava neste momento o seu sentido pleno, o de uma guerra de defesa contra um inimigo que não é apenas exterior, mas o de uma ameaça íntima, profunda, visceral, porque opõe, no atacante e no defensor, o mesmo sangue que é o da casa real de Tebas, amaldiçoado pelos deuses e pelo destino.

Etéocles fosse a repetição do já determinado, e outra novas opções face às informações agora recebidas. Parece-me que, de entre todas as ambiguidades produzidas pelo texto, é importante salvaguardar a intervenção de Etéocles nesta distribuição e o seu ajustamento exacto às características de cada opositor. Assim o filho de Édipo recupera as suas qualidades pessoais de inteligência, determinação e de estratégia, como também uma participação activa e responsável no seu destino. Se o que ele antes tiver feito, fora de cena, tiver sido simplesmente uma selecção de guerreiros mais valentes sem uma decisão sobre a porta a destinar a cada um, o seu raciocínio estratégico actual ganha outro brilho. Dos seus campeões, Etéocles vai agora enviando cada um para a porta respectiva de acordo com o adversário anunciado pelo arauto. Guiado por critérios de lucidez e de competência, o homem maldito estará a dar também a sua colaboração ao destino, porque a lógica da distribuição mais adequada funcionará igualmente para a sétima porta; o duelo que aí ocorre é decidido por Etéocles, por razões de uma estratégia coerente, embora coincida com aquilo que o destino tinha já antes determinado. Sobre este assunto, vide O. Taplin, Stagecraft, |43-|46, | 52- 156. 
Ao espectador de Ésquilo a decisão de Etéocles coloca também um eterno dilema sobre que sentimentos o demovem: 'Certo do valor destes princípios, eu próprio irei fazer-lhe frente. Que outro seria para tal mais qualificado? Rei contra rei, irmão contra irmão, inimigo contra inimigo, serei eu a travar esse combate'. Uma raiva surda e uma exaltação irracional que convertem o comandante de Tebas num louco fratricida e a personalidade esquiliana num paradoxo ${ }^{40}$ ? Ou tão somente a mesma lucidez de sempre e uma racionalidade que, depois de um momento humano de exaltação, se impõe de novo? Um segundo debate com o coro, simétrico daquele que opusera a frieza do general ao pavor emotivo das mulheres na iminência do ataque, ocorre (677 sqq.). As Tebanas assumem desde logo a sua interpretação do dilema, que é a sua leitura da decisão do filho de Édipo (677-678): 'Não, meu querido amigo, filho de Édipo, não te tornes, nessa tua cólera, igual a esse homem que pronuncia palavras criminosas'. Admitem que é a cólera que comanda a sua determinação e colocam acima de tudo um crime de fratricídio que julgam estritamente necessário evitar. Mas estarão certas? Haverá de facto nas palavras de Etéocles o tom da emoção tresloucada? Ou não será exactamente o sentimento contrário, o da sensatez, a conduzi-lo? Sem dúvida que a guerra que se enfrenta é criminosa e o confronto entre os dois irmãos aberrante; mas a maldição que pesa sobre os filhos de Édipo permite adiamentos ou subterfúgios? Não será insensato procurar evitar ou adiar a decisão do destino? A todos os argumentos usados pelas mulheres, Etéocles responde com a sobriedade de palavras decisivas e lúcidas (719): 'Aos males que os deuses nos enviam não se escapa'. Depois de um breve lampejo de emoção - porque, embora superior, Etéocles não deixa de ser uma criatura humana -, o senhor de Tebas parece reintegrar-se na sua personalidade verdadeira: frio, racional, sensato e corajoso, Etéocles caminha para o combate contra seu irmão Polinices. Conquista, por todas as qualidades que possui, a palma da vitória (792-802): Tebas está finalmente salva, o sol brilha sobre ela depois da tempestade. Como bem nota A. Burnett ${ }^{41}$, Ésquilo poupa-nos a todos os pormenores deste duelo; ao contrário de uma imagem viva de violência e de barbaridade, própria de um destruidor, como a de Tróia arrasada

40 É abundante a bibliografia sobre esta famosa questão; cf., e. g, A. Burnett, 'Curse and dream in Aeschylus' Septem', GRBS 14 (1973) 343-368.

41 Op. cit., 346. 
por Agamémnon, não há em Sete nenhuma referência a ódio, nem à ferocidade ou brutalidade dos golpes com que na sétima porta os dois guerreiros se abateram. Tão somente o resultado importa, transmitido com a sobriedade e dignidade que merece um episódio onde, acima de quaisquer outras forças ou sentimentos, ponderou a vontade indiscutível do destino. Tal como outrora seu pai diante da Esfinge matadora ganhara pela inteligência a libertação de Tebas, também àgora Etéocles fazia reviver igual destino: diante de uma nova maldição a ameaçar a cidade, o rei voltava a fazer uma escolha certa, colocando toda a sua perspicácia ao serviço de uma leitura correcta das leis que comandam o destino dos homens: 'Aos males que os deuses enviam ninguém escapa'.

Pelasgo assume também, em Suplicantes, o papel do monarca compelido a defender-se de um invasor, em nome da sagrada regra da hospitalidade. Não se trata portanto de uma luta em que questões pessoais ou directamente relacionadas com Argos estejam em causa, mas de uma situação comum a outras peças $^{42} \mathrm{em}$ que o auxilio a refugiados em perigo traz sobre quem os socorre uma terrível ameaça de guerra. Entre as razões que levam os fugitivos a procurar auxilio junto de um monarca ou de um povo específicos está, naturalmente, o poder e a capacidade de protecção efectiva que se lhes reconhece, para além do respeito pela humanidade que se julga poder fazer valer na sua presença. Este é um quadro que exige força e riqueza da parte de um grande senhor, vantagens essas colocadas ao serviço do bem e do interesse público, ao contrário do que acontece com o conquistador. Dessas qualidades advém para quem as possui um prestígio especial, em função do cumprimento de regras de filantropia, que vão além do simples disponibilizar de bens que com abundância se possui. $O$ acolhimento dado comporta risco, porque obriga o hospedeiro a partilhar com o perseguido a violência do perseguidor. $\bigcirc$ que começa por ser uma questão de foro social ganha entretanto um nítido contorno político.

Ésquilo cuida da imagem de apresentação de Pelasgo (| 80-|85). Vista à distância a sua aproximação, Dânao pode descrevê-la como 'uma nuvem de poeira, mensageira muda de um exército' (180). Logo the chega aos ouvidos 0 ruído dos eixos e das siringes e já de longe se vislumbram os escudos e os dardos, por entre cavalos e carros de guerra. Este é um quadro de poder, que não se limita a sugerir apenas um efeito teatral, mas garante que, na hora do perigo, o rei argivo terá meios de disponibilizar uma protecção eficaz às

42 Vide supra 18-21. 
suplicantes. $\bigcirc$. Taplin ${ }^{43}$ traz à discussão se o corpo de guarda pelasgo, com cavalos e carros, é simplesmente descrito ou posteriormente mostrado em cena. Tendo em consideração a capacidade descritiva tantas vezes demonstrada por Ésquilo, a par da sobriedade perceptível no seu teatro, é admissível que apenas uma sugestão desse aparato bélico fosse mostrada, cabendo ao texto a descrição mais circunstanciada da sua magnificência. Mais tarde (492-503), alguns homens desse mesmo corpo de guarda são chamados a acompanhar e a proteger Dânao nos seus primeiros passos dentro de Argos, à procura de uma acomodação protectora e conveniente para as Danaides. Assim acompanhado, Dânao antecipava uma imagem do futuro senhor de Argos, função que viria a assumir na segunda peça da trilogia, Egípcios ${ }^{44}$.

Apesar de o espectáculo do potencial militar ser um factor importante na caracterização de um monarca destacado, o apelo das Danaides e o anúncio da aproximação do inimigo irá denunciar a sua inutilidade, quando a guerra se manifesta não como um mero confronto de forças mas um embate de princípios. Antes de pôr em marcha homens e armas, o rei tem de se valer da perspicácia e da lucidez para defender o seu povo. Sobre ele afinal pesam duas ameaças: a de um perseguidor humano, os filhos de Egipto, contra quem os recursos bélicos podem ser úteis, se a sua decisão for o acolhimento das Danaides; afastar este perigo e recusar protecção aos perseguidos significa ofender Zeus Xenios e atrair sobre Argos um perigo sem defesa, a ira divina. Depois de uma longa e difícil ponderação, Pelasgo faz a única escolha possível, a de defrontar um adversário humano à sua altura, ainda que violento e perigoso.

Um rei que assume riscos para a sua pátria e que comanda uma defesa tem sempre por trás de si, próxima e viva, a vontade do seu povo. De uma forma ou de outra a interferência dos cidadãos na acção é clara, ou como guerreiros subordinados às ordens do seu chefe, ou como população civil directamente afectada pelos resultados do confronto. Por isso, a voz do povo é permanente em todo o episódio e não apenas, como no caso dos conquistadores, perante o resultado final. Pelasgo, para quem o grande dilema é assumir a necessidade de uma invasão do seu território, consulta os Argivos desde o primeiro momento. Norteado por princípios de partilha do poder, o rei suspende qualquer decisão

43 Stagecraft, 200-202.

44 São frequentes os momentos na peça em que uma avaliação do poder de Pelasgo é mencionada: quando o monarca se apresenta às Danaides (250-270); e quando o inimigo se vislumbra já no horizonte (739-740, 746-747). 
até ouvir a vontade do seu povo (368-369, 398-399). Não sem que, como calorosamente the é lembrado (370-375), ele seja de facto, na qualidade de monarca, o verdadeiro responsável pelo que de terrível a decisão comporta.

Junto do seu povo, Etéocles usava de autoridade e de disciplina, quando se tratava da organização da resistência; ou de alguma violência e irritabilidade quando se impunha calar a exaltação desanimadora das mulheres. A iminência da luta justificava medidas peremptórias e imediatas. Pelasgo, ainda retido pela necessidade de uma decisão que poderá justificar um ataque ou evitá-lo, opta pela persuasão ${ }^{45}$ e mostra saber usar, para com o povo, as palavras certas (529, 615,623 sq.). Em vez de ordens determinadas ou de censuras vigorosas, o rei de Argos prefere sugerir ao seu povo a necessidade de uma escolha semelhante àquela que a sua mente preferiu também (480-486): depor os ramos de súplica por todos os altares da cidade ajudará a criar uma captatio beneuolentiae, que justifique a preferência do rei e estimule o apoio geral. Ultrapassada a difícil escolha, Pelasgo comanda desde logo os que o rodeiam: Dânao, para que auxilie nos preparativos da captação da opinião pública; os seus homens, para que o acompanhem e protejam; e as próprias Danaides sobre o comportamento adequado a adoptar.

Apesar da autoridade e eficiência que evidencia nos preparativos, como na determinação com que defronta o arauto inimigo, Pelasgo não é premiado com o sucesso. É mais ou menos consensual entre os estudiosos da trilogia ${ }^{46}$ que a batalha que o final de Suplicantes anunciava veio a ocorrer de facto; nela os Argivos foram vencidos e Pelasgo morto, apesar do alto preço a que o perigo de impiedade foi evitado.

\section{A mulher no poder}

Como vimos já, a figura da soberana em Ésquilo ganha projecção quando a aç̧ão assenta na ausência do rei. Nesse contexto, a intervenção feminina tem

45 R. P. Winnington - Ingram, 'The Danaid trilogy of Aeschylus', JHS 8I (196I) 148-I49, entende que a visibilidade deste motivo da consulta popular e da adesão da vontade do povo à do soberano produz consequências débeis em Suplicantes. Daí conclui que o tema eventualmente ganhava relevo no desenvolvimento da trilogia, talvez na terceira tragédia, Danaides, em que o rei, Dânao, vinha a ser rejeitado por decisão popular.

46 Vide Winnington-Ingram, op. cit., 142. 
relevo e a sua autoridade pública justificação. Nas tragédias conservadas onde esta situação existe - Persas, Agamémnon e Coéforas -, as rainhas detêm um poder equivalente ao dos monarcas e sobressaem, de forma diversa em cada circunstância, como um elemento da autoridade feminina em contraste com a masculina. Elas são, nesse caso, um interlocutor inevitável do coro, também ele procurador da autoridade ou dos interesses régios, como um espelho do próprio soberano. Pela sua natureza e pelo papel responsável que são chamadas a exercer, as soberanas abarcam ainda, na sua feminilidade, a representação da sociedade civil, aquela que não integra o exército, mas que, na retaguarda, se mantém na expectativa e sofre com agudeza os resultados penosos dos perigos que a ausência do rei ou o desfecho de uma campanha no exterior comportam. O papel dramático que desempenham é, em todos estes contextos, muito forte. Por fim, para além da actuação pública que a sua situação permite ou mesmo exige, estas personagens femininas são dotadas de um lado pessoal, onde dominam sentimentos ou reacções humanos; vemo-las agir não apenas como rainhas, mas como esposas e mães; o conflito de emoções que as aflige reveste todo um leque de variantes, desde uma dedicação e lealdade absolutas que fazem delas as guardiãs firmes dos interesses masculinos; até à raiva e ao ódio perante agravos de que se sentem vítimas e que as transformam em inimigas ou rivais do poder másculo, ocultando sob um exterior de fidelidade a arma mortal do ódio.

Atossa é, na perspectiva das peças conservadas, o primeiro exemplo de uma soberana actuante na preservação dos interesses instituídos da corte oriental. Nos Persas, Ésquilo reserva-lhe dois grandes momentos de intervenção, em uníssono com o próprio desenvolvimento geral da tragédia. $\mathrm{Na}$ sua primeira aparição (150-|58), a rainha dá uma imagem concreta da grandeza da sua corte, em riqueza e poder, embora seja também porta-voz das apreensões que, pela voz dos conselheiros, se vinham já a adensar sobre Susa. Tal como um rei na plenitude da sua autoridade, ela entra sobre um carro previsivelmente acompanhada de um séquito, num aparato de gala real coincidente com o brilho do ouro e com a pujança de um enorme exército, que corporizam o fausto persa. A autoridade régia, que a tradição e o nomos oriental lhe conferem, para além do prestígio pessoal, justificam as atitudes de reverência que a sua presença provoca. À condição régia, no oriente, é reconhecido um ascendente incontestável e de proveniência divina; logo é como um raio de resplendor imortal que a mãe do grande rei é saudada por 
uma corte que se prostra a seus pés. Palavras de saudação associam-se ao gesto, numa homenagem expressa a tudo o que constitui o contorno, cultural e teatral, de Atossa (I55- | 57): 'Excelsa senhora das mulheres persas de cintura profunda, velha mãe de Xerxes, esposa de Dario! Partilhaste com um deus dos Persas o leito, e de outro deus te tornaste progenitora'.

É como mulher persa e consorte real que a rainha actua. Com o seu povo partilha todas as preocupações pelo destino dos ausentes: como rainha, pela segurança e sucesso dos Persas; como mãe, pela sobrevivência do seu filho, o general ao comando de todos os outros filhos da nação. Atossa comunga e acentua as apreensões já manifestadas pela clarividência política dos conselheiros; mas a sua emoção tem outras raízes; o que lhe falta em conhecimento administrativo ou estratégico, sobra-lhe em percepção e sensibilidade. Os sinais de que Atossa dispõe não resultam de uma avaliação consciente do poder relativo das hostes em conflito. $\bigcirc$ que ela comunica é a mensagem do transcendente, o aviso que vem do além sob forma de sonhos e presságios, com que os deuses confirmam as suspeitas humanas. É patente a sensatez com que a rainha exprime os seus temores e incontornável a evidência dos sinais do desastre que transmite. Ninguém duvida, nem mesmo a prudência e a respeitabilidade dos velhos do coro, da justeza das suas preocupações. Acima de todos os temores, no entanto, a rainha coloca o que Ihe causa a ausência da autoridade masculina; a realeza e o poder são vulneráveis na falta do soberano (165-169), do mesmo modo que um rei despojado das riquezas que possui perde legitimidade.Trono e soberano fazem, no conjunto, uma imagem de força inseparável, porque 'o olho da casa é a presença do seu senhor'. Nesta perspectiva, a autoridade máscula é insubstituível, só ela garante segurança e futuro a uma sociedade. Com esta afirmação, Atossa assume claramente a posição que é a da cultura que representa: como mulher, não compete com o ascendente masculino nem com o poder institucional do rei.

Neste primeiro encontro público com o coro, a rainha não faz mais do que transmitir preocupações e sinais divinos, sem ousar qualquer iniciativa. Só por conselho dos velhos ela toma parte na acção $(215-225,229-230)$ dentro do que são os seus atributos, encarregando-se das preces e dos rituais propiciatórios. Ainda que muito digna na sua intervenção, Atossa não tem nem reivindica outra autoridade que não seja a que the cabe como consorte e mãe dos dois últimos monarcas da Pérsia. Depois de ouvir a narrativa do arauto, 
grata porque lhe garante a sobrevivência de Xerxes (299), mas penosa porque descreve a chacina de que todo um exército foi vítima, Atossa retira-se para enfim cumprir a sua missão junto da divindade.

Mas Ésquilo proporciona-lhe uma segunda entrada (598-622), que, como reverso da anterior, colabora com o novo momento que se vive na peça, aquele em que a desgraça se confirmou e o regresso do vencido está iminente. Todo o aparato régio que marcou a primeira aparição de Atossa se apaga; a rainha que agora entra em cena vem a pé, sem fausto nem séquito, dobrada à realidade de um destino que quis aplicar à prosperidade persa um revés profundo. Da Atossa anterior resiste a prudência e a dignidade, que são armas desta rainha na prosperidade e na desgraça. A apreensão que a afligia tornou-se pavor pelo futuro de um povo atingido por um duro golpe. É este o estado de espírito com que a soberana conduz o ritual, que dirige aos mortos com dedicação sincera; rigorosa nas oferendas e nas preces, ela espera do velho Dario a resposta clara e tranquilizadora. Neste convívio dos vivos com os mortos, Atossa desempenha o papel privilegiado de interlocutora do monarca falecido, a quem a liga uma fidelidade inquebrável e a partilha de uma preocupação pelo filho de ambos e pelo seu povo. Antes de regressar ao além, é desta vez Dario quem incumbe Atossa de uma missão de elevada importância: a de revestir o Xerxes esfarrapado em trajos condignos, o mesmo é dizer, a de reintegrar um rei fragilizado na consideração do seu povo e no exercício pleno do seu poder. Em termos gerais, Atossa é um símbolo de resistência, na medida em que sobreviveu ao marido ao lado de uma nova figura régia, fazendo a coesão de uma linhagem no exercício da sua qualidade de mulher; e é evidente, no seu comportamento, a capacidade de ultrapassar o desastre, assegurando um fluir entre passado e futuro que são também os do povo a que pertence.

Embora as circunstâncias que rodeiam a experiência de Clitemnestra na corte de Argos sejam, em certa medida, semelhantes às de Atossa - como soberana regente na ausência do monarca, que chefia uma campanha grandiosa e arriscada -, a sua natureza e actuação segue um padrão completamente diverso. À irmã de Helena, o autor da Oresteia dá um outro vigor de sentimentos e de intervenção, que faz dela uma personagem de primeiro plano na peça.

Não nos surpreende, portanto, que a partir dos primeiros versos do Agamémnon, o público seja levado a formar uma imagem da rainha de Argos, ainda antes de a poder avaliar em presença. É breve, mas muito expressivo, o esboço que o Vigia dá de Clitemnestra no seu monólogo inicial ( I0- I I): antes 
de qualquer outra referência, a acção que melhor caracteriza esta soberana é que 'domina' e esse exercício pesado da autoridade é próprio da natureza, de certa forma deturpada e excessiva, de 'uma mulher máscula, de espírito ansioso'. Nestas poucas mas pertinentes palavras, o carácter de Clitemnestra fica patente: ainda que mulher, ela usa, na ausência do marido, de uma prepotência abusiva e imprópria do seu estatuto e que, também por isso, ameaça a normal reassumpção das funções pelo seu legítimo detentor. Nesta mulher máscula existe latente uma rivalidade com as prerrogativas masculinas que só aguarda um estímulo para se revelar. A fidelidade, a que não é isenta a submissão, é incompatível com a atitude natural da filha de Tíndaro, que não preserva intacto o poder de outrem, mas actua dentro de interesses, ainda pouco definidos, mas evidentes aos olhos de todos (18-19). Porque se o Vigia se refere a Clitemnestra de acordo com a sua interpretação de homem simples, o retrato que produz coincide sem desvios com aquele que fica patente das palavras dos velhos do coro na saudação à rainha (258-260): 'Venho prestar homenagem, Clitemnestra, ao teu poder. Porque é correcto manifestar respeito à esposa de um monarca, quando se encontra vazio o trono do marido'.

Tal como Atossa, Clitemnestra vem trazer novas à expectativa do coro. A sua aparição é desprovida do aparato régio que cercava a soberana de Susa; as galas do carro, Ésquilo preserva-as desta vez para o vencedor. Clitemnestra ganha, com a naturalidade despojada mas activa da sua vinda, o tom de uma autoridade, pública e doméstica, que dirige com eficiência os preparativos da recepção do herói. E como se de uma vaga correcção da sequência dos Persas se tratasse, em Argos os sonhos são suspeitos (274-275) e é em elementos que parecem mais objectivos que se acredita. Pelo menos à superfície, a luz concreta de um facho é entendida como um testemunho mais credível do que um sonho. Mas, na verdade, esta outra rainha, mais determinada e segura de si, rejeita a subjectividade do transcendente como fraqueza ou infantilidade. Diante dos velhos cidadãos, ela antecipa a previsão dos acontecimentos em Tróia, os trâmites do combate, a vantagem, quem sabe se cruel, dos Gregos. Com esta avaliação, Clitemnestra subverte a sua posição de soberana em relação aos anciãos; ela não os interroga sobre Tróia, como antes Atossa sobre Atenas; ela sabe, tão bem ou melhor do que eles, a realidade da guerra.

E exactamente porque o seu ascendente político e régio é patente e dominador, um véu se rasga para desvendar a hipocrisia de Clitemnestra, que resume o seu diagnóstico como 'ideias de uma simples mulher' (348), 
procurando mostrar uma fragilidade feminina tão pouco conveniente ao seu comportamento. $O$ coro reconhece-lhe competência, mas não se ilude com as suas palavras de modéstia, recordando com oportunidade aquela centelha máscula, indisfarçável no seu carácter (35I): 'Mulher, são de um homem sensato essas tuas palavras de prudência'.

A segunda entrada em cena de Clitemnestra, depois que o arauto confirmou a vitória apesar do custo elevado que representou também para o vencedor, tem, em relação à de Atossa, um movimento inverso. A viúva de Dario regressava acabrunhada pela derrota do seu povo, para executar ritos de lamento e luto; Clitemnestra regressa com maiores razões de júbilo, para executar cerimoniais de acção de graças (587-6I4). A euforia que extravasa é exuberante e excessiva, alheia a uma louvável discrição. À luz da vitória respondeu com um grito, que parece ecoar aquele brado guerreiro que os Atridas lançaram na hora da partida. Da opinião pública, esse exibicionismo da rainha colhe censuras por parecer o produto de uma certa histeria ou precipitação bem femininas. Neste seu regresso ao convívio público, Clitemnestra limita-se a um solilóquio, toda entregue a uma euforia íntima, isolada da solidariedade com os que a cercam, todos eles súbditos de um só rei. A mulher de Agamémnon faz da vitória argiva uma causa sua, e ocupa-se por inteiro com a recepção ao rei e ao marido. As notícias que o arauto comunicou na sua ausência apenas ao coro não a interessam (598-599), prefere ouvi-las da boca do próprio Agamémnon. Os pormenores da guerra passam assim para o círculo conjugal e, de soberana, Clitemnestra reduz-se agora à condição de esposa: a que festeja o regresso do marido, que comanda a recepção, que the franqueia as portas da casa, que lhe garante, com protestos de uma fidelidade absoluta, a guarda do lar. O empenho na afirmação da virtude conjugal parece exagerado e a despropósito, como a própria reconhece; a necessidade de 0 afirmar torna-se, por isso mesmo, suspeita, também porque diversas insinuações nos foram já feitas sobre a escandalosa perturbação do palácio (36-39, 6I5-6 |6). Clitemnestra faz um jogo de falsidade para ocultar, na exibição do feminino, a ousadia máscula dos seus verdadeiros desígnios.

Perante a atitude mais individualista de Clitemnestra, é natural que a sua próxima presença diante do público aconteça com a chegada de Agamémnon, o rei vencedor e o marido há tanto tempo ausente (855 sqq.). Esta sua aparição reveste algum aparato, todo aquele que ela destina ao acolhimento do recémchegado. Caracteriza-a uma certa ousadia nas palavras que pronuncia em 
público: protestos de amor para com o marido, sob o efeito de uma exaltação que é verdadeira e falsa ao mesmo tempo. Ninguém duvida, de facto, do seu prazer em ver chegar o objecto dos seus anseios, quaisquer que sejam os motivos dessa alegria. Como também são verdadeiros os seus lamentos de mulher, durante longos anos privada do marido e do homem, o que condenou a sua feminilidade a uma tremenda frustração (86|-862). A que extremos a não conduziram as notícias contraditórias, que lhe anunciavam ora morte ora salvação, e que acrescentavam uma tremenda dúvida a uma já de si penosa solidão. Por trás de uma reacção e de um comportamento que simbolizam o padrão geral, Clitemnestra resguarda por enquanto as particularidades do seu sentir. Fala do exilio, por prudência, do herdeiro do trono, ameaçado de traição na ausência do pai. Para concluir pela exaustão de uma dor que, dia e noite, Ihe manteve o coração em sobressalto. A exaltação que agora manifesta é, por isso, oportuna e apropriada, ainda que expressa naquele tom excessivo que não abandona a filha de Tíndaro. $\bigcirc$ próprio Agamémnon o regista e justifica com o exagero criado pelo afastamento e pelas emoções da guerra (9|4-9|5).

Ultrapassadas as aflições da ausência, Clitemnestra fala da cerimónia do triunfo, que é parte já do seu plano. A entrada do palácio está sob seu controle. Para consumar o desejo de penetrar no palácio, o vencedor de Tróia tem de The aceder à vontade (905-9/3). Por meio de protestos de amor, ela realmente domina e atrai a uma cilada a sua vítima. Simbolicamente estende-lhe em frente um caminho de púrpura, que o é de homenagem e de traição a uma só vez (vide A imagem do poder). Com argumentos capciosos, cala-lhe as reservas e vence o seu próprio combate, dominando o rei, o marido e o homem.

Com a revelação do destino de Agamémnon, revelam-se também os secretos desígnios de Clitemnestra. Uma prece ambígua com que a rainha remata a recepção ao vencedor suscita, em simultâneo com as suspeitas por todos aludidas, uma expectativa mais premente (973-974): 'Zeus, Zeus, senhor do bom fim, concede um bom fim à minha oração. Actua sobre aquilo a que te cabe pôr um fim'. Depois de Zeus protector dos hóspedes e senhor da clarividência e da luz, é como senhor de um bom fim que a rainha o evoca. Em todas as almas se instala a expectativa.

Clitemnestra retorna mais uma vez para chamar Cassandra, a cativa favorita do marido, que aguarda ainda em silêncio sobre o carro. Agravada pela presença ofensiva da rival, que Agamémnon levianamente Ihe recomendara, a senhora de Argos põe de lado fingimentos e patenteia a raiva que the vai na 
alma. A Cassandra ela procura também dominar pela autoridade e pela frieza ( 035 sqq.), para ser desta vez vencida pelo silêncio obstinado da Troiana. Subtilmente, a tentativa frustrada do ardil feminino sobre a cativa contrasta com a recepção dada ao herói. À submissão da sua primeira vítima responde a lucidez da segunda, que se reserva o direito de uma superior liberdade: a de aderir ao destino com independência e por vontade própria. Diante de Cassandra, Clitemnestra sai derrotada; não porque the falte a inteligência e a subtileza de sempre, mas porque a profetisa detém, como dádiva dos deuses, uma visão superior e distante do seu destino e responde com clarividência ao desafio ditado pela paixão da rainha de Argos.

Está aberto o caminho para o desfecho ansiado por Clitemnestra. Um espaço de visão abre-se para além da porta cerrada do palácio por obra dos olhos inspirados de Cassandra (I I25- I | 29). Num quadro expresso em termos selvagens de um combate travado entre a vaca e o touro possante, a vidente antevê a cilada que dobra sem resistência, no enleio de uma rede, a superioridade do macho. Ao mesmo tempo, Clitemnestra elimina, de forma ignóbil, o guerreiro, que escapou vivo ao combate glorioso para cair indefeso, dentro das paredes do lar, às mãos de uma mulher. À morte soma-se o opróbrio que inflige aos ideais masculinos uma tremenda desonra. Sem encontrar reacção, a fêmea desfere o golpe e degola a sua vítima nas profundezas humilhantes de uma banheira. A mulher máscula vence um inimigo indefeso, servindo-se de uma argúcia que the confere ao braço uma força desconhecida. Para além dos actos, a jovem inspirada por Apolo percebe-lhe também os sentimentos (I23|-1238). O diagnóstico que faz do acto é o próprio retrato da rainha de Argos: a fêmea que assassina o macho é um padrão contra natura, uma criatura desumana que encontra só nos monstros modelos adequados. No seu percurso de vida como mulher, cada experiência veio ferida de estranheza: como mãe privada de uma filha é dominada pela raiva e pelo ressentimento que impõe violência; como esposa, o que ela sente é ódio, contra o marido que a privou injustamente dos seus direitos de mãe, contra o guerreiro que colheu as coroas de um triunfo, ou simplesmente contra o estatuto masculino e as suas prerrogativas. $O$ prazer com que ela vence o vencedor é demasiado para lhe caber dentro da alma, explode num grito de vitória perante a derrota do adversário, aquele mesmo que soltara também o seu brado de vitória na partida das hostes para Tróia e o repetira na hora de arrasar o inimigo. Os gritos reúnem numa mesma barbárie estes vencedores, concorrentes por um triunfo final. Um outro motivo move Clitemnestra, secundário apesar de tudo, que 
Cassandra invoca depois e já fora do verdadeiro núcleo do conflito, a tensão entre marido e mulher, macho e fêmea, dentro do lar. $\bigcirc$ adultério é um elemento perturbador, ainda que secundário, nesta relação (1258-1263). Clitemnestra,'a leoa que dormia com o lobo na ausência do leão', junta à sua vingança novos motivos. O sentimento não tem lugar nestas paixões, que são fogosas mas simplesmente carnais. Sobre o marido, a mulher infiel acrescenta mais um golpe, para cobrar a traição de alguém que também ela já traiu, mas que ofende o seu orgulho no regresso ao lar acompanhado de uma favorita.

O que o público acompanha através das previsões de Cassandra poderá ainda verificá-lo num tremendo espectáculo que o poeta lhe reserva para 0 final. Pela porta do palácio que se abre para desvendar as atrocidades cometidas no interior, sai um quadro de vingança. Abatidos, manchados de sangue, jazem os dois cadáveres, o do conquistador da cidadela de Príamo e 0 da cativa troiana. Poderosa, dominando como sempre a cena, ergue-se por trás deles a fúria assassina, uma Clitemnestra firme, brandindo na mão a arma do crime $^{47}$. A longa rhesis que então pronuncia tem a mesma crueza do gesto e traz até nós a revelação total de uma alma dominada pelo ódio. Alegrias, subterfúgios, carícias com que a senhora de Argos disfarçava de normalidade a sua natureza de monstro chegaram ao fim. Foram úteis para a execução deliberada da vingança, mas desabam face à consumação total do projecto. A determinação máscula que a domina não dá lugar a arrependimentos ou recuos. Clitemnestra está entusiasmada pela fúria e entrega-se ao prazer do acto consumado. A mesma determinação que sempre a pôs ao comando das situações prevalece nesta hora. Ela recorda, com um gozo infinito, cada golpe, cada estratégia, cada cedência indefesa da sua vítima; a rede que enleia Agamémnon, o tecido faustoso, uma moldura de grandeza a envolver a nudez simples de um cadáver, os gemidos ténues como única reacção do poder do herói. Algumas gotas de sangue da vítima condecoram ainda o braço que a feriu. Esta é tão só a imagem exterior, a dos actos palpáveis que exprimem a vontade de uma alma que não tem pejo em se revelar. Perante a surpresa do coro, mais atingido pela deturpação da natureza de uma mulher que mata o marido do que pela perda de um rei, Clitemnestra analisa os estímulos íntimos

47 Sobre qual a arma usada por Clitemnestra na execução do crime, espada ou machado, vide M. Davies, 'Aeschylus' Clytemnestra: sword or axe', CQ 37 (1987) 65-75; A. H. Sommerstein, 'Again Clytaimestra's weapon', CQ 39 (1989) 296-30 I; A. J. W. Prag, 'Clytemnestra's weapon yet once more', CQ 4 I (199I) 242-246. 
que ditaram a violência do golpe. $O$ sacrifício de Ifigénia foi a chave que soltou os ventos de uma cólera infinita, a de uma mãe frustrada dos seus direitos de progenitora e de guardiã da família, em favor de interesses masculinos, os da execução a qualquer preço de uma campanha ousada. Do executor de outrora, Clitemnestra faz aos deuses da vingança um outro sacrifício, que apazigue uma dívida em aberto. Esta é a dimensão de uma justiça que ultrapassa os motivos de uma mãe para ascender à satisfação dos superiores desígnios dos deuses. Ao cumprimento de uma exigência divina, Clitemnestra acrescenta o prazer da sua própria desforra, a de uma esposa traída que limpa no sangue do marido adúltero e da sua predilecta um terrível ciúme feminino. A esposa agressiva que é Clitemnestra tira do domínio da situação um prazer especial: é ela quem prepara aos apaixonados o seu último encontro de amor, no próprio palácio, sob o tecto conjugal, onde a imprudência de Agamémnon cometeu um último desafio ao orgulho insuspeitado de uma mulher: é ela quem os reúne num mesmo leito, sem resistência, para sempre ligados num quadro de morte.

Depois do distúrbio empolgado da vitória e da consumação de um anseio, a filha de Tíndaro como que começa a ceder à hostilidade que a cerca. As censuras e acusações dos velhos, apenas as primeiras vozes argivas que a hostilizam, começam a romper a barreira protectora do seu orgulho e a impor o temor ao ódio. Ao invocar a maldição a pesar sobre a casa dos Pelópidas como inspiradora do seu acto (|475-| 480), a assassina esbate os seus motivos pessoais, aqueles que constituem o seu móbil e a razão primeira do crime, por trás de uma vontade superior que lhe conduz a mão como punição legítima de um culpado. $O$ monstro agressivo e sequioso de sangue, agora satisfeito, recua para dar lugar à mulher que teme, consciente enfim do excesso do acto cometido (1497-1504): 'Tu imaginas que este acto é meu. Mas nem mesmo penses que eu sou a esposa de Agamémnon. Sob o simulacro da mulher deste cadáver é o antigo, o terrível génio de Atreu, desse cruel anfitrião, que cobrou a sua vítima, imolando um guerreiro para vingar os filhos'.

Pela reaç̧ão do coro, cada espectador é chamado a assumir para o futuro de Argos um outro rumo (I560-I566). É inegável que Clitemnestra cobrou, com outro ultraje, um ultraje. Com o seu acto, uma espécie de pena de talião ressuscitou na casa dos Pelópidas, e com os seus argumentos uma outra lei, que sujeita a condição humana, ganha agora legitimidade. Se diante da iminência da chacina de Tróia e do sacrifício ímpio de Ifigénia os velhos tinham invocado o Zeus da clarividência, guardião da lei superior de 'aprender pelo sofrimento', 
perante $\circ$ acto de vingança que esclarece, em toda a sua extensão, os resultados da escolha de Agamémnon, outro desafio é colocado a um ser humano, a Clitemnestra, a rainha vingativa: 'Ao culpado o castigo'. Com o enunciado desta regra, de que também Zeus é o preservador, um novo ciclo se inicia no destino de Argos e dos seus soberanos.

Clitemnestra reentra no palácio coberta de sangue, mas detentora por inteiro da autoridade régia de Argos. A seu lado no trono está Egisto, 'tu e eu' à frente dos destinos de uma cidade que experimenta uma crise renovada $\mathrm{e}$ ameaçadora (1672-1673). Mesmo se mais conciliadora, a mulher, que se confronta com a revolta de um povo que chora o seu rei assassinado de uma forma vil, não abdica de um sonho que alimentou e que parece agora poder realizar-se: o de ocupar o lugar que a autoridade masculina deixou vago. $A$ seu lado Egisto é simplesmente a encarnação de uma fragilidade quase feminina ( | 625-1626), que não concorre com a mulher máscula, apenas serve de súbdito predilecto à sua supremacia absoluta.

O futuro de Argos vivido nas Coéforas não dá ao projecto de Clitemnestra a viabilização que ela sonhara. A eterna regra 'ao culpado o castigo' tem de cumprir-se para que a legitimidade das leis divinas prossiga incólume. Mesmo se investida no poder e responsável por um regime onde o temor reina, a segurança da rainha mostra desde logo debilidades e rupturas. A ameaça que se aproxima está evidente na presença de um Orestes, que chega incumbido da missão confessa de vingador (18-19), ao mesmo tempo que um sonho temível exige de Clitemnestra sacrifícios (22-23). A viúva de Agamémnon está, de certa forma, numa posição que relembra a de Atossa: privada do marido, o rei falecido, e na expectativa do regresso de um filho, o legítimo herdeiro do trono. Sob esta superfície semelhante, os dados das duas situações são no entanto opostos: Atossa tem do seu lado a fidelidade e dedicação com que se posiciona face ao poder instituído de Susa, expresso nas pessoas do seu marido e filho; o papel que ocupa na corte é profundamente feminino, como modelo de expectativa pelo regresso do guerreiro e pelo desejo de ver normalizada a sociedade persa no reencontro do trono e do seu ocupante legítimo. Atossa é portanto a mulher respeitada, que actua como garantia de normalidade futura para a sua casa e para o seu filho. Clitemnestra porém encarna a traição; a sua presença no poder foi conquistada pela violência, depois de excluído o seu detentor no momento de apogeu e de glória; a preservação dessa mesma autoridade alimenta-a Clitemnestra à custa do afastamento criminoso do seu 
herdeiro e de uma vaga protecção do seu amante. Por isso a ambas as soberanas, a persa e a argiva, o destino reserva um futuro contraditório.

É através de um sonho que ambas reconhecem a vinda próxima do filho ausente, sonho a que respondem com sacrifícios junto do túmulo dos maridos. Mas os temores que as agitam são diversos: Atossa, convicta de um mau desfecho para uma campanha de que o seu filho é o responsável, deseja obter da sabedoria do velho rei a cura para a crise iminente, que aflige não apenas uma mãe mas todo um povo. Clitemnestra teme por si e por um poder que detém contra a justiça, de que as suas vítimas reclamam compensação (Coéforas 32-42). E não podemos deixar de avaliar a mudança que se operou na soberana desde aquele dia em que recusava os sonhos como fantasias inaceitáveis para acreditar apenas em sinais concretos. Com a perda da segurança que o crime trouxe à sua vida, Clitemnestra passou a cultivar um pavor que a tornou susceptível e, por isso, também mais feminina. $O$ diálogo directo com os mortos está-lhe vedado por força do crime cometido; e as vozes que no ritual a representam, das mulheres do coro e de Electra, dão à prece recomendada, de apaziguamento, um outro tom, o da vingança. Deuses e mortais erguem à sua volta vozes de reprovação. Abatida, a nova Clitemnestra pouco tem a ver com a mulher poderosa de outro tempo. Instalada num trono que todos contestam, a sua autoridade desabou. Um relâmpago de falsidade recorda ainda a mulher que foi. Perante o mensageiro que lhe traz a falsa notícia da morte de Orestes - o próprio Orestes -, a senhora de Argos exibe ainda a sua face de anfitriã. Orestes quer falar com o senhor da casa e é ela que avança a recebê-lo e a oferecer-Ihe o banho da hospitalidade. Sete anos antes a mesma recepção tinha sido dada ao pai, na hora exacta em que o golpe fatal se preparava. Com a oferta de um acolhimento amigável, Clitemnestra revolvia fundo as iras do vingador, o seu próprio filho. Já a notícia da morte de Egisto abalava o palácio, quando, à procura da sua própria clarividência, ela se interrogava no momento exacto do castigo (Coéforas 887-890): 'É pelo dolo que vamos perecer como matámos. (...) Saibamos enfim se somos vencedores ou vencidos'.

\section{Figuras menores}

Apesar de o teatro de Ésquilo ser sobretudo um exemplo de grandes situações ou problemáticas, onde a caracterização individual das figuras é 
secundarizada, a verdade é que nele existem, como vimos, personagens de recorte inesquecível. E mesmo para além dos agentes de primeiro plano na acção, há exemplos de intervenientes menores, de presença fugaz, mas que apesar disso constituem criações primorosas e também, à sua maneira, marcantes. Deste grupo distinguiremos duas, o Vigia do Agamémnon, e a Ama de Orestes das Coéforas.

\section{OVigia}

A personagem solitária, que ocupa a cena no início da peça numa atitude de expectativa, à espera de que algo por que há muito espera aconteça, é um processo eficaz na tragédia e na comédia. Eurípides proporcionou deste motivo quadros inesquecíveis como os que ofereciam Helena e Andrómeda na cena de abertura. Recordemos também de passagem exemplos conhecidos de Aristófanes - Diceópolis, em Acarnenses, Lisístrata na peça que usa o seu nome, e Praxágora em Mulheres na assembleia. Em qualquer um destes exemplos, a figura em questão é o protagonista da peça, a ocorrência por que espera dizIhe directamente respeito, e aos interesses que representa, e a ausência dos restantes que aguarda adia o desencadear de uma acção prevista e urgente. A cena ganha, por sua intervenção, desde o momento inicial, um suspense nítido, que envolve o público na expectativa de saber o que justifica a impaciência da personagem. Para si próprio ou para um confidente imaginário (como Eco no caso de Andrómeda ou a lamparina no de Praxágora), o sujeito vai rememorando os motivos do estado de espírito que o domina. Para além das palavras, os gestos podem contribuir para dar vida ao retrato de sentimentos vários, sofrimento, medo, indignação, cansaço, reclamação, mas sobretudo de uma certa impaciência pelo que tarda em acontecer depois de uma longa espera. Uma rhesis é o meio natural para complementar e esclarecer pela palavra as raízes de tanta agitação. Neste contexto empenhado, o monólogo de abertura ganha vigor e a informação que transmite a força de um esclarecimento necessário e urgente. Quando esta cena termina, a longa expectativa da personagem será satisfeita com a chegada dos seus parceiros, para que finalmente a acção por que espera aconteça. E com esta satisfação se dá início à intriga. Trata-se portanto de um momento de teatro particularmente eficaz, onde a força psicológica da personagem e o seu envolvimento pessoal 
dão cor e dinâmica a um momento dramático cujo objectivo essencial é informar o público sobre as condições iniciais da acção.

Em boa parte este é também o papel do Vigia no Agamémnon. Não se trata de um protagonista, mas de uma personagem secundária, cuja intervenção se esgota com este momento e cuja identidade é perfeitamente marginal. Mas, mesmo vestindo a pele de um simples servo, esteVigia desempenha com muita eficácia o papel que compete ao tipo de personagem que representa. Sozinho em cena, numa angústia que o passar do tempo foi adensando, continua à espera de uma notícia que é também a vinda do senhor da casa ausente na guerra. A sua presença no local onde espera não resultou da sua iniciativa pessoal, mas do cumprimento de uma ordem; como também os motivos que a justificam não são seus, mas dos seus senhores. E apesar de todos estes factores de distanciamento, o Vigia é dotado de uma força extraordinária, que transmite com o vigor e a frontalidade que a sua condição de homem inculto, espontâneo e primário nas suas reacções justifica.

A exploração verbal, feita pela personagem, das circunstâncias envolventes não permite que o público perca um só dos pormenores que constituem as linhas de força do quadro (Agamémnon 1-7). Para confidente do seu desespero, o servo tem os deuses a quem suplica o fim de uma longa espera; com esta invocação à única presença solidária em tanto isolamento, o Vigia coloca o poder divino à frente de uma peça onde dele depende a determinação efectiva de um longo caminho a percorrer pela personagem central. A insistência na ideia de tempo justifica um estado de espírito, para que igualmente contribuem as circunstâncias do local em que a personagem se encontra. A noite ou a madrugada oferece um cenário propício a este tipo de situação, onde o isolamento, a excitação, a impaciência pelo que há-de acontecer são condimentos naturais. Do movimento dos astros que conhece na evolução que acompanha o passar das estações, o servo extrai a ideia da eternização do tempo, de uma solidão que só a natureza testemunha longe do convívio dos outros homens. Um apontamento de cenário dá também um contributo decisivo ${ }^{48}$ para a caracterização visual do momento. Como Vigia que durante a noite prossegue a sua missão, o servo mantém-se insone sobre o único leito

48 Lembremos o túmulo no caso da Helena euripidiana, o rochedo de suplício onde Andrómeda se encontra prisioneira, o assento na Pnix no caso do cidadão Diceópolis, um canto de rua nos de Lisístrata e Praxágora. 
que the está acessível, o telhado do palácio real. Como um cão de guarda, agachado no seu posto de observação, o homem é a imagem da persistência e da lealdade, a que o rigor da missão não poupa mesmo assim palavras de profunda melancolia. Do tempo geral que cerca a sua experiência, a personagem passa ao tempo actual (8-10), que é ainda de espera por um sinal de luz que brilhe na escuridão e traga a vitória. Não é por demais encarecer a simbologia discreta que esta luz, juntamente com a menção dos deuses, traz a uma trilogia que é um conflito permanente de trevas e luz a caminho de um esclarecimento que só os deuses permitem. Nela se acumulam sugestões fundamentais para todo o desenvolvimento posterior: um sinal palpável da clarificação que se procura, de vitória, de regresso, de promessa de felicidade e paz, de missão cumprida; mas esta mensagem depende de um symbolon (8), de um sinal que se envia como mensageiro sem palavras, e que é o testemunho de uma relação ambígua entre verdade e aparência.

Da moldura que o rodeia, a atenção inflecte para o homem em si (12-19). A solidão em que se encontra vem carregada de sofrimento: distante do calor da casa e do convívio dos homens, ele sofre a agressão da natureza no orvalho que o enregela; em vez do sono, a sorte condenou-o à vigilia constante, assaltada de temores e de angústias, a que nenhum repouso dá tréguas. Gestos e atitudes anunciam a reaç̧ão de um homem contra as circunstâncias adversas que lhe são impostas: cantos e murmúrios preenchem o tempo de uma longa espera, adiando as lágrimas e os soluços que a consciência de uma realidade difícil provoca. Das profundezas da memória sobrevêm os fantasmas que o atormentam: a ausência do senhor, a autoridade temível de uma mulher de vontade máscula, a desordem surda que reina na casa. Atormentado por todas as apreensões que a solidão, a noite, o tempo aumentam, o Vigia oscila entre a dor e a esperança, num ciclo de tortura interminável.

É então que se faz luz (22-39) e o nosso homem explode em júbilo. Em cena, a imobilidade dá lugar à exuberância do movimento. Com o entusiasmo espontâneo das almas simples e o alívio incontido que dá o termo de uma expectativa, o criado exulta. Grita, salta, dança e brada da distância a boa nova, para que todos enfim se associem em festa ao quebrar da sua solidão e sofrimento. A lealdade que o tempo não quebrou conhece agora o prazer da saudação ao herói que regressa. Mas num último fluir de luz e sombras, o Vigia termina em trevas, depois que o facho brilhou; o silêncio pesa-lhe sobre a língua para Ihe calar o júbilo, - mesmo silêncio que paralisa um palácio, um e outro testemunhas de 
acontecimentos que todos quereriam esquecer e eliminar. Assim se some o Vigia na intimidade da casa, atingida por uma luz insuficiente para dar um brilho pleno aos seus cantos escuros. Cumprida a missão de tantos anos, o servo abandonanos repartidos entre os aplausos ao vencedor que chega e a apreensão que um palácio sombrio representa, na hora em que a Oresteia vai realmente começar.

\section{A Ama de Orestes}

Esta figura feminina tem, em Coéforas, uma intervenção particularmente expressiva. A sua vinda a cena resulta de uma ordem que secundariza o seu papel ou interesse directo na acção que executa. Das suas implicações ela nada sabe em concreto, limita-se a julgá-las na aparência, sem uma lucidez que the permita a leitura profunda do que elas ocultam. A sua passagem pela cena restringe-se a um discurso, seguido de um breve diálogo com o coro. E apesar de tão reduzida a sua actuação, esta Ama é uma figura de um recorte notável e de uma importância dramática relevante.

A Ama é uma personagem a que a tragédia grega nos habituou, sobretudo pela mão de Eurípides, que fez das Amas de Medeia e de Fedra figuras inesquecíveis do seu teatro. Em Ésquilo, nas tragédias que conservamos, a Ama de Orestes é uma personagem isolada. São características destas mulheres a idade, que significa um envolvimento pessoal de muitos anos com os senhores da casa. Particularmente ligadas à senhora, estas servas são solidárias com cada momento da vida da familia e leoninas na sua dedicação. Em geral são dotadas de espontaneidade e de uma sabedoria popular muito básica, uma e outra inimigas de fingimento e de sofisticação. Por isso agem levadas pelas melhores intenções, mas contribuindo, sem mesmo disso se darem conta, para o desencadear dos reveses do destino sobre a casa que servem. A Ama de Orestes partilha da maior parte destes traços, redimensionada no entanto a sua relação com Clitemnestra. Para com a sua senhora ela não funciona como exemplo de serva dedicada e solidária, mas como contraponto naquilo que as torna realmente rivais: a experiência maternal. A actuação de Cilissa em Coéforas (731-782) separa o momento em que 0 vingador definiu uma estratégia de actuação daquele em que executa as suas vítimas. É-lhe dado, por ordem de Clitemnestra, o papel insuspeitado de colaborar no golpe convocando Egisto para o palácio onde o aguardam notícias de Orestes. Numa aparição inesperada 
fora do palácio, ela é a imagem de uma angústia, que não compreende mas que a destrói. Sem hesitação, a mulher revela todo o seu sentir com uma espontaneidade desordenada, que salta do momento actual para o passado e que é um quadro completo dos momentos essenciais da sua vida. As suas primeiras palavras são a repetição das ordens da senhora, que sem discussão ela se apressa a cumprir. Mas não o faz por uma devoção cega ou por uma adesão incontestada; ela denuncia, sob o ar sombrio com que a rainha transmitiu uma ordem na hora de crise, o lampejo de um sorriso, que os olhos da senhora de Argos não conseguiram esconder: sob uma dor fingida, Clitemnestra exultava. As notícias que chegavam culminavam a injustiça e coroavam de sucesso a traição dos usurpadores. Mas o palácio, ou seja, a cidade e o seu povo rendiamse à derrota e à ruína. E é deste lado que esta mulher honesta se encontra, logo oposta, como cidadã, à autoridade pesada e ilegítima dos seus senhores. Ela é, ao lado do coro, a voz da reclamação cívica. Mas o envolvimento próprio à Ama de Orestes na sorte da casa real de Argos é sobretudo pessoal. É como ama, uma espécie de mãe, que ela mais se opõe a Clitemnestra, porque mais dedicada do que a própria mãe. A rainha foi, nas suas palavras, apenas a progenitora, porque mal nascido foi nos seus cuidados que o filho de Agamémnon encontrou o calor materno. À distância, a velha Ama recorda ainda cada momento da sua maternidade: as noites perdidas, os trabalhos constantes, a obediência aos caprichos de uma criança, os pequenos cuidados do dia a dia, as fraldas, a fome, a sede, as necessidades primárias que exigem tarefas pequenas e mesquinhas. Mas é sobre elas que se constrói um vínculo inquebrável, que une mãe e filho. Essa foi uma função que Clitemnestra delegou, limitando-se a uma maternidade meramente fisiológica e sem afecto. Por isso, a notícia da morte de Orestes a deixa fria, ou até intimamente satisfeita com a eliminação de um concorrente, o herdeiro do poder de Argos.

Sem sequer o imaginar, Cilissa dava à condenação de Clitemnestra e ao castigo iminente uma legitimidade decisiva. A dedicação própria de uma mãe enche-lhe o coração, mas centra-se no objecto do seu carinho, a criança, o que, no caso deturpado da familia real argiva, se repercute na divergência com a mãe. Na sua simplicidade honesta, esta mulher é o negativo de Clitemnestra, que lança uma luz esclarecedora sobre as culpas da rainha. Insensivelmente somos levados a reavaliar a actuação de Clitemnestra não só como mãe de Orestes, mas também aquela reivindicação da vingança do sacrifício de Ifigénia que a rainha exigia como agravo supremo infligido por Agamémnon aos seus direitos de mãe. Será que 
Clitemnestra nutria por Ifigénia um sentimento maternal que não concedia a Orestes? Ou simplesmente Ifigénia era o pretexto seguro para contestar as prerrogativas masculinas na casa e na sociedade e não passava do móbil que faltava ao seu desafio de uma autoridade insustentável? Por interferência da Ama, o tom geral da primeira parte das Coéforas muda radicalmente para um nível pessoal, primário e humano. A maternidade e o que ela significa ganha, pela mão de Cilissa, o tom que lhe faltava, íntimo e inconfundível, na sua natureza humana e feminina.

\section{Os bárbaros}

Ésquilo viveu de uma forma directa o grande conflito bélico que opôs, em princípio do séc. $\vee$ a. C., os mundos oriental e helénico. Da vitória de Maratona colheu, como combatente, uma inesquecível coroa de vitória, e com os seus compatriotas deixou-se envolver pela euforia e pelo alívio que se seguiram às batalhas salvadoras de Salamina e Plateias. Todo o perigo que as pretensões imperialistas da Pérsia representaram para a pátria grega, como aquela indizivel experiência de vitória e de liberdade conquistada ao fim de vinte anos de guerra afectaram o homem que era Ésquilo, como os contemporâneos que constituíram o seu público, e fizeram da cena esquiliana um campo de empatia patriótica. Mas para além de colher o sabor de uma guerra favorável numa peça que por inteiro Ihe dedicou - os Persas -, Ésquilo participou com atenção no despertar do mundo helénico para a existência de um outro universo, situado fora das suas fronteiras, cuja presença a guerra tornara mais sensível. Para além de inimigo, o bárbaro manifestou-se como um elemento humano marcado pela diferença, de língua, de paisagem, de aparência física e de costumes, sempre disponível para um confronto revelador com o mundo grego e para uma avaliação relativa. A par do temor desconhecido e da ameaça que a guerra revelou, os Gregos passaram a olhar com mais curiosidade e atenção para o espaço não grego, a conhecê-lo e a retratá-lo e a assumir diante dele uma opinião e um sentir que a historiografia grega do séc. $V$ obrigou a aprofundar e a corrigir. Mas com Ésquilo acompanhamos um tempo de profunda mudança nesta questão fundamental para o pensamento da época: a dicotomia grego / bárbaro 49.

49 Através dos títulos conservados de tragédias perdidas de Ésquilo, H. Bacon (Barbarians in Greek tragedy, 8) identifica em 34 a presença segura de cenário ou de personagens estrangeiras. 
De entre as tragédias conservadas há duas que decorrem em cenário não grego, os Persas e o Prometeu. Compete portanto ao poeta mobilizar todos os meios ao seu dispor para obter desta circunstância o efeito desejado. Conscientes por um lado da nossa ignorância sobre os hábitos e os recursos de cena da tragédia mais antiga, mas convictos da simplicidade que caracteriza os elementos materiais da cena no tempo de Ésquilo, vamos deixar-nos orientar pela ideia de que ao texto cabe dar aos limites do cenário um contributo decisivo. Assim o contexto visual que enquadra a acção resultará de uma colaboração entre texto e elementos materiais do cenário onde ao primeiro cabe uma responsabilidade maior. A aproximação dos dois exemplos acima referidos coloca de imediato à nossa consideração uma evidência; na leitura do mundo bárbaro, o Grego do séc. $\checkmark$ está consciente de profundas diferenças, que lhe permitem hierarquizar os bárbaros ${ }^{50}$, caracterizá-los nos seus traços por oposição ao Grego e entre si, de modo a estabelecer os diversos estádios civilizacionais a que uma mesma época histórica assiste. Numa perspectiva de conjunto, os Persas representam um potencial inigualável de poder financeiro e militar, um contexto civilizacional diferente mas elevado, que se distingue dos Gregos por aspectos vários no plano político, cultural, social e económico, com certeza, mas se destaca também de todos os outros bárbaros. Por seu lado a Cítia, que serve de cenário ao castigo de Prometeu, é um exemplo de barbárie extrema, remota em relação ao mundo habitado, agreste e enorme, desabrida e hostil, onde a humanidade se sente ainda distante das grandes conquistas da civilização.

A acção dos Persas decorre na capital persa, a cidade de Susa, de que o texto se empenha, desde os primeiros versos, em acentuar o fausto e o brilho dourado. É o ouro a principal insígnia da morada régia,'este palácio de opulência e de ouro' (3-4), como o exército potente (9), que constituem as bases fundamentais da sua autoridade imperialista. No texto, a proliferação de composições adjectivas com o elemento poly- dá força poética a esta realidade. Do ouro, a descrição desliza naturalmente para a valorização da quantidade e do número como critérios essenciais na avaliação do poder.Todos os principais testemunhos gregos que contribuem para a caracterização do oriente nesta época - Heródoto entre os mais destacados - confluem nesta mesma noção

50 Atossa sugere explicitamente esta hierarquização, ou pelo menos o xadrez de povos que constituem o império sob domínio persa, nos w. 762-763, destacando dos Persas todos os outros bárbaros. 
de que a quantificação é o factor essencial da avaliação do seu poderio. Norteados por esta mentalidade, os velhos conselheiros tranquilizam vagas angústias pelo destino do exército em campanha com a contabilização, que parece sugerir-lhes segurança e ascendente. Uma primeira imagem, de traços globais, recorda a mobilização completa de toda a força bélica oriental ( | | - |2), antes de se passar a uma discriminação que fragmente esta mole imensa (16 sqq.). São então enumerados os contingentes, de dimensão imponente, de pujança aparatosa, armados com um equipamento que constitui a sua marca de origem e lhes define uma estratégia militar própria. O catálogo que ocupa o párodo harmoniza, com a opulência de Susa, a das cidades suas aliadas. Os contributos militares são, sem excepção, desmesurados e bem equipados, com a participação condigna de cidades onde o ouro igualmente abunda ('Sardes, a cidade do ouro', 45; tal como Babilónia, 52-53). Alguns traços de pormenor retocam o retrato de contingentes concretos, trazendo à enumeração o efeito expressivo e identificador dos epítetos. A modalidade das armas que preferem, o arco nomeadamente, fazem desta a imagem específica de um exército asiático (é este um elemento caracterizador de uma hoste não grega, como mais à frente se confirma, 146- I48); são archeiros os Persas (26), como o são também alguns dos seus chefes em particular (30), e os Assírios (55). A delicadeza oriental dos Lídios (4I) traz ao quadro de guerra a fragilidade requebrada dos povos asiáticos, que contrasta com o contexto guerreiro em que participam, bem como com a masculinidade militar que daria a vitória aos Gregos neste conflito. Mais impressionantes e audíveis do que os epítetos são os nomes - antropónimos, etnónimos e topónimos -, que enumerados em longas listas contribuem de forma eficaz para o efeito de número e de quantidade, mas sobretudo de exótico e de estranho, que caracteriza esta enorme massa humana em movimento. À sua frente segue o monarca, que constitui a coroa simbólica do que é o povo que comanda: senhor único e monocrático de um enorme império, que na rota da sua história anexou muitas outras forças asiáticas sob sua autoridade, é-lhe reconhecido um ascendente que lhe advém da origem e das prerrogativas divinas, 'o filho da chuva de ouro, mortal semelhante aos deuses' (79-80). Rodeado de um exército de insígnias orientais - a lança e o arco -, o monarca desfila sobre um carro sírio (84-86), que the convém como moldura adequada a um poder sobranceiro e vigoroso.

Depois do quadro do poder militar, o fluir da tragédia permite a imagem da opulência da corte fora do circuito específico da guerra. Da sociedade persa, 
na sua versão cívica e doméstica, é representante, para além dos velhos conselheiros, a personagem da rainha. A sua entrada permite a encenação da reverência e da etiqueta que cerca os soberanos orientais. Atossa vem num carro régio, seguida por um séquito, e a sua entrada exige a prostração cerimoniosa dos conselheiros (152-154). Em todo o aparato de que se cerca, ela é a digna senhora de uma mansão recamada de ouro (159), por cujo destino sente apreensão na ausência do monarca. A própria riqueza já excessiva de que a corte persa é detentora, se é motivo de orgulho e de apogeu, não deixa de ser também razão de temor pelo risco de uma decadência medida pela dimensão exagerada de um poder real (|6|-164).

Estabelecida a identidade do mundo oriental, a sua caracterização ganha um novo relevo por oposição ao contexto europeu, esse universo distante e menosprezado pelo asiático que o monarca guerreiro partiu a conquistar. A ignorância da rainha sobre a Grécia e o questionário com que pretende informar-se junto do coro dão, antes de mais, a noção concreta de um tempo de descoberta entre povos afastados que a guerra punha em contacto. Mas para além de um cotejo explícito entre os dois povos, importa salientar os critérios que ditam o raciocínio de Atossa e que são os traços essenciais na definição de um conceito de civilização e de cultura (230-244). A geografia relativa do lugar é o primeiro factor de avaliação, juntamente com a distância e a acessibilidade. $O$ poder militar que assegura a sobrevivência e a identidade própria e livre de cada comunidade vem a seguir. Para Atossa é também relevante a fortuna, que do seu ponto de vista assegura a estabilidade dos povos. Depois da potência militar de que a Grécia já deu provas, entramos no campo das divergências mais profundas. A Grécia tem alguma riqueza material, a que as minas de prata do Láurion lhe garantem, não com certeza a que a corte de Susa se orgulha de exibir. As armas que usa no combate - a espada e o escudo - distinguem-na pela própria estratégia bélica. Mas é na superioridade espiritual que reside a sua principal vantagem. Em vez de um chefe a cuja autoridade se dobrem, os Gregos adoptaram por seu único condutor a liberdade, que se mostrou capaz de infligir à chefia autocrática de Dario pesados reveses.

Este pano de fundo trazido à reflexão do público pelos testemunhos do coro e de Atossa foi sujeito a um teste de eficácia, em terra grega, de que todo o desenvolvimento dramático posterior irá revelar os resultados. A simetria dos elementos dramáticos é óbvia, a insistência em novos catálogos persistente. Mas em vez de um quadro de opulência e majestade, a reportagem que um 
mensageiro, o fantasma de Dario e o próprio Xerxes trazem à cena é a da ruína e da destruição. Ao palácio brilhante de ouro chegam notícias, cada vez mais concretas, de derrota. As longas enumerações de povos e de chefes repetem-se, não para fazerem um balanço de força e de ameaça bélica, mas para avaliar a dimensão imensa do fracasso. Foi trágico o resultado do encontro entre os dois povos que, na hora de medirem forças, se manifestaram por um brado, que bastou a opor as suas duas naturezas. Na descrição que o mensageiro faz da batalha de Salamina, os Gregos puseram-se em marcha ao som de um péan (393) e de um lema de liberdade (402-405): "Filhos da Grécia, libertem a vossa pátria, os vossos filhos e mulheres!'. Do lado persa apenas um rumor vago, indistinto, irracional thes respondeu (406-407). Neste simples confronto verbal estavam patentes as marcas das civilizações profundamente díspares que se enfrentavam. Mas já a luta se desencadeara e novos comportamentos vieram acentuar o fosso de distância entre os dois campos: a crueldade incivilizada com que o soberano persa promete liquidar os inimigos sobreviventes (37I), a sensação de terror que o canto grego infiltra nas linhas adversárias (39l), a incapacidade persa de prever e de aniquilar a finura estratégica do grego (355-368), e a fuga desesperada perante o sucesso inimigo $(374,422)$. Destes traços resulta o perfil do bárbaro cobarde, ingénuo, inferior em inteligência e profundamente selvagem. O poder económico e a força do número, o aparato do luxo ou a ordem forçada por uma hierarquização rígida desmoronavam-se sem recurso nesta prova suprema a que se viam sujeitos. Ao mesmo tempo que duas civilizações, assentes em critérios divergentes, conheceram a sua hora de confronto, onde uma realidade insuspeitada corrigiu o fulgor ilusório das aparências.

Outra imagem de um território bárbaro é dada pelo Prometeu. Em vez de uma civilização poderosa e requintada, as montanhas remotas da Cítia onde Prometeu é agrilhoado são distantes, inóspitas e desabitadas ( I-2, 2I).A própria natureza oferece uma face hostil, com os seus rochedos elevados e abruptos (4-5), onde os passos humanos não cruzam. O clima fustiga de forma impiedosa estas paisagens (15), situadas a norte, longe da doçura mediterrânica; às tempestades que as assolam sucedem-se os raios castigadores do sol. Este é o lugar que os deuses escolheram como punição para um dos seus iguais, exactamente porque a qualidade de vida que proporciona é, já de si, castigadora. Os confins da Cítia, esses rochedos que delimitam a fronteira do mundo (1 I7), são portanto o retrato da barbárie mais elementar, de onde o progresso e os avanços da civilização se mantêm arredios. 
Em torno deste lugar solitário existem no entanto tribos de povos que, a diversos pretextos, são trazidas à nossa imaginação e que constituem um universo diferente do europeu. Por efeito das menções que em circunstâncias várias thes são feitas, o mundo asiático vai ganhando espaço e identidade no extracénico. É primeiro o coro de Oceânides a mobilizá-lo, numa onda de solidariedade em torno de Prometeu (406-424). No seu apelo desfilam os povos da Ásia - Amazonas, Citas, Árabes -, caracterizados pela paisagem geográfica que habitam e pelos costumes e estratégias bélicas de que fazem uso. Estes são tópicos que os textos etnográficos da época, nomeadamente os de Heródoto, convencionalmente privilegiam.

A entrada de uma lo desvairada e errante, a única presença humana no desterro de Prometeu, permite a insistência nas características do lugar sobre que a cena abre. A estranheza do local e da raça que nele habita, patente nas interrogativas da princesa argiva, recorda este elemento essencial da dramaturgia do Prometeu (562 sqq.). Mas a errância de lo apenas cumpriu mais uma etapa, distante ainda de ver chegado o seu fim. É, no entanto, o prisioneiro da Cítia o profeta capaz de antecipar a sua continuação. Inspirado sem dúvida em informações semelhantes às expressas no Livro IV das Histórias de Heródoto, Ésquilo prossegue com uma rota que tem os extremos europeus por limite (707-735). Este é o espaço seguinte que os deuses impuseram a lo que percorresse; aquele que habitam os Citas nómadas, que vivem sobre carros e são archeiros conhecidos e arrojados (cf. Hdt. 4. 19, 46); depois os Cálibes, artistas do ferro; por fim as Amazonas (cf. Hdt. 4. I I0-1 I7), boas montadoras e inimigas dos homens. Este percurso é cheio de perigos para quem o atravessa, nele o desrespeito bárbaro pela vida humana faz lei. Para sua segurança 0 viajante que percorra estas rotas deve evitar os seus habitantes (Prometeu 7I2, 7I5), que são selvagens e sanguinários. A xenofobia é também sua característica, junta a uma terrível ferocidade (7|6). Até a paisagem parece partilhar a mesma ferocidade $(7|8,720-72|)$, de forma a tornar a marcha difícil ou mesmo impossível. As costas oferecem aos navios uma permanente ameaça de naufrágio e aos marinheiros a chacina (725-727). Com esta descrição, Prometeu prolonga a paisagem para além da solidão que o rodeia; noutros espaços que para lá se estendem vivem povos, mas a distância física e civilizacional a separá-los da Grécia é enorme. A agressividade que separa os dois mundos pressupõe do desconhecido uma ameaça latente e para o grego perdido nessas paragens um perigo incontornável. Nada do que constitui a 
cultura cívica dos Helenos aí existe: cidades, leis, rituais, organização familiar ou hospitalidade para com estranhos. As conquistas da civilização como os Gregos as concebiam contrastam com o vazio feroz da barbárie levada ao extremo.

Dos riscos que os povos concretos inspiram é fácil, por efeito da distância e do desconhecimento, caminhar, agora em terreno asiático, ao encontro de espaços mais remotos e nunca percorridos, que a imaginação povoa de monstros (788-8I5). Esse é o percurso do extremo oriente, onde habitam as Fórcides, monstros híbridos de um só olho e de um só dente (792-797), vizinhas das Górgonas, serpentes entrelaçadas à laia de cabeleiras (798-800), logo seguidas dos Grifos, de bico poderoso (Hdt. 4. 13) e dos Arimaspos de um só olho (Hdt. 4. 13, 27). De todos estes seres, os humanos só podem esperar animosidade e perigo, à medida de uma resistência digna de heróis. Só terminada esta rota de imprevistos, lo finalmente se encaminhará para o país dos povos negros, cortado pelo curso do Étiops, antes de conhecer as margens férteis do Nilo que lhe prometem redenção. Será em Canopo que lo vai conhecer repouso e dar origem a uma geração de cepa argiva.

Para além destas peças que decorrem em cenários estranhos, onde seres bárbaros e remotos se movimentam, há também aquelas outras tragédias em que estrangeiros pisam terreno grego, trazidos pelas condicionantes mais diversas e acolhidos de diferentes maneiras. A sua presença, de alguma forma surpreendente e susceptível de alguma curiosidade, justifica uma observação e comentários que são a denúncia dos factores de diferença. Na convenção do teatro grego - tragédia e comédia -, dois são os elementos que estabelecem a distinção essencial entre Gregos e Bárbaros: a aparência exterior, pela qual o trajo é em boa parte responsável, e a linguagem. Estes elementos, que propiciam na comédia uma exploração caricatural, são na tragédia sobretudo traços de caracterização que separam os diversos universos humanos em confronto.

É pela aparência exterior 'tão pouco grega' porque 'faustosa nos seus trajos bárbaros', que Pelasgo dá voz à sua surpresa perante um bando de mulheres estranhas que se refugiaram no seu reino de Argos (Suplicantes 234-236). E mesmo se o encontro entre o monarca e as suplicantes vai provar que existe entre todos um antigo vínculo de parentesco, a verdade é que o tempo e o afastamento geográfico que o destino impôs às descendentes de lo não deixa nelas qualquer marca que conduza a um possível reconhecimento. A roupa que usam nada tem a ver com o trajo tradicional da região ou da Grécia em geral (236-237). Pelo contrário, Pelasgo é capaz de perceber nelas traços de afinidade 
com o Egipto ou com a Líbia (279-28I). Na verdade as próprias Danaides ( I 19-120) tinham já antes caracterizado a particularidade do seu trajo como vestes de linho acompanhadas de véus fenícios. Mas a especulação de Pelasgo não se fica pelo simples aspecto do trajo que usam. $\bigcirc$ monarca especula sobre outros contornos da situação; afinal tem diante de si um grupo de mulheres em fuga, à primeira vista entregues a si próprias e sem protecção masculina, que ousam deslocar-se para longínquas paragens e fazer frente aos perigos da sua errância. Entre as cipriotas, as indianas ou as amazonas pode o monarca argivo encontrar modelos deste comportamento tão pouco feminino (282289), também ele estranho às atitudes que a sociedade grega associava à condição da mulher. Ultrapassada a barreira oferecida pelo aspecto exterior ou pela aparência superficial da situação em que se encontram, as refugiadas raciocinam e actuam com base em critérios de comportamento tipicamente gregos. Desde logo o padrão por que regem a súplica aos deuses e abordam a generosidade dos Argivos, traços essenciais da sua condição de suplicantes, são dessa mesma afinidade provas indesmentíveis.

Ainda que a linguagem incompreensível ou estropiada não sirva, na tragédia, como factor de comicidade, não deixa de se tirar dela algum efeito de caracterização marcante, também a este nível, da diferença. A consciência de que diferenças de vocabulário separam as diversas línguas pode ser assinalada pelo simples contraste na versão de uma palavra chave: o insecto que perseguiu lo tinha no Egipto, naturalmente, uma designação própria (308). Mas, seguindo o exemplo dos Persas ou do Prometeu, o poeta de Suplicantes insiste também nos topónimos e nos antropónimos (31 I-322, 547-555), que dão à narrativa de um contexto geográfico e cultural distante o toque mágico do desconhecido. É por essa via que as descendentes de lo reproduzem o universo onde a exilada grega se refugiou e onde deu origem a uma nova descendência de raiz argiva, em pleno país do Nilo. No caso das Suplicantes, Ésquilo vai mais longe no que respeita à caracterização de algumas figuras como não gregas; para além das próprias Danaides, a linguagem do arauto egípcio (825-902) é contrastante com a de todas as outras personagens. $O$ som bárbaro da linguagem das filhas de Dânao é por elas mesmas referido ( 118 sq., 128,972$)^{51}$, talvez como uma humilhação espontaneamente assumida no sentido de captar a boa vontade de

51 É de alguma forma vulgar em Ésquilo que o acento estrangeiro da linguagem de certas personagens seja valorizado por uma chamada de atenção das próprias ou de quem as escuta. 
um protector. Quanto à linguagem do arauto, marcada por alguma pobreza vocabular e pela insistência nos mesmos termos, vem permeada de palavras egípcias que conferem ao conjunto uma tonalidade imperfeita, estranha ou dissonante ao ouvido de um falante autóctone (cf. kárbanos, | | 8, 129, 9|4, bâris, $836,873,88$ I, palavras claramente estranhas ao grego).

Depois de reconhecer a identidade das estrangeiras e o seu vínculo de sangue com os Argivos, que legitima a súplica, é preciso integrá-las na comunidade grega. Apesar de descendentes de uma grega no exilio, o tempo e a convivência com novos hábitos fez das Danaides estrangeiras, cuja integração na comunidade helénica exige prudência e um cuidado minucioso. Dânao, que se revelara desde sempre a voz da sensatez na condução das pretensões das suplicantes e no protocolo a cumprir pela sua condição de fraqueza, é também agora a voz que dirige os cuidados a ter nos passos seguintes. A segurança em Argos exige uma protecção autóctone; para além da vontade de acolhimento manifestada, e no sentido de a viabilizar em concreto, Dânao pede uma escolta de Argivos, que serão guias qualificados num terreno desconhecido onde podem orientar os seus hóspedes na resolução dos problemas de acolhimento (492-496). Afinal, a simples circulação de estranhos nas ruas da cidade, sem uma credencial de aceitação que se traduz na presença protectora de algum cidadão, expõe o estrangeiro, imediatamente denunciado pelo aspecto e pelo contraste com os locais (496-498), a perigos e ameaças imprevisíveis. As próprias Danaides, quando mais tarde conduzidas por Pelasgo se dirigem ao centro hospitaleiro da cidade, fazem-se eco das recomendações de seu pai. É também para elas patente a animosidade que estranhos espontaneamente suscitam, sendo portanto a xenofobia por elas encarada como uma reaç̧ão humana natural. Por isso exigem a si próprias um comportamento discreto e sério, que não alimente reservas, mas pelo contrário suscite simpatia e tolerância (973-979).

Consuma-se, em cooperação hospitaleira, este primeiro confronto com estrangeiros em terra argiva. Mas fica também patente deste pacto de asilo que por ele há, para Argos, um preço a pagar sob forma do risco que representa um ataque dos perseguidores das Danaides, os Egípcios.

Já à distância Dânao percebe a presença dos inimigos egípcios. E mesmo se a visão que lhe é por enquanto acessível não permite distinguir mais do que linhas gerais, os perseguidores do país do Nilo são reconhecidos pela cor escura da pele em contraste com a brancura das túnicas (719-720). $\bigcirc$ tom 
queimado da pele era uma característica que aliás as próprias Danaides partilhavam e para a qual chamaram a nossa atenção logo após a sua chegada (70, 154-155). Incapazes de verem, do lugar em que se encontram, o quadro de desembarque nos seus pormenores concretos, as Danaides podem no entanto recordar a natural agressividade dos seus perseguidores e o desrespeito que thes é próprio diante dos deuses e dos códigos civilizados dos homens. De seguida, a presença e o ataque dos Egípcios sobre as Danaides será da veracidade desta acusação das vítimas a primeira prova (880 sqq.). Mas também Pelasgo irá confirmar que não há neste juízo das filhas de Dânao parcialidade ou um horror intuitivo que deturpe a sua avaliação. As palavras do monarca são duras na denúncia de uma violência tipicamente bárbara, em que os Egípcios parecem exceder-se (9|4). Não se trata, no quadro de invasão que - surpreende, de um simples ataque contra mulheres indefesas, num desrespeito total pelos deuses a cuja protecção elas se acolhem. Os atacantes desrespeitam também a autoridade local, desprezam os cidadãos argivos e o seu rei, invadem sem escrúpulo o território de uma cidade livre para nele cometerem atrocidades condenáveis (916-922). As regras do direito que devem reger o convívio entre os homens são-lhes estranhas. Para além dos seus nomoi desconhecem e rejeitam quaisquer outros. A única forma de negociar com outras comunidades que praticam é a violência e a ameaça.

Esta é a imagem do inimigo retratada na primeira peça da trilogia, quando se trata ainda de uma perseguição sobre as presas em fuga aos seus desejos. Mas a protecção dispensada por Argos às suplicantes, que impede a consumação da captura, produz uma segunda arremetida do invasor, que agora tem um objectivo acrescido: o de aniquilar e vingar a resistência de Pelasgo aos seus propósitos. Logo o motivo central da segunda peça da trilogia, Egípcios, corresponderia muito provavelmente a um regresso do invasor, desta vez reforçado por uma força militar, quer o momento do seu regresso correspondesse a um propósito de combate, ou à penetração de um território posterior a um combate bem sucedido; esta segunda hipótese tem a vantagem de resolver a concretização de uma luta que não pode ocorrer em cena. Mesmo se o título Egípcios parece anunciar a personalidade do coro, constituído pelos pretendentes das Danaides, há ainda assim a este propósito alguma discordância ${ }^{52}$. Uma hesitação possível entre singular e plural no título, 
Egipto ou Egiptos, pode fundamentar a teoria de que, no primeiro caso, o título designasse uma figura e não o coro. Mas de toda a maneira - e a minha opinião é claramente favorável à de um coro de Egípcios - esta segunda tragédia da trilogia alargava em cena a presença de estrangeiros. A vitória alcançada pelo invasor sobre os Argivos, por seu lado, tem potenciais de exprimir a violência bárbara e o perigo que ela representa para a segurança da Grécia. Violência injustificada e reprovável porque é posta ao serviço de uma causa também injusta. Centrada portanto sobre as consequências do cumprimento estrito da regra sagrada da hospitalidade, esta peça em que se consuma o domínio egípcio sobre Argos é ao mesmo tempo a consagração do desrespeito bárbaro por um código de comportamento civilizado.

Após a campanha desenvolvida à distância, em terreno bárbaro, Agamémnon traz de regresso à Grécia não só a experiência de uma luta contra povos desconhecidos, mas, entre os despojos de guerra, exibe vestígios humanos da identidade dos vencidos. Em Agamémnon, esse papel é encarnado na personagem de Cassandra; em Coéforas, no grupo de cativas que constituem o coro (75-76). De pé sobre o carro do vencedor, Cassandra é a imagem viva da conquista consumada no papel da escrava dobrada à vontade do seu senhor. E, no entanto, a jovem bárbara provém de um universo de riqueza e de luxo que Agamémnon recorda na hora de receber, como vencedor, a homenagem merecida. Perante a púrpura com que Clitemnestra cobre o solo para honrar - guerreiro, o senhor de Micenas protesta contra o luxo requintado próprio de bárbaros que a homenagem contém (919-921): 'Não me acolhas como a um bárbaro, de joelhos em terra e com gritos estridentes; não cubras o chão de tapetes para me preparar um caminho que desperta a inveja'.

Nada resta, porém, de todo este aparato de riqueza agora que Tróia se reduziu a cinzas. Do povo troiano que a povoou resta apenas uma sombra corporizada na cativa. $O$ chefe supremo dos Aqueus, antes de entrar no seu palácio, faz dela a apresentação breve que se impunha. Com a menção de 'a estrangeira' (950-95I), confirma todas as suspeitas já instaladas no espírito do auditório a partir do que tem de ser a caracterização externa desta personagem silenciosa até ao momento. Ela é, por seu lado, o prémio de honra do saque com que o exército distinguiu as prerrogativas do seu comandante (954-955).

A favorita estrangeira de Agamémnon Clitemnestra reserva um tratamento sobranceiro. Naturalmente a sua condição de rival justifica em parte 
o desprezo da rainha de Micenas. Mas outros pressupostos de inferioridade que - Grego tende a atribuir ao bárbaro estão explícitos na sua reacção. Cassandra terá o tratamento de uma escrava que deve obedecer à autoridade dos seus senhores, como é regra para os prisioneiros de guerra. Mas, na definição dos comportamentos futuros que Clitemnestra pretende estabelecer, surge a questão linguística a separar as duas interlocutoras. Porque Cassandra não se move, talvez não compreenda o grego em que a ordem lhe é dada (Agamémnon 1050-1052, 1060-1061), sugere a soberana com desprezo. Esta é a forma hábil por que, neste episódio fulcral na peça, Ésquilo deita mão à convenção que tradicionalmente separa o Grego do Bárbaro, a expressão linguística. Com esse traço elementar nesta distinção combina factores de natureza pessoal e psicológica, que interagem neste momento. A realidade é porém bem diferente; não só Cassandra conhece bem o grego (cf. I254), como é capaz, apesar de ser falante de uma outra língua, de contar a verdade em vários tons, ora subtis e enigmáticos, logo mais claros e precisos, sobre o palácio dos Atridas; cabe ao coro reconhecer-lhe essa competência (|200-| 20 |). Não Ihe falta portanto capacidade linguística nem visão profética, pelo que a sugestão do coro de que talvez um intérprete pudesse ser de utilidade no contacto entre Micenas e a sua nova habitante (1062-1063) se cobre agora de uma tremenda ironia. Irónico é também o registo feito pelos velhos argivos sobre o que thes parece ser o ar selvagem e indomável desta jovem, que reage à escravidão com a rebeldia de um animal acabado de capturar. Neste caso o coro é profeta; de facto Cassandra resiste às ordens mesquinhas e traiçoeiras de Clitemnestra, para ceder apenas, em liberdade, aos desígnios superiores do destino. Neste conflito entre as duas mulheres, a bárbara e a grega, o ascendente da princesa de Tróia tem uma dignidade esmagadora. 
Estratégias teatrais 
(Página deixada propositadamente em branco) 


\section{Sonho}

O motivo do sonho, de grande tradição na literatura grega anterior, tem no teatro de Ésquilo um lugar destacado. Ao lado das profecias e dos presságios, faz parte de um código de sinais que transmitem do além a vontade dos deuses ou do destino. São portanto uma mensagem sobre algo que vai afectar a vida dos homens, colectiva ou individualmente, com a imposição de uma verdadeira fatalidade. $\bigcirc$ sonho avisa sobre ocorrências iminentes e tem, por isso, no contexto teatral um duplo efeito: o de desencadear sobre quem o recebeu uma reacção emotiva e o de preparar o espectador para o desenvolvimento previsível da acção. A sua expressão dramática comporta sempre uma narrativa, a da visão tal como ela se revelou, com todos os factores de ambiguidade que Ihe são próprios, seguida de uma tentativa de interpretação. Este processo de análise desencadeia uma emoção de temor e de angústia, e aconselha uma reacção, que constitui uma tentativa votada ao fracasso, de o neutralizar. Tal significa que a atitude humana face à manifestação da vontade inabalável dos deuses não é de rendição e de inércia; o homem reage, procura actuar e, assim, conquista uma certa dignidade para a sua causa, mesmo se a vitória final lhe está invariavelmente vedada. Decerto porque a dinâmica do sonho exige sensibilidade aguda e pressupõe reacções emotivas, Ésquilo parece preferir as mulheres para agentes deste motivo. De facto, nas peças conservadas, são três as heroínas femininas que passam por esta experiência: Atossa nos Persas, lo no Prometeu e Clitemnestra nas Coéforas.

Pelo contexto em que ocorre, o sonho dramático é um elemento extracénico, trazido ao convívio das outras personagens e do público por uma narrativa posterior.Tudo o que de misterioso e transcendente é próprio à sua natureza convém ao ambiente recolhido da noite e à privacidade e solidão do leito. Por entre as trevas, a luminosidade da visão torna-se mais clara e penetra melhor nos olhos da alma. Porque rodeado de silêncio, de solidão e de treva, o ser humano tem melhor capacidade de percepção, todo concentrado que está 
sobre a mensagem que o aborda. Por isso ela também contrasta com nitidez com o ambiente em volta e estimula a famosa dicotomia trevas / luz e todas as conotações objectivas e subjectivas inevitáveis (Persas 176-180, Prometeu 645646, Coéforas 32-37). A repetição do sonho com nitidez progressiva (Persas 176 180, Prometeu 645, 655-656) ou a sua aparição súbita e única são processos contrastantes de comunicação do além, mas ambos produzem um efeito paralelo: quer a penetração no espírito se faça pela persistência que vai introduzindo um lastro progressivo de preocupação, quer o atinja com o fulgor instantâneo de um raio, o efeito emotivo que provoca é devastador. A reacção exterior é inevitável; impõe a comunicação, exige a confidência, necessita de um intérprete, ou mesmo, quando o seu alcance é íntimo e atinge fibras delicadas da alma humana, explode em gritos e manifestações de aflição. Clitemnestra, debilitada pelo crime e pelo remorso, apavorada pelo temor da vingança, reage com aparato à visão nocturna: lança gritos de horror (Coéforas 34-35, 535), acorda e salta do leito, procura afogar na luminosidade das tochas o efeito devastador da visão oculta nas trevas e calar as ameaças do além com oferendas (523, 525, 535-537). Para além destas reacções mais exaltadas, que convêm a certos estados de alma, é invariável a necessidade da confidência; ocorre então o relato do sonho, minucioso mas acrítico, feito por quem viveu directamente a experiência ou por aquele a quem ela foi confidenciada. É a partir desta narrativa que o sonho se integra definitivamente na acção, em cena.

Em geral, os sonhos têm uma forte componente visual, exprimem-se por imagens sem palavras, mas capazes de falarem pela expressividade dos símbolos que usam. São portanto apelativos ao sensorial, numa primeira manifestação, e exigem, na narrativa que Ihes dá voz, a repetição da ideia de 'ver' (Persas 179 , 188 ,200). São breves na comunicação, valorizam apenas alguns elementos sobre os quais retêm a atenção do seu destinatário. Mas primam pela ambiguidade de interpretação; a distância que separa a aparência, captada pelos sentidos, da realidade que o espírito procura a custo alcançar traduz-se pela repetição de 'parecer, ter a impressão, julgar' (Persas I81, I88, Coéforas 527).

Atossa descreve o sonho que teve com precisão de pormenores, onde os símbolos relevantes para o sentido global da peça são evidentes (Persas |8|200): o primeiro motivo tem a ver com o trajo que reveste duas mulheres, de estatura e beleza superior ao comum; se a estatura invulgar é o alerta para o carácter transcendente da imagem, o trajo persa de uma e dórico da outra definem uma identidade. Mais do que tornar presentes os dois mundos em 
litígio, o trajo aparatoso da Pérsia em contraste com a tradicional sobriedade dórica põe em confronto também os dois nomoi. Depois a luta que as envolve e que Xerxes procura acalmar. Com o jugo que lhes lança ao pescoço, o rei persa repete um elemento permanente em toda a peça, que traduz uma ideia geral de domínio ou submissão, a que não é alheio algum excesso. A reacção de ambas exprime-se com obediência de um lado e com rejeição violenta do outro; o acto de quebrar as rédeas e de sacudir o jugo arrasta para a queda o auriga deste carro de poder, Xerxes. Dario, o rei da prosperidade, aparece pronto a lamentar o sucedido, enquanto, prostrado, o jovem rei, senhor da imprudência, rasga as vestes em sinal de derrota e de ruína. Este é um sonho de sentido colectivo, cuja mensagem não suscita muitas obscuridades, mas sobretudo confirmações.

Mais pessoal, ainda que susceptível de uma abrangência mais ampla para a cidade, o sonho da rainha de Argos segue uma linha de transmissão também visual e enigmática. $\bigcirc$ pavor que aflige Clitemnestra e a ilegitimidade da sua situação recomendam-lhe a intimidade doméstica. Na sua ausência, são as mulheres do coro o porta-voz do sonho e das reacções que causou à assassina de Agamémnon (Coéforas 523-539). Mas também esta visão se alimenta de tópicos, sensíveis no diálogo em que as coéforas respondem às perguntas de Orestes. Não se trata aqui de narrativa, mas de um questionário que conduz à necessária interpretação final. A maternidade dá o tom geral ao quadro nocturno: Clitemnestra julgou dar à luz uma serpente, que rodeava de cuidados maternos e a quem amamentava. No fruto do seu ventre, a serpente, estava reunida a ideia de filho e de perigo de morte, que o acto de amamentação confirmou: o leite alvo e sereno misturava-se ao sangue rubro e violento, numa fusão cromática de maternidade e matricídio. Orestes percebe a mensagem e produz dela, sem hesitação, a leitura correcta (542-55I), que é também para ele uma mensagem decisiva: é chegada, de acordo com a vontade divina, a hora da vingança.

O sonho que lo narra no Prometeu (645-657) obedece a um plano dramático diverso dos anteriores. Esta é uma experiência do passado, vivida pela própria, cujos efeitos justificam um destino que a amada de Zeus já sofreu. $\bigcirc$ seu relato é apenas uma memória do tempo em que uma triste sorte se anunciava para uma jovem princesa. Curiosamente o sonho de lo não se serve de imagens, é ao ouvido que ele se dirige. Fala, e usa palavras que não são de violência, antes doces, persuasivas e sedutoras das aspirações românticas de 
uma donzela. Prometem uma aventura amorosa, onde o próprio Zeus assumirá o papel do apaixonado. Mas nem por isso deixam de ser ameaçadoras, porque o desejo de um deus não admite recusas nem demoras; e já um cenário se vislumbra em imaginação: aquele prado verdejante e tranquilo, onde pastam os rebanhos férteis de Argos, será a moldura ideal para um encontro, que no entanto não é de amor feliz e consentido, mas de uma temida violação.

Ao sonho segue-se sempre uma reaç̧ão, muitas vezes determinante para a evolução da peça em direç̧ão a um clímax. Mesmo se a obrigatoriedade do cumprimento é algo que faz parte da natureza profunda do sonho, o mortal que nele vê um sinal perturbador, explícito ou ambíguo, tende sempre a reagir: numa tentativa ingénua de interferir na ameaça que ele promete, ou no desejo de perceber as suas implicações. Proceder a rituais e a oferendas pacificadoras é um comportamento comum a Atossa e Clitemnestra. lo sentiu-se perturbada e atónita diante da mensagem divina e quis esclarecê-la (656-672). Através do pai foram consultados os oráculos, que somaram às palavras do sonho novas fórmulas igualmente obscuras. Só o tempo trouxe a resposta ansiada: tal como os rebanhos de seu pai, a jovem deveria trocar o palácio pelo exilio, errar sem destino como animal sacrificado aos deuses e sua propriedade. A exigência divina vinha acompanhada do castigo, a aniquilação de toda uma raça pelo raio fulminante de Zeus. Mau grado a discordância das vontades humanas, o destino de lo estava traçado; um périplo de desgraças se iniciava com a expulsão do palácio de seu pai.

De entre os fragmentos de Ésquilo parece haver alguns indícios de que um outro sonho ocorria no Glauco de Pótnias, a terceira peça da mesma trilogia em que figuravam os Persas ${ }^{53}$. Depois que Glauco sai de Corinto para participar, em lolcos, nos jogos fúnebres em honra de Pélias, alguma apreensão parece instalar-se no seu palácio, com origem num sonho (fr. 36b 2 Radt). O vocabulário convencional de 'parecer' (fr. 36b I) e a referência explícita a 'sonho' (fr. 36b 2) não deixam sobre isso grandes dúvidas. Dentro da linha habitual, talvez seja uma mulher a intermediária dessa visão (fr. 36b 2); na opinião de A. Moreau ${ }^{54}$, este papel poderia ser cumprido pela rainha, a esposa de Glauco, Eurímede ou Eurínome, que transmitia ao coro a sua angústia. Parece claro, pela insistência em

53 Vide A. Moreau, 'La tétralogie des Perses a-t-elle une unité', Cahiers du Gita 7 (1992/ 1993) 128.

54 Op. cit., 128. 
vocabulário das corridas de cavalos (fr. 36b 3), que o sonho tinha a ver com este motivo e eventualmente anunciaria um acidente próximo para o seu marido nos jogos em que partiu a participar. Referências a vitória talvez sugiram palavras de esperança com que o corifeu tentava acalmar as apreensões reais (fr. 36b 2). Se esta observação, muito limitada pela má condição dos fragmentos conservados, está correcta, tudo indica que este sonho obedecia, nas suas linhas gerais, a uma convenção que os textos conservados comprovam.

\section{O silêncio}

Deve-se a Aristófanes, e ao relevo que deu aos silêncios como uma estratégia colaborante no efeito de magnificência característico do teatro de Ésquilo, a chamada de atenção para um elemento ilustrativo de uma técnica usada com mestria pelo velho dramaturgo (Rãs 908-930). No agôn que opõe Ésquilo a Eurípides pela posse do trono da tragédia, este último, a título de exemplo de um falso empolamento com que $\circ$ adversário pretendia surpreender o público e engrandecer o teatro, cita o silêncio trágico utilizado com requintes de aparato pelo rival. Que fatuidade sentar um Aquiles ou uma Níobe diante dos espectadores, no início da peça, de cabeça baixa e de rosto velado, e deixá-los nessa atitude um lapso de tempo capaz de criar a surpresa e a solenidade no anfiteatro, uma perfeita 'exibição de tragédia'! (Rãs 9| I-9/3). Com uma síntese eficaz de um processo, Eurípides traz à discussão os seus pontos essenciais: exemplos paradigmáticos que, para o estudioso moderno, correspondem a peças perdidas, contextos prioritários para o efeito no plano da acção, aparato cénico e a estratégia dramática na gestão do motivo.

Taplin ${ }^{55}$ aprecia o efeito que os silêncios dramáticos podem obter no teatro de Ésquilo, e a forma como o autor os explora. A atenção dos espectadores é atraída por um foco, que o poeta centra sobre a personagem muda. Após uma longa concentração, em geral preenchida por outras figuras que comentam ou se interrogam sobre esta mudez e por isso mais a valorizam, o momento em que o silêncio é quebrado ocorre enriquecido por uma grande densidade emotiva. A personagem expande, enfim, a razão do seu silencioso cogitar. E usa uma linguagem empolada, o que nas Rãs faz a ligação com um

55 'Aeschylean silences and silences in Aeschylus', HSPh 76 (1972) 57-97. 
outro tema da caricatura esquiliana: a magnificência da sua linguagem. Aristófanes recorda dois momentos significativos da cena esquiliana: os silêncios prolongados de Aquiles e de Níobe, que seriam momentos de forte intensidade emocional. Ésquilo explora o suspense, estimulando a curiosidade do público com o prolongamento do silêncio. Só quando o drama atingia a metade, a personagem se dignava enfim falar (Rãs 924); e fazia-o com uma solenidade inesquecível, onde Ésquilo primava na majestade natural do seu estilo.

Outros testemunhos da antiguidade confirmam as informações de Aristófanes no que respeita à atitude de Níobe, na abertura da tragédia que tem o seu nome ${ }^{56}$. Apesar da controvérsia de opiniões, o fr. 154 Radt parece corresponder a uma rhesis talvez atribuível, de preferência à própria Níobe, a outra personagem amiga ou parente da heroína. A.W. Pickard-Cambridge ${ }^{57}$, por exemplo, opta pela hipótese de que o texto ficaria bem na boca de Antíope, a mãe de Anfíon marido de Níobe; mas uma ama ou a mãe da própria heroína são outras hipóteses sugeridas. A essa personagem cabia explicar, a um coro surpreso, a razão do silêncio e abandono da jovem, sentada, há três dias, de rosto velado, sobre o túmulo dos filhos (fr. 154a 6-7) ${ }^{58}$. Esta exposição deveria seguirse a uma abertura que exibia uma Níobe sentada e silenciosa, mergulhada na dor do luto, enquanto o coro cantava uma ou mais longas odes, para por fim dialogar com uma personagem, talvez Antíope (cf. 5 e 14, versos em que a personagem usa segundas pessoas do plural como seus interlocutores).

No que respeita ao silêncio de Aquiles, a nossa incerteza é maior. O schol. Ra. 9 I I informa sobre uma dupla alusão à apresentação de um Aquiles taciturno diante do público: 'Com toda a probabilidade, Aquiles em Frígios, também intitulada $\mathrm{O}$ resgate de Heitor, como em Mirmidões, não pronunciava uma palavra durante três dias' 59 . Muito provavelmente as duas tragédias faziam parte da'

56 Vita Aeschyli 5; schol. A. Pr. 436; Eust. Od. p. 1941, I, II. 1343, 62.

57 'The Niobe of Aeschylus', in Greek poetry and life (Oxford 1936) 106-120.

${ }^{58}$ Esta é uma descrição muito próxima da que é feita pela Vita Aeschyli 5:'Na Níobe, até ao terceiro episódio, a heroína ficava sentada sobre o túmulo dos filhos, de rosto velado sem dizer palavra'.

59 A. Garzya, 'Sui frammenti dei Mirmidoni di Eschilo', in De Homero a Libanio, ed. J. A. López Férez (Madrid 1995) 46-47, lembra o contributo importante da cerâmica, onde com frequência se representa a embaixada a Aquiles. Mas em nove vasos da primeira metade do séc. $\vee$ a. $C$., há uma confluência compositiva na representação de Aquiles: sentado, de cabeça coberta com um manto, com a mão direita sobre a fronte de forma a manifestar abatimento. Ora esta figuração do herói não coincide com Homero, mas sem dúvida com a Aquileida de Ésquilo. 
mesma trilogia, a Aquileida. Os estudiosos modernos repartem-se, mas parece talvez mais forte a posição que favorece os Mirmidões como a peça que Aristófanes tinha em vista. Taplin ${ }^{60}$ apura de Rãs um argumento poderoso para esta opção: o facto de a crítica de Aristófanes agrupar duas personagens, Níobe e Aquiles, silenciosas desde o início das respectivas tragédias, enquanto o coro fazia ouvir o seu canto. Ora Frígios, ao que sugere a Vita Aeschyli 6, parecia abrir com a presença de Hermes que mantinha com Aquiles um breve diálogo; enquanto os Mirmidões abriam efectivamente com o párodo em anapestos, em que o coro interrogava um Aquiles silencioso (cf. Rãs 992; fr. I 3 | Radt). Mas este eventual objectivo mais directo do comediógrafo não exclui a hipótese de haver em Frígios também um silêncio de Aquiles. Taplin ${ }^{61}$ imagina o herói nessa peça, na presença de Príamo e de um coro de Frígios, sentado e ensimesmado, durante todo o tempo em que o coro executava uma coreografia memorável, para além do necessário a uma intervenção de Príamo. Parece portanto aceitável que, independentemente de uma menção directa de Aristófanes, o silêncio de Aquiles fosse um elemento de relevo nas duas peças, ou seja, em diversos momentos de uma trilogia de que o herói da Ftia é o centro. A. Garzya ${ }^{62}$ concebe até diferentes motivações para 0 silêncio nas duas tragédias: 'Na primeira parte dos Mirmidões não ocorreu ainda a morte de Pátroclo, mas nos Frígios sim; por isso, enquanto Aquiles na primeira peça está mudo em função da ira funesta que o devora e o isola nos seus pensamentos, na segunda encontra no silêncio um refúgio para a dor; logo o seu mutismo aproxima-se, neste caso, do de Níobe'. No fr. I 32b 7-8 Radt dos Mirmidões, o próprio Aquiles alude a esse seu longo silêncio: é motivado pela amizade por Fénix que quebra o mutismo, depois de resistir a tantos e terríveis discursos sem uma réplica (provavelmente uma investida do coro de Mirmidões, atemorizados com o ataque inimigo junto às naus; seguida da abordagem oficial de um arauto, talvez Taltibio, em nome dos interesses aqueus; a que se acrescentaria ainda a palavra persuasiva de um guerreiro, talvez Ulisses). A austeridade destas figuras lutuosas estava claramente de acordo com o carácter quase hierático de uma tragédia ainda pouco movimentada. J. de Romilly ${ }^{63}$ considera essas imagens 'quase excessivas à força de sobriedade'. Está, porém, fora de causa o efeito destes

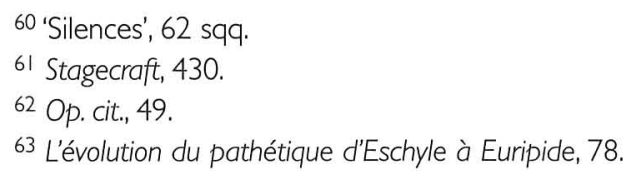


momentos e a sua legitimidade dramática. Dioniso, o perito na matéria e árbitro da contenda em Rãs, confessa a sua adesão a esses silêncios e como se rendia ao seu atractivo (Rãs 9|6-9|7), preferência a que o espectador moderno não tem dificuldade em aderir. Apesar, naturalmente, de não dispor dos grandes exemplos com que o deus do teatro se seduzia com o processo.

No entanto, a produção conservada de Ésquilo preserva alguns silêncios significativos; carecem da força dos que se perderam e não obedecem estritamente ao padrão definido por Rãs, mas mantêm mesmo assim algum atractivo. Nenhum dos silêncios conservados ocorre no prólogo, incidindo sobre uma personalidade central, com toda a carga de suspense que reconhecidamente esta estratégia traz ao conjunto. Reside decerto nesta dupla circunstância - a prioridade dada ao silêncio no tempo da acção e na incidência sobre uma personagem central - o carácter paradigmático do seu uso nos casos citados por Aristófanes. Mas, ainda que desligados entre si, os dois factores em causa são também reconhecíveis nos exemplos que podemos observar.

Atossa nos Persas, depois de questionar os velhos conselheiros sobre a identidade do inimigo que o exército de Susa partiu a combater, é surpreendida, juntamente com os seus interlocutores, pela chegada de um mensageiro capaz de satisfazer com pormenor a sua curiosidade (246-248). A rainha é uma personagem feminina, a única de resto na peça respectiva, a primeira com quem o coro dialoga e a quem a acção confere relevo. Logo a sua reaç̧ão de silêncio deve importância a todos estes factores. Durante o tempo em que decorre um diálogo epirremático entre o coro e o recém-chegado (256-289), a soberana ouve as notícias em silêncio. Talvez alguma limitação no uso simultâneo dos dois actores em diálogo com o coro traga a este mutismo uma explicação antes de mais técnica. Mas nem por isso o poeta deixa de tirar desta circunstância algum benefício teatral. Porque a própria Atossa, quando retoma a palavra, comenta 0 seu silêncio como uma expressão de dor e do esmagamento que a confirmação de terríveis notícias acrescentou a uma angústia prolongada (290-292): 'Há tempo já que me reduzo ao silêncio, pobre de mim, acabrunhada pela desgraça. $\bigcirc$ desastre é grande demais para permitir palavras, ou uma pergunta sobre 0 nosso sofrimento'. Assim, a sua reacção seguida do respectivo comentário assinala à sua maneira, e em contraste com os lamentos exuberantes do coro, um momento crucial na peça: aquele em que as suspeitas cedem lugar às certezas. $\bigcirc$ comentário ao silêncio, que é frequente e vem valorizar-lhe o efeito e estimular a adesão do público, é, neste caso, produzido pela própria 
personagem que dele tinha usado. Simples na sua justificação, é marcado pela insistência na dor que acabrunha e aniquila o sentido das palavras.

Depois da visita de Oceano ao seu local de exilio e após a oferta de uma intervenção junto do senhor do Olimpo, o autor da sua condenação, Prometeu, que lhe recusa a generosidade por inútil e arriscada, cai no silêncio (Prometeu 396). E é sob esse mutismo que, de resto sem fugir a um comportamento convencional, o prisioneiro ouve o canto do coro que se segue, um lamento de solidariedade ele também e de repúdio pela violência arrogante do deus supremo. No tom que lhe é próprio, o coro apela à adesão dos povos da Ásia e da natureza que circundam este cenário de sofrimento (397-435). É então que o silêncio de Prometeu se quebra, depois que apenas algum adiamento das suas palavras o tornou sensível em cena, para além da observação que o próprio the reserva (436-438). É chegada a hora de o prisioneiro relatar a causa da condenação a que foi votado, os benefícios que, contra a vontade olímpica, dispensou aos mortais. Prometeu insiste em que o seu silêncio não é mais sinal de uma sobranceria que alguns julgam perceber na sua confrontação com os deuses. Ele é tão só uma marca de sofrimento, legítimo na vítima da ingratidão dos imortais de geração recente, que são também devedores do seu talento. $\bigcirc$ silêncio é portanto um momento de introspecção na hora crucial de avaliar a injustiça que justifica o seu castigo.

Dois silêncios famosos, por razões diversas, existem na Oresteia, o de Cassandra, no Agamémnon, e o de Pilades, nas Coéforas. A missão que Ésquilo reservou à profetisa troiana (vide Possuídos pelos deuses) de avaliar, num momento crucial em que o assassínio do monarca se avizinha, o sentido profundo desse crime, torna a cena em que o primeiro destes dois silêncios se executa climática na peça. Este é, sem dúvida, de todos os silêncios preservados o mais espectacular. Cassandra entrou com Agamémnon, sobre o carro do vencedor, como uma imagem sem voz mas coberta de enigma (Agamémnon 783). E do seu posto assistiu, em reserva total, à recepção feita ao rei pelo seu povo e pela sua casa. Na sua presença ganhou corpo o momento fundamental da peça, a morte de Agamémnon às mãos de Clitemnestra. Embora toda a atenção em cena e no auditório esteja concentrada deste lado da acção, Cassandra é um desafio que não permite um alheamento total da sua presença. Antes de entrar no palácio, Agamémnon faz-lhe uma referência ao formular à senhora da casa um pedido de acolhimento para a sua cativa (950-95I). Mas só mais tarde, depois da entrada do par real no palácio e de mais um canto de 
angústia do coro, Clitemnestra volta a chamar a troiana, ainda imóvel e silenciosa sobre o carro ( 1035). Tal significa que o silêncio de Cassandra persiste por um tempo longo e advém de um ângulo de desconhecido. Cassandra é uma estranha à cidade e à situação que nela se vive, uma estrangeira, que no drama tem uma única actuação. E no entanto é-lhe conferida uma importância insuspeitada. $\bigcirc$ silêncio não acontece desta vez para valorizar uma personagem principal ou para lhe destacar um sentimento novo ou aprofundado em consequência do fluir da acção. Esta reacção enigmática ajuda antes a construir uma personagem desconhecida, que nem por isso deixa de ser crucial num momento agudo da acção, e que a partir desse silêncio se revela.

Clitemnestra dobrou à sua vontade Agamémnon, que conduziu para o interior do palácio e para o altar do sacrifício a um só tempo. E volta, para conduzir Cassandra a igual destino. Como todos nós, Clitemnestra dela sabe apenas que é estrangeira, um troféu de guerra e a sua rival junto do marido, para além de ser uma outra vítima da sua ira. Ao seu convite, Cassandra responde ainda com a imobilidade e o silêncio, renitente e incompreensível (1035). Esta persistência desperta especulação em sua volta, o que significa a mobilização das atenções gerais; Clitemnestra fareja rebeldia e orgulho descabido da parte da cativa (1039); mais tolerante o coro interroga-se também sobre aquela desobediência, quem sabe se ditada pelo temor ou também pela arrogância( 1047-1049). Para o silêncio busca-se portanto uma razão no sentimento. Para se questionar também, face à proveniência bárbara da jovem, a questão da língua (1050- | 05 I): será por não entender o grego que ela não reage? Clitemnestra impacienta-se e desiste (|055-1056) de se fazer obedecer pela palavra. Convida ao uso do gesto para vencer a barreira da comunicação. E de facto o coro regista os primeiros sinais de movimento na cativa, a agitação que sacode uma fera capturada (1062- | 063). Na sua reacção, a soberana interpreta sinais de loucura e não desiste de denunciar alguma ousadia na jovem que recusa o jugo. $\bigcirc$ coro, por sua vez, apieda-se. É rodeada da controvérsia dos sentimentos que Cassandra passa do silêncio à revelação. Não há, no enthousiasmos que dela se apodera, nem arrogância nem incompreensão. Bem pelo contrário, o que a domina é a aceitação do seu destino e a visão profética do sentido profundo de tudo o que a casa real esconde. Com o seu mutismo Cassandra ganhou suspense e força, mas sobretudo a dignidade de ceder à morte: não por vontade da rainha, mas de Apolo; nem por uma ordem ditada pela falsidade de Clitemnestra, mas por 
vontade própria e livre de aceitar o que na sorte de cada mortal é inevitável. $O$ aparato com que o silêncio chega ao fim é de certa forma o retrato do triunfo de uma outra vencedora: a cativa troiana.

Construído dentro de um modelo mais discreto é o silêncio de Pilades nas Coéforas. $\bigcirc$ jovem aparece em cena desde o início da peça como companheiro de Orestes e, nessa qualidade, persiste como personagem muda qual sombra sempre presente ao lado do vingador. A sua presença é inesquecível para o espectador que o tem permanentemente diante dos olhos, ainda que o texto só muito raramente dê indicação de atentar na sua pessoa. Orestes recomendathe que se escondam no final do prólogo (20-21) perante a aproximação das mulheres do coro e de Electra. Com esta breve alocução, em que a personagem é referida pelo nome, passamos a ter dele a identificação precisa. Nada mais é necessário acrescentar de tal forma o mito consagrara o companheiro de Orestes. Pilades recua para uma sombra discreta durante todo o kommos, para merecer de novo uma menção rápida de Orestes (56I-562) no momento de montar o dolo que the permitirá, depois de aceite no palácio, executar a vingança. Nesta cilada, Pllades desempenha $\circ$ seu verdadeiro papel, o do companheiro de um desconhecido que chega, e dele Orestes espera que aja em uníssono consigo próprio. Curiosamente, na hora de falar, deverão fazê-lo com acento da Fócia (563-564), pátria de Pilades, como se Orestes prometesse o fim do mutismo do companheiro e a necessidade de combinar uma estratégia de discurso. Mas o golpe da vingança Orestes imagina-o exclusivamente seu, prevendo todos os passos dentro do palácio como uma odisseia solitária onde nada se espera do companheiro.

Quando a porta do palácio se abre para deixar sair Orestes ao encontro da mãe, depois de morto Egisto, Pilades regressa na sua posição discreta, seguindo os passos do amigo. Testemunha o conflito entre mãe e filho, que adia por momentos o matricídio. E tem aqui a sua única intervenção, escassa mas decisiva. No momento em que Orestes hesitava diante do seio materno em cumprir a missão que o trouxera de volta a casa, Pllades quebra o seu silêncio por três versos (900-902), os únicos que pronuncia na peça, mas que são determinantes; como a voz de Apolo que se ergue a exigir o cumprimento das suas ordens, Pilades recomenda a necessidade de se satisfazer a vontade divina, cuja força e capacidade punitiva não tem rival entre os homens. Exactamente porque o silêncio de Pilades parecia inquebrável nos impressiona a mensagem de que ele é porta-voz. No momento seguinte as últimas hesitações do filho de 
Agamémnon cederam e a vontade do deus de Delfos será cumprida. Pilades não ergue a espada para executar o golpe, mas com as suas palavras é um colaborador indispensável no acto da vingança. Cumprida também a sua missão, a figura de Plades dilui-se para que avulte, solitário, o matricida.

\section{O reconhecimento}

O reconhecimento é um motivo canónico da tragédia, ao qual Aristóteles dedica alguma atenção (Poética |452a 18 - |452b 8, I454b 19 - |455a 22) e sobre que define alguns pressupostos para garantir a sua eficácia. No teatro conservado de Ésquilo, o modelo de reconhecimento tem uma única ocorrência, mas constitui um passo famoso de Coéforas (164-243) que aproxima; depois de uma longa ausência, os dois filhos de Agamémnon, Orestes e Electra. D. W. Lucas ${ }^{64}$ chama a atenção para a popularidade desta cena esquiliana (recorde-se a alusão que lhe é feita por Aristófanes, em Nuvens 534, como se de facto todos os espectadores imediatamente a identificassem) e justifica-a por se tratar talvez da mais antiga ocorrência do motivo ${ }^{65}$ no teatro ${ }^{66}$. No que diz respeito ao seu enquadramento no curso da acção, esta cena obedece ao que 0 autor da Poética considera um percurso desejável (I452a 18-2 I): "Estas cenas devem resultar da própria estruturação da história, de modo a que provenham de factos anteriores, por via da necessidade ou de acordo com a verosimilhança. Faz uma profunda diferença se os factos acontecem em função de outros ou simplesmente depois de outros'.

No reconhecimento de Orestes e de Electra junto do túmulo de seu pai há um conjunto de confluências e de vontades determinantes. $\bigcirc$ jovem exilado regressa por ordem de Apolo e por determinação sua também, motivado por uma lei que o transcende de obrigação de vingança e por uma reivindicação do que legitimamente lhe pertence. Do outro lado, Electra vem prestar ao pai a sua homenagem para cumprir uma ordem materna, a da satisfação de um sacrifício

${ }^{64}$ Aristotle. Poetics (Oxford reimpr. 1972) 170.

65 Admitindo, no entanto, a hipótese de que na tragédia Édipo de Ésquilo um outro reconhecimento tivesse podido também ocorrer.

66 Sobre a tradição do reconhecimento na literatura épica anterior, vide J. Jouanna, ' Notes sur la scène de la reconaissance dans les Coéphores d'Eschyle (v. 205-2II) et sa parodie dans l'Électre d'Euripide (v. 532-537)', Cahiers du Gita 10 (1997) 77-82. 
suscitado por um sonho ameaçador, e para implorar também consumação de uma vingança de que o próprio ritual é a denúncia. De parte a parte, razões humanas e divinas convergem em harmonia, para reunir as várias motivações de um acto decisivo que é o cerne da acção da peça. Logo o reconhecimento resulta intrinsecamente do que o precede e é condição para a acção subsequente.

Cumprindo a essência deste tipo de episódio (cf. Poética 1452a 29-32), este reconhecimento é também a passagem da ignorância ao conhecimento entre pessoas, que vai produzir amizade e aliança, logo, em certa medida, felicidade. Depois de anos passados na Fócida, criado por Estrófio pai de Pilades, o filho de Agamémnon volta já na juventude, quando possui as forças necessárias à missão que vem desempenhar. Orestes necessita de apoio no seu regresso a casa, Electra de colaboração na recuperação da sua dignidade familiar e por isso este reconhecimento the trará também ventura. Mas o tempo de felicidade é momentâneo, porque mais não é do que condição para o desencadear de um processo violento que de novo traz o afastamento dos dois irmãos.

No movimento por que aproxima duas pessoas, o exemplo de Coéforas é o de um reconhecimento unilateral. Orestes conhecedor do lugar em que se encontra não hesita em reconhecer na jovem que se aproxima com o coro a sua irmã. Do esconderijo onde se oculta pode confirmar essa intuição e é com a certeza de estar diante de Electra que ele a aborda. Pelo contrário a filha de Agamémnon suspira pela vinda de Orestes sem supor nunca que o tem a escassos metros da sua pessoa. Este reconhecimento faz-se a partir de objectos exteriores, um modelo que Aristóteles considera menos eficaz (|454b | |9-2 |), combinado com o que o mesmo estudioso considera 'o reconhecimento que advém do raciocínio' (1455a 4-6): 'Um quarto tipo é o do reconhecimento de acordo com um silogismo tal como ocorre nas Coéforas: como chegou alguém que se parece comigo, e se comigo só Orestes se parece, logo foi ele que chegou'.

São os sinais exteriores que primeiro despertam a curiosidade e atenção de Electra, e antes de mais o anel de cabelo depositado sobre o túmulo de seu pai. Num ritmo esticomítico, de pergunta e resposta viva entre a jovem e o coro, Electra intui de imediato, pela semelhança da cor com a do seu próprio cabelo, a sua origem: são sem dúvida cabelos de Orestes (|68-178). De resto, o carácter íntimo da oferta de uma madeixa de cabelo a um morto exige que o ofertante seja do círculo familiar restrito. Esta é uma condição que facilita o raciocínio de Electra. Logo a descoberta impõe outra dúvida: como veio o anel de cabelo até ao sítio onde se encontra, trazido pelo próprio ou enviado por um 
intermediário? Uma pausa para insistir na emoção que o achado provoca - as lágrimas, os apertos de alma - preenche um breve intervalo de suspensão até que as certezas - 'sim, estes cabelos são realmente de Orestes', 179 - recuem para dar lugar a novas dúvidas - 'será de crer que estes cabelos sejam antes de outro qualquer argivo?', |87-|88. À dúvida responde a esperança, num flutuar constante de sentimentos que antecede a revelação (192-194). No momento em que Electra desistia de acreditar num objecto que não oferecia certezas absolutas, o achado de um segundo indício estimula de novo a certeza. Desta vez é a pegada que responde à pergunta fundamental sobre a vinda de Orestes; ela é o sinal inequívoco da sua presença porque também semelhante à de Electra. Nos pormenores, 'calcanhar, músculos do pé', a correspondência é inegável (205210). Atrás de uma confirmação para essa suspeita, Electra segue o rasto das pegadas e dirige-se a um irmão emboscado que agora se lhe mostra diante.

Foi sem dúvida Eurípides a primeira voz crítica a denunciar a pouca verosimilhança com que Ésquilo explora os sinais exteriores (Electra 509-537) com vista ao reconhecimento. Ao recriar a cena do reencontro entre Orestes e Electra, agora com a intervenção interposta de um velho servo, Eurípides recusa como insensatos os sinais em que o autor de Coéforas se baseara. Colocada perante um anel de cabelo e uma pegada, a Electra euripidiana critica a possibilidade de através deles se aproximar a identidade de um homem e de uma mulher: 'O que poderá haver de comum entre duas cabeleiras, se uma cresceu na palestra onde se exercita a nobreza máscula, e a outra se tornou suave pelo efeito do pente?' (Electra 527-529); 'Como poderia gravar-se, num solo rochoso, a marca de um pé? E mesmo se tal acontecesse, as pegadas de dois jovens, irmão e irmã, não poderiam ter o mesmo tamanho. $O$ homem tem um pé maior' (534-537). Antecipando-se à apreciação menos favorável dos sinais exteriores no reconhecimento, Eurípides vai mais longe e põe em causa a própria opção por um certo tipo de sinais que resulta inverosímil. Decerto as observações do autor de Electra não se isentam de uma relação com posições médicas debatidas na época, que punham em discussão a relação genética dos pais com os filhos e inevitavelmente dos irmãos entre si; mas a alusão à cena esquiliana assenta em excessivas coincidências para poder ser recusada.

É todavia face às certezas menos críticas da Electra esquiliana que Orestes avança ao seu encontro, guiado por uma certeza absoluta que parece aniquilar o reencontro teatral de duas pessoas. $\bigcirc$ jovem adianta o seu nome, afirma-se como aquele cuja presença a irmã percebera pelos sinais. Mas surpreen- 
dentemente a sua pessoa causa dúvidas que as suas marcas não tinham suscitado. Enquanto Orestes multiplica o pronome da primeira pessoa, 'eu', expondo-se sem reservas, Electra opõe-lhe o tratamento de 'estrangeiro', recusando a aproximação e a própria evidência. Na presença do irmão, Electra distancia-se como perante um estranho (220), receia-o como um desconhecido ou mesmo um inimigo, teme uma cilada de perigo ou de ridículo. São precisas mais provas: verificar, na cabeça a que $\mathrm{o}$ anel pertence, os vestígios do corte; ou mesmo usar o testemunho acrescido de uma peça de roupa, bordada pelas mãos de Electra no passado. A Eurípides não escapa de resto o ridículo obtido por esta última prova, que mais uma vez leva a sua Electra a comentar (54I544): 'Não sabes como eu era jovem quando Orestes foi exilado? Esta roupa de criança que eu teci para ele, como poderia ele usá-la agora, a menos que com o corpo as roupas não cresçam também?' Mas, como acentua Mejer ${ }^{67}$, não deixa de ser expressiva de uma ligação entre irmão e irmã, que representa uma expressão de carinho maternal que a verdadeira mãe, Clitemnestra, nunca soube proporcionar a Orestes. Mais do que um simples sinal material comprovativo de uma identidade, a peça de roupa envolve uma carga afectiva inegável.

Ésquilo encontra neste subterfúgio motivo para um retardamento dramático. Tanto mais aparatosa a emoção adiada; os gestos são contidos, discretos no texto, travados pelo perigo que os rodeia; as palavras são calorosas e mais exuberantes. $\bigcirc$ abraço, o grito de alegria mal se esboçam, enquanto os lábios se multiplicam em explosões de ternura em volta de um irmão que para Electra concentra a única ligação ainda possível numa família destroçada. Para esta jovem desfalcada de todos os laços domésticos, ele é o pai que a morte levou, a mãe que, mesmo se viva, lhe é devedora apenas de ódio, a irmã que o altar de Ártemis the roubou, e o irmão em quem deposita todas as esperanças de um futuro.

Ainda que oportuno na sequência da intriga, este reconhecimento é débil no recurso em que insiste a objectos exteriores, de alguma forma rápido no desfecho e isento daqueles arroubos de ternura a que a cena de Eurípides veio a dar um espaço inesquecível. Mas não perde propriedade como um contributo para as linhas temáticas relevantes na trilogia.

67 'Recognizing what, when and why? The recognition scene in Aeschylus' Choephori', in Arktouros. Hellenic studies presented to B. M.W. Knox (New York 1979) 119-120. 


\section{A morte}

É por demais conhecida a convenção dramática por que a tragédia grega ofereceu ao seu público o espectáculo da morte no âmbito doméstico e familiar. Depois de preparada e anunciada, decorre fora de cena, enquanto aos ouvidos das outras personagens, como dos espectadores, ela chega pelo som dos gritos à distância. Alguma inibição ou perplexidade se apodera daqueles que, conscientes do perigo, nada podem fazer para evitar a consumação da violência. É somente uma porta o que a separa das testemunhas que a acompanham e a temem, mas nada é mesmo assim possível fazer para a prevenir. A hesitação, a angústia, o temor, envoltos em interrogações e lamentos, ocupam o tempo breve da ocorrência. Se a morte for pública ou cívica, como a de um guerreiro tombado no campo de batalha, dela não há sinal próximo a não ser uma expectativa agitada, mas condicionada pelo desconhecimento e pela incerteza.

Um mensageiro faz a conexão entre o extracénico e o visível. Com uma notícia sumária ou com uma descrição pormenorizada, esse agente, mais ou menos envolvido no acontecimento, dá dele uma imagem visual. $\bigcirc$ aparato cénico não sai mesmo assim ferido por essa antecipação, porque se the segue com regularidade a exibição penosa dos cadáveres e a exploração vistosa dos pormenores que rodearam a morte. Este é o pretexto para a reacção daqueles de quem a vítima é próxima, de lamento e de dor em torno do herói, de execração e de insulto em redor daqueles cuja morte é um castigo merecido pelos seus crimes.

A morte é um acontecimento vulgar no palácio dos Atridas. Repetido de geração em geração, o derramamento de sangue deixa um lastro de culpa e de expiação, que se sucede numa cadeia ininterrupta e antiga, que é o eixo lógico do progresso da Oresteia. Por isso a espectacularidade da morte produz, ao longo da trilogia, quadros sucessivos que, como os próprios acontecimentos que a eles conduzem, funcionam em termos de réplica. No vocabulário, nas armas ou nos acessórios, como também nas relações entre carrascos e vítimas, as cenas de morte interligam-se como ecos articulados.

'Sacrifício' é, neste contexto, uma palavra chave, porque se a morte do conquistador de Tróia é fruto de causas múltiplas, o banquete dos filhos de Tiestes como o sacrifício de Ifigénia em Áulide avultam de entre elas, a gritar por compensação. Mais próximo e directamente relacionado com Agamémnon, o 
sacrifício de Ifigénia tem com a sua morte uma interligação fatal; do mesmo modo que a jovem é condenada à morte, como vítima indefesa e ingénua pelo próprio pai, também o executor o será num outro ritual, onde o sacrificador é a esposa e mãe. A simetria não advém apenas da vulnerabilidade da vítima e da ferocidade da executante, ou de um elo familiar estreito a uni-los; a aproximálos está também uma razão de causa e efeito, onde o segundo funciona de réplica imediata do anterior, condimentados ambos os rituais de sentimentos mesquinhos e pessoais que os conspurcam: a ambição descontrolada do comandante do exército aqueu, e o ódio de uma mulher contra o homem poderoso, o marido infiel e o pai sem escrúpulos.

O sacrifício em Áulide pertence ao passado, está para além dos limites do episódio que constitui a intriga do Agamémnon, mas a sua influência nos acontecimentos próximos é tão directa que the são feitas menções constantes e dele é dado, pela memória emocionada do coro, um quadro vivo. Este é um exemplo de morte simbólica - o sacrifício de uma vítima humana e jovem -, que traduz o excesso mortífero da ambição de guerra e dos valores másculos dos heróis. Porque revestiu o carácter de um ritual ilegítimo e desrespeitador da convenção, o sacrifício de Ifigénia tem o valor de um crime. Ao contrário do rito, o degolar da vítima não permitiu o esquartejar das carnes e o festim, pelo que se ficou por um acto de violência gratuita a exigir reparação (Agamémnon I50155). Na quebra dos gestos rituais, que não puderam ser cumpridos em plenitude, denunciou-se a deturpação do seu sentido e o carácter sacrilego que o marcou.

O quadro de Áulide retoma vida através do canto do coro (228-247), depois de ponderado e decidido pelo seu executante, o próprio pai da vítima. ○ que de 'impuro, ímpio e sacrílego' caracterizou este golpe mortal está patente na relação entre a vítima e o sacerdote, pai e filha, como na substituição do animal pela donzela. Porque humana e forçada a um sacrifício, a vítima reage e repudia o necessário consentimento para que o acto consumado seja favorável. Ifigénia suplica, multiplica-se em apelos e preces, reagindo com toda a força da juventude à morte que a ameaça. Mas a emoção de que ela é a imagem esbarra com a frieza e indiferença dos generais. Sem demora, o próprio pai dá o sinal para que o rito se execute, e a reacção da vítima torna-se instintiva e aguda: agarrando-se com desespero ao chão, ela tenta opor resistência à determinação com que mãos potentes a agarram e a erguem sobre o altar. Uma mordaça fecha-the a boca e impede-a de proferir palavras de imprecação. Dominada, do 
seu corpo desliza o véu festivo ${ }^{68}$, que exprime a sua qualidade de virgem destinada ao casamento, na rendição final de um corpo indefeso ${ }^{69}$. Só os olhos concentram todo o vigor de uma súplica derradeira, último sinal de aflição e de despedida de uma donzela que ainda na véspera enchia de cantos e sorrisos as festas da mansão paterna. O contraste entre a normalidade alegre, que é própria da juventude, e a condenação precoce de Ifigénia à morte, para além da fragilidade feminina contra a brutalidade máscula dos chefes do exército, dá deste ritual um quadro de violência gratuita e insensata que 'a cólera' doméstica se encarregará de redimir (151-155, 1235).

Quando, anos passados, Clitemnestra festeja o regresso de Agamémnon, o executor do sacrifício de Áulide, coberto dos louros da vitória, o público reconhece no tapete de púrpura que lhe guia os passos para o interior do palácio um caminho sem regresso. Quando a porta se fecha sobre o herói, todos sabemos que vimos Agamémnon vivo pela última vez. Aguardamos, guiados pela convenção, os gritos que nos anunciem a morte do Atrida; mas somos surpreendidos por uma suspensão na sequência inevitável, a cena de Cassandra como um momento de vibração intensa e de importância decisiva neste momento (vide Possuídos pelos deuses). Pelos olhos da vidente troiana revemos e alargamos as causas subjacentes ao crime que se prepara e aceitamos, como um castigo legítimo, a sua ocorrência. A ferocidade do assassínio irrompe das cores e da brutalidade das telas que passam pela mente da jovem profetisa. Antes que o golpe seja executado, é-nos transmitida a sua concretização em tons ferozes. Cassandra vê e interpreta: um outro véu vai enlear a nova vítima (Agamémnon I 126, I 382, 1580; cf. Coéforas 1000, Euménides 635), num sacrifício ritual que repete, agora em Argos, a atrocidade que vitimou Ifigénia ( I | |4- | | | 8, I | 26- I | 27, | 433, 1502- | 503). Ao lado do herói ferido de morte irá tombar a cativa troiana, testemunho vivo da sua vitória destruidora e da sua traição leviana ( | |39, | | 49, | | 72).

Só então, esclarecida a morte do Atrida, os gritos vibram do interior do palácio ( 1343 sqq.), enquanto os velhos do coro se agitam, divididos entre propostas de diferente actuação, mas na realidade sem condições materiais de

68 Sobre o sentido dos diversos tecidos associados com morte na Oresteia, vide R. D. Griffith, 'Disrobing in the Oresteia', CQ 38 (1988) 552-554.

69 Sobre o significado visual desta cena, vide A. Lebeck, 'The robe of Iphigenia in Agamemnon', GRBS 5 (1964) 35-4I; id., The Oresteia. A study on language and structure, 8I-84. 
agir. Uma hesitação sobre o sentido do sinal fatídico, que só acentua o suspense, ocorre: terá de facto o soberano tombado, ferido de morte?

Todas as dúvidas terminam com a exibição em cena de um quadro de horror. Pela porta do palácio, aberta de par em par, surge finalmente a imagem da morte. Lado a lado, prostrados como dois amantes, Agamémnon e Cassandra jazem ensanguentados (1438-|443), enquanto de espada erguida, no próprio lugar onde atingiu o inimigo, Clitemnestra sustém ainda a vibração de um último golpe. O espectáculo acompanha a narrativa, porque desta vez é mensageira a própria executora (1372-1398). Clitemnestra saboreia a crueldade do quadro, que é obra sua, e que ela analisa em cada pormenor. $O$ tecido, que como uma rede serviu de armadilha à vítima, envolve agora um cadáver coberto de sangue, de que algumas gotas mancham, como insígnia de vitória, as mãos da matadora. Neste motivo da rede que envolve e manieta uma vítima sem fuga se alude à caçada que o próprio Agamémnon desencadeou contra Tróia (355-361). O espectáculo é uma nódoa de desonra sobre o guerreiro mutilado às mãos de uma mulher, talvez ainda mergulhado na banheira como sinal máximo da sua humilhação. Um golpe a mais, inútil quando Agamémnon cedia já à morte com um suspiro leve, completou um manjar de violência para satisfação exclusiva de quem o desferiu. Este quadro, que o espectador é chamado a rever repetidas vezes, a vários tons consoante o seu narrador (Cassandra que o antevê rodeada ainda da incredulidade geral, mas pessoalmente envolvida como vítima do mesmo massacre; Clitemnestra que, perante o espanto de todos, se regozija com o acto cometido; Orestes que o relembra na hora da vingança), regressa uma vez ainda no tribunal de Atenas. Desapaixonado nesta circunstância, é Apolo como defensor de Orestes a recordá-lo (Euménides 625-637) como a causa decisiva do matricídio. Esta insistência, em que o tom varia enquanto os traços fundamentais na execução do crime persistem, é um factor de coesão da trilogia. Convirá recordar neste momento a oportunidade do comentário de $\mathrm{A}$. Burnett ${ }^{70}$ : No Agamémnon, somos levados a perceber uma justiça pessoal e também cósmica no assassínio do rei, um assassínio que é exibido de uma forma horrenda. A exibição do cadáver é um insulto, com que o espectador se reconcilia porque conhece $\mathrm{o}$ grau a que este homem exasperou a Fúria e Clitemnestra. Logo os efeitos externos da morte são mostrados como a extensão da sua qualidade punitiva interna'.

70 'Curse and dream in Aeschylus' Septem', GRBS 14 (1973)345. 
Para que se cumpra a convenção, seguem-se os lamentos finais, que revestem um tom misto e controverso, como controverso é o estado de espírito argivo em relação ao monarca defunto (| 489-1566). Ao sentir diverso de cada um dá expressão um tom diferente do texto. Como fiéis que, apesar de tudo, continuam a ser, os velhos do coro entoam o treno em honra do morto. Multiplicam palavras de amizade e de dedicação, lastimam o fim trágico de um herói humilhado. O seu canto é lúgubre, doloroso e emocionado. Um refrão que se repete traduz a ideia obsessiva em quem o entoa: o dolo, a traição e o opróbrio de que se cobriu a morte de um homem superior. Ao coro responde Clitemnestra, a esposa privada do marido. Somente ela não pode, pelo paradoxo da situação que se vive, assumir o papel legítimo da viúva. $\bigcirc$ lamento esbarra com a impossibilidade de uma esposa, que é também a assassina do marido, de fazer as suas exéquias fúnebres. Clitemnestra não chora nem se dobra ao luto. Em tom firme, relata ofensas, argumenta com penas e vinganças, acusa e defende-se. Mas fica alheia aos rituais, incapaz de cumprir a sagrada missão de prantear a morte dos que pelo sangue ou pela ligação familiar the são chegados. À voz de Clitemnestra vem juntar-se a de Egisto, também ele incapaz de um lamento, porque cúmplice no ódio e na violência. Cobarde embora, incapaz de emprestar acção ao golpe, relata ressentimentos e acusa o cadáver que agora não representa mais concorrência e perigo. Palavras de lamento não cabem nesta execração em que se comprazem os inimigos de Agamémnon.

Esta imagem perdura na retina do público e na cena com que abre a segunda tragédia da trilogia, Coéforas. Os ritos que não cumpriu na hora própria, deixando sem homenagens o rei de Argos, Clitemnestra vai prestá-los mais tarde, quando o tormento do remorso e da ira divina a assalta. À distância, sem se expor fora do palácio ou ousar aproximar-se do túmulo, a rainha envia oferendas propiciatórias e tenta reparar a omissão de outrora. Mas já o rito fúnebre engloba, por uma coincidência orquestrada por desígnio divino, o vingador e se transforma, de acto de lamento, em conspiração de vingança. É para os assassinos chegada a hora da punição e duas novas mortes se preparam que, como reparação das anteriores, constituem delas a imagem em reflexo.

Tal como antes Clitemnestra desenrolara à vista do público o tapete de púrpura sobre o qual, à traição, atraíra a uma emboscada a sua vítima, também Orestes prepara, à vista de todos, o contragolpe. Ao comando dos seus cúmplices, o vingador concebe uma retribuição com armas iguais (Coéforas 555- 
584): o dolo será a sua estratégia principal, o enleio num tecido que trava qualquer resistência; ao acto dará o seu auxilio a vontade de Apolo, como antes a de Zeus e a cólera divina. Num retorno à chegada de Agamémnon a Argos, também o vingador irá regressar de uma longa ausência para ser recebido no palácio, sem pompa mas com a hospitalidade devida aos hóspedes. Ele próprio vai chegar despojado de todos os sinais de prosperidade, tão somente como um estranho, a pé, com os acessórios simples de um viajante anónimo. Tem de bater à porta e de interpelar o criado de serviço, até ter acesso aos senhores da mansão. $O$ dolo que Clitemnestra envolvera em luxo e aparato cobre-se, no plano de Orestes, de uma temível naturalidade. Clitemnestra retoma o seu papel de anfitriã, disposta a acolher o procurador da sua vítima, o seu próprio filho. Pela mão de Orestes, a autoridade masculina disputa mais uma vez, diante da rainha, o seu legítimo lugar no trono. Mas o cérebro que comanda o quadro, que repete no cenário a tela do passado, mudou de campo. É agora o recémchegado quem organiza e gere a acção, é ele que oculta sob palavras de dedicação a lâmina pronta a ferir. A vítima que alveja é, na preparação da armadilha, Egisto (57|-578), como se por um momento esquecesse aquele outro golpe inevitável para que o longo kommos o preparou: o matricídio.

Já o filho de Agamémnon acabou de penetrar no palácio de seu pai, sem ser reconhecido sob o disfarce de um mensageiro que viesse relatar a morte do próprio Orestes. $\bigcirc$ coro aguarda os gritos anunciadores da morte e julga ver, numa mulher chorosa que avança do interior do palácio, a sua relatora (72673I). Com um efeito, nos seus grandes objectivos, paralelo ao da cena de Cassandra, este episódio centrado em volta de uma outra mulher, a Ama de Orestes, suspende o golpe imediato para dar dele uma explicação ou justificação. Cilissa não tem clarividência, não sabe nem compreende por uma visão interior a verdadeira situação que decorre dentro do palácio, embora seja sua testemunha directa. Ela não reconheceu Orestes no recém-chegado, nem sabe o verdadeiro móbil do hóspede da casa. Mas nem por isso deixa de dar ao acto que se prepara o seu contributo. Como Ama de Orestes foi mais mãe do que a própria mãe; e é a denúncia que faz, intuitiva mas exacta, ditada pelo coração, do que é Clitemnestra como mãe, renegada, fria, perigosa, desapaixonada, que acrescenta, sem disso mesmo ter consciência, uma legitimidade e última justificação ao matricídio. Depois que parte a chamar Egisto e a reunir, no simples cumprimento de uma ordem, as duas vítimas do assassínio iminente, o público aceita não só a urgência do acto, mas a sua 
indubitável necessidade. Como a morte desta vez procede de fora para dentro do palácio, o coro no exterior está em condições de interpretar com maior exactidão um processo que, aos olhos dos que o vêem, não é perceptível. Pode até, ao contrário dos velhos argivos no Agamémnon, embaraçados perante um processo que não podem travar, dar a sua colaboração activa ao executor do novo golpe. Fá-lo não só em espírito, num apoio constante à necessidade da sua consumação, mas até com uma colaboração prática, corrigindo as ordens de Clitemnestra de forma que Egisto venha depressa ao palácio mas só, sem o corpo de guarda a protegê-lo (766-773). À vista do actual senhor do palácio estimulam-no a entrar, para ouvir de viva voz a notícia da morte de Orestes, que é doce - as mulheres não se iludem - aos ouvidos dos usurpadores. Também Egisto, como antes Agamémnon e Cassandra, caminha para a morte sem resistência. Apressa-se até a fazê-lo porque iludido com os verdadeiros motivos que $\mathrm{o}$ atraem a percorrer os degraus de acesso à morada régia, 0 'matadouro ensanguentado' dos Atridas. Não o perturba o aliciamento perigoso da púrpura, nem o toca a percepção de uma realidade ainda oculta a que adere de vontade própria. Egisto caminha para a morte sem suspeitas, numa inconsciência total e cega, que lhe dita as últimas palavras de uma ironia presunçosa (854): 'Desafio esse mensageiro a iludir a minha clarividência'.

O coro, porém, não se deixa enganar e diante da porta que se fecha sobre Egisto aguarda, em alerta emocionado, o sinal da vitória. Desta vez os gritos não se fazem esperar, o desfecho é breve, como é lacónica a descrição que um servo de imediato produz do ocorrido (870-877). Ésquilo reduz ao mínimo a morte de Egisto para dar ao matricídio, o cerne das Coéforas, um relevo sem concorrência. $O$ servo procura um interlocutor a quem transmitir a sua notícia. O coro, para disfarçar uma intervenção de cúmplice, arredou-se discretamente da entrada do palácio. E por isso é a uma Clitemnestra isolada, que sai dos aposentos ao barulho dos gritos, que os últimos acontecimentos são comunicados. A corrente de morte prossegue sem um momento de quebra. $\bigcirc$ servo não entende a solidão que cerca o palácio e o atraso da rainha. Formula até uma hipótese irónica: será que Clitemnestra, atingida pela morte de Egisto, se suicidou (88I-884)? Mas a rainha não deixa os seus méritos de inteligência e de frieza por mãos alheias. Ela compreende de imediato o sentido de tudo o que se passa, na mensagem que lhe é passada em palavras breves (886): 'São os mortos que ferem os vivos'. Entende o dolo, percebe a presença do vingador, mas não cede. Só a ingenuidade honesta de um servo poderia imaginar um 
suicídio, como a adesão de uma mulher fraca à morte do companheiro másculo. Mas essa não é a filha de Tíndaro que conhecemos. Em vez de ceder, ela prepara-se para a luta, num desafio final a si própria (890): 'Vamos saber se somos vencedores ou vencidos'. Já a porta se abre e Orestes se alinha para a luta, que é um desafio à sua determinação. Embora reserve o golpe final para a discrição do extracénico, Ésquilo prepara-o à vista do público. Mãe e filho, vítima e assassino, a tão desejada vingança enchem a cena.

O quadro de morte como o jovem o constrói é uma réplica do que uniu, num mesmo leito fúnebre, Agamémnon e Cassandra: que Clitemnestra se apresse a ocupar, ao lado de Egisto, o seu lugar. Desejoso de chegar ao fim, Orestes ergue a lâmina; pela primeira vez em todas as mortes que presenciámos, a vítima suplica. Para Clitemnestra o apelo que interpõe é mais uma táctica de um jogo perigoso - 'venceremos ou sairemos vencidos?' - do que uma verdadeira argumentação ditada pela dor e pelo sentimento. Mas vem coberta de espectacularidade e, por isso, coloca a um adversário mais fraco uma última hesitação. $\bigcirc$ grande motivo da súplica de Clitemnestra é a maternidade que ela expõe por todos os meios. Dispensa-se qualquer menção ao reconhecimento, porque para Clitemnestra, ao contrário do que antes sucedera com Electra, é claro quem tem na sua frente. Com um apelo insistente à palavra 'filho' (896), a rainha desnuda o seio como o símbolo de uma cumplicidade vital entre mãe e filho e como garantia de segurança para o recém-nascido. Mas decerto na mente de Clitemnestra e de Orestes, como na do público, o seio implica a recordação de um sonho recente, que veio estimular os receios de uma e a determinação do outro. Esse seio, de onde jorrava leite e sangue (vide Sonhos), é também o ponto onde o golpe será desferido. Mas o que parecia claro a Orestes, quando à distância interpretava essa visão, é agora, no momento supremo, uma terrível inibição. Dorido, apesar de todas as razões, por um apelo da natureza, o filho treme diante do matricídio. É Pllades, presente em cena e resguardado num silêncio persistente até agora, quem decide, como arauto de Apolo, o dilema. Estas serão as suas únicas palavras na peça (900-902). A atitude de Orestes reforça-se definitivamente; perante a sua decisão determinada são inúteis as razões interpostas por Clitemnestra: o apoio devido pelo filho à velhice da mãe, o peso do destino, a ameaça de maldição, a protecção que lhe foi garantida pelo exilio, as culpas de Agamémnon, as Erínias. 'Meu filho' é um brado repetido por Clitemnestra sem que a contrapartida 'mãe' saia da boca de Orestes nesta penosa esticomitia.Todos os apelos são vãos, até porque lhes falta 
uma emoção autêntica e soam a um simples desfiar de razões, de peso embora, mas enfraquecidas pela personalidade excepcional desta mãe.

Mãe e filho reentram no palácio, depois de Clitemnestra repetir, junto de Orestes, o fracasso que antes experimentara em relação a Cassandra; incapaz de atrair a troiana para o caminho da morte, de novo se mostra incapaz de impedir que Orestes a faça repetir o mesmo percurso. Porque entrar no palácio como sempre equivale à condenação. A convenção pode prosseguir com a agitação do coro, que entoa um canto à justiça, antes que a porta se reabra para um segundo quadro de morte. Desta vez os habituais gritos dentro do palácio não se fazem ouvir, decerto porque o orgulho de Clitemnestra lhos não permitiria. Sobre os dois cadáveres Orestes faz agora o seu próprio relato, mas num tom muito distante da raiva que ditava as palavras de Clitemnestra em circunstância semelhante (973-1006). Nos dois corpos que jazem a seus pés o vingador vê os tiranos de Argos e para o seu acto encontra, antes de mais, uma justificação política; mas neles reconhece também os assassinos de seu pai e os espoliadores de uma herança que the pertence, o que lhe fornece o direito de uma justiça familiar ou mesmo pessoal. Não é o amor que une os dois cadáveres que agora partilham o leito de morte, mas uma conivência de interesses de onde está ausente o sentimento. A fidelidade no entanto é visível na paralisação de dois seres humanos, que a morte tornou definitivamente cúmplices. A quem testemunha este quadro, Orestes convida ao necessário paralelo com a morte que ele vinga: um véu que enleou as vítimas de outrora reveste os seus carrascos, com a mesma traição e a mesma impotência que funde os dois actos num único. A simetria das armadilhas que eliminaram as duas vítimas é, ao vivo, a imagem concreta da pena de talião (cf. | | | | - | 013 ). O prazer do acto consumado não é para Orestes um gozo pessoal, mas uma espécie de oferenda devida aos deuses da vingança, a quem o jovem de certa forma dedica a vítima desejada, a esposa infiel. Uma imprecação denuncia também neste momento as culpas graves que condenaram uma mulher monstruosa. Egisto apaga-se para que um foco potente incida sobre a causa que verdadeiramente se anuncia: a razão de um castigo a uma só vez devido e indevido.

As imagens da morte na Oresteia vêm portanto envoltas em traços de excesso de violência, porque se deseja fazer delas paradigmas de culpa e de castigo. Acompanham-se de insultos e de censuras, para além dos lamentos, porque comportam desonra para os mortos e ressentimento dos vivos. Bem 
diferente é o caso de Sete contra Tebas no que respeita ao espectáculo da morte. Em termos breves e objectivos, um mensageiro alheio à sua execução acabou de trazer a notícia decisiva (8|4-8|9): Tebas está salva e vitoriosa, enquanto os seus dois chefes tombaram num duelo pela partilha de uma herança: o trono da cidade. A luta em causa significa fratricídio, um acto igualmente insuportável. Mas nada há no desfecho da peça que lhe acentue a violência ou a imoralidade. São omitidos quaisquer pormenores sobre os golpes trocados, o sangue derramado ou o ódio que moveu os guerreiros no confronto. Com as palavras do mensageiro o que se anuncia é a entrada dos despojos de uma catástrofe, ou seja, nas palavras de Taplin ${ }^{71}$,'primeiro ouvimos o relato do que aconteceu e depois vemos e ouvimos as suas consequências humanas'. Por isso logo de seguida os corpos são trazidos com discrição, poupados a insultos ou ao desprezo de quem os observa. A morte apresentase neste caso com dignidade, rodeada do pranto sóbrio e coeso das tebanas. Como elas próprias reconhecem, em palavras explícitas, a exposição dos cadáveres complementa a informação do mensageiro (848), o espectáculo culmina a rhesis. $\bigcirc$ tom das palavras proferidas é o do irremediável. A prostração profunda dos dois corpos é a expressão de mais um golpe radical desfechado sobre a casa dos Labdácidas. Perante essa imagem de dor, o coro executa um ritual de luto. As vozes embargam-se, as palavras faltám para exprimir tanta dor. A emoção substitui-se à razão, lamentos e gestos concentram todas as atenções. Por entre sons doridos, as mãos golpeiam a cabeça em ritmo certo e constante; tudo em volta, o solo e as muralhas de Tebas, ecoam os gemidos e associam-se ao lamento pela morte inglória dos seus senhores, dobrados ao peso de uma maldição que herdaram juntamente com o poder da sua pátria. $\bigcirc$ treno que os escolta é 'ruidoso, lancinante, gemente, sofredor, rebelde à alegria, capaz de extrair lágrimas do fundo da alma, que se consome em lamentos pelos dois reis' (915-920). Com exaltação crescente, as mulhres repartem-se em dois semicoros que, em torno de cada um dos cadáveres, aceleram os brados de dor pelos dois filhos de Édipo que, pelo aniquilamento, redimiram Tebas da condenação de ruína que a ameaçava ${ }^{72}$.

71 Stagecraft, 172.

72 Sobre a famosa questão da autenticidade do texto final dos Sete, vide O. Taplin, op. cit., 169-180;W. G. Thalmann, Dramatic art in Aeschulys' Septem against Thebes, | 37-|4I. A leitura que aqui fazemos exclui a presença das duas irmãs e a sequência de versos a partir do 1005. 
(Página deixada propositadamente em branco) 
Ésquilo autor de
dramas satíricos 
(Página deixada propositadamente em branco) 
Para além de celebrado criador de tragédias, Ésquilo ganhou reputação de autor distinto de dramas satíricos (Pausânias 2. 13. 6; Diógenes Laércio 2. I33). E no entanto, dessa faceta de criação altamente popular no seu tempo, o que chegou até nós é de certa forma desolador. Feito de escassos títulos e de fragmentos em geral muito sumários, a abordagem deste material mantém-se um constante desafio capaz de suscitar, sobre uma possível definição do género em causa, mais dúvidas do que certezas. No volume que dedicou aos fragmentos de Ésquilo, S. Radt ${ }^{73}$ vincula alguns desses dramas às respectivas tetralogias: 0 Prometheus Pyrkaeus à tetralogia de 472 onde se integram os Persas; a Esfinge com a tetralogia tebana de 467, de que fazem parte os Sete contra Tebas; o Proteu como correspondente à Oresteia, em 458; o Licurgo a concluir a Licurgia; e por fim Amimone, em 463, a integrar o mito das Danaides. Estão ainda identificadas como dramas satíricos mais seis peças: Dictiulcos (Pescadores à rede), Isthmiastai ou Theoroi, Circe, Kerkyon, Kerykes (Arautos), e Leão ${ }^{74}$.

Parece depreender-se dos vestígios conservados que o coro de um drama satírico é composto de sátiros, que, diversamente do que é a tendência na tragédia, não se limitam a fazer o comentário distendido e abrangente da acção, mas actuam por conta própria, como verdadeiras personagens intervenientes. É antes de mais por seu intermédio que o ascendente mítico é garantido nesta versão dramática, que decorre num ambiente fantástico, povoado de sátiros, de deuses e de heróis. Do seu aspecto físico, que se compõe de elementos híbridos como a cauda equina, as orelhas e a barba de bode, o sexo erecto, resulta evidente uma natureza própria, que se repercute no comportamento por um excesso intuitivo. Representando um padrão de criaturas diferentes do humano, os sátiros parecem remontar a um universo pré-civilizacional, próximo de uma physis para a qual o sexo e o vinho são os principais estímulos. Alguma sujeição ao respeito devido aos deuses faz deles fiéis sequazes de Dioniso, estatuto conveniente às suas

73 Tragicorum Graecorum Fragmenta III:Aeschylus (Gottingen 1985) III-I 19.

74 Outras hipóteses para alargar este núcleo são acrescentadas por Ph. Yziquel, 'Le drame satyrique eschyléen', 6-7. 
tendências naturais e estimulante da anomia que lhes é própria. A sua relação reconhecida com as Ninfas das montanhas e os Coretes dançantes anuncia a agitação de que também eles são capazes nas telas sem fronteiras de uma paisagem natural. Logo, mesmo se se enquadram num mundo selvagem e não civilizado, uma certa afinidade com o divino torna-se, apesar de tudo, um elemento de certo modo controlado dentro da ordem universal. Não é, portanto, ocasional que algumas palavras mesmo avulsas, que constituem uma parte dos fragmentos conservados, remetam para este contexto: cf. frs. 103, 107, I I 3 Radt.

A importância da sua intervenção confere ao sentido geral do drama uma tonalidade própria, de onde avulta antes de mais um sabor cómico ou caricatural. São também claramente provenientes da natureza dos sátiros alguns dos motivos que parecem projectar-se como característicos deste género. Coloquemos em primeiro lugar a lascívia. De entre os dramas satíricos esquilianos identificados, em dois parece avultar esta componente: Amimone e Dictiulcos $^{75}$. Apolodoro (2. ।. 4) recorda a versão, apoiada por várias representações na pintura cerâmica, da filha de Dânao, Amimone, atacada por um sátiro na fonte onde pretendia encher de água um cântaro. A donzela em perigo é salva do seu perseguidor pelo próprio Posídon; mas também o deus das superfícies líquidas do universo só consentiu em fazer brotar as nascentes de Lerna depois de ter conquistado pela persuasão o gozo dos encantos da Danaide, que soube seduzir e atrair ao casamento. Não será talvez arriscado atribuir a este episódio como atributos irrecusáveis, para além da lascívia do violador, a fragilidade de uma donzela ameaçada e o socorro garantido pela intervenção fantástica e aparatosa de uma divindade. À tela dos amores divinos por uma bela princesa convém por moldura um quadro da natureza, que perfuma de aromas delicados a atracção dos dois amantes. Na sua exiguidade, os fragmentos conservados não deixam de ser abonatórios destas sugestões: a menção dos aromas do nardo e dos perfumes (fr. 14 Radt), estimulantes do encanto e da sedução, acompanha duas referências à relação amorosa; a inevitabilidade do casamento entre dois seres, que parece decidida pelo destino, convém como promessa a qualquer um dos dois amantes, mas preferencialmente a Posídon (fr. I 3); o ataque feroz de um caçador sobre a sua presa, com o intuito de engendrar nela uma cria (fr. 15; cf. ainda fr. 47a 775 Radt dos Dictiulcos), convém melhor ao erotismo desenfreado do sátiro.

75 O Ciclope de Eurípides, que parece situar-se no mesmo padrão dramático, é também testemunha desta característica dos sátiros (w. 169 sqq., 187, 439, 498). 
Neste assalto erótico sobre a donzela indefesa está explícito o retomar do tema da violação, do repúdio pela união carnal e de uma possível reconciliação com o casamento que domina toda a trilogia das Danaides. A união finalmente aceite de Amimone com o deus traz ao episódio um desfecho feliz e em harmonia com o que parece ser também o sentido global das tragédias precedentes. Por essa união, Amimone garante continuidade à raça de Dânao ao mesmo tempo que Argos recupera, com a água abundantemente concedida por Posídon, o viço perdido. Com esta submissão à ordem natural do universo, a Danaide contribui para a reinstalação da desejada fertilidade dos homens e da terra.

Algumas afinidades aproximam o destino de Amimone do experimentado por Dânae nos Dictiulcos. No que parece ocupar a função de um prólogo dialogado, o fr. 46a Radt exprime a surpresa de dois interlocutores perante um prodígio: uma pescaria de tal modo extraordinária que resiste às suas forças. De dentro do mar, carregadas por um peso inusitado, as redes recusam-se a emergir, como se estranho presente marinho as retivesse. Perante a dificuldade, é lançado um brado de socorro (17) a que muito provavelmente o coro de sátiros responderia ${ }^{76}$. Com este grito a entrada do coro recebia uma justificação apropriada e dramaticamente eficaz.

prodígio revelava-se então quando, de dentro de uma arca salva das ondas, saía Dânae, a filha de Acrísio, soberano de Argos, com um rebento que gerara de amores divinos, Perseu. Igualmente vítima do desejo de um deus, desta vez do próprio senhor do Olimpo, a pobre princesa via-se em perigo nas garras da aventura, para ser salva por Dictis, o irmão do soberano da ilha de Sérifos. Muito provavelmente enquanto o salvador partia a garantir hospitalidade para a náufraga, Dânae via-se ameaçada pela lascívia de Sileno e dos sátiros (47a). Apesar das preces e do terror da sua vítima, os atacantes rejubilavam à ideia do prazer erótico (821-823) que a jovem e o momento prometiam. É acertada a suposição de Taplin ${ }^{77}$ de que ao movimento dos sátiros, que parecem organizarse num cortejo nupcial, se opõe o regresso de Dictis que Ihes frustra os projectos, abrindo caminho a uma nova salvação.

Além da lascívia, o susto perante o desconhecido parece ser também um traço permanente na personalidade dos sátiros. Esta é a reacção que resulta do seu encontro com um Prometeu que manipula o fogo, no Prometheus Pyrkaeus. Este encontro sugere a oposição possível entre o deus que contribui

\footnotetext{
76 Cf. S. Ichneutai, onde ao apelo de Apolo respondem também os sátiros.

77 Stagecraft, 419.
} 
poderosamente para o progresso da civilização entre os homens, perante a surpresa selvagem e ignorante do coro que o rodeia. Idêntica sujeição diante de um senhor, um monstro ou um mago parece ser um lugar comum discretamente sugerido por outros testemunhos conservados. Assim o fr. II 5 de Circe, expresso pela simples ideia de 'vou subjugar', poderia corresponder a uma ameaça da feiticeira contra os sátiros, dominados ao seu poder, para serem mais tarde libertados por Ulisses; a prisão estava-Ihes igualmente destinada no Licurgo (fr. 125), como também a libertação desta vez promovida por Dioniso; da sujeição a Cércion, tirano de Elêusis, libertava-os Teseu, o herói ateniense; por fim no Leão, talvez coubesse a Hércules proeza semelhante.

A mesma desadaptação às circunstâncias que revela a reacção selvagem dos sátiros parece mais claramente visível do que resta de Theoroi ou Isthmiastai, título alternativo para a mesma criação. Das duas palavras que designam esta peça parecem evidentes duas atitudes, que nela caracterizam o coro constituído por sátiros. Em primeiro lugar iremos vê-los actuantes no contexto dos jogos ístmicos, como atletas ou pelo menos candidatos a esse papel; enquanto de theoroi talvez se recolha a ideia de deputados ou representantes de uma cidade nos jogos realizados em Corinto. Dois comportamentos igualmente difíceis de fundamentar e de interpretar a partir das características do pouco texto conservado são no entanto possíveis e compatíveis com esta dupla legenda. Que a acção decorresse em Corinto diante do templo de Posídon, o deus patrocinador dos jogos (cf. 78a 22), não será muito especulativo. Como me parece aceitável a argumentação com que A. Melero ${ }^{78}$ defende a ideia de que este mesmo fr. 78a exprimisse um ritual com que os sátiros, na qualidade de atletas ou de deputados de uma cidade, homenageavam o deus ${ }^{79}$. A cerimónia reveste a solenidade própria com a menção do silêncio ( $V .4)$ e da prece ( $W$. I I12). O objectivo dos celebrantes é uma oferenda votiva, que se traduz na deposição no templo das suas próprias máscaras. Alguma surpresa diante de 'imagens não humanas', que se encaram como objecto digno de veneração, ressalta do fr. 78 a I-2. Pausânias $(2.1,7)$ e parece dar força à ideia de que os sátiros representam, na sua origem, um comportamento que se tornou tradicional no Istmo: o de dedicar máscaras ao deus. Do que julga ser o carácter

\footnotetext{
78 'Notas a los Teoros de Esquilo', in De Homero a Libanio (Madrid 1995) 59-60.

79 Este cerimonial como próprio da abertura dos jogos ístmicos é confirmado por Xenofonte (Hell. 4. 5, I-2).
} 
etiológico desta oferta dos sátiros, A. Melero ${ }^{80}$ adianta a hipótese, que não passa disso mesmo, de que este drama satírico tratasse o motivo da instituição dos jogos ístmicos. Talvez às mesmas máscaras se reportassem algumas expressões e palavras que encareciam a oferta elogiando-lhe a perfeição; estão neste caso morphe, 'a beleza' ( $w .6,19)$ e 'a reprodução digna de um Dédalo' (v. 7). Mas por trás da qualidade da oferta está o choque irónico entre esta perfeição do retrato e os traços grotescos do modelo. Em resumo, o tom dominante na primeira parte deste fragmento é o de um ritual satírico, propiciatório de Posídon, cujo centro é a oferta de máscaras possivelmente numa sugestão etiológica.

À concentração protocolar do ritual segue-se uma espécie de agôn ou conflito com uma personagem cuja entrada se anuncia a partir do v. 23, que deve ser Dioniso a julgar pelo protesto que ao deus merece ter sido depreciado como 'efeminado' (fr. 78a 68; cf. Ar. Tesmofórias 134 sqq.); além de que, como muito a propósito refere Melero ${ }^{81}$, os w. 37 sqq. do fr. 78 c contêm um vocabulário muito convencional na descrição poética do culto dionisíaco. $\bigcirc$ diálogo entre os sátiros e o deus parece conduzir à ideia de um contencioso entre Dioniso e os seus fiéis; desgostosos do mau tratamento ou da indiferença de que se julgam vítimas por parte do seu protector (fr. 78a 30-34; cf. E. Cyc. I sqq.), pretendem renegar o culto dionisíaco para se entregarem ao espírito ístmico dos jogos.

Com esta disposição dos sátiros talvez se abrisse o acesso à terceira parte do drama, aquela em que os novos atletas recebiam os atributos da competição (fr. 78c 50), para, desadaptados, os renegarem e se porem em fuga (fr. 78c 53). M. Stieber ${ }^{82}$ acentua o potencial cómico, comum no drama satírico, que resulta da desadaptação permanente dos sátiros às inovações tecnológicas; tanto mais sugestiva pela diferença com a naturalidade com que o público se encontra familiarizado com elas. $O$ fogo no caso do Prometheus Pyrkaeus ou os instrumentos de competição gímnica neste caso são do processo modelos evidentes.

Se deixarmos a intervenção coral e passarmos ao universo das personagens, constatamos que deuses e heróis são os agentes mais constantes no movimento da aç̧ão. Para além de um Posídon enlevado por Amimone, encontrámos já também um Dioniso em relação polémica com os sátiros em Isthmiastai. Um outro drama satírico, Licurgo, dava ao deus dos rituais báquicos uma previsível intervenção de relevo. Recusado pelos Edonos e expulso pelo

80 Op. cit., 6I.

81 Op. cit., 58.

82 'Aeschylus' Theoroi and realism in Greek art', HSPh 124 (1994) 91. 
seu soberano Licurgo, Dioniso luta e castiga com ferocidade os que repudiam o seu culto. Esta que é, em termos gerais, a linha de força de Bacantes, seria também o motivo central da tetralogia esquiliana. Enlouquecido por acção do deus, Licurgo vê-se privado dos seus prisioneiros, os sátiros, e apenas reintegrado na lucidez de espírito depois de ter trucidado o próprio filho.

Para além dos deuses, o universo do drama satírico comporta ainda uma participação activa dos grandes heróis do mito, sobretudo aqueles que se impuseram como eternos ganhadores contra inimigos sobre-humanos, animais e monstros. Hércules naturalmente figura à cabeça deste padrão. $O$ Leão desenvolve o tema da vitória do herói sobre o 'monstro local' de Nemeia (fr. 123), o seu temível leão. O mesmo herói e as suas façanhas de libertador regressavam em Arautos, onde os embaixadores de Ergino, em missão de ilegítima cobrança de impostos aosTebanos, se confrontavam com Hércules que regressava vitorioso do combate contra o leão de Nemeia. Duas referências à fera documentam o episódio: a menção da pele (fr. 109) e da cor fulva da cabeça (fr. I I0). Talvez o fr. I08, alusivo a uma ânfora de gargalo estreito, pudesse parodiar a voracidade muito convencional e sempre insatisfeita do herói.

Teseu, por seu lado, assegurava a derrota de Cércion, tirano de Elêusis que desafiava os estrangeiros para o combate e não poupava a vida aos que vencia. Dos escassos fragmentos conservados projecta-se a noção de um vocabulário técnico que alude ao combate: quer pela menção de pormenores de equipamento (fr. 102), quer das reacções ou atitudes de vencedores (frs. 105, 106) ou de vencidos (fr. 104).

Ulisses, o herói viajante, tinha também o seu papel a desempenhar em Circe. Talvez o fr. I I 3 a refira a palidez do náufrago em demanda de ĺtaca.

Por fim, a Esfinge completava a trilogia de Édipo com o que parece ser uma caricatura dos enigmas assassinos do monstro. Em vez de tomar a iniciativa de questionar e de vencer pela ignorância os que a defrontavam, a Esfinge era por sua vez interpelada por Sileno e vencida pela argúcia deste. Esta é uma hipótese permitida pelo testemunho da cerâmica (vide A. Moreau ${ }^{83}$ ).

Talvez ao tom próprio do drama satírico, a que não falta humor, erotismo e muita fantasia, Ésquilo tenha trazido o seu cunho pessoal; e esse poderia exprimir-se sobretudo no estilo poético, onde alguma dignidade e muita imaginação criativa assinalavam a personalidade conhecida do velho poeta.

83 'Le drame satyrique eschyléen est-il 'mauvais genre'?', Cahiers du Gita I4 (200I) 47. 


\section{BIBLIOGRAFIA}

S. M. Adams, «Salamis symphony: the Persae of Aeschulus», in E. Segal, Greek tragedy (Oxford reimpr. 1991) 34-41.

U. Albini, «Personaggi femminili nelle tragedie di Eschilo', PP 270 (1993) 176-I85.

H. Bacon, Barbarians in Greek tragedy (New Haven 196I).

A. L. Brown, «Eteocles and the Chorus in the Seven against Thebes», Phoenix 31 (1977) 300-318.

A. Burnett, «Curse and dream in Aeschylus' Septem», GRBS 14 (1973) 343-368.

H. D. Cameron, Studies on the Seven against Thebes of Aeschylus (Mouton 197I).

-«Les Choéphores d’Eschyle», coord. A. Moreau et P. Sauzeau, Cahiers du Gita 10, 1997.

D. J. Conacher, «Interaction between chorus and characters in the Oresteia», AJPh 95 (1974) 323343.

D. J. Conacher, Aeschylus' Prometheus Bound (Toronto 1980).

G. Crane, «Politics of consumption and generosity in the carpet scene of the Agamemnon»,CPh 88 (1993) $117-136$.

G. Devereux, Dreams in Greek tragedy (Oxford 1975).

A. D. Fitton-Brown, «Niobe», CQ (1954) 175- 180.

A. D. Fitton-Brown, «Prometheia», JHS 79 ( 1973) 52-60.

P. L. Furiani, «Le donne eschilee in guerra tra immaginario e realtà sociale», Euphrosyne 18 (1990) 9-22.

M. Gagarin, Aeschylean drama (Berkeley 1976).

Th. Gantz, «The chorus of Aischylos' Agamemnon», HSPh 87 (1983) 65-86.

A. Garzya, «Sui frammenti dei Mirmidoni di Eschilo», in De Homero a Libanio (Madrid 1995) 41 56.

J. Gould, «Hiketeia», JHS 93 (1973) 74-I03.

R. D. Griffith, «Disrobing in the Oresteia», CQ 38 (1988) 552-554.

E. Hall, Inventing the Barbarian. Greek self-definition through tragedy (Oxford 1989). 
Th. Harrison, The emptiness of Asia (London 2000).

F. Jouan, «La tétralogie des Danaides d'Eschyle.Violence et amour», Actes du Colloque Le théâtre grec antique: La tragédie (Paris 1998) II-25.

H. D. F. Kitto, Form and meaning in drama (London reimpr. 1959).

A. Lebeck, «The robe of Iphigenia in Agamemnon», GRBS 5 (1964) 35-4I.

A. Lebeck, The Oresteia (Cambridge, Massachusetts 197I).

A. Lesky, «Decision and responsibility in the tragedy of Aeschylus», in E. Segal, Greek tragedy (Oxford reimpr. 1991) 13-23.

E. Lévy, «Le théâtre et le rêve: le rêve dans le théâtre d'Eschyle», in Théatre et spectacles dans I'Antiquité (Leiden 1983) 141-168.

P. G. Maxwell-Stuart, «The appearance of Aeschylus' Erinyes», G\&R 20 (1973) 8I-84.

J. Mejer, «Recognizing what, when and why ? The recognition scene in Aeschylus' Choephori», in Arktouros. Hellenic Studies presented to B. M.W. Kitto (New York 1979) | I5-121.

A. Melero, «Notas a los Teoros de Esquilo», in De Homero a Libanio (Madrid 1995) 57-7l.

A. N. Michelini, Tradition and dramatic form in the Persians of Aeschylus (Leiden 1982).

A. Moreau, «La Clytemnestre d'Eschyle», Cahiers du Gita 8 (1994/5) |53-17|.

A. Moreau, «Le drame satyrique eschyléen est-il 'mauvais genre' ?», Cahiers du Gita 14 (200I) 39-62.

«Les Perses d'Eschyle», coord. P. Ghiron-Bistagne., A. Moreau, J. C. Turpin, Cahiers du Gita 7 (I992- 1993).

A.W. Pickard-Cambridge, «The Niobe of Aeschylus», in Greek Poetry and Life (Oxford 1936) 106$-120$.

Y. Prins, «The power of the speech act: Aeschylus' Furies and their binding song», Arethusa 24 (1991) 177-195.

M. O. Pulquério, Estrutura e função do diálogo lírico-epirremático em Ésquilo (Coimbra 1964).

R. Rehm, «The staging of suppliant plays», GRBS 29 (1988) 263-307.

174 J. de Romilly, L'évolution du pathétique d'Eschyle à Euripide (Paris 1961).

S. L. Schein, «The Cassandra scene in Aeschylus'Agamemnon», G\&R 29 (1982) I|-16.

D. S. Schenker, «The Queen and the Chorus in Aeschylus' Persae», Phoenix 48 (1994) 283-293.

B. Snell, «Aeschylos' Isthmiastai》, Hermes 84 (1956) I- I I.

M. Stieber, «Aeschylus' Theoroi and realism in Greek art», HSPh 124 (1994) 85-। 19.

D. F. Sutton, «A handlist of satyr plays», HSPh 78 (1974) 107-143.

D. F. Sutton, «Aeschylus' Thoeoroi or Isthmiastai: a reconsideration», GRBS 22 (I98I) 335-338. 
O.Taplin, «Aeschylean silences and silences in Aeschylus», HSPh 76 (1972) 57-97.

O. Taplin, Greek tragedy in action (Berkeley 1978).

O. Taplin, The stagecraft of Aeschylus (Oxford 1989).

W. G. Thalmann, Dramatic art in Aeschylus' Seven against Thebes (New Haven and London 1978).

W. G. Thalmann, «Xerxes' rags: some problems in Aeschylus' Persians», AJPh I0I (1980) 260-282.

Ch. Turner, «Perverted supplication and other inversions in Aeschylus' Danaid trilogy», Cl 97 (200I) 27-50.

R. G. Ussher, «The other Aeschylus», Phoenix 31 ( 1977) 287-299.

K.Valakas, «The first stasimon and the chorus in Aeschylus' Seven against Thebes», SIFC 86 (1993) 55-86.

P. Vicaire, «Pressentiments, présages et prophéties dans le théâtre d’Eschyle», REG 76 (|963) 337-357.

Ph. Yziquel, «Figures du sacrifice dans le théâtre d'Eschyle», Pallas 57 (200I) |53-167.

Ph. Yziquel, «Le drame satyrique eschyléen», Cahiers du Gita I4 (200 I) I-22.

M. L. West, «The Prometheus trilogy», JHS 99 (1979) |30-। 48. 
Investigação

Coimbra

Imprensa da Universidade

2005 